\title{
Série Educar Educação Especial e Inclusiva
}

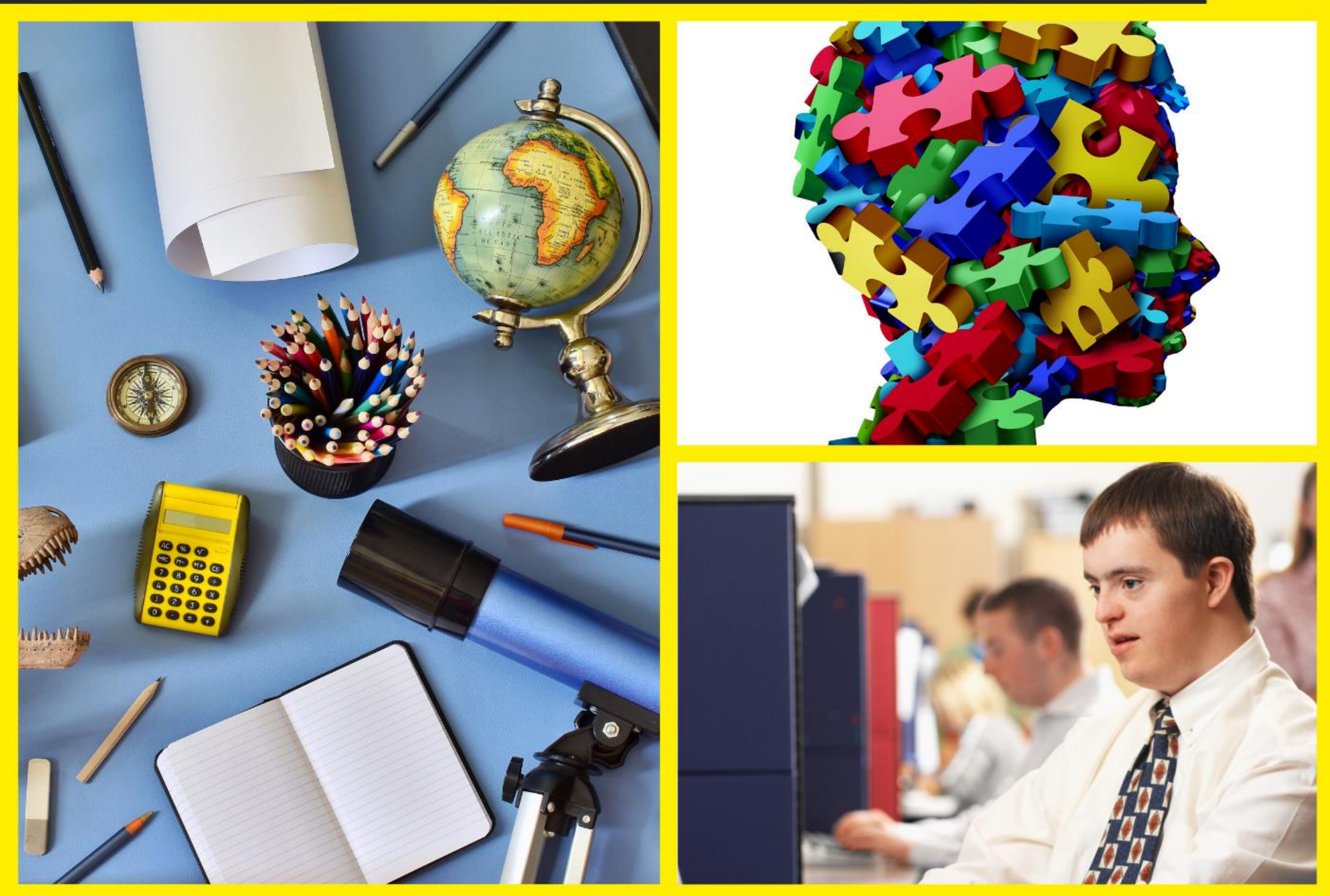

\ Editora Poisson

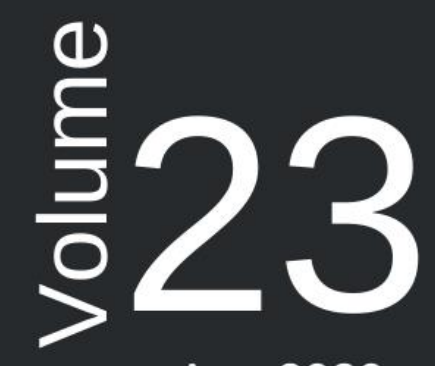


Editora Poisson

(organizadora)

\section{Série Educar - Volume 23 \\ Tecnologia}

1a Edição

Belo Horizonte

Poisson

2020 


\section{Editor Chefe: Dr. Darly Fernando Andrade}

\section{Conselho Editorial}

Dr. Antônio Artur de Souza - Universidade Federal de Minas Gerais

Ms. Davilson Eduardo Andrade

Dra. Elizângela de Jesus Oliveira - Universidade Federal do Amazonas

Msc. Fabiane dos Santos

Dr. José Eduardo Ferreira Lopes - Universidade Federal de Uberlândia

Dr. Otaviano Francisco Neves - Pontifícia Universidade Católica de Minas Gerais

Dr. Luiz Cláudio de Lima - Universidade FUMEC

Dr. Nelson Ferreira Filho - Faculdades Kennedy

Ms. Valdiney Alves de Oliveira - Universidade Federal de Uberlândia

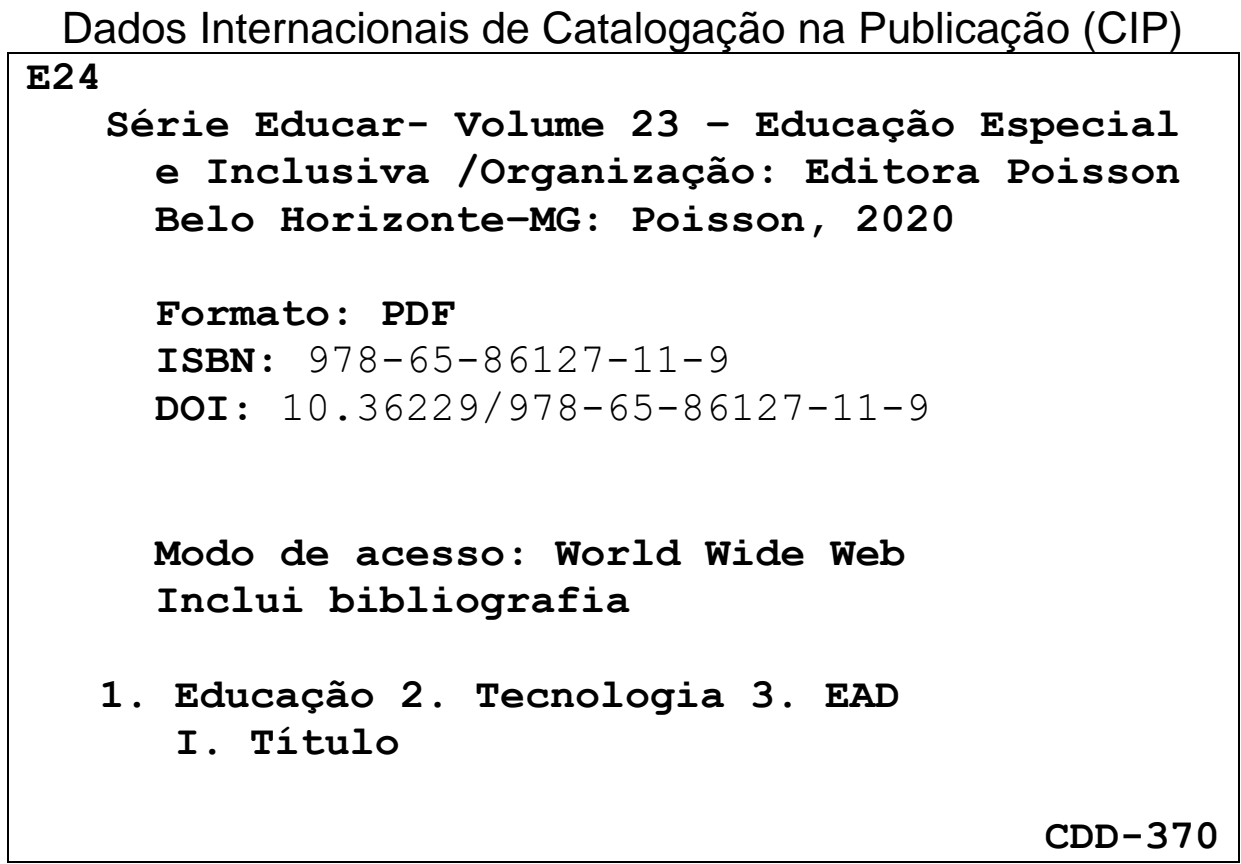

O conteúdo dos artigos e seus dados em sua forma, correção e confiabilidade são de responsabilidade exclusiva dos seus respectivos autores

$\underline{\text { www.poisson.com.br }}$

contato@poisson.com.br 


\section{SUMÁRIO}

Capítulo 1: Políticas públicas de educação inclusiva: Desafios à escolarização profissional do público-alvo da educação especial no IF Goiano - Campus Urutaí...... 07

Nahyme Zahia Amaral Mohana

DOI: 10.36229/978-65-86127-11-9.CAP.01

Capítulo 2: 0 olhar dos professores sobre a formação continuada na área da educação inclusiva 14

Ana Carolina Sales Oliveira, Cibele Moreira Monteiro

DOI: $10.36229 / 978-65-86127-11-9 . C A P .02$

Capítulo 3: Atuação do professor coordenador frente a educação especial na perspectiva inclusiva 20

Melina Rosa da Silveira Franco, Luci Pastor Manzoli, Caio Vinicius dos Santos, Evelin Oliveira de Rezende Piza, Neusa Aparecida Mendes

DOI: $10.36229 / 978-65-86127-11-9 . C A P .03$

Capítulo 4: Inclusão escolar na educação básica: A atuação da Psicologia 24

Anna Lúcia Sampaio Marchesini, Fernanda Vaz Torres

DOI: 10.36229/978-65-86127-11-9.CAP.04

Capítulo 5: Tecnologias digitais na atividade de inclusão na escola: Discussões em torno da fluência digital e segurança docente 33

Alaim Souza Neto, Maria Julia Pedroso, Nicoly Longaretti de Souza

DOI: 10.36229/978-65-86127-11-9.CAP.05

Capítulo 6: Relações educadores-educandos na educação de jovens e adultos: Aprendendo a "Pedagogia da autonomia" na Práxis 39

Ivani Soares

DOI: 10.36229/978-65-86127-11-9.CAP.06

Capítulo 7: Relato de experiência a inspiração freireana na EJA: Articulando o ético e o estético. 50

Luciane Maria Ribeiro da Cruz Santos

DOI: 10.36229/978-65-86127-11-9.CAP.07

Capítulo 8: Possibilidades da educação de jovens e adultos como espaço de afirmação sob a perspectiva do gênero. 55

Erlando da Silva Reses, Walace Roza Pinel, Lenilda Damasceno Perpétuo DOI: 10.36229/978-65-86127-11-9.CAP.08 


\section{SUMÁrio}

Capítulo 9: Inclusão nas instituições de ensino superior (IES) no Brasil 60

Suzana Arleno Souza Santos, Adriana Pires de Arezzo, Simone Garrido Esteves Cabral, Julio Cesar Mello D'Amato

DOI: 10.36229/978-65-86127-11-9.CAP.09

Capítulo 10: Implantação de políticas de ações afirmativas na Pós-Graduação do Instituto Federal do Espírito Santo

Gabriel Domingos Carvalho, Renata Gandra de Melo

DOI: $10.36229 / 978-65-86127-11-9 . C A P .10$

Capítulo 11: Educação especial: Inclusão Social e promoção de medidas de conscientização e combate à violência escolar 72

Fernanda Lima Ferreira, Dulce Barbosa Lins, Larissa Kelly dos Santos Silva, Ozinaldo Oliveira dos Santos DOI: $10.36229 / 978-65-86127-11-9 . C A P .11$

Capítulo 12: Relato de experiência: Intervenções de uma educadora física com jovem com paralisia cerebral 77

Priscila Figueiredo Brito de Azevedo, Francisca Maria Gomes Cabral Soares, Jordana Lorena Nogueira de Sousa

DOI: $10.36229 / 978-65-86127-11-9 . C A P .12$

Capítulo 13: Elementos da gamificação aplicados a objetos de aprendizagem para treinamento de crianças com TDAH .

Déverson Rogério Rando, Gabriela da Silva Sacchelli

DOI: $10.36229 / 978-65-86127-11-9 . C A P .13$

Capítulo 14: Educação especial e a importancia do diagnóstico multidisciplinar e da intervenção cognitiva 92

Rosemeire Quilante Azevedo, Angélica Biazus Mendonça da Fonseca, Marcos Magalhães Vasquez DOI: 10.36229/978-65-86127-11-9.CAP.14

Capítulo 15: A sala de atendimento educacional especializado-AEE no desenvolvimento dos alunos com deficiência. 101

Ana Paula Silva de Souza, Genilda Mendonça de Souza Araújo, Márcia Gomes dos Santos Silva, Mônica de Fátima Guedes de Oliveira

DOI: $10.36229 / 978-65-86127-11-9 . C A P .15$ 


\section{SUMÁRIO}

Capítulo 16: Deficiência intelectual e aprendizagem: Estudos sobre inclusão no município de Ipojuca. 109

Maria Rosemary de Brito, Edna Felix da Silva, Geany Carla Barros Silva, Kaltieli Gomes da Silva DOI: 10.36229/978-65-86127-11-9.CAP.16

Capítulo 17: Inclusão socioeducacional da pessoa com deficiência através da atividade física, do turismo social e de eventos socioculturais - um relato de experiência .......... 114

Izabeli Sales Matos, Artur José Braga de Mendonça

DOI: $10.36229 / 978-65-86127-11-9 . C A P .17$

Capítulo 18: 0 atendimento educacional especializado para cursos de nível médio técnico em uma instituição da rede federal de educação: Possibilidades rumo à institucionalização.

Cláudia Terra do Nascimento Paz, Cláudia Medianeira Alves Ziegler

DOI: 10.36229/978-65-86127-11-9.CAP.18

Capítulo 19: Ensino de ciências com a abordagem da química verde na educação inclusiva

Monique Gonçalves, Fábio Dias de Oliveira Junior DOI: 10.36229/978-65-86127-11-9.CAP.19

Autores: 


\section{Capítulo 1}

\section{Políticas públicas de educação inclusiva: Desafios à escolarização profissional do público-alvo da educação especial no IF Goiano - Campus Urutaí}

\section{Nahyme Zahia Amaral Mohana}

Resumo: Este artigo apresenta uma pesquisa sobre as ações afirmativas que visam a educação inclusiva e que estão sendo praticadas no Instituto Federal de Educação, Ciência Tecnologia Goiano - Campus Urutaí, e nesse cenário, conhecer as propostas para o público-alvo da Educação Especial na Educação Profissional Técnica de nível médio. Analisamos os Planos de Desenvolvimento Institucional (PDI - 2014/2019 e 2019/2023), observando as diretrizes e os objetivos do público-alvo da Educação Especial na Educação Profissional Técnica de nível médio e identificamos que nos documentos oficiais existentes sobre a inclusão do público-alvo da educação especial estão elencadas propostas de educação inclusiva visando uma educação igualitária e de qualidade, respeitando os limites de cada educando. Identificamos as ações políticopedagógicas previstas pelo IF Goiano para o atendimento do público-alvo da educação especial, conforme a legislação e dispositivos legais institucionais, considerando o que preconiza a legislação pertinente; e as intervenções político-pedagógicas desenvolvidas pelo Núcleo de Atendimento às Pessoas com Necessidades Específicas (NAPNE). Um estudo de cunho documental, onde foram analisados os PDIs do IF Goiano, legislações e políticas públicas que tratam da educação inclusiva. Acreditamos que este estudo possibilitou uma contribuição ímpar no sentido de analisar e promover questionamentos sobre as Políticas Educacionais inclusivas no âmbito da educação profissional tecnológica, desenvolvidas no Instituto Federal Goiano, proporcionando um mapeamento, ainda que sucinto, de ações afirmativas direcionadas ao público-alvo da educação inclusiva, identificando melhorias nessa modalidade de ensino pra que possamos alcançar a educação inclusiva tão almejada no cenário educacional brasileiro.

Palavras-Chave: Educação Especial. Educação Profissional. Teoria Crítica 


\section{INTRODUÇÃO}

As políticas públicas para a inclusão do público-alvo da educação especial são frutos de lutas e resistências, mas os resultados desejados ainda estão muito longe do alcançado. A educação inclusiva não surgiu para beneficiar um grupo que antes era segregado, excluído, discriminado e colocado à margem do sistema educacional como um todo. Inclusão significa que todos, sem exceção, têm direito à educação de qualidade socialmente referendada e a equiparação de oportunidades na sociedade.

A educação não é um produto pronto e acabado, não existe apenas para transmitir conhecimento e finalizar com certificados e diplomas. Educação é muito mais do que isso. É uma forma, uma conexão entre as pessoas que vai muito além do "estar em sala de aula", e deve obrigatoriamente ser acessível e oportunizar todos os indivíduos, sejam eles ditos "normais" ou não.

Quando nos reportamos para o campo da educação inclusiva, os cuidados se redobram, visto que requer uma atenção, dedicação, comprometimento e políticas públicas voltadas para o cumprimento do que preconiza as diversas leis inerentes a essa modalidade educacional, no sentido de proporcionar a todos uma educação de qualidade e de igualdade.

A escola como ponto de referência e criadora de oportunidades, tem a obrigação de proporcionar possibilidades de aprendizagem, visando formar cidadãos conscientes do potencial que cada um possui, independente das suas limitações, sejam elas físicas e/ou intelectuais.

Mantoan, afirma que

[...] a escola não pode continuar ignorando o que acontece ao seu redor, nem anulando e marginalizando as diferenças nos processos pelos quais forma e instrui seus alunos. E muito menos desconhecer que aprender implica ser capaz de expressar, dos mais variados modos, o que sabemos, implica representar o mundo a partir de nossas origens, de nossos valores e sentimentos. (MANTOAN, 2003, p.12).

Mais do que ofertar vagas a esses alunos com necessidades educativas especiais - $\mathrm{NEE}^{1}$, a escola tem a obrigação de praticar ações afirmativas visando o ingresso e permanência desses alunos no ambiente escolar, desmistificando a exclusão desses indivíduos do processo educacional, não apenas devido a barreiras arquitetônicas, porque as barreiras são na verdade, das mais diferentes ordens, sejam elas sociais, econômicas, religiosas e sociais.

A educação inclusiva ou educação especial como assim é denominada pela Lei de Diretrizes Básicas da Educação - LDB², define em seu artigo 58: "Entende-se por educação especial, para os efeitos desta Lei, a modalidade de educação escolar, oferecida preferencialmente na rede regular de ensino (grifo nosso), para educandos portadores de necessidades especiais" (BRASIL, 1996).

Percebemos também que a educação inclusiva não significa apenas inserir o educando dentro de uma sala regular de ensino. Ela precisa efetivar seu pleno convívio em sua comunidade, dentro e fora do ambiente escolar. Porque não é a deficiência que causa barreiras, mas ao contrário, as barreiras sociais, políticas, arquitetônicas, comportamentais, atitudinais e ideológicas é que limitam as pessoas. Por exemplo, uma pessoa com deficiência torna-se mais deficiente ainda quando ela não consegue exercer o seu direito de ir e vir sendo prejudicada sobremaneira na sua cidadania.

\footnotetext{
1 Conforme a Lei 12.796 de abril 2013, o termo NEE utilizado no decorrer do texto refere-se ao público alvo da Educação Especial, ou seja, às pessoas com deficiência, superdotadas/altas habilidades e com transtornos globais do desenvolvimento, as quais apresentam necessidades educativas especiais.

${ }^{2}$ Lei 9394/96 - Lei das Diretrizes e Bases da Educação, que estabelece as diretrizes e bases da educação nacional
} 
De acordo com Paul Hunt (1960 apud DINIZ 2007), numa perspectiva marxista, o deficiente é aquele que se torna aleijado dos processos sociais, e consequentemente educacionais, não em razão de sua limitação física, mas, sobretudo, em razão das "deficiências" da política e da sociedade, que admitem apenas a deficiência como um aspecto individual e não propriamente social. Nesse aspecto, pode-se inferir que o diferente nem sempre é visto com bons olhos e a luta da educação inclusiva ainda tem um longo caminho a trilhar. Assim, contrapondo-se a máxima de que ser normal é se encaixar em padrões pré-definidos, bordões como "ser diferente é ser normal" tentam trazer mudanças nas visões da política e da sociedade ao tratar a diferença como um direito social como colocado por Valdelúcia:

[...] ao lado do direito à igualdade, surge, também, como direito fundamental, o direito à diferença. 0 reconhecimento da diferença implica o reconhecimento da diversidade humana como um valor. (VALDELÚCIA, 2016)

Entretanto, nota-se avanços consideráveis, como a promulgação por órgãos competentes da educação de leis, decretos, resoluções, e outros, além de mobilizações de grupos de apoio, comunidades ocorridas principalmente por essa causa ter sido "abraçada” pelos docentes, protagonistas também desse cenário. No entanto, muita ainda se tem por fazer.

As demandas ocorrem de diversas áreas e níveis dentro do ambiente escolar e a tão sonhada educação inclusiva ainda assusta um pouco os docentes e outras profissionais ligados diretamente a essa realidade, que é um desafio a ser enfrentado, visto que a maioria das instituições de ensino ainda carecem de recursos multifuncionais, capacitação, infraestrutura física, apoio de equipe gestora, entre outros fatores essenciais à prática da inclusão.

A partir do Decreto n. 7.611/11, institui-se o Atendimento Educacional Especializado - $\mathrm{AEE}^{3}$, que vem para contribuir sobremaneira na inclusão desses alunos com necessidades educativas especiais, auxiliando os professores em sala de aula e, por conseguinte, atuando como um facilitador, promovendo condições de acesso, participação e aprendizagem desse aluno no ensino regular. Seu objetivo é eliminar as barreiras que possam obstruir o processo de escolarização de estudantes com deficiência, transtornos globais do desenvolvimento e altas habilidades ou superdotação. 0 especialista em AEE, na verdade, faz a ponte entre o aluno e o professor da sala de aula regular, possibilitando a esse aluno uma maior interação tanto educacional, social e por que não dizer, psicológica, visto que, o aluno percebe que não está sozinho, que esse profissional de AEE pode e deve auxiliar para que esse aluno possa ter uma educação de qualidade e igualitária, dentro das suas possibilidades e limites.

Observa-se que a formação de professores do AEE, é um aspecto que merece atenção por parte dos órgãos responsáveis, sendo o professor parte integrante desse processo e que irá mediar e proporcionar a esses alunos com necessidades educativas especiais, a oportunidade de fazer valer os seus direitos, alcançando uma educação igualitária, dentro dos limites de capacidade de cada indivíduo.

A Política Nacional de Educação Especial na Perspectiva da Educação Inclusiva (2008, p. 14), é bem clara quando preconiza seu principal objetivo:

A Política Nacional de Educação Especial na Perspectiva da Educação Inclusiva tem como objetivo assegurar a inclusão escolar de alunos com deficiência, transtornos globais do desenvolvimento e altas habilidades/superdotação, orientando os sistemas de ensino para garantir: acesso ao ensino regular, com participação, aprendizagem e continuidade nos níveis mais elevados do ensino; transversalidade da modalidade de educação especial desde a educação infantil até a educação superior; oferta do atendimento educacional especializado; formação de professores para o atendimento educacional especializado e demais profissionais da educação para a inclusão; participação da família e da comunidade; acessibilidade arquitetônica, nos transportes, nos mobiliários, nas comunicações e informação; e articulação intersetorial na implementação das políticas públicas. (BRASIL, 2008)

Nesse contexto, a Educação Profissional, como modalidade de ensino da Educação Básica e educação para o trabalho, vem ao encontro da Política Nacional de Educação Especial na Perspectiva da Educação Inclusiva sendo de extrema relevância para o progresso social e humano, pois traz a possibilidade de a

\footnotetext{
${ }^{3}$ Atendimento Educacional Especializado, instituído pelo Decreto n. 7.611, de 17 de novembro de 2011, que dispõe sobre a educação especial, o atendimento educacional especializado e dá outras providências.
} 
pessoa se sentir útil, se sentir capaz, sentir que suas limitações não a impedem de realizar sonhos, de crescer profissionalmente, de fazer parte realmente da sociedade. Dessa forma, a Educação Profissional, por ser uma educação socialmente organizada para o mercado de trabalho recebe mais intensamente a influência dos fatores econômicos e sociais.

Nesse contexto da educação inclusiva e sua relação com a educação profissional, esta pesquisa vem tratar das ações afirmativas praticadas no Instituto Federal de Educação, Ciência Tecnologia Goiano - Campus Urutaí, e nesse cenário, conhecer as propostas para o público-alvo da Educação Especial na Educação Profissional Técnica de nível médio.

O lócus deste estudo, Campus Urutaí, fica localizado na cidade de Urutaí- Goiás, distante cerca de 160 Km da capital Goiânia. Considerando os últimos dez anos, segundo a Lei no 11.892/20084, a partir da criação dos Institutos Federais de Educação, Ciência e Tecnologia, até os dias atuais, pesquisamos os documentos oficiais e as ações afirmativas do Núcleo de Atendimento às Pessoas com Necessidades Específicas NAPNE desse Instituto e do Campus, a fim de conhecer e identificar as propostas de educação inclusiva materializadas nestes e as ações que melhor promovam o desenvolvimento em suas múltiplas dimensões, dos indivíduos com deficiência, considerando o que preconiza a legislação vigente.

A importância e desempenho do NAPNE no Campus Urutaí, numa tratativa de demonstrar as ações desenvolvidas por este Núcleo e conhecer se o mesmo está cumprindo a sua finalidade e implementando políticas que atendam esse público-alvo, protagonista dessa pesquisa.

Este estudo visa contribuir e promover questionamentos através de uma análise sobre as Políticas Educacionais Inclusivas no âmbito da educação profissional tecnológica, desenvolvidas no campus Urutaí do Instituto Federal Goiano, proporcionando um mapeamento de ações afirmativas direcionadas ao público-alvo da educação inclusiva, além de suscitar propostas visando uma melhoria nessa modalidade de ensino pra que possamos alcançar a educação inclusiva tão almejada no cenário educacional brasileiro.

Segundo Damasceno (2010, p. 162), para que a educação inclusiva aconteça de fato, faz necessário que um conjunto de ações sejam executadas, considerando a heterogeneidade de práticas de ensino:

Quando afirma a necessidade de se pensar e identificar as melhores práticas administrativas e pedagógicas para a inclusão escolar, significa que se rompe com um ideal totalitário e hegemônico de uma única pratica que dê conta das demandas dos estudantes. Ou seja, assumir o pluralismo pedagógico e educacional como proposta de trabalho significa o reconhecimento da diversidade, o respeito às diferenças e a criação de condições de oportunidades para todos. (DAMASCENO, 2010, p. 162)

Uma das premissas dos Institutos Federais é a educação profissional técnica de médio, possibilitando aos educandos egressos do ensino fundamental, um ensino de qualidade, o aprendizado de uma profissão, uma maior competitividade no mercado de trabalho e principalmente a formação de indivíduos conscientes da sua importância como seres humanos, parte da sociedade como um todo.

O IF Goiano, segundo o seu PDI 2014-2018, visa oferecer uma educação profissional técnica de nível médio sob a orientação da legislação vigente e atendendo aos princípios norteadores estabelecidos pela resolução CNE/CEB no 06/12, praticando a política de inclusão, conforme descreve no item 3.4.1.1.2:

$[\ldots]$

X - reconhecimento dos sujeitos e suas diversidades, considerando, entre outras, as pessoas portadoras de deficiência, transtornos globais do desenvolvimento e altas habilidades, além de pessoas em regime de acolhimento ou internação, e em regime de privação da liberdade.

O IF Goiano é uma autarquia federal detentora de autonomia administrativa, patrimonial, financeira, didático-pedagógica e disciplina, equiparado às universidades federais. Oferece educação superior, básica e profissional, pluricurricular e multicampi, especializada em educação profissional e tecnológica nas diferentes modalidades de ensino (PDI 2014/2018). Atende atualmente mais de 20.000 alunos de diversas cidades goianas e até de outros estados.

\footnotetext{
${ }^{4}$ Lei no 11.892, de 29 de dezembro de 2008 que institui a Rede Federal de Educação Profissional, Científica e Tecnológica, cria os Institutos Federais de Educação, Ciência e Tecnologia, e dá outras providências.
} 
O título deste trabalho suscita questionamentos à cerca do que está sendo feito de fato para promover a educação especial/inclusiva no IF e denota de forma contundente que o desafio à escolarização profissional desse público-alvo requer uma atenção permanente por parte dos gestores da Instituição, no sentido de implantar políticas e ações afirmativas que visem o ingresso, a permanência e formação desses profissionais, ao optarem pela educação profissional tecnológica.

A preocupação para com o atendimento das pessoas com NEE nos IFs é ainda recente e observamos que essa demanda foi surgindo com a chegada de pessoas com deficiência a essas instituições de ensino.

0 Núcleo de Atendimento às Pessoas com Necessidades Especiais (NAPNE), tem como missão nas instituições de ensino, articular ações que visem garantir a acessibilidade dessas pessoas, e ao desenvolvimento de uma cultura de respeito à diversidade e eliminação de barreiras, com o intuito de atingir o sucesso em sua formação profissional.

Destacar a importância de se desenvolver ações que melhor promovam o desenvolvimento, em suas múltiplas dimensões, dos indivíduos com deficiências, e não esquecendo que a inclusão educacional/escolar é uma realidade que precisa ser problematizada no âmbito acadêmico, visando a ampliação do conhecimento teórico/prático em sua relação com as políticas públicas.

A pretensão é que este estudo ao final, traga contribuições para o planejamento e para implementação de futuras políticas públicas na área da educação profissional inclusiva, na rede federal de ensino, especificamente o IF Goiano.

Nesse contexto, é indiscutível a importância da educação inclusiva que visa o atendimento desse públicoalvo. Entretanto muitas dúvidas ainda nos incomodam: os alunos com necessidades educativas especiais estão sendo atendidos de forma satisfatória? As diretrizes e normativas educacionais que regem a educação inclusiva estão sendo respeitadas e obedecidas no Instituto Federal Goiano? 0 que se apresenta de políticas afirmativas no Instituto Federal Goiano, que está contribuindo para que esses educandos tenham acesso à uma educação de qualidade e igualitária no ensino regular? O NAPNE está cumprindo com o seu papel de articulador e implementador das políticas de inclusão no IF Goiano - Campus Urutaí?

\section{OBJETIVOS}

- Avaliar as ações político-pedagógicas previstas pelo IF Goiano - Campus Urutaí, para o atendimento do público-alvo da Educação especial, conforme a legislação e dispositivos legais institucionais;

- Avaliar os impactos das intervenções político-pedagógicas desenvolvidas pelo NAPNE do Campus Urutaí no atendimento ao público-alvo da Educação especial por intermédio de suas ações afirmativas.

\section{METODOLOGIA}

Este estudo consiste numa pesquisa qualitativa, de cunho documental e que abordará como temática central as ações afirmativas desenvolvidas no IF Goiano - Campus Urutaí, buscando identificar e conhecer os conceitos e práticas introduzidos no âmbito da educação das pessoas com necessidades educativas especiais, e identificar se essas ações afirmativas que buscam legitimar o que preconiza a legislação referente aos direitos das pessoas com deficiência estão sendo cumpridas e se o NAPNE existente no Campus está efetivamente cumprindo esses documentos oficiais.

Como mola propulsora desta pesquisa, utilizaremos como suporte teórico-metodológico a Teoria Crítica, quando esta se reporta à ênfase na análise das condições de regulação social, desigualdade e poder.

Mazzotti, afirma que: a abordagem crítica é essencialmente relacional, ou seja, procura-se investigar o que ocorre nos grupos e instituições relacionando as ações humanas com a cultura e as estruturas sociais e políticas, tentando compreender como as redes de poder são produzidas, mediadas e transformadas. Parte-se do pressuposto de que nenhum processo social pode ser compreendido de forma isolada, como uma instância neutra acima dos conflitos ideológicos da sociedade. (MAZZOTTI, 1998, pg. 139)

Dessa maneira, este estudo pretende investigar o que realmente tem sido feito no âmbito da educação profissional técnica de nível médio para incluir as pessoas com deficiência, no Instituto Federal Goiano, particularmente no Campus Urutaí, e considerando que o suporte documental é extenso, e que talvez as ações afirmativas não correspondem ao respaldo que a legislação preconiza, suscitando questionamentos nesta pesquisadora, conforme destaca Carspecken e Apple, 1992 (In: MAZZOTTI, 1998, p.139). 
A diferença básica entre a teoria crítica e as demais abordagens qualitativas está, portanto, na motivação política dos pesquisadores e nas questões sobre desigualdade e dominação que, em consequência, permeiam seus trabalhos.

Essa pesquisa parte da premissa de que a inclusão do aluno com deficiência na escola comum é uma realidade que precisa ser respeitada e problematizada no âmbito acadêmico, pois, se tivermos o conhecimento teórico/prático interligado com as políticas públicas e com a realidade escolar, poderemos ter subsídios para intermediar ações coerentes com os anseios e necessidades dos sujeitos envolvidos.

Mazzotta (2000, p. 100), contextualiza a importância da escola quando diz:

Sendo um espaço público de capital importância na construção da cidadania, para cumprir essa função, a escola tem de ser organizada de modo que atenda a diversidade dos educandos, configurando-se como uma instituição social aberta e destinada a todos, com sentido integrador ou inclusivo (MAZZOTTA 2000, p. 100).

\section{RESULTADOS}

O Campus Urutaí, possui atualmente de acordo com a Plataforma Nilo Peçanha/2019 2.377 alunos matriculados e distribuídos nos cursos Técnicos, Superiores e Pós-graduações. De acordo com os dados disponibilizadas pelo NAPNE deste Campus, são atendidos 17 alunos com necessidades educacionais específicas variadas (física, deficiência intelectual, Auditiva, Visual, Múltipla ${ }^{5}$ ), TDAH6 ${ }^{6}$, Diabetes.

Segundo ainda estas informações, o Campus oferece, além do atendimento educacional especializado, um trabalho de parceria junto aos docentes visando a prática da educação inclusiva, possibilitando a esses educandos sua efetiva participação na sociedade, respeitando as particularidades da deficiência de cada um.

É evidente a importância do atendimento educacional especializado (AEE), que tem por finalidade principal identificar, elaborar e organizar recursos pedagógicos e de acessibilidade a fim de que as barreiras sejam eliminadas para que estes educandos com deficiência possam efetivamente participarem, observando e respeitando as limitações de cada um e considerando suas necessidades específicas. Esse atendimento surgiu na verdade para complementar os ensinamentos vistos nas salas de aula regular, funcionando como um apoio propulsor de resultados.

$\mathrm{Na}$ instituição estudada, percebe-se uma preocupação em atender às demandas requeridas pelos educandos com necessidades educacionais especiais preconizando a legislação e políticas públicas nacionais. À vista disso, encontramos várias resoluções internas, documentos oficiais, regimentos que tentam viabilizar o ingresso, a acessibilidade e permanência de alunos com necessidades educacionais especiais. A partir deste breve estudo e das informações disponibilizadas pelo NAPNE, podemos perceber que o IF Goiano - Campus Urutaí está desenvolvendo e praticando a educação inclusiva possibilitando ao público - alvo dessa modalidade condições de aprendizagem, disponibilizando atendimento educacional especializado, adaptações curriculares, estratégias de avaliação, horários flexibilizados de atendimento, uso de equipamentos extras, como notebooks, professores de Libras, atendimento psicológico, confecção de materiais pedagógicos. Ainda há muito que se fazer e avançar, entretanto, os profissionais do campus mostram-se extremamente comprometidos e isso com certeza nos traz um certo alívio ao perceber o compromisso dos profissionais.

\section{CONCLUSÕES}

Se compararmos o quantitativo de matrículas neste campus, com o número de matriculados com NEE, identificamos que o percentual de alunos com necessidades educacionais especiais ainda é pouco expressivo, ou seja, cerca de $0,7 \%$ do total. Este fato pode estar relacionado às dificuldades nas condições de acesso e permanência desta população nessas instituições, visto que só podem ingressar através de exame seletivo. É evidente que há a necessidade de medidas para modificar as estruturas das escolas, implantar serviços de apoio, redefinir questões curriculares, rever o processo de avaliação, proporcionar formação docente, sendo que para isso, é necessário o envolvimento de toda a comunidade escolar no

\footnotetext{
5 Deficiência Múltipla (paralisia cerebral, perda auditiva bilateral profunda)

6 TDAH - transtorno do déficit de atenção e hiperatividade
} 
projeto pedagógico da escola. Importante e fundamental eliminar atitudes preconceituosas, adequar programas, oferecer suporte pedagógico, criar orçamentos para os núcleos e ainda capacitar continuamente todos os profissionais que nela atuam.

Percebemos também que quando nos reportamos à legislação de educação inclusiva, constatamos que nosso pais está "muito bem servido" no que concerne a este assunto em pauta. Entretanto, o que se configura como precariedade é a prática dessas legislações, procurando não transferir essa responsabilidade apenas ao poder público. Cabe à cada um de nós desenvolver um compromisso individual, mas com um pensamento coletivo.

Ademais, e de forma ainda que superficial, o encaminhamento para o mercado de trabalho, ainda se faz de maneira muito tímida e insuficiente, verificando-se que algumas poucas instituições fazem o controle deste dado e a falta desse tipo de indicador impede que uma avaliação mais adequada sobre a efetividade do programa seja efetuada. Conclui-se, portanto, que não basta apenas a adoção de medidas isoladas para criação de oportunidades de acesso nas instituições federais, se não for acompanhada da parceria de outras áreas, como, Reabilitação, Saúde e do Transporte, visando permitir o acesso e a permanência dessas pessoas nessas instituições. Assim, faz-se necessário um maior planejamento, acompanhamento e avaliação da implementação dessas ações afirmativas propostas pela Instituição de Ensino, envolvendo docentes, administrativos, discentes, autoridades governamentais e toda a comunidade.

\section{REFERÊNCIAS}

[1] Brasil. Ministério da Educação. Lei 9394. Diretrizes e Bases da Educação Nacional. Brasília, 1996.

[2] _ Ministério da Educação. Política Nacional de Educação Especial na Perspectiva da Educação Inclusiva (MEC, 2008). Disponível em: http://portal.mec.gov.br/arquivos/pdf/politicaeducespecial.pdf. Acesso em: 18 mai. 2019.

[3] . Lei Federal no 11.892, de 29 de dezembro de 2008. Institui a Rede Federal de Educação Profissional, Ciência e Tecnológica, cria os Institutos Federais de Educação, Ciência e Tecnologia. Brasília, 2008b.

[4] _. Decreto no. 7.611, de 17 de novembro de 2011. Dispõe sobre o atendimento educacional especializado, revoga o Decreto 6.571 de 17 de setembro de 2008. Diário Oficial da União. Brasília, 2011.

[5] _ Resolução Cne/Ceb n. 6 de 20 de setembro de 2012. Define Diretrizes Curriculares Nacionais para a Educação Profissional Técnica de Nível Médio. Disponível em: portal.mec.gov.br. Acesso em: 18 abr. 2019.

[6] Alves Mazzotti, Alda Judith, Gewandsznajder, Fernando. 0 método nas Ciências naturais e Sociais: pesquisa quantitativa e qualitativa. São Paulo: Pioneira, 1998. p. 139.

[7] Damasceno, Allan Rocha. Educação Inclusiva e organização da escola: Projeto pedagógico na perspectiva da Teoria Crítica. Tese de Doutorado apresentada ao Programa de Pós-Graduação em Educação, Universidade Federal Fluminense, 2010.

[8] Diniz, Débora. O que é deficiência. São Paulo: Editora Brasiliense;2007. (Coleção Primeiros Passos).

[9] Mantoan, Maria Teresa Égler. Inclusão escolar: o que é? Por quê? Como fazer? São Paulo: Moderna, 2003. pag.12

[10] Mazzotta, M.; Sousa, S. Inclusão escolar e educação especial: considerações Sobre a política educacional brasileira. Estilos da Clínica. Revista sobre a infância com problemas. v. 5, n. 9, p. 96-108, 1 dez.2000. Disponível em: https://www.revistas.usp.br/estic/issue/view/4997. Acesso em: 16 mai. 2019

[11] Plano de Desenvolvimento Institucional (PDI). Instituto Federal de Educação, Ciência e Tecnologia Goiano IF Goiano- Goiânia- GO, 2010.

[12] Plano de Desenvolvimento Institucional (PDI). Instituto Federal de Educação, Ciência e Tecnologia Goiano IF Goiano- Goiânia- GO, 2014.

[13] Plataforma Nilo Peçanha. www.plataformanilopecanha.org?\#/login.2019. Disponível em: http://resultados.plataformanilopecanha.org/2019/. Acesso em: 20 de mai. 2019.

[14] Regimento Geral do IF Goiano. Disponível em: www.ifgoiano.edu.br. Acesso em 10 maio. 2019.

[15] Souza Leme, Erika; Alves da Costa, Valdelúcia. Educação, Inclusão e direitos humanos: como esse estuário desaguou na escola? Revista Educação especial, vol. 29, núm. 56, set-dez, 2016, pp 667-679. UFSM, Santa Maria. 


\section{Capítulo 2}

\section{O olhar dos professores sobre a formação continuada na área da educação inclusiva}

\section{Ana Carolina Sales Oliveira \\ Cibele Moreira Monteiro}

RESUMO: A educação inclusiva no brasil ainda se caracteriza como um projeto em construção, embora seus fundamentos já estejam presentes na constituição federal de 1988. Um dos fatores necessários para a consolidação da educação especial na perspectiva inclusiva é a melhoria do processo de formação de professores. Devido a isso desenvolvemos uma pesquisa com o objetivo de analisar o discurso de professores a respeito dos cursos de formação continuada nessa área. Realizamos a análise com base nos pressupostos teóricos da análise do discurso, principalmente nos estudos de pêcheux e de orlandi, e nos fundamentos da sociologia apresentados por bourdieu. Coletamos os dados por meio de dois questionários aplicados durante uma oficina desenvolvida para professores da educação básica em parceria com a superintendência regional de ensino de pouso alegre - $\mathrm{mg}$. Como resultado, observamos que a maioria dos professores acredita que os cursos de formação continuada devam apresentar práticas prontas que possam ser repetidas mecanicamente no processo de ensino e aprendizagem de diferentes alunos com necessidades educacionais especiais. Verificamos ainda que os professores que têm consciência de que não existem "fórmulas prontas" para o sucesso da educação especial na perspectiva inclusiva acreditam que a devoção e o amor à profissão são os principais fatores responsáveis pelo progresso dos alunos. Concluímos que a maior parte dos professores não vê os cursos de formação como espaço de reflexão.

Palavras-Chave: Educação inclusiva, formação continuada, discurso do professor. 


\section{INTRODUÇÃO}

A educação inclusiva no Brasil ainda se caracteriza como um projeto em construção, com acertos e erros, com avanços, estagnações e, às vezes, até retrocessos. A Constituição Federal do Brasil de 1988, ao determinar que a educação "é direito de todos" e que deve ser garantida "igualdade de condições para o acesso e permanência na escola" (BRASIL, 1988), propõe a integração escolar de todos os alunos. A partir dessa proposta, outras surgiram prevendo a substituição da integração pela inclusão escolar. Leis, decretos, resoluções, portarias e pareceres foram publicados a fim de determinar ações necessárias para que as escolas do país se tornassem inclusivas.

Nesse processo, destaca-se a inclusão de pessoas com deficiência, que constitui o foco de diversos documentos legais publicados nas últimas décadas. É importante realçar que a mudança do olhar em relação aos indivíduos com deficiência e a consequente luta pela ampliação de seus direitos são observadas não apenas na área da educação, mas também em diversos outros setores da sociedade. A Lei Brasileira de Inclusão da Pessoa com Deficiência pode ser vista como uma importante conquista, fruto de determinações legais anteriores e de esforços empreendidos em diferentes áreas para que a igualdade de direitos prevista na Constituição Federal de 1988 se torne realidade.

No capítulo intitulado "Do direito à educação", a Lei Brasileira de Inclusão da Pessoa com Deficiência determina que

a educação constitui direito da pessoa com deficiência, assegurados sistema educacional inclusivo em todos os níveis e aprendizado ao longo de toda a vida, de forma a alcançar o máximo desenvolvimento possível de seus talentos e habilidades físicas, sensoriais, intelectuais e sociais, segundo suas características, interesses e necessidades de aprendizagem. (Brasil, 2015).

Embora a legislação brasileira revele avanços significativos, ainda há muitos obstáculos que dificultam a consolidação da educação especial na perspectiva da educação inclusiva no país. Um dos principais fatores capazes de contribuir para a superação desses obstáculos é a melhoria do processo de formação docente. Em virtude disso desenvolvemos uma pesquisa com o objetivo de analisar o discurso de professores a respeito dos cursos de formação continuada na área da educação especial na perspectiva inclusiva.

A educação de pessoas com deficiência é tomada como temática de diversos estudos acadêmicos e científicos. Haja vista o grande número de publicações disponíveis em livrarias, ambientes virtuais acadêmicos, entre outros, e o crescente número de documentos legislativos e regimentais para a prática da educação inclusiva, compreendemos que a problemática se apresenta pertinente e impreterível. Esta tem se apresentado por meio, por exemplo, de discussões que emergem ao longo de encontros entre professores e aqueles que se propõem a levantar outras propostas de atuação educacional nas salas de aula regulares brasileiras.

A educação da pessoa com deficiência tem sido alvo de estudos e discussões que levaram ao desenvolvimento de políticas orientadoras para a inserção desse aluno no ensino regular. Entretanto, isso tem sido feito sem as providências necessárias para um preparo adequado dos professores, forçandoos a trabalhar com as noções de normalidade e desvio, a partir apenas do senso comum. (Musis; Carvalho, 2010, p. 203, grifo nosso).

Com vistas a atender essa necessidade de "preparo", "[...] a Análise do Discurso nos demanda um olhar sempre sensível à diferença constitutiva das relações sociais, o que significa buscar compreender o social em suas tensões, que a ordem urbana tenta continuamente administrar" (Lagazzi, 2010, p. 75). Nesse campo de relações entre sujeito, linguagem e sociedade, postas em movimento nos discursos do sujeitoprofessor, que tem sua prática profissional orientada e disciplinada pelos discursos do Estado, é que operaremos.

Realçamos que, a partir da perspectiva da Análise de Discurso, o sujeito é sempre interpelado pela ideologia e estará afetado por uma exterioridade - a história, a memória, o político - que lhe será constitutiva (Pêcheux, 1997). "A ideologia, como sabemos, na perspectiva discursiva, é uma prática e esta prática envolve, afeta e faz parte do processo de significação do corpo do sujeito" (ORLANDI, 2012, p. 87), estabelecendo posições, mais ou menos rígidas, nos processos de interação dos sujeitos com a materialidade de seus corpos. 
Interessa explicar que é sobre a discursivização a respeito dos cursos de formação docente relacionados à inclusão de alunos com deficiência que direcionamos os nossos gestos de interpretação. Nós nos colocamos, neste momento, a compreender a escola como uma instituição histórica, afetada pelo político, que produz suas práxis sob os sentidos de uma sociedade jurídico- capitalista, sendo afetada também por conflitos de interesses de grupos de poder que marcam a sociedade. Para isso, levamos em consideração que o capitalismo tem uma lógica própria que consiste na articulação entre os mecanismos de fora para dentro, ou seja, a política interfere na sociedade e essa, na escola.

Assim, ao olharmos para os discursos que se compõem no interior da escola devemos perceber os mecanismos de reprodução da ordem simbólica, que se manifestam nos discursos sobre a escola e o deficiente inserido em seu contexto. 0 espaço escolar deixa ver estruturas discursivas que hierarquizam, individualizam o corpo do sujeito e lhe atribuiem significados. "Enquanto corpo simbólico, corpo de um sujeito, ele é produzido em um processo que é um processo de significação, onde trabalha a ideologia, cuja materialidade específica é o discurso" (Orlandi, 2012, p. 85), sendo atribuído à instituição escolar, pela sociedade capitalista, o dever de "cuidar", "socializar" e "educar" o indivíduo e seu corpo nesses processos de subjetivação.

Para Bourdieu (2006), a escola, embora não deva, ignora as diferenças socioculturais, privilegiando em sua teoria e em sua prática as manifestações e os valores culturais das classes dominantes, favorecendo os alunos que já dominam esse aparato cultural. Assim, a escola, para esses alunos, é considerada uma continuidade da família e da sua prática social, enquanto os alunos das classes trabalhadoras precisam apropriar-se da concepção de mundo dominante. Com as pessoas com deficiência acontece o mesmo processo de assimilação, uma vez que as escolas, em sua maioria, não estão preparadas para recebê-las. Isso não deveria acontecer em um espaço primordial de socialização do sujeito, posto que as escolas, juntamente com a família, são responsáveis e encarregadas por desenvolverem a criança social e culturalmente. E se a lei diz que a "escola é para todos", cabe a ela estar pronta para receber todos os alunos.

\section{METODOLOGIA}

O material analisado com base nos fundamentos da Análise de Discurso e da Sociologia constituiu-se de respostas obtidas por meio de um questionário aplicado no início de uma oficina desenvolvida com professores da rede estadual que atuam em uma cidade do Sul de Minas Gerais. O objetivo dessa oficina foi discutir e promover, junto aos professores da educação básica, reflexões que interpelassem teórica e intervencionalmente a elaboração de práticas docentes inclusivas que considerassem os alunos com deficiência.

A oficina foi realizada em três dias diferentes. No primeiro dia aplicamos um questionário a fim de fazermos um mapeamento dos professores participantes, de sua experiência com a inclusão de alunos com deficiência e de suas expectativas em relação à formação nessa área. No último dia aplicamos outro questionário para que os professores pudessem deixar a sua impressão em relação à oficina. Neste trabalho analisamos respostas apresentadas no primeiro questionário.

\section{RESULTADOS E DISCUSSÃO}

Observamos, durante a análise dos questionários respondidos, que há, por parte dos professores, um movimento de reivindicação e de dependência dos cursos de capacitação ou treinamento ofertados pelo Estado. As falas apresentadas pelos professores ao serem indagados sobre "Que tipo de formação continuada você acredita que poderia contribuir para a sua prática?" podem ser sintetizadas nas respostas transcritas a seguir:

Cursos de atualização e capacitação. Muito estudo e leituras relacionadas. Orientações sobre como agir em determinada situação.

Através de cursos com aulas práticas para que os docentes entendam melhor todo esse processo de construção cognitiva em suas dificuldades.

Mais cursos a respeito das práticas em sala de aula para atender diversas deficiências.

Cursos sobre isso. Alguém para explicar o que deverá ser feito. 
Diversos cursos de capacitação, mas cursos que não sejam tão voltados somente a teorias mas para a prática como um fator indispensável.

Cursos, capacitações com práticas, trocas de experiências. Oficinas de práticas e troca de experiências. (grifo nosso)

Ao olharmos para o conjunto de falas de sequências discursivas das respostas dos professores, observamos o grande número de ocorrência dos termos "prática" e "capacitação". A recorrência desses termos nos mobiliza no sentido de interpretar essas falas no contexto geral da lógica capitalista de organização do Estado e das relações de troca e consumo, uma vez que "[...] com a capacitação, o treinamento, ele [o trabalhador] é um eterno repetidor" (Orlandi, 2014, p. 162).

A repetição dos discursos que reivindicam treinamentos ou capacitações práticas nos chamou a atenção e nos mobilizou para a realização de um gesto analítico que permitisse a compreensão da formação discursiva que sustenta, provavelmente, essa formulação. Observamos a contradição entre a imagem que os professores fazem de si mesmos, educadores, e as reivindicações por treinamentos ou capacitações práticas, para atender a demandas que, provavelmente, decorrem dos sentidos que atravessam a produção de uma imagem a respeito do que seria um professor e do que se espera de um professor em sala de aula.

Ao mesmo tempo em que os professores buscam se filiar ao sentido de "educadores" para se identificarem e comporem sua posição-sujeito profissional professor, é uma regularidade a reivindicação de treinamentos pontuais que os habilitariam ao trabalho de ensinar. Os sentidos que se produzem nesse campo de significação no entorno de uma formação discursiva cuja formação ideológica identifica o sujeito-professor no estereótipo de cuidador impingem ao sujeito a interpretação sobre a existência de uma dualidade entre ser professor e ser professor capacitado. Nessa direção, o sujeito rende-se ao discurso de capacitação prática para o trabalho sob a égide do modelo capitalista - a produtivista.

Bourdieu (2014, p. 251) observa que “[...] os dominantes em geral são silenciosos, não têm filosofia, não têm discurso; começam a tê-los quando nós os importunamos, quando interpelamos: por que vocês são como são?", obrigando-os a se posicionarem, a assumirem os discursos que buscam esconder atrás da ideia do "isso é obvio" (Bourdieu, 2014, p. 251). Ao interpelar o óbvio, o sujeito precisa estar fundamentalmente ancorado na língua e ter conhecimento de sua estrutura e de seu funcionamento. Orlandi (2014) afirma que, sem essa ancoragem e sem um bom conhecimento sobre a estrutura da língua, o sujeito não consegue se libertar dos discursos homogeneizadores.

É esse embasamento que nos permite afirmar que

educar não é capacitar, nem treinar, nem informar, mas dar condições para que, em seu modo de individuação, pelo Estado, o sujeito tenha a formação (conhecimento/saber) necessária para poder constituir-se em uma posição sujeito que possa discernir, e reconhecer, os efeitos de sua prática na formação social de que faz parte. (Orlandi, 2014, p. 167).

É preciso que o docente tenha uma sólida formação, não somente em sua habilitação específica, mas na própria língua que dá suporte a todos os discursos, de forma a "constituir-se em sua posição sujeito" e interpelar os discursos limitantes de sua atuação docente. Outro efeito de se colocar na dependência dos cursos de capacitação ou treinamento ofertados pelo Estado é o de fazer parecer que o professor sempre estará em uma posição de incompletude, de estar em falta.

A incompletude do saber e o estar em falta com o atendimento às demandas propostas pelo sistema educacional a serviço do Estado fazem com que o professor acredite que todas as mazelas do sistema sejam de sua responsabilidade. Ao se responsabilizar pelo sucesso da educação e, ao mesmo tempo, não se sentir capacitado para garantir a aprendizagem dos alunos com deficiência, o professor acredita que "é necessário haver amor à causa", conforme resposta apresentada por uma das professoras à seguinte pergunta: "Há algum outro apontamento que você gostaria de acrescentar neste questionário?".

Ao nos debruçarmos sobre essa resposta, fomos remetidos inicialmente às filiações ideológicas do campo da literatura, mais precisamente ao clássico de Miguel de Cervantes (1547-1616), Dom Quixote (1605). Nesse clássico, o personagem principal, inebriado pelos romances de cavalaria, lança-se à causa de defender os valores tradicionais de uma sociedade idealizada, baseada na nobreza e justiça das ações e oposição aos interesses mais imediatos e comezinhos da sociedade da época.

O que move Dom Quixote é o amor a uma causa, que o leva a viver um mundo paralelo, onde sua sanidade mental é posta à prova. Aos olhos alheios, o "Cavaleiro de Triste Figura" é alguém que vive defendendo 
estruturas sociais em decadência, destinado ao fracasso, um "peixe fora d'água", fora do "páreo". Ao tomarmos a formulação em questão, tendo como referencial o imaginário construído na figura de Dom Quixote, nos vemos diante de uma possível filiação em torno de causas impossíveis, relacioandas a amar e continuar amando o trabalho de professor, como se essa fosse uma profissão de fé, como se, caso não houvesse amor à causa, desistir-se-ia dessa prática.

Se recuarmos mais um pouco, afastando-nos do campo da literatura clássica, e acessarmos a história da colonização brasileira, encontraremos um discurso religioso de subordinação por meio de referências à ideia de se manter firme a um ideal por amor a uma causa. No livro de Filipenses, no capítulo 2, versículo 30, encontramos a seguinte fala: "Honrem homens como este, porque ele quase morreu por amor à causa de Cristo, arriscando a vida para suprir a ajuda que vocês não me podiam dar" (Nova..., 2017, p. 1436, grifo nosso). Nessa mesma direção, de devoção e abnegação a uma causa, temos em Coríntios, no capítulo 12 , versículo 15, o seguinte: "desta forma, de boa vontade e por amor de vós, investirei tudo o que possuo e também me desgastarei pessoalmente em vosso favor" (Nova, 2017, p. 1416, grifo nosso).

Em ambos os versículos a ideia de devoção se faz presente, assim como os sentidos de um sujeito pronto para dedicar-se, pronto a sacrificar-se por uma causa que transcende a própria humanidade presente. Os sentidos de superação e determinação, quando se tem devoção à causa, ainda continuam circulando nos meios escolares.

A influência do discurso religioso, sobretudo do cristianismo, na história da implantação da educação escolarizada no Brasil não pode ser negada. Com efeito, a implantação do modelo escolar na colônia portuguesa ficou a cargo dos jesuítas, que fundaram, em 1549, a primeira escola de ler e escrever do Brasil. Do modelo de ensino escolarizado trazido pelos jesuítas no processo de colonização, interessa-nos mais, neste momento, o caráter devocional de que a figura do professor se revestiu ao longo dos tempos.

Ainda é relativamente comum ouvir frases do tipo: "a docência é um sacerdócio"; "ser professor é uma profissão de fé"; "faço isso por amor a Deus", entre outras falas que podem ser remetidas à antiga filiação devocional daqueles que, inicialmente, exerceram a profissão de professor no Brasil. Nesse sentido, para se analisar a construção da posição sujeito-professor, sobretudo no Brasil, é preciso considerar a filiação religiosa de que o termo devoção se revestiu ao longo do processo de colonização e formação da sociedade brasileira.

A posição-sujeito professor no Brasil é atravessada por inúmeros discursos e filiações que constituem a formação dos sujeitos que, por condições diversas, assumem a atividade docente. 0 discurso de coordenadores, professores, gestores educacionais e o próprio currículo dos cursos de formação de professores contribuem para fortalecer as ideias associadas à devoção como característica do exercício do magistério.

Elas estão presentes como um currículo oculto, ou seja, nas formas de ensinar, nos ditos e não-ditos nas aulas em relação à profissão, nos invólucros dos conteúdos, nas formas de constituição da subjetividade do futuro professor, na linguagem de coordenadores de curso e de professores. (Guimarães, 2004, p. 11).

Esses discursos atuam na conformação do sujeito-professor, levando-o a acreditar que o seu esforço pessoal e o seu amor à causa suplantarão a falta de recursos e o descaso com o sistema educacional por parte do Estado. Esses discursos levam-no a crer que ele é parte do problema e, portanto, se ele procurar por mais treinamento ou capacitação, será mais produtivo e eficaz no atendimento ao aluno e no exercício de sua profissão. Assim, vemos o professor como um trabalhador assalariado, imerso no modelo capitalista, a quem também se atribui uma tarefa quase que messiânica de educar as novas gerações.

\section{CONCLUSÃO}

Com a Constituição Federal de 1988, houve previsão da integração escolar como preceito constitucional, preconizando o atendimento aos sujeitos com deficiência na rede regular de ensino. Na década de 90 , iniciaram-se no Brasil as discussões em torno do novo modelo de atendimento escolar denominado inclusão. Com isso, a inclusão escolar passou a centralizar a atenção de educadores.

No entanto, ao atingirmos o objetivo proposto para nossa pesquisa, isto é, ao analisarmos o discurso de professores a respeito dos cursos de formação continuada na área da educação especial na perspectiva inclusiva, percebemos que o processo de inclusão de alunos com deficiência é marcado por diversos conflitos. 0 fato de o professor não saber como trabalhar com esses alunos leva-o a buscar cursos de 
treinamento ou capacitação com a expectativa de que existam práticas bem definidas que possam ser repetidas por ele em sala de aula para garantir a aprendizagem de todos.

Aqueles professores que já se conscientizaram de que não existe um modelo pronto a ser seguido para que a educação especial na perspectiva inclusiva seja bem sucedida acreditam que o amor e a devoção à profissão garantirão a superação dos obstáculos encontrados. Dessa forma, valoriza-se uma concepção da atividade docente segundo a qual o professor, individualmente, é o repsonsável pelo sucesso ou pelo fracasso da aprendizagem dos alunos.

Esses dois caminhos - a busca de treinamento ou capacitação e a excessiva responsabilização do professor - acabam gerando frustração por não garantirem os resultados esperados. Faz-se necessário, portanto, que os professores busquem - e que seja oferecido a eles - mais espaços de reflexão, em que eles possam pensar sobre a educação especial na perspectiva da educação inclusiva de maneira coletiva, buscando compreender melhor os desafios encontrados. Repensando, de maneira constante e coletiva, as práticas docentes e as angústias a elas associadas, os professores ficarão mais bem preparados para buscar soluções adequadas a cada contexto escolar, a cada novo desafio que surgir.

\section{REFERÊNCIAS}

[1] Bourdieu, P. O poder simbólico. 9. ed. Rio de Janeiro: Bertrand Brasil, 2006.

[2] Bordieu, P. Sobre o Estado: cursos no College de France. São Paulo: Companhia das Letras, 2014.

[3] Brasil. Constituição da República Federativa do Brasil de 1988. Brasilia, 1988. Disponível em: http://www.planalto.gov.br/ccivil_03/constituicao/ constituicaocompilado.htm. Acesso em: 10 abr. 2019.

[4] Brasil. Lei no 13.146, de 6 de julho de 2015. Brasília, 2015. Disponível em: http://www.planalto.gov.br/ccivil_03/_Ato2015-2018/2015/Lei/L13146.htm. Acesso em: 10 abr. 2019.

[5] Guimarães, V. S. Formação de professores: saberes, identidade e profissão. Campinas: Papirus, 2004.

[6] Lagazzi, S. O confronto político urbano administrativo na instância jurídica. In: Orlandi, E. P. (org.). Discurso e políticas públicas urbanas: a fabricação do consenso. Campinas: RG, 2010. p. 75-84.

[7] Musis, C. R. D.; Carvalho, S. P. D. Representações sociais de professores acerca do aluno com deficiência: a prática educacional e o ideal do ajuste à normalidade. Educação e Sociedade, Campinas, v. 31, n. 110, p. 110-217, 2010. Disponível em: http;//www.scielo.br/pdf/es/v31n110/11.pdf. Acesso em: 15 abr. 2019. Nova Bíblia Sagrada. São Paulo: Paulus, 2017.

[8] Orlandi, E. P. Discurso em análise: sujeito, sentido, ideologia. 2. ed. Campinas: Pontes, 2012.

[9] Orlandi, E. P. Formação ou capacitação?: duas formas de ligar sociedade e conhecimento. In: Ferreira, E. L.; Orlandi, E. P. (org.) Discursos sobre a inclusão. Niteroi: Intertexto, 2014. p. 141-186.

[10] Pêcheux, M. Semântica e discurso: uma crítica à afirmação do óbvio. Tradução de Eni Puccinelli Orlandi et al. Campinas: Unicamp, 1997. 


\title{
Capítulo 3
}

\section{Atuação do professor coordenador frente a educação especial na perspectiva inclusiva}

\author{
Melina Rosa da Silveira Franco \\ Luci Pastor Manzoli \\ Caio Vinicius dos Santos \\ Evelin Oliveira de Rezende Piza \\ Neusa Aparecida Mendes
}

Resumo: Este trabalho teve por objetivo verificar a atuação dos profissionais de Educação Especial no que se refere à orientação aos professores do ensino regular que lidam com a inclusão de alunos com deficiência, em uma escola estadual do interior paulista. Primeiramente levantamos alguns elementos legais em relação à Educação Especial como a Constituição Federal de 1988 que garante educação a todos como dever do Estado. Além deste, foram consultados também documentos referentes à Conferência de Jomtien (1990) e a Declaração de Salamanca (1994) que se constituem como um marco histórico para a compreensão das necessidades e os princípios da educação inclusiva na perspectiva da Educação Especial. Sob essa ótica, mencionamos ainda a LDB de 1996 e outras fontes governamentais referentes à Educação Especial no Brasil como o Plano Nacional da Educação e resoluções da Secretaria da Educação do Estado de São Paulo. Dessa forma, os citados documentos foram fundamentais para que subsidiássemos nossa análise sobre o plano de ação semestral do Professor Coordenador de uma escola de periferia do interior paulista. Foi verificado que o plano teve como escopo orientar todos os professores da escola a respeito do atendimento de qualidade aos alunos com deficiência. Visto a organização do plano de ação, identificamos, além da sua aplicabilidade, a participação dos profissionais da Educação Especial frente ao grupo de professores do ensino regular. Por fim, concluímos que um plano organizativo, conforme o encontrado, demonstra possibilitar tomadas de decisões que contribuem para a aprendizagem desses alunos, por promover alternativas para a solução de situações-problema, bem como na intervenção da aprendizagem. Esse trabalho mostrou que nessa escola está havendo um esforço coletivo visando por um lado a equiparação de oportunidades e desenvolvimento num preparo para o acolhimento, participação e aprendizagem desses alunos, e por outro, o respeito aos diferentes ritmos de aprender, ao rompimento de práticas pedagógicas cristalizadas, fazendo ocorrer uma nova forma ao modo de ensinar. 


\section{INTRODUÇ̃̃OO}

A Educação Especial, a partir do processo de democratização da educação, demonstra a contradição de inclusão/exclusão, pois os sistemas de ensino universalizam o acesso, mas continuam excluindo indivíduos e grupos considerados fora dos padrões homogêneos da escola. Historicamente, a Educação Especial baseouse no conceito de normalidade/anormalidade, criando instituições especializadas, escolas especiais e classes especiais, pois o atendimento educacional especializado era substituto ao ensino comum. (Portaria n. 948/2007). A Constituição Federal de 1988 define no Art. 208 que a educação é dever do Estado e será efetivada mediante a garantia de "atendimento educacional especializado aos portadores de deficiência, preferencialmente na rede regular de ensino". (Brasil, 1988). A Declaração Mundial de Educação para Todos - Conferência de Jomtien - (1990), que aconteceu na Tailândia, e teve como proposta o plano de ação para satisfazer as necessidades básicas de aprendizagem, em seu artigo 3 que trata sobre a universalização do acesso à educação e promoção da equidade, pontua que é necessário "universalizar e melhorar a qualidade, e tomar medidas efetivas para reduzir as desigualdades". Continua apontando sobre a importância de promover a igualdade de acesso independentemente do tipo da deficiência apresentada no contexto educativo. (Brasil, 1990). No ano de 1994 a Declaração de Salamanca propõe princípios dispondo os alunos que apresentam "necessidades educacionais especiais devem ter acesso à escola regular, e que dever acomodá-los dentro de uma Pedagogia centrada na criança, capaz de satisfazer a tais necessidades" (Brasil, 1994). De acordo com essa Declaração, os princípios fundamentais da escola inclusiva estão voltados para a aprendizagem conjunta de todos os alunos, independentemente das dificuldades e das diferenças que apresentem, as escolas devem adaptar-se aos vários estilos e ritmos de aprendizagem, prever recursos de serviços de apoio, adequação curricular e estabelecer estratégias pedagógicas para atender "o conjunto de necessidades especiais dentro da escola". (Declaração DE Salamanca, 1994). A LDB 9394/96, em seu capítulo 5 no Art.58 trata da educação especial como uma modalidade de educação escolar que deve ser oferecida preferencialmente na rede regular de ensino para educandos portadores de necessidades especiais. No inciso 1 e 2 respectivamente afirma que o serviço de educação especializada na escola regular, deve atender as particularidades da clientela de educação especial, sendo realizado em classes, escolas ou serviços especializados, para atender as condições específicas dos alunos se não for possível a sua integração nas classes comuns do ensino regular. No artigo 59 fica assegurado sobre a importância de professores "capacitados em nível médio ou superior, para atendimento especializado, bem como professores do ensino regular capacitados para a integração desses educandos nas classes comuns". (Brasil,1996). As Diretrizes Nacionais para a Educação Especial na Educação Básica (2001), preconiza a construção de uma sociedade inclusiva, para o desenvolvimento e manutenção de um estado democrático, sendo entendido por inclusão a garantia de acesso contínuo, relações de acolhimento a diversidade humana e aceitação das diferenças individuais, com qualidade, em todas as dimensões da vida. (Brasil 2001). A Lei n. 10.172/01, que regulamenta o Plano Nacional da Educação, pontua, sobre a formação docente, a acessibilidade física e ao atendimento educacional especializado preferencialmente na rede regular de ensino. (Brasil,2001). De acordo com artigo 70 da Resolução SE 11/2008, deve-se considerar as "especificidades regionais e locais", de acordo com as necessidades da unidade escolar para a solicitação "do Serviço de Apoio Pedagógico Especializado - SAPE, desde que acompanhados dos termos de anuência da Diretoria de Ensino e da respectiva Coordenadoria de Ensino". (SEE/SP,2008). Essa mesma Resolução trata sobre a implementação do SAPE, sob a forma de sala de recursos que tem por meta melhorar a qualidade da oferta da educação especial na rede estadual de ensino, bem como, a inclusão do aluno com deficiência em classes comuns do ensino regular. 0 atendimento pelo professor especializado nessas salas deve ocorrer em horários programados e no contra turno da classe da sala comum, na própria escola ou em outra unidade, na forma itinerante. (SEE/SP, 2008). A Resolução 61/2014 trata da Educação Especial nas unidades escolas da rede estadual de ensino e nesta pontua sobre o direito do aluno a uma educação de qualidade, a necessidade de se garantir o atendimento aos diferentes ritmos de aprendizagem dos alunos e a importância de se assegurar aos alunos público-alvo da Educação especial o Atendimento Pedagógico Especializado - APE. (SEE/SP, 2014). A Deliberação CEE n. 149/2016, estabelece normas para a educação especial no sistema estadual de ensino e em seu artigo 11, estabelece que após avaliação multiprofissional e pedagógica, deverão estar previstas no Regimento Escolar e na Proposta Pedagógica das escolas, respeitadas as normas do sistema de ensino e da LDB 9394/96, os casos de encaminhamento para instituição especializada. (CEE/SEE 2016). A Resolução SE 68/2017 chama a atenção "sobre o direito do aluno à educação de qualidade, igualitária, inclusiva e centrada no respeito à diversidade humana" e sobre a importância dos profissionais da escola se envolverem no ensino de qualidade a todos com vistas a diminuir ou abolir os obstáculos encontrados no processo educativo. 
Esta resolução, também menciona sobre o Professor Interlocutor de Libras "para atuar em sala de aula e nos diferentes espaços de aprendizagem em que se desenvolvam atividades escolares, com os alunos que apresentem surdez/deficiência auditiva e que fazem uso da língua". (SEE/SP,2017). Diante desse novo padrão escolar que leva em consideração a diversidade e um ensino de qualidade a todos os alunos, a figura do professor coordenador, de acordo com a Resolução 75 de 2014, exerce importância "no fortalecimento das ações de orientação e aperfeiçoamento do fazer pedagógico em sala de aula" bem como na "condução de alternativas de solução de situações - problema e nas decisões de intervenção imediata na aprendizagem, com atendimento das necessidades dos alunos". (SEE/SP, 2014).

\section{OBJETIVO}

Verificar como ocorre a atuação dos profissionais de Educação Especial no que se refere à orientação aos professores do ensino regular que estão lidando com a inclusão de alunos com deficiência em uma escola estadual do interior paulista.

\section{DESENVOLVIMENTO}

A escola está localizada em uma região da periferia em uma cidade do interior paulista, e atende o ensino fundamental anos finais, (60 ao 90 ano) com 264 alunos, no ano de 2018. E no ensino médio, 179 alunos, abrangendo um total de 443 alunos regularmente matriculados. São em sua maioria provenientes de classe social com renda de até dois salários mínimos, sendo muitas delas, dependentes de Bolsa Família. Desse total, a escola atende dois alunos com deficiência sendo elas: surdez/deficiência auditiva e deficiência física e intelectual (múltipla). A escola dispõe dois profissionais especializados, sendo um professor interlocutor de língua brasileira de sinais - LIBRAS para atuar junto ao aluno com surdez/deficiência auditiva no período regular de sala de aula. E um professor especializado do SAPE ensino itinerante, para atender o aluno com deficiência múltipla no período oposto ao de aula. Esse aluno conta também com o apoio de uma cuidadora para atender as suas necessidades de locomoção apenas no período normal de aula do ensino regular. Frente a importância da inclusão escolar, a professora coordenadora organizou um plano de ação para orientar todos os professores da escola, a respeito do atendimento de qualidade a esses alunos. Dessa forma, planejou as reuniões de Aula de Trabalho Pedagógico Coletivo - ATPC que são reuniões semanais obrigatórias com os professores com duração de 2 horas que ocorrem nessa escola, 3 vezes por semana, sendo que em cada reunião, há professores de diferentes áreas. A professora coordenadora elaborou um plano de ação para atender os professores que foram divididos em três grupos de acordo com os horários disponíveis de cada, um propondo o desenvolvimento das seguintes atividades: - Estudo sobre: a) Resolução 11/2008 que além de dispor sobre a educação escolar de alunos com necessidades especiais, também pontua sobre o atendimento do SAPEs; b) Resolução 61/2014, que trata sobre educação especial nas unidades escolares; c) Resolução 68/17 que trata do público alvo da Educação Especial na rede estadual de ensino e a atuação do Professor Interlocutor de Libras. - Quanto à Professora Interlocutora de Libras: a) Orientação aos professores com a Professora Interlocutora de Libras que explanou sobre a importância do seu trabalho com o aluno com surdez/deficiência auditiva; b) Orientação aos professores de como direcionar o trabalho em sala de aula para melhor atendimento à esse aluno e contribuir em relação à aprendizagem do aluno; c) Ensino de alguns sinais em Libras para os professores; d) Ensino de alguns sinais em Libras para os alunos ouvintes da sala; e) Oferecimento de alguns subsídios para que os professores elaborassem atividades pedagógicas adaptadas às necessidades do aluno com surdez. E esses planos eram reelaborados à medida em que fossem necessários. - Quanto à Professora especializada que faz atendimento junto ao SAPE, com o aluno que possui deficiência física e intelectual, o direcionamento prosseguiu com a apresentação de algumas estratégias de ensino, para que os conteúdos trabalhados em sala de aula fossem planejados com adaptações curriculares. - Apresentou o portfólio de atendimento conforme consta no Anexo I da resolução 11/2008, que é um roteiro descritivo anual de observação do aluno, pontuando sobre os itens A, $\mathrm{B}, \mathrm{C}$ e D desta resolução. $\mathrm{O}$ item A diz respeito à intervenção e interação afetiva, social e familiar, ou seja, o histórico do aluno, desde suas características nos diferentes grupos de convívio, como também os antecedentes de natureza clínica e terapêutica. Sequencialmente o item B, que trata da avaliação do professor especialista, com a observação descritiva nas diversas situações escolares. 
O item C que relata as observações do Professor especialista e as condutas a serem seguidas e por fim o item D sobre os registros do aluno ao longo do ano. - Explicou o Anexo II da mesma resolução sobre o Portfólio de atendimento, que é a ficha de acompanhamento diário do aluno que é elencado em três itens: primeiro contém informações gerais do aluno, o segundo, as ações que os professores desenvolvem com os alunos e o terceiro descreve os materiais preparados para o aluno e/ou professor da sala comum. Explanou o Anexo III - Portfólio de atendimento, sendo a ficha de acompanhamento bimestral do aluno, nesta contempla 4 itens, sendo as informações gerais, os objetivos dos atendimentos no bimestre, se foi necessária alguma intervenção especial e por fim a caracterização do atendimento. Durante o semestre da aplicação do programa de orientação proposto pela professora coordenadora, tanto com a Professora Interlocutora, quanto a Professora do SAPE, os professores do ensino regular envolvidos no ATPC sanavam suas dúvidas, faziam comentários sobre o cotidiano de suas salas de aula e as professoras especialistas, ilustravam com exemplos de ações pontuais que poderiam ser desenvolvidas através do trabalho colaborativo.

\section{CONCLUSÕES}

Este trabalho mostrou a atuação semestral de duas professoras de educação especial, mediante o plano de ação proposto pela Professora Coordenadora de uma escola de periferia, denotando a importância da articulação entre os professores do ensino regular e especial. Um plano organizativo conforme o exposto, demonstra possibilitar tomadas de decisões que contribuem para a aprendizagem desses alunos, por promover alternativas para a solução de situações-problema, bem como na intervenção da aprendizagem. Neste sentido, acredita-se que nessa escola está havendo um esforço coletivo visando por um lado, a equiparação de oportunidades e desenvolvimento num preparo para o acolhimento e aceitação desses alunos, e por outro, o respeito aos diferentes ritmos de aprender, ao rompimento de práticas pedagógicas cristalizadas, fazendo ocorrer uma nova forma ao modo de ensinar. Vê-se, portanto, a importância de um trabalho conjunto procurando orientar e promover estruturas de apoio escolar aos docentes, oferecendo subsídios para as atividades em sala de aula e originando situações de direcionamento sobre a prática do professor. Diante o contexto inclusivo, torna-se necessário um novo olhar para a formação do educador, principalmente, por exigir dele mudanças em seu fazer pedagógico e de ações e atitudes que respeite e compreenda as diferenças e limites de seu alunado, de modo que promova uma educação com qualidade e equidade a todos, independentemente dos atributos que dispõem.

\section{REFERÊNCIAS}

[1] Brasil, Diretrizes Nacionais para a Educação Especial na Educ ação Básica da Nacional. Brasília: MEC, 2001.

[2] Brasil, LDB. Lei 9394/96 - Lei de Diretrizes e Bases da Educação Nacional. Disponível em < www.planalto.gov.br >. Acesso em: mar. 2018.

[3] Brasil. Lei n. 10.172/01 - Plano Nacional de Educação. Disponível em: . Acesso em: 30 mar. 2018.

[4] Brasil. Secretaria de Educação Especial. Política Nacional de Educação Especial na Perspectiva da Educação Inclusiva. Brasília, DF, jan. 2008a. [Documento elaborado pelo Grupo de Trabalho nomeado pela portaria n. 555/2007, prorrogada pela portaria n. 948/2007, entregue ao ministro da Educação em 7 de janeiro de 2008]. Disponível em: < http://portal.mec.gov.br/arquivos/pdf/politicaeducespecial.pdf>. Acesso em: mar. 2018.

[5] Brasil. Constituição (1988). Constituição da República Federativa do Brasil. Brasília, DF: Senado Federal: Centro Gráfico, 1988. 292 p.

[6] Declaração de Salamanca: Sobre Princípios, Políticas e Práticas na Área das Necessidades Educativas Especiais, 1994, Salamanca-Espanha.

[7] Organizações das Nações Unidas para a Educação, Ciência e Cultura - Unesco. Declaração Mundial sobre Educação Para Todos (Conferência de Jomtien). Tailândia: Unesco, 1990.

[8] São Paulo. CEE. Portaria n.149. 2016.

[9] São Paulo. Resolução n.75. 2014.

[10] São Paulo. SE. Resolução n. 11. 2008

[11] São Paulo. SE. Resolução n. 61. 2014.

[12] São Paulo. SE. Resolução n. 68.2017. 


\section{Capítulo 4}

\section{Inclusão escolar na educação básica: A atuação da Psicologia}

\section{Anna Lúcia Sampaio Marchesini \\ Fernanda Vaz Torres}

Resumo: A educação inclusiva, desde a Declaração de Salamanca (1994), começou a ser discutida mundialmente. As escolas precisaram adequar-se estruturalmente e curricularmente para receber as pessoas com deficiência. No Brasil, a partir da Lei Brasileira de Inclusão, Lei № 13.146 (BRASIL, 2015), tornou-se obrigatória as escolas regulares receberem estes alunos e os incluírem da melhor forma possível. Este artigo objetivou analisar o trabalho do psicólogo escolar na inclusão escolar da educação básica. Foi realizada revisão bibliográfica e aplicado um questionário online, através do Google formulários, para professores da educação básica, dos níveis públicos e privados de ensino. Foram obtidas 45 respostas que permitiram concluir que o cenário da inclusão escolar está longe de ser o ideal previsto pela teoria e pelas leis. A maioria dos respondentes afirmaram que necessitam de auxilio para realizar a educação inclusiva dentro da sala de aula, assim como de materiais e maior capacitação.

Palavras-Chave: Inclusão Escolar; Psicologia Escolar; Educação Especial; Psicologia e Educação; Lei Brasileira de Inclusão. 


\section{INTRODUÇÃO}

Segundo Machado, Almeida e Saraiva (2009) a inclusão remete a um conflito histórico e pertencente a certo funcionamento social, determinado pela exclusão social. Falar de inclusão, portanto, é observar a constituição excludente e desigual da sociedade. 0 termo inclusão é associado ao campo dos direitos humanos e aos conceitos de igualdade, fraternidade e democracia. "A inclusão escolar teve as suas origens no centro das pessoas em situação de deficiência e insere-se nos grandes movimentos contra a exclusão social (...) tendo como princípio a defesa da justiça social" (AINSCOW E FERREIRA, 2003 apud TEODORO E SANCHES, 2006, p.69).

Por meio da Declaração de Salamanca (1994), 92 países e 25 organizações internacionais comprometeram-se com os princípios da escola inclusiva:

O princípio fundamental das escolas inclusivas consiste em todos os alunos aprenderem juntos, sempre que possível, independentemente das dificuldades e das diferenças que apresentem. Estas escolas devem reconhecer e satisfazer as necessidades diversas dos seus alunos, adaptando-se aos vários estilos e ritmos de aprendizagem, de modo a garantir um bom nível de educação para todos, através de currículos adequados, de uma boa organização escolar, de estratégias pedagógicas, de utilização de recursos e de uma cooperação com as respectivas comunidades. É preciso, portanto, um conjunto de apoios e de serviços para satisfazer o conjunto de necessidades especiais dentro da escola. (Declaração de Salamanca, 1994: 11-12).

Depreendemos com a Declaração de Salamanca que a educação é para todos, independentemente das dificuldades e diferenças existentes. Para que a educação se constitua como inclusiva é preciso que a sociedade se organize por meio de um conjunto de serviços especiais. Teodoro e Sanches (2006) afirmam que só pode existir em uma escola inclusiva, uma educação inclusiva, onde a heterogeneidade dos alunos não é um problema, mas um convite a criatividade e ao profissionalismo dos educadores, ocasionando mudanças de mentalidades, de políticas e de práticas.

Rabelo e Amaral (2003, p.213) citam que muito já foi discutido para a implementação da escola inclusiva, "porém ainda não foi definido como será e como poderá ser feita a qualificação dos professores que estarão atuando diretamente com esses alunos."

A psicologia como ciência que tem um importante compromisso social necessita aproximar-se do campo dos direitos humanos e das políticas referentes a inclusão (BRASIL, 2008; 2015) que buscam assegurar e promover, em condições de igualdade, o exercício dos direitos e das liberdades fundamentais da pessoa com deficiência, visando à sua inclusão social e cidadania. Neste sentido, a construção da inclusão na educação necessita contar com o trabalho dos profissionais de psicologia nos diversos espaços de subjetivação que a pessoa se constitui.

É trabalho do psicólogo escolar, portanto, auxiliar o fazer pedagógico dos professores na escola, atuando como agente de mudanças dentro da instituição escolar, bem como posicionando-se como elemento centralizador de reflexões e conscientizador dos papéis representados pelos grupos que compõem a instituição (MARTINS, 2003). Nesse sentido, este artigo tem como objetivo analisar a atuação do psicólogo escolar na inclusão escolar da educação básica, e como objetivos específicos: apontar as principais estratégias utilizadas pelos psicólogos na inclusão escolar na educação básica; discutir a criação de estratégias que assegurem a inclusão por psicólogos escolares junto aos professores; descrever as principais dificuldades encontradas pelos professores no processo de inclusão escolar.

0 estudo tem como questão norteadora: Como os psicólogos escolares podem auxiliar os professores a criar estratégias para alunos de inclusão? Compreende um questionamento construído nas atividades de estágio extra-curricular em escola de educação infantil e séries iniciais do ensino fundamental por três anos. Em conversas informais percebemos as dificuldades que os profissionais de psicologia e pedagogia apresentam para lidar com a inclusão de alunos com deficiência. As pesquisas (BEYER, 2010) apontam que a inclusão escolar é um assunto extremamente discutido atualmente por todos os setores sociais. Com o advento da Lei Brasileira de Inclusão, Lei $N^{\circ} 13.146$ (BRASIL, 2015), as escolas precisaram se adequar para atender as novas demandas exigidas pela legislação.

O Artigo 27 da Lei $N^{\circ} 13.146$ (BRASIL, 2015) estabelece que a educação é um direito da pessoa com deficiência, que deve ser assegurado pelo sistema educacional inclusivo em todos os níveis e aprendizado ao longo da vida. A escola tem recebido um grande número de alunos com diferentes deficiências e transtornos de aprendizagem que precisam de acessibilidade pedagógica, comunicacional e atitudinal 
para permanecerem matriculados e, neste contexto, os profissionais de psicologia tem sido convocados a colaborar com o trabalho pedagógico. 0 psicólogo escolar é um dos principais agentes da inclusão dentro de uma escola. Ele atua como ponte entre o professor e o aluno, criando junto com estes, estratégias para o adequado cumprimento do processo de ensino e aprendizagem, assegurando o acesso e permanência dos alunos. Deste modo, justifica-se este projeto que resultará numa pesquisa que fornecerá dados relevantes para a construção de um corpo de conhecimentos mais consistentes sobre as contribuições da atuação dos profissionais de psicologia nas escolas de educação infantil.

\section{REFERENCIAL TEÓRICO}

\section{Inclusão Escolar - Histórico}

Constitui a base teórica deste estudo um breve histórico sobre o paradigma da inclusão escolar, destacando a educação especial, os avanços na legislação e nas ações que contemplaram diversos tipos de deficiências e as contribuições da Psicologia Escolar as práticas de inclusão.

Com o surgimento da Lei Brasileira de Inclusão, Lei № 13.146 (BRASIL, 2015) todas as escolas precisaram se adaptar curricular e estruturalmente para receber as crianças com deficiências. A escola, portanto, não pôde mais ignorar o que estava acontecendo ao redor, nem marginalizando e anulando as diferenças nos processos pelos quais forma e instrui os alunos (MANTOAN, 2003).

Para se adequar a esta nova realidade foi preciso uma transformação em todos os âmbitos que circundam uma escola. De acordo com Nascimento, Scapim e Silveira (2003), apenas adaptações para os espaços que recebem alunos com deficiências não são suficientes para que a educação ocorra no nível desejado, pelo fato de existirem alunos com diversas demandas, singularidades e subjetividades.

Para chegar a criação da Lei, entretanto, foi necessário um longo processo, iniciado através da Educação Especial e então, culminado na Educação Inclusiva.

A educação especial, no Brasil, foi marcada por dois momentos. De 1854 a 1956 houve iniciativas no âmbito particular e oficiais, porém isoladas. De 1957 a 1993 as iniciativas oficiais foram de âmbito nacional (MAZZOTTA,2003).

Em 12 de setembro de 1854, Dom Pedro II, através do Decreto Imperial $\mathrm{n}^{\circ} 1.428$, fundou o Imperial Instituto dos Meninos Cegos, no Rio de Janeiro, que em 1891 passou a denominar-se Instituto Benjamin Constant (IBC). Três anos após a criação deste, fundou também no Rio de Janeiro o Imperial Instituto dos Surdos-Mudos. Em 1957, cem anos após a sua criação, passou-se a chamar Instituto Nacional de Educação de Surdos - INES. Nestes institutos existiam oficinas como topografia, encadernação, tricô, douração e etc. Em 1883, no $1^{\circ}$ Congresso de Instrução Pública, convocado pelo imperador, figurou-se temas como a sugestão de currículo e formação de professores para cegos e surdos (MAZZOTTA,2003).

Em 1874, o Hospital Estadual de Salvador (atual Juliano Moreira) iniciou a assistência aos indivíduos portadores de deficiências intelectuais. No começo do século XX, é notório o interesse pela educação especial através de trabalhos científicos publicados e cota-se até este período cerca de quarenta estabelecimentos públicos que promoviam atendimento escolar especial para deficientes mentais (MAZZOTTA, 2003). Existiam também outros espaços, públicos e particulares, que prestavam este suporte a outras deficiências. Destaca-se, por exemplo, o Instituto de Cegos da Bahia, criado em 1936, em salvador.

Em 1957, o governo federal criou a primeira medida para a educação de deficientes a nível nacional, a Campanha para a Educação do Surdo Brasileiro - C.E.S.B - através do Decreto Federal n 42.728 . Esta tinha como objetivo promover educação e assistência em todo território nacional. Dentre todas as campanhas criadas, Mazzotta (2003) ressalta a relevância da Campanha Nacional de Educação e Reabilitação de Deficientes Mentais - CADEME, a importância dada a esta se encontra no fato dela ser presidida por 3 indivíduos escolhidos pelo ministro da educação e cultura, além de existir um fundo especial, de natureza bancária, para pôr em prática as demandas da campanha.

Em 1972 surge o Grupo-Tarefa de Educação Especial, cujo resultados culminaram para a criação do Centro Nacional de Educação Especial - CENESP. Com isso, as campanhas que estavam sendo executadas na época, foram extintas e todo o fundo delas, passado para o CENESP. Em 1986, o Centro foi então transformado na Secretária de Educação Especial - SESPE. Em 1990 o Ministério da Educação foi reestruturado e assim, a SESPE foi finalizada. A Educação Especial ficou por conta da Secretaria Nacional de Educação Básica SENEB. Em 1990 essa medida foi oficializada, através do Decreto $n^{\circ} 99.678$, que incluiu como órgão da SENEB o Departamento de Educação Supletiva e Especial - DESE. Outro aspecto importante a se destacar 
deste ano consiste na participação do Brasil na Conferência Mundial sobre Educação para Todos, em Jomtien, na Tailândia. Após assinar a Declaração Mundial sobre Educação para Todos, o país se comprometeu com o direito universal da educação.

Após o governo Collor de Melo, em 1992, novamente houve uma reorganização dos Ministérios e a Secretária de Educação Especial - SEESPE reapareceu como órgão específico do Ministério da Educação e do Desporto. Em 1993, conclui-se o documento denominado Plano Decenal de Educação para Todos, elaborado a partir da Conferência Mundial sobre Educação para Todos, em 1990. Este Plano possuía como objetivo proporcionar a todos os brasileiros, até a sua finalização "conteúdos mínimos de aprendizagem que atendam necessidades elementares da vida" (BRASIL, 1993, p. 13)

Em 1994, houve o mais importante evento já acontecido sobre Educação Especial. A Conferência Mundial sobre Necessidades Educativas Especiais ocorreu na Espanha e corroborou com a elaboração da Declaração de Salamanca. Este contribuiu com a mudança nos modelos escolares ao propor a educação de pessoas com deficiência como parte integrante do sistema educacional, ou seja, também nas escolas regulares. Esta convenção demandou a todos os governos e a comunidade internacional a endossar as propostas da educação inclusiva e fazer disso um propósito para o futuro. Ela consistiu, veementemente em um novo pensar sobre educação especial.

A Lei das Diretrizes e Bases da Educação Nacional - LDB - é promulgada em 1996 (BRASIL, 1996), propondo para as escolas a inclusão e a adaptação para se adequar e acolher a todos os indivíduos. A Educação Inclusiva, portanto, passa a ser discutida e apoiada pelo país, principalmente, pelos profissionais que trabalhavam em prol da Educação Especial. Ao invés de apenas integrar, a prática educativa passou a consistir no incluir.

No ano de 2006, houve a Convenção Internacional para a Proteção e a Promoção dos Direitos e Dignidade das Pessoas com Deficiência. Neste evento, decidiu-se que o termo correto para nomear indivíduos especiais seria pessoas com deficiência. Atribui-se a isso a importância de não mascarar a deficiência, bem como valorizar as diferenças (GUEDES, 2012).

Em 2008 a Política Nacional da Educação Especial na perspectiva da educação inclusiva (BRASIL, 2008) instituiu o atendimento educacional especializado e a necessidade de formação de professores para o trabalho e construção da escola inclusiva. Com a Política são instituídas as salas multifuncionais (salas de recursos) para oferecer atendimento educacional as crianças com deficiência matriculadas na escola, porém no turno oposto.

De acordo com Mantoan (2003) há uma cisão entre o que os professores aprendem e o que eles colocam em prática na sala de aula. Ensinar, na perspectiva inclusiva, significa ressignificar o papel do professor, da escola, da educação e de práticas pedagógicas que são usuais no contexto excludente do nosso ensino, em todos os níveis (MANTOAN, 2003, p. 43).

É importante destacar os avanços na inclusão escolar como a oferta das salas multifuncionais, a contratação de interpretes da língua de sinais e o preparo dos professores. As mudanças ocorridas na terminologia referentes a designação de pessoas com deficiência, com a alteração na LDB 9394/96, que ocorreu em 2013, modificando a classificação, favoreceu os processos de inclusão e empoderamento das pessoas com deficiência.

\section{0 entrelace da inclusão e a psicologia escolar}

É importante discutir a relação entre a psicologia e a educação a partir de sua interdependência (ANTUNES, 2000). As práticas educativas no Brasil são influenciadas pela psicologia desde o período colonial, assim como a psicologia é influenciada pelas demandas educacionais que corroboraram pelo estabelecimento desta como ciência e profissão.

Lima (2011) relata que no período colonial, muitas obras sobre educação foram escritas, principalmente com a psicologia entrelaçada. Pode-se citar a aprendizagem; natureza dos determinantes pedagógicos da criança; influência dos pais sobre o desenvolvimento dos filhos; desenvolvimento sensorial, motor, intelectual, emocional e motivacional; o papel do jogo no desenvolvimento; controle e manipulação do comportamento (...) (ANTUNES, 2000 apud LIMA,2011).

No Século XIX houve também a criação das primeiras faculdades de medicina do Brasil, local onde a produção de ideias psicológicas atreladas a escola a educação se fez presentes. Para Antunes (2000), no 
final deste século pode-se considerar a efetivação do cenário que anos depois, veio a ser considerado como Psicologia da Educação.

No início do Século XX surgem as escolas normais e abre-se um grande campo para o desenvolvimento da psicologia. Nestes locais, existiam laboratórios de psicologia, responsáveis por capacitar os professores para uma melhor prática escolar (ANTUNES, 2003). É importante destacar nomes como Helena Antipoff, Ulisses Pernambuco e Noemy Rudolfer, pioneiros na Psicologia como instrumento de transformação nas escolas e principalmente, na educação. Estes já promoviam ações que hoje são defendidas pela Psicologia Escolar e Educacional, como a necessidade de se construir uma parceria entre a escola e a família, a inclusão de professores e pais para pensarem sobre o não aprender na escola, busca pela melhoria da qualidade de ensino (LIMA, 2011).

Em 1930, o país estava tomado pelo forte crescimento da industrialização. Com isso, surge um movimento para que todos os indivíduos sejam alfabetizados e passem pela escola, com o objetivo de possuir mais mão de obra com, pelo menos, mínima formação para trabalhar nestes novos postos de trabalho. Este quadro, portanto, favoreceu a aliança entre a Psicologia e a Educação, na medida em que esta estava comprometida no desenvolvimento de trabalhos que analisavam o processo pedagógico e principalmente, a aprendizagem infantil (ANTUNES,2000). Neste período, surgem também as Escolas Novas, a partir da necessidade de um novo olhar sobre o sujeito em construção. A psicologia, então, ganha força neste movimento, a partir da necessidade da Escola Nova em conhecer como ocorre o desenvolvimento infantil, pois fornece para este todo embasamento científico preciso. (LIMA, 2011).

Neste ano, a Psicologia entrou formalmente nas Universidades, como disciplina nos cursos de Pedagogia e Filosofia. Até a profissionalização da Psicologia no Brasil, em 1962, esta seguiu atrelada a educação, sustentando suas práticas e consolidando o seu caminho. Em 1970, entretanto, surge um novo discurso que critica o que estava sendo produzido no entrelace Psicologia e Educação. Ele alegava, principalmente, a visão reducionista de atribuir as dificuldades encontradas no processo educacional somente a fatores emocionais e psicológicos do educando (ANTUNES, 2007).

0 uso excessivo de testes as consequências desta prática para a vida dos alunos representavam as principais críticas ao campo da Psicologia Escolar e Educacional. Os resultados das avaliações psicológicas eram interpretados fora do contexto que aquele estudante estava submetido, como as condições sociais, externas a escola. Por conta deste fato, muitas crianças diagnosticadas erroneamente eram encaminhadas para classes especiais e de ensino inferior, o que culminava em um pequeno desenvolvimento. Antunes (2007) ressalta que apesar da Psicologia ter pautado o seu caminho no auxílio da construção de métodos adequados de ensino para os alunos, o que realmente ocorreu foi o uso de teorias e técnicas psicológicas que ocasionaram a exclusão destes do processo escolar.

Loureiro (1997) afirma que a Psicologia Escolar foi criticada pelo estigma psicologista, que é a tendência a reduzir ao nível individual e grupal realidades que são sociais. 0 indivíduo, portanto, era visto isoladamente, fora do contexto no qual estava inserido. A partir dessa nova perspectiva, de incluir o sujeito no seu meio e então elaborar uma nova forma de pensar a psicologia e a educação, surge o que se conhece atualmente como Psicologia Escolar e Educacional.

Pensar nessa nova psicologia é compreender o sujeito como um ser biopsicossocial, produto e produtor das relações sociais (LIMA, 2011). O psicólogo que atua nessa perspectiva busca dar importância ao trabalho coletivo dentro das escolas, enfatizando a autonomia, consciência crítica e liberdade dos indivíduos. Este trabalha juntamente como diretores, professores, orientadores e pais, buscando as condições necessárias para o desenvolvimento e a aprendizagem do sujeito. 0 psicólogo escolar atua mediando os processos de ensino e aprendizagem, criando espaços de escuta e proporcionando acolhimento as demandas provenientes da sala de aula e dos alunos, individualmente.

Mantoan (2003) referencia a escola como um local que se encheu de formalidades, burocracia. Ela explana a inclusão como uma prática para que a escola possa fluir novamente, possuindo uma ação verdadeiramente formadora. As instituições de ensino, cada vez mais, precisam estar preparadas para receber qualquer tipo de aluno. Não há mais separação entre as escolas especiais e as escolas regulares. "O monopólio histórico da educação especial parece estar chegando ao fim" (BEYER, 2010, p. 11)

Estima-se que a escola do futuro seja para todos. A história destes locais, contudo, evidencia uma trajetória muito distante deste sonho. Escola e educação formal sempre foram um privilégio de poucos, privilégio dos poderosos (BEYER, 2010). As escolas nunca receberam todo tipo de aluno, sempre houve uma seleção. Todas elas foram escolas especiais, ou seja, para crianças selecionadas. Somente com o 
surgimento das instituições específicas para crianças com deficiência - as "escolas especiais" - este público, finalmente, possuiu a chance de frequentar uma escola.

Em 2008 a Política Nacional da Educação Especial na perspectiva da educação inclusiva instituiu o atendimento educacional especializado e a necessidade de formação de professores para o trabalho e construção da escola inclusiva. De acordo com Mantoan (2003) há uma cisão entre o que os professores aprendem e o que eles colocam em prática na sala de aula. Ensinar, na perspectiva inclusiva, significa ressignificar o papel do professor, da escola, da educação e de práticas pedagógicas que são usuais no contexto excludente do nosso ensino, em todos os níveis (MANTOAN, 2003, p. 43).

Dazzani (2010) afirma que ao avaliar a prática do psicólogo escolar, nos últimos anos, não se consegue conceber uma participação estritamente positiva. A psicologia colaborou para a manutenção da lógica da exclusão, no momento em que transferiu para a escola aspectos trabalhados em cenários clínicos. A au tora sugere que a preocupação atual que cerceia a temática da inclusão e a atuação da psicologia gira em torno de fatores como: o que faz este profissional se infiltrar em questões que fogem do patamar psicológico e adentram questões sociológicas, culturais e principalmente, pedagógicas; estabelecimento de um novo perfil do psicólogo escolar e educacional, que esteja envolvido em noções de cidadania, saúde e qualidade de vida; reflexões sobre o papel da psicologia na formação dos professores; dentre outras (DAZZANI,2003).

\section{MÉTODOS}

Este trabalho se configura como uma pesquisa qualitativa descritiva, que foi realizada através de revisão bibliográfica e aplicação de questionário para professores e psicólogos escolares da educação básica e das redes pública e particular de ensino, através do Google formulários.

0 questionário foi disponibilizado em redes sociais da internet e ficou disponível por duas semanas. Estruturou-se por 13 perguntas, com duração média de 2 (dois) a 5 (cinco) minutos. Foi informado aos participantes o objetivo do questionário, assim como explicado que ele não possuiria nenhum custo financeiro para responde-lo, nem receberia nada por isso. Foi esclarecido aos participantes que os dados obtidos com o questionário seriam divulgados através de um artigo, porém que a identidade deles permaneceria em sigilo durante todo o processo.

O questionário consistiu em 7 perguntas de múltipla escolha e 6 perguntas de respostas curtas, permitindo assim a construção de gráficos para melhor ilustração das respostas.

\section{RESULTADOS E DISCUSSÃO}

Foram obtidas 45 participações ao questionário, mas não necessariamente 45 respostas para cada pergunta.

O questionário iniciou indagando o perfil dos participantes, se estes são professores da rede particular ou pública, bem como o nível de ensino ao qual eles estão inseridos, obtendo como resultado que 32 trabalham na rede pública e 10 na rede privada. Em relação ao nível de ensino, observa-se no gráfico a seguir:

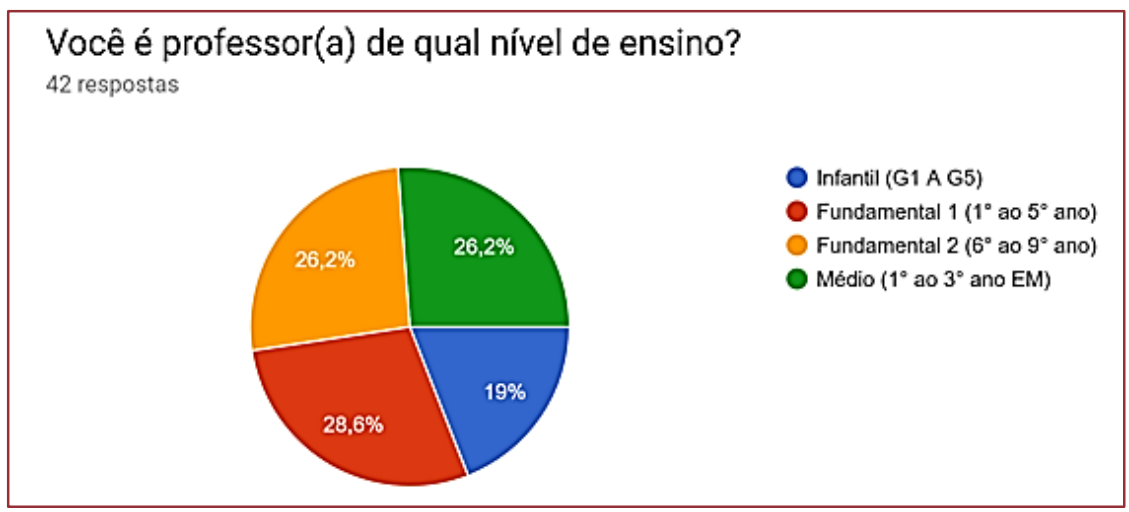


A maioria dos respondentes $(28,6 \%)$ é de professores do ensino fundamental $1\left(1^{\circ}\right.$ ao $5^{\circ}$ ano). A minoria (19\%) composta por professores da educação infantil (G1 a G5).

Indagados sobre o que para eles é a inclusão escolar, muitos responderam que consiste na prática do acolhimento as diferenças e adaptação curricular, como evidenciado na seguinte resposta: "É adequar a escola da melhor forma possível para receber e incluir no currículo pedagógico práticas que favoreçam o desenvolvimento da criança, respeitando seus limites do professor. Dentro das possibilidades de ensino e dos recursos que a escola oferece." Algumas respostas explicitaram pontos de vistas semelhantes, porém escritos de formas diferentes, como a inclusão atrelada a cidadania e a igualdade. A maior parcela dos respondentes evocou comentários com componentes positivos acerca da inclusão escolar, porém, outros teceram aspectos negativos sobre esta prática, como pode-se notar através da seguinte resposta: “Na atualidade, é um depósito de pessoas com dificuldades e que estão sendo enganadas, pois não desenvolvem habilidades minimamente necessárias para crescer social e intelectualmente."

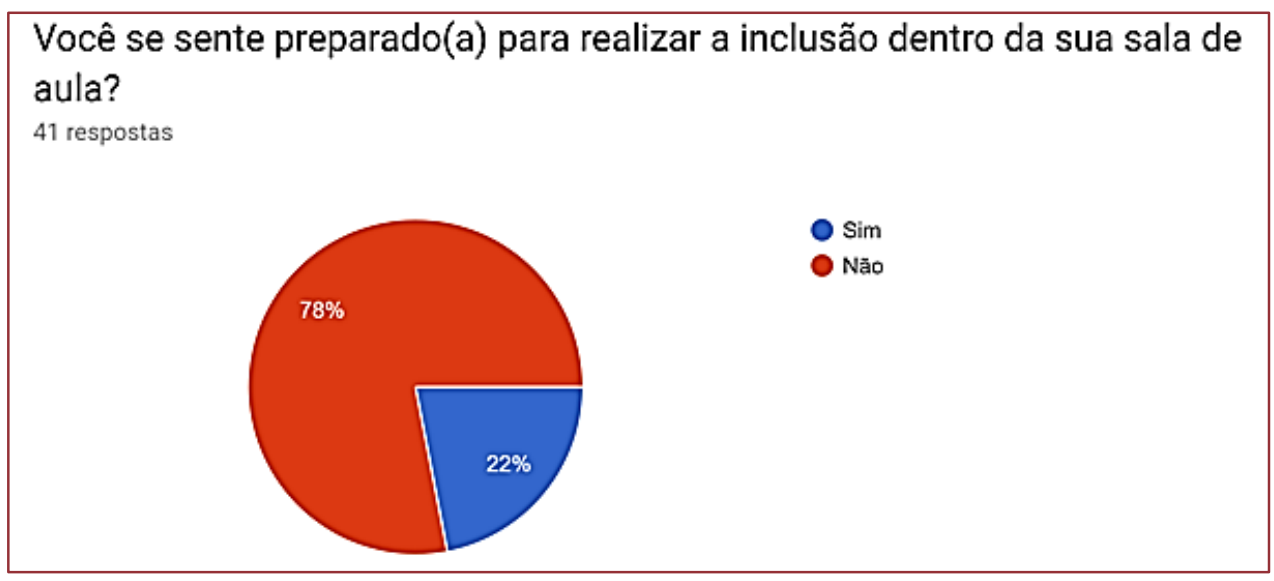

Quanto ao sentir-se preparados para praticar a inclusão dentro da sala de aula, a maioria respondeu que não se sente preparado para tal (78\%). A inclusão, explica Mantoan (2003) não pôde mais ser ignorada, nem marginalizada.

Foi questionado também quais as deficiências mais comuns dentro da sala de aula. Autismo foi o mais citado, seguido por transtorno do déficit de atenção e hiperatividade, dislexia e síndrome de Down. 78,6\% dos respondentes explicitaram que sentem dificuldade em trabalhar com pessoas com deficiência, e dentre essas dificuldades, as mais citadas foram: estrutura precária das escolas, falta de materiais (materiais escolares em geral), número insuficiente de profissionais, turmas numerosas e ausência de capacitação da equipe quanto ao trabalho com as pessoas com deficiência.

As adaptações curriculares também foram avaliadas através do questionário. 71,4\% dos participantes responderam que a escola na qual trabalham não realizam as devidas adaptações, evidenciando assim uma grande problemática pois este é um fator de extrema relevância para se realizar a inclusão escolar. $25,6 \%$ destacaram que existem adaptações nas escolas em que estão inseridos e que estas são caracterizadas por atividades adaptadas para a criança, como aumento da fonte, ausência de textos longos. Neste sentido, conforme apontam Nascimento, Scapim e Silveira (2003), as adaptações nos espaços que recebem alunos com deficiências não são suficientes para que a educação ocorra no nível desejado, pelo fato de existirem alunos com diversas demandas, singularidades e subjetividades. Então, é necessário que existam adaptações pedagógicas, comunicacionais e, principalmente atitudinais.

O questionário levantou também a discussão a respeito do profissional que auxilia o professor a trabalhar com a inclusão escolar. 57,1\% das pessoas afirmaram que não existe ninguém da equipe escolar que os ajuda a criar estratégias de inclusão. 42,9\% responderam que há alguém que os ampara neste processo. Questionados sobre a profissão deste indivíduo que desenvolve este tipo de trabalho, a maior parte destacou que consistem em pedagogos e psicólogos, e normalmente são coordenadores ou orientadores da escola. 0 suporte que estes profissionais fornecem para os professores também foi avaliado através do questionário, sendo em sua maioria, destacado como bom. 


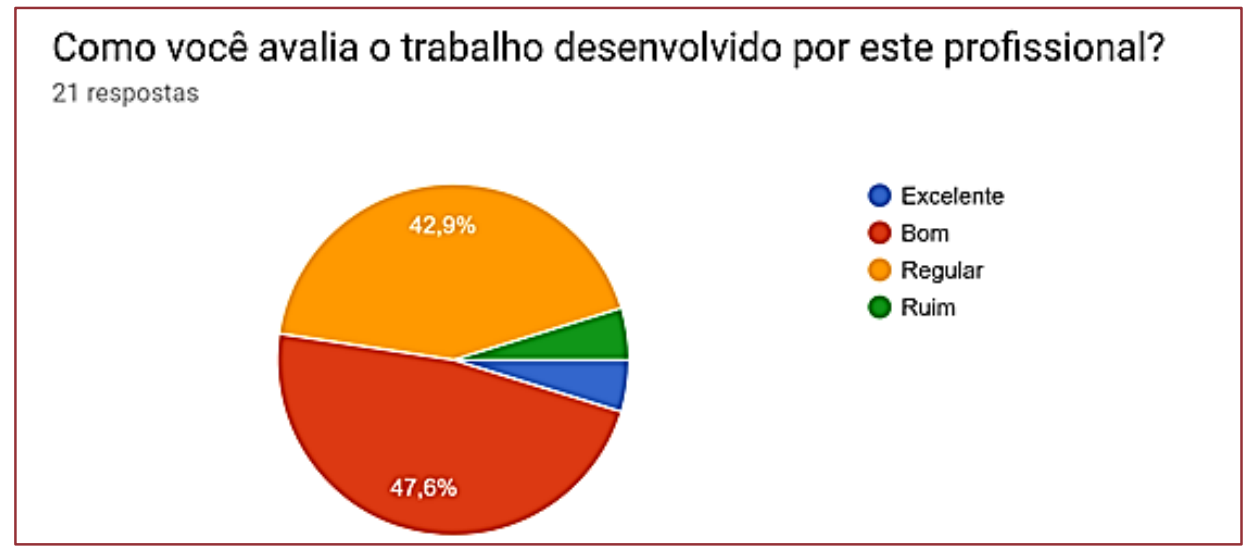

Indagados a respeito de como estas pessoas podem melhorar esta forma de contribuição, pode-se destacar esta resposta: "A psicóloga, muitas vezes, falta compreensão da dinâmica da sala de aula, conhecimento do que é possível fazer, também sobre os alunos de inclusão. Como não está em sala de aula, conhece pouco de suas potencialidades e dificuldades. A auxiliar também encontra dificuldade para saber lidar com essas crianças, desenvolver o seu potencial e não fazer por elas". A maioria pontuou, também, que necessita de capacitação, pois não se sentem preparados para atuar com esta demanda. Além disso, gostariam que os planos de aula fossem desenvolvidos em conjunto com estes profissionais, para assim conseguirem assegurar a inclusão de forma plena.

\section{CONSIDERAÇõES FINAIS}

Esse estudo objetivou analisar a atuação do psicólogo escolar na inclusão escolar da educação básica, assim como a forma que este tem desenvolvido as estratégias necessárias para a atuação dos professores em sala de aula com as pessoas com deficiência e as principais dificuldades encontradas por estes no processo de inclusão escolar.

Através da revisão bibliográfica, do questionário aplicado e das vivencias em 3 anos de estágio em escola constatou-se que a inclusão permeia mais o cenário utópico do que o real.

A falta de estrutura da maioria dos espaços escolares, aliada a má formação dos profissionais que circulam nestes ambientes, resultam não só em processos inclusivos defasados, mas principalmente em crianças adoecidas e incompreendidas.

O psicólogo escolar não tem desenvolvido um trabalho consistente nestes espaços. Falta tempo, momento para diálogo, capacitação, escuta. Os professores se sentem completamente sós no processo de inclusão escolar e na maioria das vezes não conseguem fornecer condições mínimas para que o aluno seja incluído na classe. Turmas lotadas, profissionais limitados, materiais escassos. Esta é a realidade de escolas encontradas por muitos professores que se deparam com a educação inclusiva.

É necessário que todos que promulgam a inclusão escolar, como os psicólogos escolares, se movimentem para participar ativamente do cotidiano de sala de aula com os professores, os auxiliando nos processos inclusivos e participando do desenvolvimento de atividades de classe.

\section{REFERÊNCIAS}

[1] Antunes, M.A.M. Psicologia e educação no Brasil: uma perspectiva histórica. In: Miranda, M. G. de (Org.), Psicologia: análise e crítica da prática educacional. Caxumbu: Anped, 2000.

[2] Antunes, M. A. M. Psicologia e educação no Brasil: um olhar histórico crítico. In: M. E. M. Meira \& M. A. M. Antunes (Orgs.), Psicologia Escolar: Teorias e Críticas. São Paulo: Casa do Psicólogo, 2003, p. 139-168.

[3] Antunes, M.A.M. Psicologia escolar e educacional: história, compromissos e perspectivas. Cadernos de Psicopedagogia, São Paulo, v.6, n.11, p.1-16, 2007. 
[4] Brasil, Lei № 13.146, DE 6 DE Julho de 2015. Dispõe sobre a Lei Brasileira de Inclusão da Pessoa com Deficiência. Disponível em: < http://www.planalto.gov.br/ccivil_03/_Ato2015-2018/2015/Lei/L13146.htm >. Acesso em: 15 set. 2018.

[5] Beyer, Hugo Otto. Inclusão e Avaliação na Escola: de alunos com necessidades especiais. $3^{\circ}$ Edição. Porto Alegre: Mediação, 2010.

[6] Dazzani, Maria Virginia. A Psicologia Escolar e a Educação Inclusiva: Uma Leitura Crítica. Psicologia, Ciência e Profissão, 2010, 30 (2), $362-375$.

[7] Guedes, Denyse Moreira. A importância da convenção internacional sobre os direitos das pessoas com deficiência como norma em nossa carta magna. Leopoldianum, Santos, n. 104/105/106, p. 85-98, 2012.

[8] Lima, Cárita Portilho. “O caminho se faz ao caminhar": Propostas de formação para uma atuação crítica em psicologia escolar e educacional. 2011. 160f. Dissertação (Mestrado) - Psicologia Escolar e Desenvolvimento Humano. Universidade de São Paulo - USP, São Paulo, 2011.

[9] Loureiro, M. C. da S. Psicologia escolar: mera aplicação de diferentes psicologias à educação? In: Patto, M.H. Introdução a Psicologia Escolar. São Paulo: Casa do Psicólogo, 1997, p. 449-458.

[10] Machado, Marcondes Machado; Almeida, Izabel; Saraiva, Luis Fernando de Oliveira. Rupturas necessárias para uma prática inclusiva. In: Anache, Alexandra Ayach; Silva, Lolete Ribeiro. Educação Inclusiva: Experiências Profissionais em Psicologia. Brasília: Conselho Federal de Psicologia, 2009. p. 21-37.

[11] Mantoan, Maria Teresa Égler. Inclusão Escolar: 0 que é? Por quê? Como fazer? $1^{\circ}$ Edição. São Paulo: Moderna, 2003.

[12] Martins, João Batista. A atuação do psicólogo escolar: multirreferencialidade, implicação e escuta clínica. Psicologia Em Estudo, Maringá, v. 8, n.2, p. 39-45, 2003.

[13] Mazzotta, Marcos J. S. História da educação especial no Brasil. In: Educação Especial no Brasil: História e Políticas Públicas. São Paulo: Cortez, 2003. Cap. 2, p. 27-49.

[14] Nascimento, Graciele Seleguim; Scapim, Kelly Cristina; Silveira, Cláudia Alexandra. Inclusão escolar e jogos cooperativos: uma possibilidade de atuação do psicólogo escolar no processo de socialização e integração. Revista da Spagesp - Sociedade de Psicoterapias Analíticas Grupais do Estado de São Paulo, São Paulo, v. 11, n. 2, p.51-63, 2010.

[15] Rabelo, Annete Scotti; Amaral, Inez Janaina de Lima. A formação do professor para a inclusão escolar: questões curriculares do curso de Pedagogia. In: Lisita, Verbena Moreira S. de S.; Sousa, Luciana Freire E. C. P. Políticas Educacionais, práticas escolares e alternativas de inclusão escolar. Rio de Janeiro: DP\&A, 2003. P. 209 - 223.

[16] Sanches, Isabel; Teodoro, António. Da integração à inclusão escolar: cruzando perspectivas e conceitos. Revista Lusófona de Educação, Lisboa, n.8, p.63-83,2006.

[17] Unesco (1994). Declaração de Salamanca e o Enquadramento da Acção - Necessidades Educativas Especiais. Adaptado pela Conferência Mundial sobre Necessidades Educativas Especiais: Acesso e Qualidade, Salamanca. 


\section{Capítulo 5}

Tecnologias digitais na atividade de inclusão na escola: Discussões em torno da fluência digital $e$ segurança docente

\section{Alaim Souza Neto \\ Maria Julia Pedroso \\ Nicoly Longaretti de Souza}

Resumo: Alguns autores do cenário educacional têm trazido à baila uma aproximação entre a Psicanálise e a Educação, ajudando-nos a trazer para o campo do currículo e da formação de professores, contribuições de Freud para a análise da profissão do professor como uma das tarefas complexas para sua exequibilidade (CODO, 1999; PEREIRA, 2011). A exemplo do contexto atual de inserção de tecnologias digitais (TD) na escola, o desafio está posto e discursos do "não saber" viram retórica permanente, além de motivos para o professor se justificar em relação ao que precisa ser assumido como compromisso na docência (SOUZA-NETO, 2015; 2016; MENDES, SOUZA-NETO, SEPTIMIO, 2016). Assim, este artigo emerge de pesquisa que problematiza os usos e desusos que os docentes fazem das TD no contexto da sala de aula como atividade de inclusão a partir de ações e atividades desenvolvidas no âmbito OPC - Observatório de Práticas Curriculares da UFSC. Metodologicamente, utilizamos de estudos de natureza etnográfica para investigar aspectos poucos explorados na perspectiva do professor: 0 primeiro, diz respeito ao relevo que as competências subjetivas podem se apresentar como essenciais ao exercício profissional; 0 segundo se refere ao conceito de fluência digital do professor, entre os já consagrados saberes pedagógicos (SHULMAN, 1987; 1986). Esses aspectos foram as principais contribuições para na problematização do seguinte objeto: a necessidade de considerarmos as competências subjetivas para o exercício da fluência digital do professor.

Palavras-chave:Tecnologia Digital; Formação de Professores; Atividade de inclusão. 


\section{INTRODUÇÃO}

Nenhum professor gosta de ter consciência, muito menos expor seus truques de manipulação de alunos, de seus tiques, suas manias, seus deslizes verbais, suas cóleras, seus momentos de sadismo ou de pânico, suas incoerências, suas ambivalências, suas despolitizações, suas reações de defesa e embaraço, de fragilidade e dúvida. (PEREIRA, 2011, p. 42).

Alguns autores brasileiros têm trazido à baila uma aproximação entre a Psicanálise e a Educação, ajudando-nos a trazer, para o campo do currículo e da formação de professores, contribuições de Freud para a análise da profissão do professor como uma das tarefas complexas para sua exequibilidade (CODO, 1999; PEREIRA, 2011). Tais complexidades carregam a ideia de que todo ato educativo traz em si o empreendimento do fracasso dada a "paixão humana pela ignorância", além de o fato de sê-lo relacional, imprevisível e contingente. Assim, o exercício da docência, na construção narcísica da profissão, parece a cada dia se afastar mais do ato de "aprender" e concentrar-se exclusivamente no "ensinar" (SOUZA-NETO, 2015; 2016a; 2016b) na tentativa de cumprir a gramática escolar em que pese a transmissão do conhecimento.

Nesse contexto, poderíamos questionar qual conhecimento a transmitir na escola, se o poderoso ou dos poderosos? (YOUNG, 2007). Entretanto, o que nos interessa é compreender porque a exigência do saber se tornou característica tão central da atividade docente. A consciência dessa exigência faz parte do rol das subjetividades dos professores, e muitas vezes, carrega consigo o sofrimento pedagógico pela falta de segurança em relação ao seu labor. Como afirma Pereira (2011), nenhum professor gosta de abrir mão da "arrogância narcísica" que mascara em certa medida, por exemplo, sua falta de conhecimento. É em torno desse objeto, o não saber, em especial, usar as TD no contexto escolar, que nos atemos neste texto.

\subsection{BJETIVOS E METODOLOGIA}

Foi em campo, desde 2012, com o objetivo de investigar como os professores se relacionavam com as tecnologias digitais (TD) em suas práticas escolares que temos nos deparado com alguns achados de pesquisa que não tínhamos nos dado conta: as subjetividades docentes para o seu uso ou não uso. Assim, temos nos concentrado em pesquisas com aspectos ainda poucos explorados na perspectiva do professor, a respeito da integração das TD na prática docente. A saber, dois aspectos nos movem em nossas investigações: o primeiro, diz respeito ao relevo que as competências subjetivas podem apresentar para o exercício profissional docente, como: não saber, segurança, consciência, motivação, autoconfiança, desejo de inovar; o segundo se refere ao conceito de fluência digital que apresentamos em algumas pesquisas (SOUZA NETO 2015; 2016; MENDES, SOUZA-NETO, SEPTIMIO, 2016; 2016b, NETO e LUNARDI-MENDES, 2017), este apontado na contemporaneidade digital como um dos saberes fundamentais para a integração pedagógica das TD no contexto escolar, entre os já consagrados saberes pedagógicos e saberes da disciplina.

Esses dois aspectos foram as principais contribuições para a defesa de intervenção que propomos aos cursos de formação de professores sobre a integração de tecnologias no contexto escolar: a necessidade de considerarmos as competências subjetivas para o exercício da fluência digital do professor. Tentar compreender como os professores se relacionam com os 'saberes que não dominam', como mobilizam ou não o desejo de mudança, como enfrentam um novo desafio e como se conscientizam para a necessidade de avançar seu processo de formação, são questões ainda latentes para compreendermos os modos como os professores integram as TD na escola.

Dessas competências subjetivas docentes, tem nos chamado muito nossa atenção, uma delas: a mobilização que o não saber assume na atividade docente. Esse não saber tem emergido em nossas pesquisas (NETO, 2015; 2017), bem como em pesquisa que estamos envolvidos atualmente no Grupo de Pesquisa OPC da UFSC, com forte ênfase em discursos docentes, como "[...] eu não estou preparado para usar essas tecnologias", "não tive formação para o uso", "não uso porque não sei usar" (DADOS DE CAMPO). A exemplo do contexto atual de inserção de tecnologias digitais (TD) na escola, o desafio está posto na escola e discursos do "não saber" viram retórica permanente, além de motivos para o professor se justificar em relação ao que precisa ser assumido como compromisso na atividade docente (SOUZANETO, 2015; 2016; MENDES, SOUZA-NETO, SEPTIMIO, 2016). Assim, este trabalho trata de conclusões parciais da pesquisa que está em andamento.

Metodologicamente, inspiramo-nos em estudos de natureza etnográfica para realizar esta investigação exploratória em duas escolas públicas da rede pública da região da grande Blumenau/SC em que os 
sujeitos da pesquisa são docentes do ensino fundamental II. A pesquisa tem como objetivo investigar as práticas escolares desses professores, procurando identificar entre a integração que fazem ou não das TD, quais são os impedimentos, obstáculos ou barreiras dessa integração para a aprendizagem dos alunos, atentando-se, sobretudo mais aos aspectos pedagógicos que tecnológicos. Quanto aos instrumentos de pesquisa, temos feito uso de questionários, diários de campo, além de narrativas autobiográficas com os professores.

\section{INTEGRANDO OU NÃO AS TECNOLOGIAS DIGITAIS NA ESCOLA}

É notório que, nos dias atuais, as Tecnologias Digitais se tornaram essenciais para a vida em sociedade e para a disseminação e compartilhamento de informações, tendendo a uma efetividade ainda maior. Existem algumas maneiras de tratar o uso de tecnologias como meio de inclusão, mas neste estudo, atemonos ao espectro da inclusão das tecnologias digitais no contexto escolar como possibilidade de inclusão digital, mas, sobretudo, social. Nessa ótica, dos resultados parciais que obtivemos, os achados de pesquisa que têm nos chamado a atenção são quatro (04):

0 primeiro deles, integração que os professores fazem das TD em suas práticas escolares, localizamos os usos mais ou menos frequentes, bem como os desusos que são feitos das TD pelos professores. Na vida pessoal, consideram-se como usuários moderados, fazem mais uso do celular e notebook e, predominantemente, usam as TD para se entreter, comunicar-se e navegar pela internet. Ainda em casa, usam para digitar textos, pesquisar e criar apresentações, de forma limitada e pouco pedagógica. No contexto escolar, a maioria dos professores se considera pouco usuário, faz mais uso do projetor de multimídia, computador e notebook. Além disso, usa mais como recurso de exposição de conteúdos em detrimento a interação, colaboração, como também para entreter e/ou motivar os alunos como recurso de atenção e concentração pedagógica.

Destaca-se o uso acentuado das TD para apenas ocupar o tempo da aula, sem muita clareza dos objetivos de uso e distanciado do ensino dos conteúdos curriculares, servindo mais como inovação tecnológica e muito menos como inovação pedagógica ou curricular. Quanto aos usos menos frequentes, está o uso das TD na sala de aula com os alunos para ensino dos conteúdos curriculares, bem como pouco uso para planejar as aulas, criar novas estratégias de avaliação. Além disso, alguns dados revelam o completo desuso (não uso) das TD em práticas de alguns professores, por acreditarem que elas não têm qualquer potencial e porque também não sabem como usá-las.

É possível afirmar que, dos diferentes modos de usar ou não as TD, existem contraditórias lógicas de uso na vida pessoal e na cultura escolar. De qualquer forma, pode-se dizer que em qualquer um dos contextos, as TD se restringem à perspectiva de uso limitada, simples, inconsistente, instrumental, periférica e operatória. Todavia, na escola estas perspectivas são enfatizadas e parecem configurar a impressão de que os professores não sabem usá-las de modo algum em função das exigências pedagógicas que a cultura escolar demanda para cumprir a sua função social mais predominante: o ensino dos conteúdos curriculares.

Desse modo, emergem os sentimentos de falta de confiança e insegurança profissional frente ao desafio de não saber usar as TD com os alunos, muito caracterizado pela falta de apoio técnico e pedagógico. Junto ao não saber, justificam o não uso porque as TD desestabilizam a sua identidade e autoridade docente ou até mesmo porque dá mais trabalho ao professor. Além disso, por que ocupam mais tempo da atividade docente, bem como porque alteram os tempos, espaços e saberes que já estão acostumados.

O segundo deles, trata-se da insegurança profissional dos professores para lidar com as TD na escola, principalmente, na sala de aula e frente aos alunos em função de vários impedimentos. 0 sentimento de insegurança emergiu em meio a outros, como: medo, desconforto, desconfiança, desinteresse, falta de entusiasmo, confiança e não-saber. São sentimentos relacionados ao medo de mostrarem que há coisas que não sabem fazer ou conhecimentos que não dominam. Eles acabam funcionando como barreiras ou obstáculos paralisantes de qualquer relacionamento pedagógico com as TD e resultantes de aspectos psicológicos internos ao professor que acabam cumprindo o papel de impedimentos.

Destarte, os professores enfatizaram muito que sua insegurança está relacionada, principalmente, à falta de saber ou de apoio técnico e pedagógico, idealizada na figura de alguém que esteja ao seu lado como um vigilante ou zelador técnico a fim de resolver todos os problemas que surgirem relacionados aos usos das TD. Destacam que as TD têm que estar à disposição do professor com tudo montado e pronto para uso, pois sua única função é ensinar os conteúdos, ou seja, reconhecem como seus saberes legítimos de sua profissão apenas os pedagógicos (didáticos, curriculares, etc.) e aqueles relacionados ao conteúdo escolar. 
0 terceiro deles se refere à fluência digital. Defendemos como um saber a ser problematizado nas futuras formações que objetivem o uso pedagógico das TD baseada não só no seu acesso, mas em experiências de uso. Essa afirmação está subsidiada pelas observações de campo em torno de algumas experiências de uso das TD, de um professor que destaca em relação aos demais pelo nível de sua fluência digital. Foram experiências de ensino da matemática feitas de modo mais interativo com o envolvimento dos alunos e com notório aumento do interesse e motivação dos alunos para aprender os conteúdos escolares, bem como aumento da pré-disposição e curiosidade do professor para ensinar.

Se num primeiro momento o uso pedagógico das TD pode depender dos professores, num segundo momento a questão parece ser a de saber ou não-saber como executar diferentes práticas escolares. Pensando no modelo proposto por Sandholtz, Ringstaff e Dwyer (1997), nossa hipótese é que na escola pesquisada a cultura escolar está na transição da fase que vai da adoção das TD para a adaptação delas na prática. Foi em meio a essa transição, que percebemos o início de um movimento docente. Assim, o primeiro e imediato desafio seja ter pequenas atitudes em meio à solidez e rigidez das práticas e nos preparar para a flexibilidade, colaboração e personalização que as TD podem promover. Por isso, vemos na fluência digital um impulsionador para pensar essas transformações que buscamos não só porque podem promover diferentes estratégias didáticas aos alunos, mas porque podem conduzir o professor para um processo de aprender com o aumento da sua motivação profissional na medida em que proporciona mais segurança e fortalecimento da sua identidade docente.

Em síntese, dos usos da integração das TD, podemos afirmar que as tecnologias parecem servir mais como facilitadoras e promotoras da redução do seu esforço laboral para ministrar as aulas ou mesmo redução do tempo de atenção pedagógica dedicada aos alunos do que de fato como estratégia didática para aprender conteúdos escolares. De qualquer modo, nos quatro achados a discussão em torno do não-saber usar as TD continua sendo um grande impedimento ao professor.

\section{COMPETÊNCIAS SUBJETIVAS}

Entre os motivos de resistência às TD, percebemos nos discursos que emergem questões relacionadas ao medo, ao desconforto, à falta de motivação, confiança, interesse, entusiasmo, curiosidade, atitude e de consciência para mudar e pensar outras possibilidades de ensino com tecnologias diferentes do quadro, giz, caderno, etc. Todavia, o não-saber usar as TD tem assumido papel protagonista entre essas resistências à integração das TD no contexto escolar.

Diante de novos desafios, como as propostas de uso de TD em sala de aula, os discursos do "não saber" são uma retórica constante. Ficar atento a como o professor lida com um "não saber", como mobiliza ou não o desejo de mudança, como enfrenta um novo desafio, são questões essenciais para compreendermos os modos como ele usa a tecnologia ou como lida com um novo desafio, como as propostas de inclusão escolar. Obviamente toda essa dimensão individual é contingenciada e construída por uma dimensão coletiva, no entanto, é ela também uma "ancoragem" para o professor subsumir o seu não saber.

Parece que é na contramão de tudo isso, que temos que operar. Como bem destaca Pereira (2011, p. 42): É fundamental acordar desse torpor falacioso dos manuais médio-pedagógicos que, se bem ou mal nos orientam, não podem determinar nossos atos, nem nos impor uma rotina acéfala mediante as urgências complexas e ambíguas de nossa prática. Para isso não há preparação prévia suficiente, mas uma formação contínua e politizada, bem ao sabor dos acontecimentos ou insurreições do real. Podemos estranhar nossa rotina, nossos esquemas de base e nossa adesão às prescrições? Podemos desnaturalizar tanto o imperativo do "ter" do discurso capitalista quanto os saberes prévios do discurso da universidade, isto é, demitir-se da impotência e consentir a impossibilidade? Ou seja, não há formação prévia que dê conta sozinha de garantir um uso pedagógico adequado das tecnologias digitais ou sucesso em propostas de inclusão. Estamos diante da necessidade de construirmos o desejo para os docentes se ocuparem disso, e no dizer de Pereira (2011), se for verdade que ensinar é construir saberes artesanalmente, essa construção cotidiana precisa encontrar espaços de fruição.

Especificamente, no caso das TD, em tempos em que as novidades tecnológicas são diárias, não podemos ser ingênuos e imaginar que um tipo de formação específica ajudaria o professor nessa empreitada. A aposta é, no rol de competências docentes, investir cada vez mais na imprevisibilidade da sua tarefa. Ter consciência de que estamos diante de profissionais do impossível é um dos caminhos para enfrentar os desafios de aprender e ensinar no imprevisto.

Souza-Neto (2015), no conjunto de suas investigações, afirma que não são poucos os aspectos que impedem que o professor tenha voluntariamente uma pré-disposição para uma tomada de consciência 
esclarecida sobre como, por que e para que usar as tecnologias digitais com os alunos, justificada pela falta, principalmente, de segurança profissional em função do despreparo técnico/tecnológico, caracterizado, grosso modo, como falta de fluência digital. A respeito dessa ideia de conceber a fluência digital apenas como falta de formação técnico-instrumental, também tem sido apontada nas pesquisas "[...] como entrave para práticas pedagógicas inovadoras, a saber, a insegurança dos professores no uso das tecnologias digitais [...]." (CERNY; ALMEIDA; RAMOS, 2014, p. 1342).

Percebemos que a insegurança está articulada ao "não saber". Em campo, a insegurança dos professores se manifestou nos discursos dos professores, no caso das tecnologias, muito atrelada à formação que é cada vez mais generalista e menos específica. Os professores expressam que em alguma medida uma "formação especializada" lhes garante algum tipo de segurança. Assim, o "não saber" se manifesta no professor pela insegurança de imaginar que os alunos podem "saber mais" que ele. Suas angústias e medos se revelavam em discursos, como:

O que vou fazer na hora que me perguntarem? Me apavoro com a ideia de eles ficarem perguntando e eu não saber responder. Como é que vou fazer com essas dificuldades? É uma insegurança muito grande para o professor. Eu tinha que me preparar porque não posso ficar lá na frente passando vergonha, né!! Tem até aqueles alunos que sabem mais que o professor. (DADOS DE CAMPO).

Parece que no caso das tecnologias se explicita o desequilíbrio que o "não saber" pode trazer para relação professor-aluno. Tem-se o fato de os alunos usarem as tecnologias mais que os professores o que provoca, na maioria das vezes, uma atitude de negação do próprio docente que não queria se "[...] deparar com o aluno que está bem preparado para lidar com tecnologias, que sabe mexer, enquanto eu não estou sabendo." (DADOS DE CAMPO).

Temos ciência de que os alunos não estão mais preparados que os professores para o uso das tecnologias, mas não negamos a ideia de que eles se encontram mais preparados para conviver com a cultura digital e, assim acabam se inserindo com mais fluência num movimento sociocultural em que apenas exploram-nas com mais curiosidade e agilidade, sem muitos medos e receios dos novos instrumentos que nos permeiam.

Ainda sobre a insegurança, os dados demonstram que os professores têm mais confiança em relação ao domínio do conteúdo disciplinar e da didática para ensinar os alunos, contudo, nem todos têm a mesma confiança quando o assunto é o uso das tecnologias para ensinar os conteúdos escolares. É em torno desses aspectos ou "barreiras" como afirmam Infante e Nussbaum (2010) que problematizamos a atitude e a motivação do professor para usar as TD na escola, pois essa problematização se acentua quando percebemos que "[...] para além das 'concepções pedagógicas' dos professores, no caso dos factores pessoais determinantes do uso, parecem ser as 'atitudes' e a confiança, os factores que parecem salientar" (COSTA et al., 2008, p. 517).

\section{CONCLUSÃO}

Embora algumas pesquisas abordem o uso das TD para além da ideia de apoio ou suporte às aulas (ALMEIDA; VALENTE, 2011), nossa pesquisa revela que entre os professores é recorrente encontrar em seus discursos a ideia de que a integração das TD na escola é ainda limitada porque os professores afirmam não-saber o que fazer e como fazer, instrumentais porque priorizam os aspectos técnicos em detrimento dos pedagógicos e periféricos porque apenas tangenciam as práticas educativas com estratégias de motivação dos alunos e desconectados do ensino dos conteúdos escolares.

Em síntese, os professores integram as TD apenas em práticas sociais da sua vida pessoal/social, de forma predominante para uso como meio de entretenimento e comunicação. Na escola, a integração das TD não tem a mesma lógica, já que é mais pedagógica com necessidade de atendimento aos objetivos de ensino do currículo. Assim, na escola, os professores ainda fazem pouco uso das TD como instrumentos mediadores de suas práticas pedagógicas. A integração das TD, na sua maioria, é pouco consistente para a cultura escolar e, por isso talvez a ideia de existir uma diversidade de apropriação tecnológica: há os que usam aproveitando mais das potencialidades das tecnologias como a interação, há aqueles que usam de modo mais simples, limitado e instrumental, existem aqueles que pouco usam e com muito receio e insegurança e, por fim, uma minoria que "desusa" (não usa). 


\section{REFERENNCIAS}

[1] Almeida, Maria Elizabeth Bianconcini; Valente, José Armando. Tecnologias e currículo: trajetórias convergentes ou divergentes? São Paulo: Paulus, 2011.

[2] Cerny, Roseli Zen; Almeida, José Nilton de; Ramos, Edla. Formação continuada de professores para a cultura digital. Revista e-Curriculum, São paulo, n. 12, v. 2, p. 1331-1347, maio/out. 2014.

[3] Codo, Wanderlei (Coord.). Educação: Carinho e Trabalho. Petrópolis, RJ: Vozes/Brasília: CNTE: Universidade de Brasília. Laboratório de Psicologia do Trabalho, 1999.

[4] Costa, Fernando Albuquerque et al. Competências TIC: estudo de Implementação. Lisboa: Gepe, 2008. (Plano Tecnológico de Educação, v. 1).

[5] Mendes, Geovana Mendonça Lunardi; Souza Neto, Alaim; Septimio, Carolline. O “Não Saber" Como Retórica Constante: Aproximações entre os observatórios de educação especial e de políticas de inserção de tecnologia. Revista Teias, Rio de Janeiro, v. 17, n. 46, p.90-109, set. 2016.

[6] Pereira, Marcelo Ricardo. Avesso de uma paixão. In: Revista Espaço Acadêmico. n. 120, maio de 2011. p. 36-

44

[7] Sandholtz, Judith Haymore; Ringstaff Cathy; Dwyer, David C. Ensinando com tecnologia: criando salas de aula centradas nos alunos. Trad. Marcos Antônio Guirado Domingues. Porto Alegre: Artes Médicas, 1997.

[8] Shulman, L. S. Those who understand: knowledge growth in teaching. Educational Researcher, Washington, US, v. 15, n. 2, p. 4-14, 1986

[9] Shulman, L. S. Knowledge and teaching: foundations of the new reform. Harvard Educational Review, Cambridge, US, v. 57, n. 1, p. 1-22, 1987.

[10] Souza Neto, Alaim. Do aprender ao ensinar com as tecnologias digitais: mapeamento dos usos feitos pelos professores. Tese (Doutorado) - Universidade do Estado de Santa Catarina, Centro de Ciências Humanas e da Educação, Programa de Pós-Graduação em Educação, Florianópolis, 2015.

[11] Souza Neto, Alaim. Do aprender ao ensinar com as tecnologias digitais: discussões atuais aos professores. São Paulo: Pimenta Cultural, 2016.

[12] Souza Neto, Alaim; Mendes, Geovana Mendonça Lunardi. Os usos das tecnologias digitais na escola: discussões em torno da fluência digital e segurança docente. Revista E-curriculum, [s.l.], v. 15, n. 2, p.504-523, 30 jun. 2017. Portal de Revistas Puc SP.

[13] Young, Michael. Para que servem as escolas?. Educ. Soc., Campinas, v. 28, n. 101, p. 1287-1302, dez. 2007. 


\section{Capítulo 6}

\section{Relações educadores-educandos na educação de jovens e adultos: Aprendendo a "Pedagogia da autonomia" na Práxis}

\section{Ivani Soares}

Resumo: 0 tema deste trabalho é a aplicabilidade das relações educadores-educandos, da obra Pedagogia da Autonomia, de Paulo Freire, na Educação de Jovens e Adultos EJA. De acordo com a obra citada, a prática de um diálogo político-pedagógico calcado em virtudes éticas pode estabelecer condições de modificar as formas de ver o mundo, de inter-relacionar-se e de articular-se com ele. 0 contexto de estudo foi a Escola Municipal de Ensino Fundamental Antônio Fued Kalil, localizada na cidade de Bagé, no RS. 0 problema de pesquisa perguntou se "As relações entre educadores e educandos influencia diretamente a forma de aprender dos estudantes jovens e adultos modificando sua forma de ver o mundo e realcionar-se com ele." A hipótese de pesquisa era que "As relações entre educadores e educandos influencia a forma de ver o mundo e realcionar-se com ele, bem como influencia a forma de aprender na Educação de Jovens e Adultos - EJA." Quanto à justificativa, esse estudo objetivou demonstrar que, na Educação de Jovens e Adultos - EJA, a prática de um diálogo político-pedagógico calcado em virtudes éticas pode estabelecer condições de modificar as formas de ver o mundo, de inter-relacionar-se e de articular-se com ele. Também, investigou, entre os estudantes que já cursaram e os que estão cursando a EJA na escola citada, qual é a importância da alfabetização e o que mudou no dia a dia deles depois da alfabetização. 0 objetivo geral foi "Estudar e analisar a aplicabilidade da Pedagogia da Autonomia, de Paulo Freire, junto aos estudantes da EJA." Como metodologia, utilizou-se a análise da legislação pertinente à Educação de Jovens e Adultos, a pesquisa bibliográfica qualitativa (tendo como base a obra Pedagogia da Autonomia, de Paulo Freire); a pesquisa interpretativa de uma dada realidade; e a análise documental; também, foram feitas entrevistas diretas com docentes e discentes da Escola Fued Kalil, sendo assim caracterizada como uma pesquisa exploratório-descritiva. 0 principal autor utilizado na pesquisa foi Paulo Freire e suas obras, em especial a obra Pedagogia da Autonomia. Os outros autores estudados foram Carlos Alberto Torres, Maria Fani Scheibel e Titiva Cardona Leal. Com a processualidade da pesquisa, os constructos epistemológico-políticos levaram a concluir que as relações entre educadores e educandos influencia a forma de aprender na Educação de Jovens e Adultos - EJA e que, mais do que disciplinas curriculares, é preciso construir juntos os saberes, buscar o pensar certo, e o pensar certo, para Freire, significava procurar descobrir e entender o que se acha mais escondido nas coisas e nos fatos que nós observamos e analisamos.

Palavras-Chave: alfabetização, EJA, Paulo Freire, autonomia. 


\section{PALAVRAS INICIAIS: O CONTEXTO DO PENSAR E DO FAZER EDUCAÇÃO DE JOVENS E ADULTOS.}

Este trabalho foi apresentado na conclusão da pós-graduação em Educação, Diversidade e Cidadania, da Faculdade Educacional da Lapa - FAEL, em outubro de 2017; após foi adaptado para apresentação no Seminário Nacional Diálogos com Paulo Freire ${ }^{7}$. Apresentamos os constructos epistemológico-políticos do estudo sobre o tema das relações entre educadores e educandos, na Educação de Jovens e Adultos - EJA, sob a ótica de Paulo Freire, tendo como base a obra Pedagogia da Autonomia, segundo a qual a prática de um diálogo político-pedagógico calcado em virtudes éticas pode estabelecer condições de modificar as formas de ver o mundo, de inter-relacionar-se e articular-se com ele. 0 contexto de estudo foi a Escola Municipal de Ensino Fundamental Antônio Fued Kalil, de Bagé/RS.

O trabalho foi estruturado da seguinte forma: inicialmente, abordamos a formalização da EJA como política pública e fizemos uma retrospectiva histórica das Políticas Oficiais de alfabetização de adultos já efetivadas no País. Na sequência, falamos sobre o método Paulo Freire; sobre os planos Nacional, estaduais e municipais de educação; e sobre a Escola Antônio Fued Kalil. Apresentamos, então, os resultados do estudo propriamente dito, relacionando os conceitos da obra Pedagogia da Autonomia, de Paulo Freire, com os depoimentos colhidos e concluímos referenciando as percepções a que foi possível chegar com a realização do trabalho.

O objetivo geral foi analisar a aplicabilidade da Pedagogia da Autonomia, de Paulo Freire, junto aos alunos da EJA da Escola Municipal de Ensino Fundamental Antônio Fued Kalil. A justificativa para a investigação veio da necessidade de saber se, na Educação de Jovens e Adultos - EJA, a prática de um diálogo políticopedagógico calcado em virtudes éticas poderia estabelecer condições de modificar as formas de ver o mundo, de inter-relacionar-se e articular-se com ele e, ainda, investigar por qual motivo as pessoas voltam a estudar e o que muda no cotidiano delas após a alfabetização. Especificamente, delimitamos o objeto de estudo na análise da aplicabilidade da Pedagogia da Autonomia de Paulo Freire junto aos educandos da EJA; na importância das relações afetivas no processo de alfabetização de adultos; nos motivos que trazem as pessoas adultas (de volta) para a escola e nas auto(trans)formações ocorridas no cotidiano delas depois da alfabetização.

A metodologia utilizada no trabalho foi a pesquisa da legislação vigente; a pesquisa bibliográfica qualitativa (utilizando como base a obra Pedagogia da Autonomia, de Paulo Freire); a análise de contexto e entrevistas diretas com docentes e discentes da Escola Fued Kalil, sendo assim, também, uma pesquisa exploratório-descritiva.

\section{FORMALIZAÇÃO DA EDUCAÇÃO DE JOVENS E ADULTOS: EJA COMO POLÍTICA PÚBLICA.}

A educação como direito de todos e dever do Estado está prevista na Constituição Federal de 1988, que, em seu artigo 205, informa:

Art. 205 - A educação, direito de todos e dever do Estado e da família, será promovida e incentivada com a colaboração da sociedade, visando ao pleno desenvolvimento da pessoa, seu preparo para o exercício da cidadania e sua qualificação para o trabalho.

Os artigos 198, 204 e 206 da Constituição Federal de 1988 deram origem à criação de conselhos de políticas públicas no âmbito da saúde, da assistência social e da educação nos três níveis de governo. No artigo 206 são explicitados os princípios base para ministrar o ensino. Dentre eles, no inciso primeiro, figura a garantia da igualdade de condições para o acesso e a permanência na escola.

0 artigo 214, por sua vez, define que será a lei quem estabelecerá o plano nacional de educação que irá assegurar o ensino em seus diversos níveis, etapas e modalidades de forma a conduzir, dentre outros fatores, à erradicação do analfabetismo e à universalização do atendimento escolar.

Art. 214. A lei estabelecerá o plano nacional de educação, de duração decenal, com o objetivo de articular o sistema nacional de educação em regime de colaboração e definir diretrizes, objetivos, metas e estratégias de implementação para assegurar a manutenção e o desenvolvimento do ensino em seus diversos níveis, etapas e modalidades por meio de ações integradas dos poderes públicos das diferentes esferas federativas que conduzam a: (...) (Redação dada pela Emenda Constitucional no 59, de 2009).

\footnotetext{
7 Período: 24 e 25 de novembro de 2017. Tema: Democracia, Escola, Campo e Cidade - Estratégias de Intervenção Social e Política na Pedagogia da Libertação.
} 
Neste contexto está inserida a EJA - Educação de Jovens e Adultos. 0 artigo 32 da Lei de Diretrizes e Bases da Educação (LDB no 9394/96) informa que o ensino fundamental deverá ter por objetivo a formação básica do cidadão, mediante o desenvolvimento de algumas capacidades lá explicitadas. No artigo 37 desta lei, fica claro a quem se destina a educação de jovens e adultos, ou seja, "àqueles que não tiveram acesso ou continuidade de estudos no ensino fundamental e médio na idade própria". Este artigo ainda assegura a essas pessoas oportunidades educacionais apropriadas e gratuitas nos sistemas de ensino, consideradas as características do alunado, seus interesses, condições de vida e de trabalho.

A formação inicial e continuada de profissionais para a Educação de Jovens e Adultos, de acordo com o artigo 17 da Resolução no 1, de 5 de julho de 2000, do Conselho Nacional de Educação (CNE), terá como referência as Diretrizes Curriculares Nacionais para o Ensino Fundamental e para o Ensino Médio e as Diretrizes Curriculares Nacionais para a formação de professores. Ainda de acordo com o parágrafo único do artigo 5ํo dessa Resolução, a oferta dessa modalidade de ensino deve considerar as situações, os perfis e as faixas etárias dos estudantes.

A EJA - Educação de Jovens e Adultos - está inserida no conceito de Políticas Públicas, sobre o qual ainda não existe consenso na literatura, por ser este um campo recente da ciência política, mas que podem ser entendidas como sendo as atividades dos governos que influenciam a vida dos cidadãos.

A formalização de políticas públicas inclusivas (como é o caso da EJA) deixa claro o reconhecimento, pela sociedade e pelos poderes públicos, do direito à educação. 0 analfabetismo é o reverso da cidadania e uma violação ao princípio constitucional da igualdade. A EJA é fator de resgate do princípio da dignidade da pessoa humana.

\subsection{MEMÓRIAS DE AÇõES NA EDUCAÇÃo POPULAR: POLÍTICAS OFICIAIS DE ALFABETIZAÇÃo DE ADULTOS JÁ EFETIVADAS NO PAÍS.}

A partir da década de 1960 várias ações de alfabetização de adultos foram efetivadas no Brasil. Dentre elas, destacam-se:

$\checkmark \quad$ o Movimento de Educação de Base - MEB (1961 até hoje) - criado através do Decreto 50.370/1961, por iniciativa da igreja católica, previa uma colaboração do Governo Federal com a Conferência Nacional de Bispos do Brasil - CNBB. Inicialmente, objetivava ser um conjunto de ensinamentos destinados a promover a valorização do homem e o soerguimento das comunidades; no entanto, com o passar do tempo e após o Golpe Militar passou a ser entendido como o ato de aprender a comer bem, defender sua saúde, manter boas relações com os semelhantes e integrar-se no quadro de uma sociedade justa. Em alguns estados o programa encerrou-se em 1966;

$\checkmark \quad$ o Movimento de Cultura Popular - MCP (1960 a 1964) - movimento ligado à prefeitura de Recife, tinha o apoio de Miguel Arraes e Paulo Freire. Utilizava os círculos de cultura para alfabetizar por meio de grupos de debates, que serviam para elucidar as situações problema vivenciados no cotidiano dos educandos. Eram cinco alunos no início, dois desistiram e os demais, em cerca de 30 dias, estavam lendo pequenos textos. Por falta de recursos para chegar a outros estados, o movimento restringiu-se ao Recife e ao Rio grande do Norte. Em 1964 foi extinto, por causa do Golpe Militar, e alguns de seus membros foram presos, outros foram exilados;

$\checkmark \quad$ o Centro Popular de Cultura - CPC (1961 a 1964) - fundado pela União Nacional dos Estudantes, artistas e intelectuais (UNE), tinha como objetivo levar a cultura às classes mais desfavorecidas da sociedade e utilizava peças teatrais para atingir este objetivo. O CPC teve sua sede incendiada em 1964;

$\checkmark \quad$ a Campanha de Educação Popular - CEPLAR (1961 a 1964) - criada pelo governo estadual da Paraíba, utilizava o Método Paulo Freire em larga escala, tendo como tema central a realidade brasileira, objetivando conscientizar as pessoas. Considerado um método subversivo e comunista, acabou sendo extinto.

A Campanha Nacional de Alfabetização, pensada por Goulart, contou com auxílio de Paulo Freire, que, na década de 60, desenvolveu um método de alfabetização pela construção do conhecimento de forma conjunta pelo educador e pelo educando. Uma educação de dentro para fora, que levava à libertação do homem pelo conhecimento. A realização desse intento foi impedida pelo golpe de 64 .

Surgiu, então, no Brasil, como movimento de alfabetização de adultos, o projeto denominado "MOBRAL" (1967 a 1985), criado pela Lei número 5.379/1967. Diferente da pretensão de Paulo Freire (ensino como ato coletivo de caráter crítico e socializador que analisasse o contexto político, social e individual de cada um), o objetivo do MOBRAL, cujo controle total do que seria ensinado era dos militares, era o de levar 
adultos a ler e escrever, num curto espaço de tempo, através de cartilhas pré-fabricadas, impostas e decoradas, sem uma preocupação com a formação humana.

O conteúdo das palavras ensinadas pelo MOBRAL, diferente do método Paulo Freire (que utilizava a "palavra geradora" retirada do cotidiano dos aprendentes) era definido por tecnocratas (que as escolhiam a partir do estudo das necessidades humanas básicas).

A recessão econômica, iniciada nos anos 80, inviabilizou a continuidade do programa MOBRAL, que incluía projetos tais como o Programa de Alfabetização Funcional (cujo objetivo era alfabetizar através de técnicas de leitura, escrita e cálculo que os enquadrasse em seu meio social); o Programa de Educação Integrada (o objetivo era a continuidade dos estudos iniciados no Programa de Alfabetização Funcional); o Programa MOBRAL Cultural (visava uma educação permanente, que diminuísse a evasão e a reprovação); e o Programa de Profissionalização (iniciado para diversificar as atividades do MOBRAL).

A partir de 1985, a Fundação Movimento Brasileiro de Alfabetização - MOBRAL (que tinha recursos de um percentual da Loteria Esportiva e das deduções do Imposto de Renda) tornou-se muito onerosa e foi substituída pela Fundação Nacional para Educação de Jovens e Adultos - EDUCAR (1985 a 1990) - criada pelo Decreto número 91.980/1985. A EDUCAR estava dentro das competências do MEC e tinha como especialidade a "educação básica". Seu objetivo era "promover a execução de programas de alfabetização e de educação básica não formal, destinados aos que não tiveram acesso à escola ou dela foram excluídos prematuramente". Em 1990, a Fundação EDUCAR também foi extinta. Em seu lugar, com duração de apenas um ano, surgiu o Plano Nacional de Alfabetização e Cidadania - PNAC.

Em 1997, surgiu o Programa de Educação Solidária - PAS. Esse programa, inicialmente uma meta do então presidente Fernando Henrique Cardoso, possuía como objetivo a inserção de pessoas não alfabetizadas na Educação de Jovens e Adultos e a continuidade dos estudos. Era dividido em módulos, com seis meses de duração cada um, e os livros utilizados são cedidos pelo MEC. Vigeu até o segundo semestre de 2002, quando então passou a se chamar AlfaSol, uma Organização Não-Governamental (ONG), que continua atuando até os dias de hoje na alfabetização de jovens e adultos.

Em 2003, surge o Programa Brasil Alfabetizado, cujo foco é a Educação de Jovens e Adultos (EJA) população acima dos 15 anos, e visa não só a alfabetização, como também erradicar o analfabetismo e possibilitar a inclusão social de pessoas analfabetas. Conta com o apoio do governo, de empresas, de Institutos de Empreendedorismo Social (IES), de Organizações Não Governamentais (ONGs), de associações e de outras organizações da sociedade civil. É proposto em módulos de oito meses de duração e não oferece merenda para os alfabetizandos.

\subsection{CONSTRUINDO REFERÊNCIAS TEÓRICO-METODOLÓGICAS: 0 “MÉTODO PAULO FREIRE”.}

0 "método" Paulo Freire foi desenvolvido na década de 60, e consistia na alfabetização pela construção do conhecimento de forma conjunta pelo educador e pelo educando. Uma educação de dentro para fora, que levava à libertação do homem pelo conhecimento. Inicialmente, Freire praticou sua proposta políticopedagógica em Recife/PE, alfabetizando 300 trabalhadores em 45 dias, o que fez com que o então presidente do Brasil, João Goulart, o chamasse para organizar uma campanha nacional de alfabetização. 0 golpe de 64 impediu a realização deste intento.

No entanto, quando se fala em educação de jovens e adultos, é essencial falar em Paulo Freire e em seus estudos voltados aos que chamava de oprimidos, e cujos processos de ensino-aprendizagem eram conhecidos como "Sistema Paulo Freire", um pensamento pedagógico assumidamente político, embora o próprio Freire reconhecesse que há uma "crença ingênua, mais ou menos generalizada, no poder da educação institucionalizada como alavanca da transformação da realidade". Foi o mais célebre educador brasileiro, com atuação e reconhecimento internacionais. Para Freire, o objetivo maior da educação é conscientizar o aprendente alfabetizando. Segundo Carlos Alberto Torres, em seu Diálogo e Práxis Educativa:

Em última instância, parece-nos que a proposta pedagógica de Paulo Freire visa não tanto chegar a um "homem político" - no sentido de categoria políticoespiritual, como práxis cultural subjetivada e subjetivante da antropologia europeia -, mas pretende, basicamente, integrar o indivíduo ao povo. 0 educador acreditava em um método de educação construído com base no diálogo entre educador e educando. Via a construção da alfabetização através 
do levantamento de dados juntamente com a comunidade envolvida como um ato coletivo. (2014, p.25).

Dito isso, é possível relacionar o pensamento de Paulo Freire com a realidade dos estudantes da escola Fued Kalil, auxiliando-os a integrarem-se à comunidade na qual estão inseridos, buscando sua transformação pessoal e social bem como da sua realidade, descobrindo que "o importante mesmo não é ler histórias alienadas e alienantes, mas fazer história e por ela ser feitos".

Para Freire (2015, p. 231), "Não é possível atuar em favor da igualdade, do respeito aos direitos, à voz, à participação, à reinvenção do mundo, num regime que negue a liberdade de trabalhar, de comer, de falar, de criticar, de ler, de discordar, de ir e vir, a liberdade de ser". Segundo o autor estudado, "não há educação sem esperança". 0 objetivo de Paulo Freire era erradicar o analfabetismo, desenvolvendo uma educação libertadora e democrática a partir da realidade dos educandos.

\subsection{METAS E ESTRATÉGIAS: OS PLANOS NACIONAL, ESTADUAIS E MUNICIPAIS DE EDUCAÇÃO.}

A erradicação do analfabetismo e a universalização do atendimento escolar são diretrizes dos planos nacionais, estaduais e municipais de educação. Constam na Lei no 5.534, de 18/08/2015, que instituiu o Plano Municipal de Educação de Bagé e na Lei no 14.705, de 25 de junho de 2015, que instituiu o Pla no Estadual de Educação - PEE/RS; ambas elaboradas em cumprimento ao Plano Nacional de Educação PNE - que foi aprovado pela Lei Federal n. o 13.005, de 25 de junho de 2014, e tem vigência de dez anos a contar da publicação. Essas diretrizes estão formalizadas em metas e estratégias. A Meta 9 do Plano é "Elevar a taxa de alfabetização da população com 15 (quinze) anos ou mais para 98\% (noventa e oito por cento) até 2015 e, até o final da vigência deste PEE, universalizar a alfabetização e reduzir em 55\% (cinquenta e cinco por cento) a taxa de analfabetismo funcional". Esta meta desdobra-se nas estratégias 9.1; 9.5 e 9.15 do PEE, que se referem ao mapeamento sistemático da população analfabeta e à abordagem da redução do analfabetismo funcional por meio da EJA.

Na Lei Municipal no 5.534, de 18/08/2015, que institui o Plano Municipal de Educação de Bagé, a EJA é contemplada na Meta 9, cujo texto remete à meta 9 do PEE, e nas estratégias 9.1; 9.2 e 9.3 que visam, respectivamente, assegurar a oferta gratuita da educação de jovens e adultos a todos os que não tiveram acesso à educação básica na idade própria, verificar a demanda ativa por vaga na Educação de Jovens e Adultos, e implementar ações de alfabetização de jovens e adultos com garantia de continuidade da escolarização básica.

Desde 2017, em Bagé, RS, está sendo desenvolvido um projeto, pela Secretaria de Educação, sob a supervisão da Coordenadora da EJA, cuja meta é combater a evasão dos alunos matriculados no programa. 0 presente projeto de pesquisa está em consonância com os Planos Nacional, Estadual e Municipal de Educação, engajado na luta pela erradicação do analfabetismo. Pensamos que, na era da informação e da comunicação, não se pode admitir que uma parcela significativa da população permaneça sem acesso até mesmo aos códigos da leitura e da escrita.

Acredita-se que a divulgação das transformações ocasionadas pela possibilidade de alfabetização será um fator motivacional aos demais membros da comunidade local na busca do conhecimento, contribuindo para o alcance das metas dos Planos de Educação, aplicando a teoria de Paulo Freire e colaborando com o que ele almejava, ou seja, a erradicação do analfabetismo. Pretende-se dar voz e visibilidade a esta parcela quase esquecida da sociedade de Bagé, através da análise de um contexto no qual sujeitos pensantes dizem a sua palavra, para que mais pessoas, também em situação de vulnerabilidade e marginalização, queiram buscar o conhecimento.

\subsection{O ESPAÇO DOS SUJEITOS PENSANTES: ESCOLA ANTÔNIO FUED KALIL}

A Escola Municipal de Ensino Fundamental Antônio Fued Kalil, nome dado em homenagem ao empresário bajeense Antônio Fued Kalil, fundador da Loja Salim Kalil, filho de comerciantes libaneses, um altruísta que muito auxiliou em obras assistenciais da cidade, inaugurada em 14 de março de 1985, é uma das nove escolas de Bagé que ministram a EJA. Está localizada na comunidade do Passo das Pedras, um dos sete bairros da região sul do município de Bagé. Distante do centro da cidade, o Passo das Pedras é uma comunidade pobre, com baixos índices de alfabetização e altas taxas de desemprego e dependência das políticas assistenciais. 
A escola atende, no período diurno, a educação infantil e o ensino fundamental e, a partir do ano 2008, no período noturno, a Educação de Jovens e Adultos - EJA - Anos Iniciais e Anos Finais. Neste programa, em 2015, havia 56 estudantes matriculados no primeiro semestre letivo e 57 no segundo semestre.

Em 2016 foram 61 estudantes no primeiro semestre e 45 no segundo (destes, 21 eram homens e 24 eram mulheres, com faixa etária entre 15 e 72 anos). Em 2017, 74 estudantes se matricularam no primeiro semestre (ou seja, um aumento de $64,44 \%$ sobre as matrículas do semestre anterior) e 62 no segundo.

\subsection{A PEDAGOGIA DA AUTONOMIA, DE PAULO FREIRE: RELAÇÃO EDUCADORES-EDUCANDOS NA EJA.}

Não há docência sem discência, as duas se explicam e seus sujeitos, apesar das diferenças que os conotam, não se reduzem à condição de objeto um do outro. Quem ensina aprende ao ensinar e quem aprende ensina ao aprender. (FREIRE, 2015, p.25)

As palavras da obra analisada, com as quais iniciamos este tópico de estudo, clarificam exatamente a importância de considerar equivalentes em significado os saberes de educadores e educandos. Considerar as histórias de vida de alguns educandos da escola Fued Kalil nos leva o mais próximo possível da realidade dos sujeitos pensantes com os quais passamos a dialogar, incluindo-os no ambiente escolar e utilizando o conhecimento de seus saberes e de suas experiências de vida como um valioso instrumento pedagógico na busca de compreensão das especificidades de vida de cada um deles.

Contemplar as trajetórias de vida dos envolvidos na alfabetização permite trazer a teoria para a realidade, valorizando os saberes de cada um, promovendo trocas de experiências e auxiliando a que possam "dizer sua palavra" (FIORI, in Prefácio Pedagogia do Oprimido, 2015), posicionando-se sobre o que acreditam e refletindo formas de promover a própria melhoria de vida. A chamada "educação bancária" é, assim, substituída por uma forma de educação que integra e constrói conjuntamente o saber pelos educadores e pelos educandos.

Há uma pequena história que exemplifica bem o que a educação bancária faz. É mais ou menos assim: em seu primeiro dia de aula, a menina estava empolgada. Quando a professora disse Vamos fazer um desenho, ela logo pensou vou desenhar uma casa, um lago e lindas montanhas. Já estava a rabiscar quando a professora falou novamente: Calma! Ainda não falei o que vamos desenhar! Vamos desenhar uma flor. E foi logo mostrando como era a flor que deveriam desenhar. A menina pensou: meu desenho ficaria mais bonito; mas, tudo bem, vamos desenhar aquela flor. E copiou a flor que estava no quadro. Então a professora disse: Agora vamos pintar. A menina pegou logo sua cor favorita, o azul, e já ia pintar a primeira pétala quando a professora voltou a falar: Calma! Ainda não disse de que cor vamos pintar. Primeiro vamos pintar as pétalas de vermelho. A menina pensou: azul seria mais bonito; mas, vamos pintar de vermelho. E, assim, passaram-se os meses, até que, um dia, a professora da classe adoeceu e veio outra para substituir. Então, a nova professora disse: Vamos fazer um desenho... e não falou mais nada. A menina ficou quietinha, esperando, até que a professora falou novamente: E então? 0 que está esperando? Você não vai desenhar? E a garotinha respondeu: Mas, você ainda não disse o que vamos desenhar!

A história ilustra o tipo de educação bancária combatida por Paulo Freire. Uma educação que tolhe a criatividade, que coloca os educandos "dentro de uma caixa" apertada, para que eles somente façam os movimentos que sejam ordenados. Para o educador Paulo Freire, o aprendizado é construído de forma conjunta, a partir do universo de conhecimento dos educandos, valorizando seus saberes e sua realidade de forma a deixar claro que "ensinar não é transferir conhecimento, mas criar as possibilidades para a sua produção ou a sua construção" (FREIRE, 2015, p.24). 0 educador deve propor ao educando um trabalho que propicie o despertar de suas capacidades, o desenvolvimento de seu raciocínio, sua criatividade e ousadia, e um melhor desempenho na realização das atividades, buscando gerar soluções em vez de importar modelos prontos que quase nunca cabem exatamente na realidade envolvida.

A educanda Ana ${ }^{8}$, de 64 anos, nos diz "voltei a estudar para conviver com dignidade e ser respeitada em minhas escolhas". Este depoimento demonstra que os estudantes entendem a alfabetização como fator de resgate da dignidade e como facilitador de afirmarem suas escolhas, de terem condições de pegarem na mão a própria história.

${ }^{8}$ Utilizou-se, neste trabalho, nomes fictícios para preservar a identidade dos estudantes. 
Esse discurso é corroborado pela obra Pedagogia da Autonomia quando afirma que "nas condições de verdadeira aprendizagem os educandos vão se transformando em reais sujeitos da construção e da reconstrução do saber ensinado, ao lado do educador, igualmente sujeito do processo" (FREIRE, 2015, p.28). Quanto aos educadores, o autor nos diz:

(...) é fundamental que, na prática da formação docente, o aprendiz de educador assuma que o indispensável pensar certo não é presente dos deuses nem se acha nos guias de professores que iluminados intelectuais escrevem desde o centro do poder, mas, pelo contrário, o pensar certo que supera o ingênuo tem que ser produzido pelo próprio aprendiz em comunhão com o professor formador. (FREIRE, 2015, p.39).

Assim, na busca do resgate da dignidade, a escolarização aparece como fator determinante, mas o saber precisa ser construído conjuntamente, o educador creditando mesmo a importância que a trajetória de vida do educando representa nesta busca, valorizando seu contexto e seus saberes.

As escolas, em sua grande maioria, não estão preparadas sequer fisicamente para receber estudantes adultos. Os espaços utilizados pelos discentes da EJA no período noturno são, geralmente, os mesmos que os do ensino fundamental utilizam no período diurno. As classes são pequenas, feitas para crianças, a decoração das salas é a utilizada pelos professores do ensino fundamental regular e, inclusive, muitos planos de aula são os utilizados para ensinar as crianças, resultando em um ensino infantilizado para adultos, o que não é o ideal e, muitas vezes, é fator de evasão nas classes de jovens e adultos.

A presença maciça de estudantes com idade próxima dos quinze anos, desinteressados, com objetivos do tipo: "voltei a estudar para minha mãe parar de incomodar", como diz Marcos, de 15 anos, em seu depoimento, é outro dos inúmeros fatores que podem levar ao desestímulo de pessoas com mais idade, realmente interessadas nos processos educativos. Este, no entanto, deve ser fator de busca constante de formação adequada por parte dos educadores, que devem tentar tornar a escola mais atraente do que aquela que levou esses jovens a evadirem, outrora. Instigado pela professora a procurar um motivo que não envolvesse ninguém além dele mesmo para o retorno aos estudos, o estudante reformulou sua resposta dizendo que havia voltado a estudar por querer ser militar. Segundo Paulo Freire, não se trata de transferir conhecimentos apenas, mas de saber que ensinar é criar as possibilidades para que os próprios educandos façam a construção dos seus saberes, de forma que "sua presença no mundo seja a de quem nele se insere e não a de quem a ele se adapta. Que seja a posição de quem luta para não ser apenas objeto, mas sujeito também da história" (FREIRE, 2015, p.53).

Ainda sobre a importância da construção dos saberes, passamos a analisar o depoimento da educanda Rosinha, de 60 anos:

"Resolvi estudar porque eu sempre via as pessoas lendo revistas, escrevendo cartas ou recados e eu achava muito bonito. Então eu pensei que poderia fazer igual, foi que pensei vou estudar. Para mim saber ler é muito importante, pois posso mexer no computador, no celular e também escrever cartas e recados aos meus amigos. Foi quando apareceu a professora Maria fazendo aquela interpretação de texto, nesse momento compreendi que eu também podia interpretar texto como ela. Portanto, estudar é muito importante e muito útil para mim."

Levada pelo entusiasmo da educadora na interpretação dos textos em sala de aula, a educanda sentiu que também ela poderia interpretar o mundo a partir da alfabetização, sendo sujeito de sua própria história de vida. Reconheceu-se como ser inconcluso e inseriu-se em um processo de busca. Esse processo faz parte, de acordo com Freire, da educação problematizadora, em oposição à educação bancária. Ao reconhecerem-se "inacabados, inconclusos, em e com uma realidade" (FREIRE, 2015, p.42, grifo do autor) inserem-se em um processo de busca, no ambiente escolar, por mais saber, por mais autonomia.

Assim como no relato anterior, a importância da alfabetização como fator de autonomia é comprovada no depoimento de Camila, de 66 anos, que nos diz que decidiu estudar para aprender a ler e escrever por que acha "muito triste não saber ler uma receita ou uma conta de luz". E no depoimento de Marta, de 70 anos, que não teve oportunidade de estudar quando criança por não ter escola no lugar onde morava, mas que considera "muito bom saber ver, no mercado, se algo está vencendo, analisar os papéis do banco, determinar-se por conta própria, sem depender dos outros para tudo, e viajar sozinha, o que antes não era possível”. Segundo Freire, "mulheres e homens se tornaram educáveis na medida em que se reconheceram 
inacabados" (FREIRE, 2015, p.57). Essas mulheres tiveram a humildade de reconhecerem-se inacabadas, e, assim, buscaram a alfabetização.

Os educadores têm papel preponderante no caminho de retorno ou de busca pela alfabetização vista por sujeitos adultos como fator de autonomia. "Por isso é que, na formação permanente de professores, o momento fundamental é o da reflexão crítica sobre a prática. É pensando criticamente a prática de hoje ou de ontem que se pode melhorar a próxima prática. (FREIRE, 2015, p.40).

Desenvolver uma relação e afetuosidade com os educadores é importante para os educandos da EJA. Os adultos aprendizes buscam, na relação com seus educadores, uma sintonia, uma afetividade diferente da busca afetiva insegura e carente dos pequenos. A relação docente - discente, na EJA, precisa ser pautada na afetividade, no respeito aos saberes de ambos. Como educador de adultos devo "saber que devo respeito à autonomia, à dignidade e à identidade do educando e, na prática, procurar a coerência com esse saber" (FREIRE, 2015, p.61).

A disponibilidade também é fator preponderante na relação do educador com seus educandos. Segundo Freire, "Estar disponível é estar sensível aos chamamentos que nos chegam, aos sinais mais diversos que nos apelam" (FREIRE, 2015, p.131). A aluna Selma, de 26 anos, nos diz de sua necessidade de contar com a disponibilidade de alguém que ensine, pois relata que voltou a estudar para "nunca mais passar vergonha ou ser debochada" pelas pessoas que sabem mais do que ela. Quer ensinar aos seus filhos para que eles não passem pelo que ela já teve que passar.

Assim como a disponibilidade, também é necessária a alegria que envolve a prática educativa na EJA, segundo Paulo Freire:

“Há uma relação entre a alegria necessária à atividade educativa e a esperança. A esperança de que professores e alunos juntos podemos aprender, ensinar, inquietar-nos, produzir e juntos igualmente resistir aos obstáculos a nossa alegria" (FREIRE, 2015, p.70).

Imaginemos um adulto que trabalhou o dia todo, vir à noite para uma escola triste, que falte com a alegria, com professores desmotivados e carrancudos. Certamente esse adulto não sentiria a necessária motivação para enfrentar um terceiro turno nessas condições. 0 depoimento do estudante Guilherme, de 15 anos, em certo momento nos revela isso, ao dizer que acredita que tudo na vida tenha um porquê e que deveríamos nos questionar do porquê estudar ou "por que aguentar um professor falando o que não nos convém, até o ponto de dar sono". Freire nos diz que "uma das tarefas fundamentais do educador progressista é, sensível à leitura e à releitura do grupo, provocá-lo, bem como estimular a generalização da nova forma de compreensão do contexto" (FREIRE, 2015, p.80).

Segundo Freire, "o essencial nas relações entre educadores e educandos, entre autoridade e liberdade, entre pais, mães, filhos e filhas é a reinvenção do ser humano no aprendizado de sua autonomia" (FREIRE, 2015, p.92). Esse o fim maior da escola enquanto espaço educativo para que o ser humano possa se reinventar enquanto ser em construção, superar sua ignorância e se apropriar de sua autonomia, de forma que possa intervir no mundo que o circunda. No entanto, Freire segue e reconhece que "as condições materiais em que e sob que vivem os educandos lhes condicionam a compreensão do próprio mundo, sua capacidade de aprender, de responder aos desafios" (idem). Sofia, de 50 anos, acredita que "nunca é tarde para aprender e que não devemos desistir nunca de aprender e de tentar arrumar um serviço melhor". Para Sofia, aprender significa "uma chance de conseguir algo melhor" e, como seres inconclusos que somos, nunca é tarde para aprender.

Ainda que por vezes o educador veja em seus educandos sonhos longínquos da realidade em que se inserem, sonhar também é um direito inalienável do ser humano. Os sonhos movem as pessoas em direção aos seus objetivos. Os sonhos colocam as pessoas em marcha. Freire nos diz, na obra que estamos estudando frente à realidade dos educandos da Escola Antônio Fued Kalil que "Se não posso, de um lado, estimular os sonhos impossíveis, não devo, de outro, negar a quem sonha o direito de sonhar. Lido com gente e não com coisas" (FREIRE, 2015, p.141). E quem poderá dizer que um ou outro sonho seja impossível? Laura, de 25 anos, mãe de dois filhos e estudante das séries iniciais, nos diz que sempre foi muito sonhadora e que, dos seus inúmeros sonhos, "o mais antigo sempre foi ser psicóloga". Ela sabe que poderá ser difícil realizar seus sonhos, mas quer que seus filhos tenham orgulho dela ao menos estar tentando chegar lá.

Seguindo no estudo da obra "Pedagogia da Autonomia", de Paulo Freire, citamos mais uma fala do educador: 
se nunca idealizei a prática educativa, se em tempo algum a vi como algo que, pelo menos, se parecesse com um quefazer de anjos, jamais foi fraca em mim a certeza de que vale a pena lutar contra os descaminhos que nos obstaculizam de Ser Mais. (FREIRE, 2015, p.142)

Penso ser esse o dever primeiro de um educador: trazer em si a certeza de que vale a pena lutar contra os descaminhos que nos obstaculizam de "Ser mais".

\subsection{APRESENTANDO (IN)CONCLUSÕES: E PROSSEGUINDO EM DIÁLOGO.}

Aqui chegamos ao ponto em que talvez devêssemos ter partido. 0 do inacabamento do ser humano. Na verdade, o inacabamento do ser ou sua inconclusão é próprio da experiência vital. Onde há vida, há inacabamento. Mas só entre mulheres e homens o inacabamento se tornou consciente. (FREIRE, 2015, p.50).

Para prosseguirmos em diálogo neste fascinante assunto, apresentamos nossas (in)conclusões, reconhecendo o fato do inacabamento que nos toma ao tratarmos de um contexto vivo de saberes. De acordo com a obra estudada, a prática de um diálogo político-pedagógico calcado em virtudes éticas pode estabelecer condições de modificar as formas de ver o mundo. Pensamos que isso é real e pode ser comprovado pelo depoimento, por exemplo, da alfabetizanda-Rosinha (60 anos), que "sempre via as pessoas lendo revistas, escrevendo cartas ou recados e achava bonito", até que, inserida no ambiente escolar, uma de suas professoras trabalhou interpretação de textos e ela, ao ver a professora "interpretar", acreditou que também poderia interpretá-los. A estudante poderia ter referido que "também poderia ler", mas, em vez disso, ela teve a percepção de referir que a professora "interpretava" os textos e, assim, incentivada por esse diálogo, e acreditou que ela também poderia "interpretar texto".

Buscamos saber qual a forma de interpretação feita e descobrimos que a professora costumava trabalhar os textos em aula (crônicas, poesias, contos), dentro de uma prática dialógica interpretativa, "conversando" com os personagens, imitando suas falas, suas entonações e seus gestos e incentivando os estudantes a fazerem o mesmo, ou seja, fazerem leituras conscientes, visualizando, sentindo e vivendo os personagens lidos.

A aplicabilidade da Pedagogia da Autonomia de Paulo Freire, quanto às modificações provocadas nos discentes em suas formas de inter-relacionar-se e/ou articular-se com o mundo, também restou comprovada. Dentre outros depoimentos, vejamos o de Ana (64 anos), que nos diz que "voltou a estudar para conviver com dignidade e ser respeitada em suas escolhas". Percebemos que, apesar das dificuldades encontradas pelos adultos que decidem estudar, como enfrentar um terceiro turno, ainda que tenham de levar seus filhos junto para a escola, ou sair direto do trabalho sem tempo para merendar em casa (este semestre a escola não estava fornecendo refeição noturna), ainda assim, entendem a importância de estarem na escola e mantêm-se frequentando as aulas regularmente.

Pudemos verificar alguns dos motivos que levam as pessoas a voltarem a estudar ou a procurarem se alfabetizar, ainda que já estejam com mais idade. Esses motivos vão desde coisas do dia a dia, como a necessidade de ler uma bula de remédio, saber qual ônibus as levará onde necessitam, ver o preço das coisas no supermercado e suas datas de vencimento, até maiores transformações em seus cotidianos, como sentar e ler, ou melhor, "interpretar" leituras. O que comprova, ainda, que as relações entre educadores e educandos influencia sim, diretamente, a forma de aprender de jovens e adultos modificando sua forma de ver o mundo e relacionar-se com ele.

Quanto aos discentes mais jovens, foi possível perceber que são necessárias algumas modificações nos processos de ensino-aprendizagem para que se possa evitar o grande problema da evasão e da recidiva. Caso as escolas continuem reproduzindo, na EJA, o mesmo modelo de ensino das escolas de ensino regular, aqueles que já fracassaram lá, aqui também não terão sucesso e suas motivações para estarem em sala de aula continuarão sendo "para a minha mãe parar de incomodar", como nos disse o estudante Marcos, de 15 anos. Este mesmo estudante, no entanto, comprova a teoria de que, com amorosidade e diálogo, podemos modificar atitudes e ajudar o educando a encontrar uma motivação outra para estar na escola, qual seja, a esperança de um futuro na carreira militar. 


\subsection{SEGUIMOS: DISPONIBILIDADE PARA O VIR A SER.}

A partir da análise da aplicabilidade da Pedagogia da Autonomia de Paulo Freire junto aos discentes da EJA, foi possível destacar a importância das relações afetivas no processo de alfabetização de adultos.

Os depoimentos dos estudantes demonstram que as pessoas voltam a estudar buscando uma melhor compreensão dos códigos que decodificam o mundo. Buscam, ainda, autonomia para suas tarefas cotidianas e sentirem-se sujeitos-integrantes da sociedade.

Percebemos que as pessoas sentem vergonha de seus pares por não saberem os códigos da leitura e da escrita e que, por esse motivo, tornam-se alvo de chacotas. É possível perceber claramente as transformações ocorridas no cotidiano dos estudantes na alfabetização. Os relatos mostram que eles passam a ser sujeitos da própria história, já não dependem de outros para realizarem tarefas simples do dia-a-dia, como ler uma revista, escolher o ônibus certo, ver o preço das mercadorias, saber a validade delas, ler uma bula de remédio, uma receita médica e auxiliar os filhos em seus deveres escolares, dentre inúmeras outras atividades simples que antes eram de difícil realização; sentem-se com autonomia pessoal e cidadã.

Isso comprova que o objetivo geral deste estudo foi alcançado, ou seja, foi possível analisar como sendo aplicável a Pedagogia da Autonomia, de Paulo Freire, junto aos estudantes da EJA da Escola Municipal de Ensino Fundamental Antônio Fued Kalil. Também os objetivos específicos foram atingidos, com o reconhecimento da aplicabilidade da Pedagogia da Autonomia de Freire junto aos estudantes da EJA, com o destaque dado à importância das relações afetivas no processo de alfabetização de adultos e com a comprovação das transformações ocorridas no cotidiano dos aprendentes na alfabetização (maior autonomia em suas tarefas, autodeterminação).

Pensamos que a hipótese formulada para este trabalho é validada, ou seja, é possível afirmar que as relações entre educadores e educandos influencia diretamente a forma de aprender dos jovens e adultos modificando sua forma de ver o mundo e relacionar-se com ele.

Os educandos se espelham em seus educadores, como pode ser claramente percebido no depoimento de uma das aprendentes que relata que, ao ver sua professora interpretando textos, percebeu que também ela poderia fazer isso.

Foi possível descobrir algumas das causas que levam as pessoas a voltarem a estudar: adquirir mais conhecimento; passar a conviver com dignidade; ser respeitadas; ter uma profissão; realizar sonhos; servir de exemplo para os filhos; analisar documentos por conta própria, etc. Também foi possível perceber algumas modificações em seus cotidianos após a alfabetização: viajar sozinhos; saber qual ônibus leva onde se quer ir; não comprar produtos vencidos; ajudar os filhos nas tarefas, etc. E, assim, partindo de nossas (in)conclusões e conscientes de que:

Estar disponível é estar sensível aos chamamentos que nos chegam, aos sinais mais diversos que nos apelam, ao canto do pássaro, à chuva que cai ou que se anuncia na nuvem escura, ao riso manso da inocência, à cara carrancuda da desaprovação, aos braços que se abrem para acolher ou ao corpo que se fecha na recusa. (FREIRE, 2015, p.131).

Continuaremos disponíveis ao diálogo com os sujeitos pensantes com os quais convivemos e com os quais construímos um espaço vivo de conquista de saberes.

\section{REFERÊNCIAS}

[1] Brasil. Constituição da República Federativa do Brasil de 1988. Disponível em: http://www.planalto.gov.br/ccivil_03/constituicao/constituicao.htm. Acesso em: 09 mai. 2017.

[2] Brasil. Lei $\mathrm{n}^{\circ} 9.394$ de 20 de dezembro de 1996. Estabelece as diretrizes e bases da educação nacional. Disponível em: http://www.planalto.gov.br/ccivil_03/leis/_L9394.htm. Acesso em: 09 mai. 2017.

[3] Brasil. Parecer no 11 de 10 de maio de 2000. Conselho Nacional de Educação - CNE. Diretrizes Curriculares Nacionais para a Educação de Jovens e Adultos. Disponível em: http://portal.mec.gov.br/cne/arquivos/pdf/pceb011_00.pdf. Acesso em: 09 mai. 2017.

[4] Brasil. Resolução $n^{\circ} 1$ de 5 de julho de 2000. Estabelece as Diretrizes Curriculares Nacionais para a Educação de Jovens e Adultos. Disponível em: http://portal.mec.gov.br/cne/arquivos/pdf/CEB012000.pdf. Acesso em: 09 mai. 2017. 
[5] Brasil. Lei n 10.172 de 9 de janeiro de 2001. Aprova o Plano Nacional de Educação e dá outras providências. Disponível em: http://www.planalto.gov.br/ccivil_03/leis/leis_2001/110172.htm. Acesso em: 09 mai. 2017.

[6] Brasil. Decreto no 6.093 de 24 de abril de 2007. Dispõe sobre a reorganização do Programa Brasil Alfabetizado, visando à universalização da alfabetização de jovens e adultos de quinze anos ou mais, e dá outras providências. Disponível em: http://www.planalto.gov.br/ccivil_03/_ato2007-2010/2007/decreto/d6093.htm. Acesso em: 09 mai. 2017.

[7] Brasil. Lei ${ }^{\circ} 11.741$ de 16 de julho de 2008. Altera dispositivos da Lei no 9.394, de 20 de dezembro de 1996. Disponível em: http://www.planalto.gov.br/ ccivil_03/_ato2007-2010/2008/lei/l11741.htm. Acesso em: 09 mai. 2017.

[8] Brasil. Lei no. 12.796 de 04 de abril de 2013. Altera a Lei no. 9.394 de 20 de dezembro de 1996. Disponível em: http://www.planalto.gov.br/ccivil_03/_ato2011-2014/2013/lei/l12796.htm. Acesso em: 09 mai. 2017.

[9] Brasil. Lei no 13.005 de 25 de junho de 2014. Aprova o Plano Nacional de Educação - PNE - e dá outras providências. Disponível em: http://www.planalto. gov.br/ccivil_03/_ato2011-2014/2014/lei/l13005.htm. Acesso em: 09 mai. 2017.

[10] Brasil. LEI № 14.705, de 25 de junho de 2015. Institui o Plano Estadual de Educação - PEE -, em cumprimento ao Plano Nacional de Educação - PNE -, aprovado pela Lei Federal n.․ 13.005, de 25 de junho de 2014; e LEI MUNICIPAL № 5.534, de 18/08/2015. Institui o Plano Municipal de Educação de Bagé. Disponíveis em: http://pne.mec.gov.br/planos-de-educacao/situacao-dos-planos-de-educacao. Acesso em 10/05/2017.

[11] Freire, Paulo. A alfabetização de adultos: é ela um fazer neutro? Disponível em: http://www.acervo.paulofreire.org:8080/jspui/bitstream/7891/2567/3/FPF_OPF_03_001.pdf._ Acesso em $16 / 05 / 2017$.

[12] Freire. Cartas a Cristina: Reflexões sobre minha vida e minha práxis. 2ª ed. São Paulo, SP. Paz e Terra, 2015.

[13] Freire. Pedagogia da Autonomia: saberes necessário à prática educativa. 52ª ed. São Paulo, SP. Paz e Terra, 2015.

[14] Freire. Pedagogia do Oprimido. 62 2 ed. Rio de Janeiro, RJ: Paz e Terra, 2016

[15] Leal, Titiva Cardona. Contribuições de Paulo Freire à educação brasileira. $2^{\underline{a}}$ ed. Pelotas, RS. Editora da UFPel. 2007.

[16] Minayo, M. C. S. (org.). Pesquisa social: teoria, método e criatividade. Petrópolis, RJ. Vozes. 2001.

[17] Scheibel, Maria Fani; Lehenbauer, Silvana. Saberes e singularidades na educação e jovens e adultos. $2^{\underline{a}}$ ed., Porto Alegre, RS. Editora Mediação. 2010.

[18] Torres, Carlos Alberto. Diálogo e Práxis Educativa: Uma leitura crítica de Paulo Freire. São Paulo, SP. Edições Loyola. 2014. 


\section{Capítulo 7}

Relato de experiência a inspiração freireana na EJA: Articulando o ético e o estético

\section{Luciane Maria Ribeiro da Cruz Santos}

Resumo: 0 artigo apresenta uma experiência didática com uma turma de Educação de Jovens e Adultos em que as dimensões ética e estética se articulam. A ação didática baseou-se na proposição de contextos de discussão sobre o cotidiano dos estudantes e na oferta de textos literários para leitura e fruição. As diretrizes da Educação de Jovens e Adultos foram princípios orientadores aos quais se somou a concepção freireana para o desenvolvimento de um conceito pedagógico em que o estudante participe mais ativamente das discussões das aulas e por meio delas ocorram reflexões que apoiem novas formas de compreensão do mundo, dos problemas sociais, de si mesmo sem se perder o encanto com as possibilidades estéticas oferecidas pela literatura. Os resultados deste trabalho revelam como a poesia pode ser meio de apreciação e reflexão sobre a própria vida. Estudantes adultos sem experiências anteriores de escolarização e contatos com a literatura interagem ética e esteticamente com obras literárias.

Palavras chave: Educação de Jovens e Adultos, Educação popular, Educação permanente, Contribuições freireanas. 


\section{INTRODUÇÃO}

Educadores têm em Paulo Freire uma fonte rica de inspirações. As ideias freireanas oferecem ricos conteúdos para a reflexão sobre a sociedade e o ato educativo concebido em seu caráter humanizador em que estão implicadas as dimensões éticas e estéticas.

O significado latino do termo Experientia "conhecimento obtido por repetidas vezes", de Experiri, "testar", formado por Ex "fora" e Peritus "conhecimento" se revela na situação pedagógica descrita. Tanto na perspectiva de quem relata quanto na daqueles de quem se fala observa-se a repetição, para além da concepção mecânica das práticas didáticas, como o aprimoramento e a busca do sentido e da apropriação dos conteúdos presentes nas aulas.

0 presente relato pretende uma reflexão, à luz das contribuições freireanas, sobre a experiência desenvolvida em uma turma noturna da modalidade de EJA de uma escola pública municipal de Itabira, em 2009. No mês de junho, uma ação da Prefeitura levou aos moradores da região de Ribeirão São José, zona rural do município, a possibilidade de serem transportados até a escola, situada na zona urbana.

Essa ação resultou na matrícula de 20 adultos entre 20 e 65 anos no primeiro período do curso, a iniciarse em julho daquele ano. A situação seria comum ao fazer da escola, não fosse o questionamento apresentado a um dos professores, por um dos alunos, quase um mês após o início das aulas: "estamos gostando muito da escola, mas quando vão nos ensinar a ler?"

A investigação da coordenadora pedagógica revelou que naquele grupo de alunos não havia um único aluno alfabético, apenas alunos que escreviam o próprio nome ou o copiavam de um outro texto, sempre trazido consigo. É fato comum à realidade brasileira, a existência de alunos analfabetos e a dificuldade, da instituição escolar de séries finais, de atuar considerando a necessidade dos próprios alunos e não as especificidades de sua própria pauta educativa.

No caso em tela, os alunos queriam ler. A escola queria ensinar "conteúdos escolares a alunos alfabetizados". Em outros dizeres, a escola noturna embora de jovens e adultos não era para aqueles jovens e adultos que nela tinham-se matriculado, desconhecedores das dificuldades da escola de abrir-se realmente a todos, superando seus formalismos e sua rigidez.

\section{DE ONDE PARTIMOS}

A educação de jovens e adultos é uma modalidade da educação básica, nas etapas do ensino fundamental e médio com especificidades próprias, estabelecidas pela LDB 9.394 de 1996 e pelo Parecer 11 de 2000 do CNE/CEB. Cury, na relatoria das diretrizes da EJA, defende a educação de jovens e adultos como reparação da dívida social com aqueles brasileiros e brasileiras que não tiveram acesso ao domínio da escrita e leitura fato que "é particularmente danoso para a conquista de cidadania plena". (BRASIL, 2000, p. 6) Estabelece três funções primordiais para o segmento de jovens e adultos; reparadora, equalizadora e qualificadora.

Sem confundir a função reparadora com a de suprimento e, em acordo com a Declaração de Hamburgo 1997, a EJA orientada por projeto pedagógico próprio pode ser uma nova partida em que os princípios da igualdade e da liberdade associados no fazer da escola prestem seu papel na redução das desigualdades para os excluídos do acesso aos bens advindos do domínio da leitura e da escrita. A função equalizadora é a possibilidade de retomada do desenvolvimento de habilidades para os que tiveram, por alguma razão, interrompidos os acessos aos bens culturais possíveis pela escolarização. Pelo caráter permanente da educação, a EJA pode propiciar atualização de conhecimentos, estimular diferentes leituras, desenvolver potenciais técnicos ou artísticos transcendendo os formalismos da escolarização e estendendo as ações educativas a públicos de qualquer idade.

Buscamos em Paulo Freire orientações para a ação pedagógica para aqueles cidadãos, conterrâneos de um dos maiores poetas da literatura mundial, cujas possibilidades de construir os sentidos advindos do ato de ler um texto escrito ficaram oclusas, por tempos. As ideias freireanas foram um conjunto de inspirações para ações que pretendiam ser transformadoras, concretizáveis para aquelas pessoas, cujo lugar na escola não estaria garantido pelas condições comuns do fazer pedagógico.

Tanto por oferecer a autonomia que possibilita às pessoas expressar-se e acessar o conhecimento de textos escritos, quanto pela esperança em se dotar das ferramentas de expressão da sociedade escrita propor uma ação para aqueles alunos era atuar na dimensão social e em uma perspectiva crítica.

No contexto aqui relatado, precisava-se dar concretude a um projeto de manter os alunos na escola. Como 
afirma Freire

(...) sem sequer poder negar a desesperança como algo concreto e sem desconhecer as razões históricas, econômicas e sociais que a explicam, não entendo a existência humana e a necessária luta para fazê-la melhor, sem esperança e sem sonho. A esperança é necessidade ontológica e a desesperança, a esperança que, perdendo o endereço, se torna distorção da necessidade ontológica. (Freire, 1997, p.5)

A esperança foi a motivação da coordenação para impedir o abandono iminente dos alunos que, matriculados, não faziam parte de algo que a escola poderia lhes oferecer, o mundo letrado. Foi a necessidade ontológica de sonhar e construir uma realidade em que os alunos fossem atendidos nas suas peculiaridades que levou à elaboração de um projeto de alfabetização de adultos, medida de intervenção pedagógica. A escola não tinha classes de alfabetização e não existiam condições práticas de transferência desses alunos para outra unidade escolar de séries iniciais que os pudesse atender, especificamente.

A educação permanente sustentada nas diretrizes da EJA (Brasil, 2000) e proposta por Freire (1993) fundamenta-se em uma concepção aberta de homem, "ser programado para aprender", que "jamais para de educar-se" (p.21) vocacionado para a humanização, aberto para e reinventado com os homens e as mulheres enquanto educa e se educa. Compreendemos, concordando com Freire, que a restrição das gentes à educação é restrição de cidadania, é uma forma de violência do Estado e da sociedade contra o cidadão. A escola e os professores devem se recusar a tomar papel ativo ou passivo nessa violência. A escola pública e democrática não pode prescindir da presença participante das pessoas das classes populares ainda que à ela, à escola, busquem adultas, com quaisquer dificuldades.

Pessoas que buscam a escola fora da faixa etária escolar, para um ensino noturno, após a lida de um dia inteiro na roça, no trato de suas criações, na carvoeira, o fazem para atender ao imperativo interior da necessidade de aprender, de educar-se. A escola deve acolhê-los movida pela necessidade imperativa de instruí-los e educá-los. 0 pensador do (Ser/Tornar-se) humano que é Paulo Freire (Streck, 2011) mobiliza educadores que se entendem capazes de oferecer resistência aos processos de opressão social apenas se se humanizam na relação com seus alunos.

\section{ATENDER AO OBJETIVO: NÃO PERDER A OPORTUNIDADE}

O projeto de intervenção pedagógica constituiu-se de formar uma turma com os alunos do Ribeirão São José, atendida pela coordenadora por duas horas e trinta minutos do tempo escolar, em atividades de alfabetização e letramento, após as quais os alunos retornavam às turmas de origem para outros contextos de interação e socialização. Era nossa preocupação possibilitar aos alunos tanto o contato com as discussões e o conteúdo do segmento da escola em que achavam tão importante estarem matriculados, quanto oferecer-lhes uma condição pedagógica efetivamente materializadora do direito que lhes fora negado na infância e juventude.

Direito de ler e ser lido, "de poder contar suas estórias, escrever uma carta para um parente ou um bilhete no serviço, de não ter medo de ser enganado no banco, ou de tomar o ônibus errado, de escolher as marcas de massa de tomates no supermercado pelo nome". Essas expressões ecoam da fala daqueles alunos, homens e mulheres que não liam textos escritos enquanto liam o mundo e as suas realidades com inegável profundidade.

O projeto desenvolvido para a turma compreendia como tarefa educativa não perder a oportunidade de ter a participação daqueles alunos no cotidiano da escola.

\section{METODOLOGIA: PENSAR, CONVERSAR, ESCREVER - ATOS DE UMA LEITURA}

Ao compreender de forma crítica e responsiva a EJA, assume-se um papel na Educação Popular. Conteúdos e procedimentos de ensino devem servir à superar do senso comum pela análise da realidade, reflexão crítica e conscientização sobre o capturável pela curiosidade arguta de educadores e educandos.

Organizamos o projeto de trabalho a partir de conteúdos abertos, trazidos para a discussão pelos próprios alunos em uma roda de conversa que iniciava todas as aulas. A partir dos conteúdos da roda de conversa, as situações vivenciadas pelos alunos eram analisadas, discutidas e ressignificadas. Selecionavam-se palavras, termos para o ensino da escrita e eram construídos textos para a leitura. 
A roda de conversa inspirava-se na experiência descrita no texto Educação e Conscientização (Freire, 1999) para analisar os sentidos das práticas sociais, as dificuldades dos cotidianos, as possibilidades de solução construídas pelas pessoas nas comunidades dos alunos.

Conteúdos como o Bolsa Família, o Fome Zero, a aposentadoria rural, as questões do sistema financeiro dificuldades de acesso à crédito, juros altos, cobrança de tarifas - o alcoolismo e a violência doméstica eram discutidos, analisados e dessas discussões eram retiradas as palavras a serem escritas, lidas, comparadas às anteriormente estudadas e, principalmente, aos nomes dos alunos.

As palavras geradoras pertenciam ao conteúdo crítico trazido pelos alunos e vivenciado por eles nas questões da vida cotidiana. Fugimos assim da memorização visual e mecânica de sentenças, de palavras, de sílabas, desgarradas de um universo existencial - coisas mortas ou semi mortas - mas numa atitude de criação e recriação (Freire, 2000, p. 119) e construíamos uma ação dialógica. 0 caráter dialógico da proposta exigia, da professora, abertura à insegurança e o convívio com a incerteza de estar bem preparado. Implicava em reflexão constante e de investimento contínuo na própria formação da professora para uma prática distante do ensino de conteúdos tradicionalmente presentes na escola.

\section{RESULTADOS: UMA EPIFANIA}

Em outubro daquele semestre letivo, um dos alunos relatou ter vindo à "cidade" e ser abordado por pessoas falando de Carlos Drummond de Andrade9. Falou à turma de sua vergonha por não conhecer poemas de Drummond, questionou à professora se "esse Drummond era famoso mesmo e se era de Itabira". Organizamos, então, atividades para que os alunos conhecessem Drummond. Uma delas, com Quadrilha ${ }^{10}$, por coincidirem alguns nomes de alunos e presentes no poema.

Registrado em uma cópia, com "letras de fôrma grande" e "letras de mão" - como diziam os alunos - o poema foi-lhes entregue e a professora fez a leitura. Finalizada a leitura, um silêncio profundo na turma, rompido pelo pedido "pode ler de novo, professora", nova leitura, novo silêncio, outra solicitação de repetir a leitura. Ficamos intrigados, pensando nas crianças pequenas, que solicitam repetições de histórias, músicas e filmes e dispostos a repetir quanto fosse solicitado, sem questionamento. Após a quinta repetição, a turma começou a rir, inicialmente tímidos e, sentindo que a professora também ria, riram desbragadamente.

Passada a crise de riso, os alunos foram questionados sobre a experiência com o texto do Drummond. Construímos, então, uma rica aprendizagem. Aprendizagem para os alunos e para a professora. Os alunos comentaram o quanto o poema falava de coisas que viviam, o prazer de identificarem alguns, o próprio nome, outros, o nome do colega ou outras palavras. Comentaram os triângulos amorosos conhecidos na própria comunidade em que viviam, seus desfechos trágicos ou corriqueiros, divertiram-se no compartilhamento de histórias de vidas privadas.

Finalmente, um dos alunos comentou "eu não sabia que poesia podia ser feita com as coisas da vida da gente, professora." Refletiram sobre a dureza de suas vidas, a raiva dos abandonados e como tudo isto se transformara na poesia de Drummond. Foi um momento tão emocionante, tão forte! Uma das alunas, talvez, expressando suas próprias experiências, falou de sua vontade de chorar pensando como parecia que o ruim virava bom e o feio ficava bonito na poesia.

De nossa parte, vivemos estas aulas, tão ricas, tão humanizadoras, registramos as aprendizagens compartilhadas neste texto, vemos o quanto a experiência com aqueles alunos foi marcante e está viva na lembrança. Quanto sentido foi construído para a educação a partir dessa experiência e como esse sentido que traz amorosidade à relação entre professores e alunos, nos iguala na condição de educandos.

Curioso é que produzir este relato, após tanto tempo, impregna-nos de esperança em novos sentidos, pois vejo os sensos ético e estético articulados nessa vivência.

Essa vivência ensina o sentido de uma conscientização profissional que só se dá na prática da escola, no cotejamento das diferenças de conteúdos, objetivos e saberes postos em jogo no diálogo. Mostra como a abertura para repetir o ato de educar não se constitui no fazer do igual, oportuniza testar novas formas de

\footnotetext{
${ }^{9}$ É tradição de Itabira comemorar com eventos variados o aniversário de seu poeta ilustre, muitas vezes com eventos de rua, organizados por escolas ou pela Fundação Cultural Carlos Drummond de Andrade. 0 aluno foi abordado em uma dessas atividades culturais.

103 João amava Teresa que amava Raimundo que amava Maria que amava Joaquim que amava Lili que não amava ninguém. João foi pra os Estados Unidos, Teresa para o convento, Raimundo morreu de desastre, Maria ficou para tia, Joaquim suicidou-se e Lili casou com J. Pinto Fernandes que não tinha entrado na história.
} 
conhecer-ser-tornar-se pessoa humana.

\section{CONSIDERAÇÕES FINAIS}

Streck (2011) estabelece cinco razões para dialogar com Paulo Freire, a primeira das quais já apontada neste texto. As outras razões são a capacidade do pensamento de Freire de conectar coisas diferentes, o caráter transitório de seu pensamento, a capacidade de se reinventar no contexto de mudanças, a largueza e a profundidade de sua obra. As razões apontadas por Streck são importantes na educação que é um exercício de conexão entre diferentes pessoas, interesses díspares, condições desiguais e, por isso mesmo, precisa transitar entre situações instáveis, mutáveis sem perder a profundidade do conteúdo e a sua capacidade de abranger largas diferenças.

A educação subjacente a este texto e implicada com a perspectiva freireana não se constrói de uma só vez, nem com uma atividade ou com um conjunto de procedimentos didáticos tecnicamente articulados. A educação que congrega o filósofo, o trabalhador rural, o professor inexperiente, a professora estudiosa, a dona de casa, o analfabeto é aquela que pretende as pessoas de mãos dadas. Uma educação que repete sucessivamente o seu fazer sempre considerando a dimensão criativa da pessoa humana. A educação que pretende uma utopia chamada qualidade, para a qual são necessárias muitas e muitas repetições, muitas e muitas experiências compartilhadas. Chamemos Drummond para finalizar este texto "o presente é tão grande, não nos afastemos. Não nos afastemos muito, vamos, de mãos dadas."

\section{REFERÊNCIAS}

[1] Andrade, Carlos Drummond. Nova reunião. Rio de Janeiro: J. Olympio, 1985.

[2] Brasil. Diretrizes Curriculares Nacionais para a Educação de Jovens e Adultos. Parecer 11/2000. Brasília. 2000.

[3] Freire, Paulo. Política e educação: ensaios. São Paulo, Cortez, 1993. (Coleção Questões de Nossa Época; v.23).

[4] Freire, Paulo. Educação como prática da liberdade. 23a ed. Rio de Janeiro: Paz e Terra, 1999.

[5] Freire, Paulo. Pedagogia da Esperança: Um reencontro com a Pedagogia do Oprimido - Notas: Ana Maria Araújo Freire. Rio de Janeiro: Paz e Terra, 1992.

[6] Streck, Danilo Romeu. Cinco Razões Para Dialogar Com Paulo Freire. Revista e- Curriculum, [S.l.], v. 7, n. 3, nov. 2011. ISSN 1809-3876. Disponível em: <https://revistas.pucsp.br/index.php/curriculum/article/view/7595>. Acesso em: 10 out. 2017. 


\section{Capítulo 8}

Possibilidades da educação de jovens e adultos como espaço de afirmação sob a perspectiva do gênero

\section{Erlando da Silva Reses \\ Walace Roza Pinel \\ Lenilda Damasceno Perpétuo}

Resumo: 0 presente artigo busca trazer ao debate as discussões de gênero e as relações assimétricas e desiguais construídas historicamente no contexto da Educação de Jovens e Adultos - EJA, utilizando como base teórica princípios dos movimentos de Cultura e Educação Popular e suas manifestações próprias, perfazendo um diálogo permanentemente com o currículo escolar a as possibilidades de emancipação. De acordo com Pinel (2018) buscando o diálogo com Boito (2016) em uma análise retrospectiva com base histórica e materialista acerca do papel da mulher na constituição das sociedades humanas, há uma pergunta central que deve ser feita aos pensadores marxistas sobre a questão da opressão da mulher: Na perspectiva dos interesses da classe proletária, na luta pelo socialismo, como devemos abordar a questão da opressão da mulher?

Palavras-chave: Educação de Jovens e Adultos; Gênero; Educação Popular 


\section{INTRODUÇÃO}

A Educação de Jovens e Adultos (EJA) - no contexto da Educação Popular - como modalidade específica busca dialogar com pessoas, grupos, unidades sociais, movimentos e classes populares, tomando-os como criadores, autores e atores de formas e sistemas de práticas, saberes, sentidos, significados, sensibilidades e sociabilidades diversas e culturalmente diferentes daqueles até então considerados como: "civilizados", "acadêmicos", "eruditos" "legítimos" (Brandão, 2012). Defendemos que o diálogo trata-se de uma possibilidade pedagógica que traz o debate acerca das relações de assimetria e desigualdade de gênero na sociedade capitalista que se reflete na EJA.

Torna-se necessária - a esta modalidade de ensino - uma discussão sobre a temática de gênero, na intenção de perceber as múltiplas determinantes que naturalizam as relações de assimetria e desigualdade entre os gêneros e assim, por meio do diálogo e da conscientização, auxiliar na construção de relações simétricas e de partilha entre homens e mulheres seja dentro ou fora do ambiente escolar, social, procurando desnaturalizar as relações de opressão na sociedade, especialmente nas comunidades escolarizadas por meio desta modalidade destinada à classe trabalhadora historicamente oprimida.

\section{RELAÇÕES DE GÊNERO ENQUANTO CONSTRUÇÕES SOCIAIS}

De acordo com Pinel (2018) - buscando o diálogo com Boito (2016) - em uma análise retrospectiva com base histórica e materialista acerca do papel da mulher na constituição das sociedades humanas, há uma pergunta central que deve ser feita aos pensadores marxistas sobre a questão da opressão da mulher: $\mathrm{Na}$ perspectiva dos interesses da classe proletária, na luta pelo socialismo, como devemos abordar a questão da opressão da mulher? Assim, procurando responder à sua indagação, defende a autora que apenas a organização da classe operária, pelo fim do capitalismo, pode dar lugar à luta contra sua opressão.

Como exemplo cita a Comuna de Paris que, imediatamente, após a tomada do poder, estabeleceu com o protagonismo da classe operária, no processo de luta entre suas primeiras medidas, a criação de creches e a igualdade de salários entre homens e mulheres. Cita, ainda, que foi na Revolução Russa em 1918 que foram estabelecidas a licença maternidade e o direito ao voto feminino. Rosa Luxemburgo faz clara distinção do papel da mulher do povo na constituição social ao longo dos tempos, e de sua relação imemoriável com o mundo do trabalho:

A mulher do povo teve de trabalhar desde sempre. Na horda bárbara ela carregava o peso, coletava alimentos; no povoado primitivo, plantava e moía o cereal, fazia panelas, na Antiguidade, como escrava, servia aos senhores, na Idade Média fiava para o senhor feudal. (Luxemburgo apud Boito 2016, p. 96)

Para a intelectual-ativista, as mulheres proletárias ocupam papéis sociais distintos ao longo da história, diferença que é acentuada na sociedade burguesa. Ela complementa que, para o pensamento marxista, não basta apenas a igualdade de direitos das mulheres, mas uma discussão sobre o papel da dominação capitalista nas relações econômicas, as quais se refletem nas relações sociais de igualdade de direitos das mulheres as quais não derrubam o Estado, e não tocam na dominação do capital (Luxemburgo apud Boito, 2016, p. 97).

Nessa perspectiva, para Lowe (1995), qualquer tentativa de estudar as relações de gênero precisa avançar além da descrição da evolução de "diferenças culturais" (entre mulheres, ou entre mulheres e homens) e da constatação abstrata da construção social das relações de gênero. Ou seja, para o pesquisador, somente após extrapolar esses dois princípios é que será possível investigar tais relações como elementos da política econômica atual, implicadas numa dinâmica global de dominação de nações e classes sociais e de mercantilização da vida.

Procura-se nesse trabalho, portanto, uma análise de gênero na perspectiva de retomada da luta das classes trabalhadoras, a qual intenciona colocar fim ao sistema capitalista estruturado nas assimetrias propositais e conjunturais entre despossuídos e despossuídas, entre explorados e exploradas por exploradores e exploradoras das classes possuidoras do capital e dos bens de produção, e suas necessárias estratégias e possibilidades de luta pela emancipação da mulher proletária enquanto classe social.

Sob essa ótica, para Luxemburgo (2016), a mulher trabalhadora, ao longo da história, é a coluna mestra de sustentação de um sistema de dominação e exploração de mais valia do proletariado, sendo diretamente atingida pelo sistema capitalista de produção. Passamos neste momento a discussão específica sob o papel da mulher sob a perspectiva do gênero. 


\subsection{A MULHER DA EJA SOB O ENFOQUE DO GÊNERO}

Acerca do processo de conscientização coletiva, entendemos que esta consciência precisa ser construída em relação entre homens e mulheres sendo pautada sob os princípios da Educação Popular (EP) que se projeta nas propostas de EJA, qual seja: o diálogo, na perspectiva freireana. Paulo Freire (1996) entende o Homem e a Mulher como seres inconclusos que se constituem historicamente, mas, envolvidos em um constante processo de transformação, em que aprende, ensina e se refaz no diálogo e na experiência real com o outro, constituindo assim sua forma de agir no mundo, sua consciência. Como seres históricos entendemos que "somos seres condicionados, mas não determinados". Reconhecer que a História é tempo de possibilidades e não de determinismo, que o futuro. Este artigo constitui-se como uma pesquisa qualitativa, construída por meio da associação da pesquisa bibliográfica com a vasta experiência dos autores na docência com jovens e adultos na rede pública do Distrito Federal.

Dialogando sob a perspectiva de Gênero, trata-se de um conceito permanentemente em disputa, que no início de sua utilização destacou aspectos de

diferenciação biológica entre homens e mulheres, mas, que ao longo do tempo recebeu distintas definições. Alinhados, a pesquisadoras feministas da década de 70, que buscaram estabelecer fronteiras entre a construção de gênero não apenas em seus aspectos biológicos, mas, considerando os aspectos culturais e sociais, entendemos a categoria gênero como "elemento constitutivo de relações sociais fundadas sobre as diferenças percebidas entre os sexos (...) primeiro modo de dar significação às relações de poder" (CARREIRA, 2014, p. 198 apud SCOTT, 1995).

Neste sentido, entende Saffioti (1994) que os sujeitos e sujeitas históricos (as) têm suas relações reguladas pelo gênero, conjunto de representações absolutamente central na sociedade. A EJA no Brasil constitui-se como uma modalidade de ensino destinada ao atendimento de jovens e adultos histórica e socialmente impedidos do acesso regular a educação e a cultura. Oliveira (2001, p. 15-16) faz uma instigante caracterização deste público:

0 adulto para a EJA não é o estudante universitário, o profissional qualificado que frequenta cursos de formação continuada ou de especialização, ou a pessoa adulta interessada em aperfeiçoar seus conhecimentos em áreas como, por exemplo, artes, línguas estrangeiras ou música. (...) E o jovem não é aquele com uma história de escolaridade regular, vestibulando ou aluno de cursos extracurriculares em busca de enriquecimento pessoal. Não é também o adolescente no sentido natural de pertinência a uma etapa Relação assimétrica entre homem e mulher e o diálogo como processo educativo

Antes de destacar algumas determinantes que socialmente instituem papeis e funções sociais distintas aos homens e mulheres que acessam a EJA, faz-se necessário entender quem são esses homens e mulheres, algumas especulações sobre a influência da categoria trabalho na questão de gênero ao longo da história capitalista. Infere o autor acerca da divisão sexual do trabalho que às mulheres desde o início da revolução industrial era reservada uma carga horária maior na dupla jornada fábrica-lar, na grande expansão industrial, os processos produtivos reais atenuavam ou mesmo aboliam as diferenças no trabalho entre homens e mulheres, com efeitos de longo alcance nos papéis sociais, sexuais e nas convenções dos sexos. (HOBSBAWM, 2005, p. 154).

À mulher trabalhadora - tendo passado pela gravidez precoce, ou não, é socialmente responsável pelos cuidados da casa, é tradicionalmente conhecida como "dona da casa", no sentido de garantir a organização do espaço familiar e os "cuidados e educação dos filhos". A esta mulher é atribuída duplas, triplas, ou seja, múltiplas jornadas. A sociedade do capital apoiada nas bases da exploração e subordinação operou processo de "naturalização" de práticas socioculturais em que a mulher, mesmo inserida no mercado de trabalho, sempre está atrelada ao ambiente doméstico.

$\mathrm{Na}$ esteira do pensamento marxista - compreendendo-se que a perspectiva principal de análise deve ser a análise na perspectiva da luta de classes - compartilha-se, nesse trabalho, do pensamento de Saffioti (1991), entendemos que o gênero, como categoria, deve ser compreendido como uma construção social, afastado do naturalismo, sendo constituído e mediado pela cultura, procurando por meio da luta política a igualdade social das categorias discriminadas, reconhecendo a diferença entre homens e mulheres entendendo-as como fruto de uma convivência social mediada pela cultura.

Procura-se, de forma dialética, analisar os conceitos de diferença e igualdade de forma totalitária, no qual ambos devem ser pensados de forma dialética sendo partes de um todo.

Atribui-se aqui o mesmo valor a igualdade e a diferença, na medida que não constituem-se um par dicotômico, mutuamente exclusivo, mas são cada um a condição do outro. Ademais, similariedade e diferença são duas dimensões de 
um mesmo processo, razão pela qual não se pode mencionar uma na ausência da outra, a diferença é senão a outra face da identidade. (Saffioti, 1991, p. 53)

Kollontai (1976), ainda durante a Revolução Russa, se questiona sobreo papel da mulher nas sociedades burguesas: Qual objetivo das feministas burguesas? Seria conseguir os mesmos direitos na sociedade capitalista que possuem os homens? Procurando responder sua própria indagação, avança a pensadora e ativista russa: os caminhos seguidos pelas mulheres proletárias e as feministas burguesas separaram-se há tempos. Há uma grande diferença entre seus objetivos.

Entretanto, respeitando a tradição dialética e contraditória do método marxista, cabe salientar que mesmo durante o período soviético as relações de poder entre os gêneros não foram totalmente superadas, a própria Kollontai, segundo Luedemann (2017) - apesar de publicamente em 1930 defender no seu "exílio" como embaixadora na Noruega a liderança Estalinista - denunciou em muitos dos seus contos e novelas a situação da família soviética depois da revolução. Em sua obra Irmãs que retrata mulheres da mesma condição: a dona de casa e a prostituta, exploradas pela figura opressora do patriarca da família burguesa.

Era terrível constatar que em vez de a mulher soviética conquistar o direito à vida pública, com o trabalho fora do lar, ela apenas aumentou sua jornada de trabalho: dentro e fora de casa. Não era mais "prisioneira" do próprio lar, era também da fábrica, da fazenda coletiva, do escritório burocrata. 0 direito patriarcal mantinha-se com a mesma força do passado. Era o pai o marido quem devia decidir sobre a vida e a morte dos filhos e da esposa. Dificilmente essa realidade foi alterada. Mesmo com o aumento das creches, a mulher continuou a assumir sozinha, os deveres e o cuidado com a casa. (Luedemann, 2017 p.202)

Verticalizando a discussão à participação dos homens nos estudos relacionados a gênero, em uma perspectiva anti-hegemônica, mesmo nos países capitalistas centrais, surge Giffin (2005), em uma análise do movimento feminista que desabrocha na sociedade norte-americana, o qual defende que mesmo durante os primeiros anos do ressurgimento do feminismo, nos anos 60, e do início dos "estudos das mulheres", antes do desenvolvimento do conceito de gênero, havia homens interessados em participar da reflexão sobre essas questões, e ilustra, também, como o gênero está envolvido com uma forma de estruturar a prática social em geral.

Na confrontação entre Homem e Mulher nas relações sociais, fossem na esfera doméstica ou na pública, as vantagens todas, segundo os valores dominantes da sociedade individualista, competitiva e monetarizada do capital, pareciam ser dos Homens. Daí a importância de estudar as relações dialéticas de aliança, dominação, e subordinação que constroem as masculinidades e feminilidades.

0 gênero se envolve com uma forma de estruturar a prática social em geral, e se funde com outras estruturas sociais tais como classe,raça, nacionalidade ou posição na ordem mundial, e concerne questões de justiça social. Isso quer dizer que, para entender o gênero, portanto, precisamos constantemente ir além do gênero (GIFFIN, 2005, p. 54, grifo nosso).

Seguindo essa linha de raciocínio, a autora considera o quão importante é a entrada dos homens nos estudos de gênero, o que representa uma oportunidade muito bem-vinda de valorizar outras perspectivas - coerente com a importância dada na epistemologia feminista à natureza sempre parcial e situada dos conhecimentos, que devem ser vistos e contextualizados historicamente.

Ela destaca, ainda, um estudo do qual participou homens, tanto gays quanto heterossexuais, e que possui como questão central o "poder", enfatizando, portanto, a constante modificação dos padrões de dominação, a internalização de estruturas sociais de opressão e poder, perpassando a necessidade e dificuldade de entender a inter-relação entre opressão no nível individual, além das grandes estruturas sociais, políticas, econômicas e ideológicas baseadas na hierarquia e nos privilégios. A autora, entretanto, faz uma significativa ressalva, e destaca que os mesmos homens que são privilegiados pelo "poder" são, também, marcados e brutalizados pelo mesmo sistema do qual se beneficiam.

Chegamos às últimas linhas deste trabalho procurando apontar para um cenário, sob a ótica freireana baseada no diálogo e entendimento mútuo, procurando uma ação pedagógica emancipadora de pessoas especialmente das mulheres estudantes da Educação de Jovens e Adultos.

\section{CONSIDERAÇÕES FINAIS}

Neste artigo procuramos em sua primeira parte um diálogo com os conceitos de educação popular, buscando, a partir desta primeira leitura, um enfoque específico sobre a mulher e sua condição na perspectiva do gênero. Neste momento, a partir de uma análise socioeconômica e histórica na realidade da 
Educação de Jovens e Adultos, propomos atenção especial às análises e discursos ligados à temática do gênero e suas relações como categoria essencial de análise, não deixando em segundo plano a importância dos contextos sociais.

Partilha-se do entendimento de Bandeira e Suárez (1999, p. 21) que consideram a desigualdade social, a irredutibilidade das diferenças, o exercício abusivo do poder, a pobreza e a miséria possuem papel explicativo fundamental em uma microanálise centrada no sujeito social. No atual cenário políticoideológico e pedagógico de amplo retrocesso debate acerca de questões ligadas às temáticas de gênero no campo das políticas educacionais, representado - entre outros - pelo autoritário Projeto Escola Sem Partido, procura-se o diálogo, com bases nos ideais progressistas das epistemologias educacionais, a reafirmação da importância da perspectiva de gênero nos estudos e pesquisas que acompanham a Educação de Jovens e Adultos, esta entendida como uma educação popular, feita a partir das perspectivas da classe trabalhadora, que após sua jornada de trabalho busca na escola um espaço de reconhecimento e atenção voltada às necessidades pedagógicas e sociais que devem estabelecidas neste espaço de convivência plural e múltiplo da Escola Pública.

Procuramos, no presente estudo, traçar paralelos entre os papeis sociais desempenhados por homens e mulheres no trabalho e na educação de matriz capitalista, buscando compreender o momento educativo da EJA enquanto possibilidade emancipatória, servindo à construção e reconstrução dialética constitutiva dos papeis sociais nos mosaicos das relações humanas, onde a alteridade e as transformações nas relações de assimetria e desigualdade de gênero, especialmente na EJA, devem estar sempre presentes nas práticas educativas, a partir da perspectiva onipresente do diálogo enquanto elemento constitutivo e fundamental na educação.

\section{REFERÊNCIAS}

[1] Bandeira, Maria Lourdes, Suarez, Violência, Gênero e Crime no Distrito Federal, Brasília, Ed. UnB, 1999

[2] Brandão, Carlos. A educação popular antes e agora: lembranças de ontem, perguntas para agora. São Paulo,

2012.

[3] Boito, Misa. A luta contra a opressão da mulher: recuperando uma abordagem de classe. São Paulo: Nova Palavra. 2016. 9 - 96 p.

[4] Carreira, Denise. Gênero e Raça: a EJA como política de ação. In: JR, Catelli Roberto.

[5] Freire, Paulo. Pedagogia da Autonomia: saberes necessários à prática educativa. São Paulo: Paz e Terra, 1996

[6] Giffin, K. A inserção dos homens nos estudos de gêneros: contribuições de um sujeito histórico. In: Revista Ciência e Saúde Coletiva. Rio de Janeiro: Fiocruz, 2005. 49 - 54 p. Hobsbawm, Eric: Pessoas Extraordinárias, Homem e Mulher: Imagens da Esquerda. São Paulo: Paz e Terra, 2005.

[7] Kollontai, Aleksandra; Marxismo e revolução sexual. 1976 Ed. Parma. LOWE, David. The body in latecapitalist. Londres: Duke University Press, 1995.

[8] Luedemann, Cecília. Anton Makarenko, vida e obra - a pedagogia na revolução. [S.l]: Expressão Popular, 2017.

[9] Oliveira, M. K. de. (2001). Jovens e adultos como sujeitos de aprendizagem. In: Ribeiro, V. M. (Org.) (2001). Educação de Jovens e Adultos: novos leitores, novas leituras. Campinas: Ação Educativa. (Coleção Leituras no Brasil),

[10] Pinel, Walace Roza. Educação nas Prisões para Mulheres em Brasília - DF. Brasília, Ed. Novas Edições Acadêmicas, 2018.

[11] Saffioti, Heleneith. O poder do macho. 2º. ed. São Paulo: Moderna, v. 10, 1987 (Projeto Passo à frente, Coleção polêmica).

[12] Heleneith. Conceituando o Gênero. In: Gênero e Educação. Coordenadoria Especial da Mulher. Secretaria Municipal de Educação. São Paulo, 1991 


\section{Capítulo 9}

\section{Inclusão nas instituições de ensino superior (IES) no Brasil}

\section{Suzana Arleno Souza Santos}

Adriana Pires de Arezzo

Simone Garrido Esteves Cabral

Julio Cesar Mello D'Amato

Resumo: Este trabalho pretende oferecer uma reflexão acerca da educação, na sua busca, cada vez maior, de incluir aqueles que são considerados diferentes. Especialmente, volta-se para a inclusão de portadores de espectro autista. 0 perfil autista tem sido encontrado, cada vez mais frequentemente, nas instituições de ensino superior. Neste trabalho apresentamos dois casos de alunos dos cursos de licenciatura, mais especificamente História e Pedagogia, que apresentam diferenças quanto ao tipo de autismo, mas que está exigindo de toda a comunidade acadêmica buscar formas e maneiras de cada vez mais realizar a inclusão no cotidiano das instituições de ensino superior. Vale dizer que os alunos têm sido observados nos desempenhos: relacional e de aprendizagem. Todas as propostas de ações são amplamente discutidas pela comunidade acadêmica que tenta determinar quais os passos que precisam ser dados a seguir, avaliando-os constantemente. Esse processo tem contado com algumas dificuldades, considerando que em alguns momentos, foi possível sentir resistência das famílias, principalmente, quando os alunos apresentaram alguma dificuldade quanto ao seu aprendizado. Nestes, tentou-se convencer o núcleo familiar de que é preciso, com respeito à realidade individual, exigir do aluno, o máximo que ele possa oferecer. Afinal, trata-se de inclusão e pressupõe a chance de formar profissionais com mais possibilidades para o mercado, de acordo com o Decreto no 3298/99, que dispõe sobre a Política Nacional para a integração da pessoa portadora de deficiência no Brasil. Ao longo do texto apresentamos os elementos da legislação brasileira sobre a temática, bem como se discute a grande importância de cada família no desenvolvimento desses alunos. 0 interesse pelo tema surgiu a partir do trabalho do Núcleo de Acompanhamento Psicopedagógico dos Alunos (NAPPE) que funciona na UNILASALLE/RJ e realiza pesquisas desde 2015, analisando, acompanhando e refletindo sobre as diferentes demandas dos alunos de instituições de ensino superior.

Palavras chave: Inclusão; Ensino Superior; Educação| 


\section{INTRODUÇÃO}

A educação inclusiva nas Instituições de Ensino Superior (IES), além de cada vez mais ser pauta de discussão frequente no meio acadêmico, se faz presente, configurando-se como uma realidade a ser aprimorada, uma vez que reconhece a diversidade, promovendo sua aceitação, configura um dos grandes desafios do mundo contemporâneo.

Nesse sentido, a chegada, cada vez mais frequente, de alunos com necessidades específicas, explica-se porque esses são os alunos egressos de um processo gradativo de inclusão em escolas regulares, no Brasil, desde a educação infantil até o Ensino Médio. Esse processo começa a acontecer a partir da promulgação da Constituição Federal de 1988, que em seu Artigo 208 trata da Educação Básica obrigatória e gratuita, indicando, inclusive, a inserção dos deficientes, ao afirmar que é dever do Estado garantir "atendimento educacional especializado aos portadores de deficiência, preferencialmente, na rede regular de ensino" (BRASIL, CF, 1988, Art. 208). Embora ainda que a Constituição Federal não tenha indicado a obrigatoriedade desse atendimento aos portadores de deficiência, começa-se a configurar a gradativa inserção destes nas escolas regulares de ensino. Essa tendência toma corpo a partir da LDB, Lei de Diretrizes e Bases da Educação, Lei no 9394/96, que traz um capítulo específico sobre Educação Especial, em que também afirma o atendimento preferencial em escolas regulares (Art. 58, Capítulo V).

Nessa mesma linha, tem-se o Decreto no 3298/99, que dispõe sobre a Política Nacional para Integração da Pessoa Portadora de Deficiência que, em sua Seção II, Art. 24, item VI, §3oㅡ, indica que "A educação do aluno com deficiência deverá iniciar-se na educação infantil, a partir de zero ano".

A Resolução CNE/CEB № 2, DE 11 DE SETEMBRO DE 2001, trouxe o indicativo mais contundente em relação à matrícula dos alunos com necessidades específicas: "Os sistemas de ensino devem matricular todos os alunos, cabendo às escolas, organizar-se para o atendimento aos educandos com necessidades educacionais especiais, assegurando as condições necessárias para uma educação de qualidade para todos" (Art. 2ㅇ).

É importante destacar que o Parecer CNE/CEB 17/2001 destaca-se por sua abrangência, indo além do Ensino Básico, referindo-se também, em seu item 4, à inclusão na Educação Superior. Além disso, para além da presença física, esse Parecer destaca que

A política de inclusão de alunos que apresentam necessidades educacionais especiais na rede regular de ensino não consiste apenas na permanência física desses alunos junto aos demais educandos, mas representa a ousadia de rever concepções e paradigmas, bem como desenvolver o potencial dessas pessoas, respeitando suas diferenças e atendendo suas necessidades (CNE/CEB 17/2001, item 4).

Tem-se, ainda, em 2008, como um importante marco regulatório, a Política Nacional de Educação Especial na perspectiva da educação inclusiva que garante a matrícula das pessoas com deficiência na escola regular, indicando, então, um ponto de partida, a educação especial, e assinalando um ponto de chegada, um objetivo, que é a educação inclusiva. Dessa forma, com o acréscimo de Decretos, Pareceres e Resoluções além do Plano Nacional dos Direitos da Pessoa com Deficiência, a inclusão torna-se direito inquestionável e uma questão indiscutível, bem como imprescindível na educação do país, estendendo, agora, ao Ensino Superior, especialmente, porque esses alunos atendidos na Educação Básica encontramse em fase de ingresso no Ensino Superior.

No entanto, é importante destacar que como a inclusão de pessoas com necessidades específicas ainda é um dado recente, no caso do Ensino Superior, as IES encontram-se imersas em dúvidas e questionamentos, mas é preciso que se diga que esse é um momento de construção.

Neste sentido, como alento, Hegel ensina quando diz:

Tudo o que existe é conhecível e se traduz em categorias universais. Isto importa, para Hegel, em afirmar que ser e conhecer são a mesma coisa. E sem afirmar essa identidade entre Ser e Conhecer, Hegel acha que não poderia afirmar que tudo o que existe é traduzido em universais e idêntico a estes universais. (NÓBREGA, 2007, p.64)

Nessa perspectiva, o presente relato de experiência se refere à inclusão de alunos, com necessidades educativas específicas no Centro Universitário La Salle/RJ - UNILASALLE/RJ -, Instituição de Ensino Superior Confessional, construindo uma narrativa, a partir dos questionamentos, sugestões e soluções dos professores, da instituição, dos próprios alunos e seus familiares. 
A inclusão promovida pela Instituição conta com o apoio do NAPPE (Núcleo de Atendimento Psicopedagógico), um espaço institucional de escuta, por excelência, com vistas a encaminhamentos que tornam o cotidiano do aluno possível, de acordo com o que de melhor a Instituição Lassalista pretende oferecer.

Ao longo dos anos, o Núcleo vem se tornando uma referência para todos que acreditam que este trabalho, ao lado da direção, coordenações, professores e funcionários bem representa a proposta maior de formação da Instituição. Promover Educação é, antes de tudo, acreditar que nossa condição de humanos passa pelo receber, respeitar e nos solidarizar frente à toda a diversidade humana e suas vicissitudes.

O Centro Universitário LaSalle/RJ inseriu-se na vida desses alunos como uma importante contribuição no caminhar, que, espera-se, seja de sucesso em suas trajetórias de vida e na constituição de uma profissão.

\section{0 QUE PRETENDE A INCLUSÃO?}

A Educação se caracteriza por lidar com o que parece impossível, ou pelo menos, distante de uma realização mais fácil. Muitos são os questionamentos e, entre tantos, a proposta de incluir cidadãos todo o tempo, aparece como uma questão a ser enfrentada. Este texto vem se somar a outras tentativas de refletir acerca do que se pretende com a inclusão no universo da educação.

0 homem deve saber que de nenhum outro lugar, mas do encéfalo, vêm a alegria, o riso e a diversão, o pesar, o ressentimento, o desânimo, que adquirimos sabedoria e conhecimento, e enxergamos e ouvimos e sabemos o que é justo e injusto, o que é bom e o que é ruim, o que é doce e o que é amargo...E pelo mesmo órgão, tornamo-nos loucos e delirantes, e medos e terrores nos assombram... Todas estas coisas suportamos do encéfalo quando não está sadio...;Neste sentido sou da opinião de que o encéfalo exerce poder sobre o homem. (Hipócrates - Acerca das Doenças Sagradas, Século IX a. C. apud RELVAS, 2011, p.22).

As patologias de ordem neurológicas e psiquiátricas sempre impuseram uma grande dificuldade à construção do conhecimento. Este texto se volta para o espectro autista e toda uma construção neurológica que envolve a questão. Defende, claramente, o direito de seus sujeitos frequentarem e serem incluídos no sistema educacional, respeitando-se suas características.

Afinal, consideramos importante definir o que se entende por inclusão. Nesta medida, talvez seja prudente diferenciar inclusão social e inclusão na educação no que diz respeito à formação profissional.

É possível perceber alguma coisa que se precisa pensar. Assim, é saudável incluir todos os indivíduos, independentemente de suas características individuais. 0 que parece fundamental é a necessidade de se definir se a inclusão escolar prescinde ou pode negligenciar o acesso a conteúdo em geral, exigidos à maioria daqueles que abraçam uma determinada área de conhecimento.

a humanidade sempre sonhou com um milagre religioso: que os cegos enxergassem e que os surdos ouvissem. É provável que a humanidade triunfe um dia sobre a cegueira, a surdez e a deficiência intelectual. Porém as vencerá no plano social e pedagógico muito antes que no plano biológico e medicinal. É possível que não esteja longe o dia em que a pedagogia se envergonhe do próprio conceito de "criança com defeito". O surdo falante e o trabalhador cego, participantes da vida geral em toda a sua plenitude, não sentirão sua deficiência e não darão motivos para que os outros a sintam. Está em nossas mãos o desaparecimento das condições sociais de existência desses defeitos, ainda que o cego continue cedo e o surdo continue surdo. Provavelmente não serão compreendidos aqueles que disserem que um cego é deficiente, assim, as pessoas dirão que um cego é um cego, que um surdo é um surdo, e nada mais" (VYGOTSKY, 1989, p.82)

Este, sem dúvida, constitui um terreno difícil de discussão, pelo risco que pode suscitar em muitas pessoas a suposição de tratar-se de alguma reedição de velhos critérios de exclusão. A intenção deste artigo não é essa, mas sim, chamar a atenção de todos para as saídas que se deve oferecer àqueles indivíduos que, em suas particularidades, apresentam dificuldades reais de aprendizagem. 
Nossa instituição tem se debruçado sobre o como fazer para incluir com responsabilidade. Salvo melhor juízo, acreditamos que a inclusão de todos os sujeitos precisa ser defendida, mas temos nos recusado a crer que nosso trabalho termine quando os diferentes indivíduos integram a instituição, mesmo que o aproveitamento de parte destes não alcance aquilo que poder-se-ia considerar suficiente.

Acreditamos, portanto, que os indivíduos considerados diferentes precisam ser incluídos, inclusive, no sentido de alcançarem o máximo de aprendizagem. A chance de interpretá-los, particularmente, se coloca com um desafio. Ainda assim, na perspectiva Vygostskyana, o conceito de Zona de Desenvolvimento Proximal (ZDP) ${ }^{11}$ nos mostra que, com a ajuda do outro - adultos, professores, colegas mais capazes - a pessoa terá possibilidades de produzir mais do que produz sozinha. Nesse sentido, esse conceito nos aponta para que o foco do ensino/aprendizagem esteja voltado para o que a pessoa com deficiência tem em potencial, para suas potencialidades ainda não realizadas, reforçando a ideia de que "Todas as crianças podem aprender e se desenvolver... as mais sérias deficiências podem ser compensadas com ensino apropriado, pois, o aprendizado adequadamente organizado resulta em desenvolvimento mental" (VYGOTSKY, 1989, p.94)

Muitas são as características que diferenciam umas de outras pessoas, portadores ou não de características de uma determinada patologia. Em relação a necessidades físicas especiais, as condições de nossa Instituição têm sido bastante suficientes para acolher alunos que a procuram. No que diz respeito à atuação de todos os que nela trabalham, é importante um investimento constante em estudo, debates e procura, sempre, por estratégias melhores à cada situação.

Nossa experiência tem demonstrado que a mesma patologia acolhe possibilidades bem diferentes, colocando-nos em situações, por vezes, insegura. Como fazer para não aprovar aquele que não aprende. Como agir, evitando que os envolvidos se considerem não merecedores de inclusão?

o autismo infantil é uma síndrome clínica, com alguns sintomas de base e uma variedade infinita de intensidades relativas e de variação secundárias. Ele considera fatores etiológicos intrínsecos orgânicos (constitucionais e adquiridas) e psicológicos ambientais como um continuum, com um número quase infinito de combinações possíveis, comportando, em um extremo, uma etiologia intrínseca completa e, no outro, uma etiologia completa ambiental. Ele acha útil dividir a etiologia autista em quatro grupos. Os dois primeiros corresponderiam a uma vulnerabilidade de predisposição, os dois últimos são secundários a um impacto ambiental. (RUTTEMBERG apud AJURIAGUERRA, 1971, p.701)

Este é um limite de decisão que precisa ser amplamente discutido por educadores e demais profissionais da aprendizagem. Não se pode crer que incluir seja reduzido a tratar bem, a permitir que todos frequentem os mesmos lugares, entre eles, o ambiente de aprendizagem.

É preciso construir propostas dinâmicas de aprendizagem que também possam atender às necessidades dos alunos, sem negligenciar os demais. Alguns exemplos de propostas são: apresentação de pesquisas; seminários em grupo; oficinas que exigiram a interação dos alunos e a demonstração satisfatória de um resultado; Metodologias ativas, dentre elas, sala de aula invertida e aprendizagem por projeto; avaliação adaptada e/ou oral.

Apresentamos, portanto, dois relatos de experiência, que introduzem narrativas de um momento de aprendizado que não se esgota nela de alunos, professores e instituição. Escolhemos para esta oportunidade os exemplos de dois alunos, integrantes daquilo que, hoje, é considerado "espectro autista".

\subsection{RELATO DE EXPERIÊNCIA: NARRATIVAS DE ALTERIDADE}

Os dois casos analisados entraram em contato com o NAPPE desde o momento de chegada na Instituição lassalista, através das coordenações de cursos e da Reitoria sendo realizada uma entrevista inicial com os pais dos alunos e os alunos posteriormente, na reunião de colegiado dos cursos foram apresentados os

11 Zona de Desenvolvimento Proximal (ZDP), segundo Vigostky é compreendida como a distância entre o nível de desenvolvimento real, que se costuma determinar através da solução independente de problemas, e o nível de desenvolvimento potencial, determinado através da solução de problemas sob a orientação de um adulto ou em colaboração com companheiros mais capazes (VYGOTSKY, 1989). 
casos e o NAPPE realizou uma reflexão sobre cada caso, tirando as dúvidas dos professores, caracterizando suas diferenças.

A presente pesquisa com os casos de espectro autista se baseia na bibliografia e trabalhos existentes sobre o tema e, também, nas observações, conversas com professores, discentes e coordenação nas entrevistas e encontros realizados com as famílias, uma vez que a participação destas é imprescindível, e nas reflexões do grupo de estudos do NAPPE.

Sabemos bem que quando pensamos no "espectro autista" não estamos tratando de apenas um perfil, lembrando-nos de quadros mais ou menos graves da patologia. Parece-nos que a este fato, une-se, principalmente, à experiência de vida de cada pessoa. Deste modo, estamos trazendo, para começar, um pouco da história da aluna "Maria"12 que logo ao chegar, despertou o olhar de muitos pela simpatia e beleza apresentadas.

"Maria", logo começou a interagir com outros alunos do corpo discente, com toda a sua alegria e encantamento pela vida universitária. 0 apoio da família, também, pareceu bem importante. Seus pais durante todo o processo estiveram presentes e totalmente interessados no sucesso da aluna. Segundo as informações por nós recebidas, a aluna gozou de uma educação anterior que a reconheceu como portadora de um autismo considerado leve, permitindo-lhe caminhar a partir de suas características. Logo no início, pareceu a todos que esta experiência seria de grande aprendizagem e que tudo sinalizava uma inclusão com muito bom prognóstico.

Maria apresentou dificuldades com relação às formas de avaliação, tipo prova, com enunciados muito longos e uma série de comandos nas questões. Os professores passaram a organizar provas com o mesmo conteúdo, mas com questões dissertativas mais objetivas, simples em seus enunciados. Ou seja, as provas foram sendo aos poucos adaptadas, conforme as demandas de cada disciplina, em relação a seus conteúdos. Os trabalhos de grupo, inicialmente, eram um problema, pois, a turma incluía Maria no grupo, mas ela não acabava por não participar da realização do trabalho, sendo apenas espectadora. Conversamos com os colegas de turma e com Maria, separadamente, e fomos realizando um trabalho coletivo e colaborativo de maior participação de Maria nas atividades dos grupos, obtendo sucesso. Maria encontrou o seu lugar no trabalho coletivo e passou a contribuir com as atividades, chegando a ser disputada por dois grupos para fazer parte de trabalhos.

Maria atualmente cursa o 5o período da Licenciatura em Pedagogia, muito curiosa, pouco pergunta na aula, mas presta atenção e realiza todas as atividades em sala de aula; quando não consegue terminar em aula, termina em casa e entrega logo no dia seguinte. Tem muita preocupação em não ficar devendo nada para o professor.

A aplicação de metodologias ativas e o desenvolvimento de trabalhos colaborativos estimulou uma maior participação de "Maria" nas atividades e despertou um interesse maior na área de conhecimento, a Pedagogia. No entanto, é importante destacar que professores e turma precisaram juntos perceber o comportamento e os limites de Maria quanto a sua participação na aula. A aluna precisa levantar, ir ao banheiro, beber água em diversos momentos da aula. Mas, ao fazê-lo, procura não desconcentrar a turma, conforme foi conversado com ela.

O segundo exemplo trazido a esta reflexão é de "João". Logo na chegada tivemos a chance de conversar com seus pais que declararam o grande investimento no filho, apostando que este chegará ao doutorado. Ao ouvirem um simples comentário que falava da importância de se respeitar o processo de cada um, esses pais ficaram incomodados e logo quiseram saber se a observação tinha a ver com o perfil do filho, o que foi respondido com alguma coisa do tipo, qualquer pessoa precisa ser respeitada nos seus limites, independentemente de suas características. Este aluno logo demonstrou que costuma estudar bastante e desde sempre deixou claro que seus pais tinham grande chance de ver suas expectativas mais próximas serem atingidas.

"João" estuda muito, está sempre lendo, porém não socializa tão facilmente, apresenta algumas dificuldades de relacionamento com os colegas, sempre queria fazer os trabalhos sozinho, evitava os trabalhos em grupo. Durante as aulas interrompe os professores, sempre perguntando, questionando, colocando-se, mas muitas vezes não deixando a aula andar; ouvindo a reclamação dos colegas. 0 aproveitamento em relação às provas é bom, não há necessidade em preparar uma outra prova especial, pois consegue responder a mesma prova que é aplicada à turma. Porém, João é muito ansioso, pouco conversava e interagia com os colegas, e ao participar da aula sempre se dirigia ao professor; procura por

12 Nomearemos os alunos apresentados no Relato como “Maria’ e “João”, para que suas identidades sejam preservadas. 
alguns professores durante os intervalos entre as aulas, para conversar, mas não conversava com os colegas.

No entanto, essa questão do relacionamento encontra-se em processo de inclusão, tanto dos colegas como o de "João" que já está interagindo mais com eles. Atualmente, quando pergunta alguma coisa aos professores em aula, os colegas procuram complementar sua pergunta ou até mesmo respondê-la. Não mais está havendo impaciência ou desconforto, uma vez que os colegas perceberam que as perguntas de "João" são, muitas vezes, relevantes e podem contribuir para o enriquecimento das aulas.

Em relação à "Maria", apesar de seu comportamento agradável aos olhos de todos, foi imperativo, conviver com sua enorme dificuldade de aprender, diferentemente do "João" que vem se mostrando capaz de um acesso mais fácil ao aprendizado.

Talvez fosse bastante simples compreender os dois casos, considerando que as pessoas são diferentes, definitivamente. No entanto, alguns elementos não podem ser deixados de lado. Um destes fatores diz respeito aos modelos de família, às exigências e expectativas depositadas sobre cada indivíduo, aliado, claro, ao perfil neurológico que integra todos os casos que compõem o "espectro do autismo".

Nas conversas realizadas com a família percebemos que todo o processo passa pela aceitação dos pais, a forma como estes se relaciona frente ao filho com características especiais. Muito importante, ainda, a expectativa depositada nesse filho, como lidam com o preconceito surgido da sociedade em todas as suas representações, bem como a posição do filho entre os irmãos. Não raro os pais se perguntam por que foram escolhidos para um filho considerado diferente. Muitos, de forma reativa, revoltam-se, o que pode servir como preparação para a empreitada que deverão enfrentar.

No caso do João, a família sempre investiu muito na sua formação, criando muitas expectativas quanto ao seu desempenho acadêmico. João está no $3^{\circ}$ período da Licenciatura em História e seus pais esperam que ele chegue ao Doutorado, consequentemente, João se prepara para isso.

A família de Maria investe muito na sua formação, acompanha, está sempre disponível para ajudá-la a atravessar todos os obstáculos que se interponha na sua trajetória acadêmica, porém não cria expectativas além dos seus limites, estão felizes com as conquistas da filha e vão construindo essa trajetória junto com ela, escutando suas demandas e necessidades e acatando-as, conforme o possível.

Todos sabemos o quanto a construção da subjetividade diferencia os indivíduos e não seria diferente em relação ao tipo considerado patológico. Assim, uma hipótese aqui levantada é da de que independentemente da gravidade de cada quadro de autismo, parece-nos que faz toda a diferença a experiência familiar vivida. A forma como a família entende o processo de inclusão e inserção dos seus filhos na instituição educacional e qual o papel da comunidade escolar na construção social do seu filho é de fundamental importância, para a sua formação acadêmica. Precisamos lembrar que João e Maria estão buscando construir uma possível atuação profissional em suas devidas áreas.

A preocupação com a função da família no processo de cada aluno era uma das muitas preocupações de La Salle, como se observa a seguir: "Fazer com que os pais compreendam a obrigação de darem instrução aos filhos e o prejuízo que lhes causam ao não lhes darem oportunidade de aprenderem a ler e escrever e o quanto isso lhes pode ser danoso, pois nunca serão capazes de nenhum emprego" (LA SALLE apud Rangel E Weschenfelder, 2010, p.59).

Não se quer, absolutamente, crer que, no exemplo do João, o grupo familiar foi mais eficiente, mas supor que a enorme ansiedade pode ter influenciado e subvertido, de certa maneira, o processo do aluno. Cabe reconhecer que essa hipótese inicial não exclui a possibilidade de outros sintomas aparecerem no aluno que melhor aprende. Por exemplo, o João parece ansioso, relaxando pouco, exigindo-se demais, o que pode ter aspectos negativos, se considerarmos sua experiência de vida, no geral. Neste ponto, Maria mostrou-se sempre mais serena, encantada com as relações estabelecidas no novo ambiente.

O NAPPE continua trabalhando na busca de melhores formas de aprendizado para atender às expectativas de Maria e João e suas famílias quanto aos seus desempenhos nas disciplinas, mas também, quanto ao seu processo de socialização junto à comunidade acadêmica, sempre em contato com os professores e coordenação dos cursos. Em reuniões periódicas, analisamos e propomos metodologias e processos de aprendizagem que os ajudem, a cada vez mais, se sentirem incluídos. O trabalho com as famílias já produziu algumas entrevistas, depoimentos gravados em vídeo, principalmente da família da Maria. A família do João ainda tenta se distanciar da instituição, mas futuramente pretendemos organizar alguns encontros para uma maior interação que traga possibilidades, para desenvolvermos um trabalho mais efetivo junto ao João. 


\section{CONCLUSÃO}

Todo o trabalho tem sido compartilhado com os professores e coordenação. Vale dizer que os alunos têm sido observados nos desempenhos: relacional e de aprendizagem. Tudo o que se consegue reunir é amplamente discutido pela comunidade acadêmica que tenta determinar quais os passos que precisam ser dados a seguir. Não contamos com modelos prontos que atendam aos nossos alunos, mesmo porque estes não existem, uma vez que as pessoas, com necessidades específicas ou não, são subjetivamente diferentes. Dessa forma, instituição, coordenação e professores vão construindo juntos melhores formas de ensino/aprendizagem.

A colaboração das famílias também é considerada como um aspecto importante. Tudo aquilo que puder ser oferecido por esta, pode facilitar o atendimento ao aluno.

Este processo tem contado com algumas dificuldades, considerando que em alguns momentos, foi possível sentir resistência das famílias, principalmente, quando os alunos apresentaram alguma dificuldade de aprender. Nestes, tentou-se convencer o núcleo familiar de que é preciso, com respeito à realidade individual, exigir do aluno, o máximo que ele possa oferecer. Afinal, trata-se de inclusão e essa pressupõe a chance de formar profissionais com mais possibilidades para o mercado, de acordo com o Decreto no 3298/99, que dispõe sobre a Política Nacional para a integração da pessoa portadora de deficiência no Brasil.

Acreditamos, firmemente, que vivemos um processo de construção que contará com muitos outros capítulos. Não abrimos mão de encontrar, em cada aluno, o que de melhor eles pode oferecer. Destacamos que a inclusão deve ser promovida a partir da experiência e do reconhecimento das diferenças, sejam elas de que ordem forem.

\section{REFERÊNCIAS}

[1] Ajuriaguerra, J.Manual de Psiquiatria Infantil. Rio de Janeiro: Ed. Atheneu, 1980.

[2] Brasil. Conselho Nacional de Educação. Câmara de Educação Básica. Resolução CNE/CEB n. 2, de 11 de setembro de 2001. Brasília: CNE/CEB, 2001.

[3] Brasil. Decreto 3.298/99 - Regulamenta a Lei $\mathrm{n}^{\circ} 7.8$ 53, de 24 de outubro de 1989, dispõe sobre a Política Nacional para a Integração da Pessoa Portadora de Deficiência, consolida as normas de proteção, e dá outras providências. Disponível em http://www.planalto.gov.br/ Acesso em: 18/02/2018.

[4] Figueira, E. Psicologia e inclusão: atuações psicológicas em pessoas com deficiência. Rio de Janeiro: Wak Editora, 2015.

[5] Nobrega, F. P. Compreender Hegel. Rio de Janeiro/ Petrópolis: Vozes, 2007.

[6] Olivier, L. de. Transtornos de comportamento e distúrbios de aprendizagem. Rio de Janeiro: Wak editora, 2013.

[7] Rangel (org.), Mary et Weshenfelder, Ignácio Lucio, fsc A didática a partir da pedagogia de La Salle. 3ª ed. Rio de Janeiro/Petrópolis: Vozes, 2010.

[8] Relvas, M. P. Neurociências e transtornos de aprendizagem: as múltiplas eficiências para uma educação inclusiva. Rio de Janeiro: Wak Editora, 2015.

[9] Vygotysk, L. S. A Formação Social da Mente. São Paulo: Martins Fontes, 1989. 


\section{Capítulo 10}

Implantação de políticas de ações afirmativas na PósGraduação do Instituto Federal do Espírito Santo

\section{Gabriel Domingos Carvalho \\ Renata Gandra de Melo}

Resu:mo: Em cumprimento à Portaria MEC №13/2016, o Instituto Federal do Espírito Santo (Ifes) regulamentou, em 2017, as ações afirmativas para inclusão de negros, indígenas e pessoas com deficiência nos cursos e programas de Pós-graduação. Foi instituída a Comissão Permanente de Ações Afirmativas na Pós-graduação do Ifes (CPAA-Pós) que elaborou documentos com recomendações relativas à reserva de vagas discentes e o acesso dos candidatos público-alvo dessas ações. Desde então, a CPPA-Pós tem acompanhado o trabalho da Diretoria de Pós-graduação na revisão de editais dos processos seletivos e a publicação destes no sítio institucional, com tradução para Libras, as adequações nos projetos pedagógicos e regulamentos de cursos, além de assessorar as coordenações de curso sempre que necessário. Do total de 720 vagas ofertadas em 21 processos seletivos, de 2017 a 2018, foram destinadas 180 vagas para candidatos negros ou indígenas e 44 vagas para candidatos com deficiência. Destas, 107 vagas foram efetivadas em matrículas de autodeclarados negros e 10 vagas foram efetivadas em matrículas de pessoas com deficiência: auditiva (4), física/motora (3) e visual (3). A implantação de políticas de ações afirmativas na pós-graduação do Ifes é um trabalho de planejamento conjunto e contínuo, que possibilita ampliar o acesso de negros, indígenas e pessoas com deficiência na Educação Profissional e Tecnológica gratuita e de qualidade, visando a permanência e êxito destes estudantes na nossa instituição.

Palavras-chave: Educação Profissional e Tecnológica; Institutos Federais; Ifes. 


\section{INTRODUÇÃO}

As ações afirmativas consistem em políticas públicas relacionadas a grupos discriminados e vitimados pela exclusão social ocorridos no passado ou no presente e voltadas à concretização do princípio constitucional da igualdade (Ribeiro et al., 2016). 0 objetivo destas ações é de eliminar as desigualdades e segregações de forma que não se mantenham grupos marginalizados e grupos elitizados na sociedade. As ações visam "combater não somente as manifestações flagrantes de discriminação, mas também a discriminação de fundo cultural, estrutural, enraizada na sociedade" (Ribeiro et al., 2016, p. 66).

Dentro desta perspectiva está a política de cotas implantada no ensino brasileiro. Um exemplo é a Lei no $12.711 / 2012$, que dispõe sobre o ingresso nas universidades federais e nas instituições federais de ensino técnico de nível médio, conhecida como Lei das Cotas, e vem sendo aplicada no Ifes desde a sua publicação, garantindo os percentuais de reservas previstos em cada modalidade de vaga dos processos seletivos para ingresso nos cursos de ensino médio técnico e graduação. Em 2016, a lei de cotas foi alterada pela Lei de no 13. 409 que incluiu a reserva de vagas para pessoas com deficiência nos cursos técnico de nível médio e de graduação das instituições federais de ensino.

Para a pós-graduação, diferentemente do que ocorreu para o ensino médio e graduação, não existe uma legislação federal que regulamenta a política de cotas de forma que devido à autonomia dos programas de pós-graduação, estas ações têm sido criadas de forma diferenciada e com características distintas pelas diferentes instituições de ensino superior (Venturini, 2017). Em 2016, o Ministério da Educação publicou a Portaria Normativa $\mathrm{N}^{\circ} 13$, que dispõe sobre a indução de Políticas de Ações Afirmativas voltadas para negros, indígenas e pessoas com deficiência na Pós-graduação. Tal portaria leva em consideração o que consta no Estatuto da Igualdade Racial, a constitucionalidade atribuída às ações afirmativas e a lei $12.711 / 2012$, que institui a reserva de vagas em cursos da graduação. Portaria Normativa MEC №13/2016 atribuiu às Instituições Federais de Ensino Superior a apresentação de propostas de inclusão, bem como a criação de comissões próprias com a finalidade de dedicarem-se e aperfeiçoarem destas políticas (Brasil, 2012; Brasil, 2016).

Segundo o Censo da Educação Superior de 2010, as estatísticas apontam que o ensino superior no Brasil passou por um considerável crescimento quantitativo a partir dos anos 90 , com taxa de expansão anual de $7 \%$ em média na graduação. Até então, as universidades públicas brasileiras eram um universo cujo acesso predominante era de estudantes oriundos de escolas privadas, de famílias com situação socioeconômica confortável e pais com elevado nível de escolaridade. Negros, indígenas e pessoas de baixa renda eram minoritários, estavam em cursos pouco valorizados e por isso eram conduzidos a espaços de pouco privilégio no mercado de trabalho, o que acentua ainda mais a desigualdade histórica. Nesse sentido, a Portaria Normativa $\mathrm{n}^{\circ} 13$ do MEC, compõem uma agenda de políticas públicas, cuja iniciativa direta está no enfrentamento dessas desigualdades existentes no país e remete ao papel social e político das universidades públicas brasileiras no atendimento ao direito à educação (Oliveira, Veiga e Carrano, 2016).

Anteriormente à Portaria Normativa ${ }^{\circ} 13 / \mathrm{MEC}$, alguns Programas de Pós-graduação já adotavam políticas próprias de inclusão para pretos, pardos e indígenas, partindo da autonomia de organização didáticoadministrativa conferida a estes. Essas iniciativas, que surgiram após demandas de programas específicos, culminaram na adoção de políticas mais abrangentes por algumas universidades públicas. No Rio de Janeiro, a Universidade Estadual do Rio de Janeiro (UERJ), por exemplo, é uma das que possui as mais antigas experiências de reserva de vagas para negros, indígenas e pessoas com deficiência considerando os Programas de Pós-graduação do país. A lei estadual n.6.914/2014 estabeleceu uma reserva de $20 \%$ das vagas ofertadas em cada curso e, em 2015 a lei foi alterada e passou a dispor da reserva de $30 \%$ em suas seleções. No âmbito das universidades públicas federais, a Universidade Federal de Goiás (UFG), por meio de resolução publicada em abril de 2015, passou a ser a primeira instituição pública federal do país a adotar ações afirmativas para a inclusão e a permanência da população negra e indígena em todos os seus cursos de pós-graduação stricto sensu (Oliveira, Veiga e Carrano, 2016).

\section{OBJETIVOS}

O objetivo deste relato é compartilhar a experiência e as ações desenvolvidas na implantação das políticas de ações afirmativas na pós-graduação do Instituto Federal de Educação, Ciência e Tecnologia do Espírito Santo, Instituto Federal do Espírito Santo (Ifes). Objetiva relatar como ocorreu a implantação bem como oferecer reflexões acerca dos desafios das ações afirmativas em cursos de pós-graduação nos Institutos Federais (IFs). 


\section{METODOLOGIA}

A experiência ocorreu no Ifes, no período de 2017 a 2018, e tem como sujeitos envolvidos os servidores gestores da pós-graduação no Instituto bem como os servidores que compõem a Comissão Permanente de Ações Afirmativas na Pós-graduação do Ifes (CPAA-Pós) instituída pela Resolução do Conselho Superior do Ifes № 10, de 27 de março de 2017.

A CPAA-Pós, foi designada pela Portaria da Reitoria do Ifes №1613, de 13 de julho de 2017, com mandato de três anos, e é composta por representantes dos cursos de Pós-graduação lato sensu e stricto sensu, do Fórum dos Núcleos de Estudos Afro-brasileiros e Indígenas (Foneabi), do Fórum dos Núcleos de Atendimento às Pessoas com Necessidades Específicas (Fonapne), do Fórum Interdisciplinar de Assistência Estudantil (Fiae), da comunidade científica para o quesito raça/cor e para o quesito deficiência, e, da Diretoria de Pós-Graduação da Pró-reitora de Pesquisa e Pós-graduação. Após sua implantação, a CPAA-Pós elaborou documentos de recomendações sobre as ações afirmativas relacionadas à formulação dos editais de processos seletivos para os cursos de Pós-graduação lato sensu e stricto sensu do Ifes bem como a verificação da autodeclararão dos candidatos cotistas aprovados nos mesmos de forma a garantir o acesso e a permanência dos sujeitos público-alvo das ações afirmativas.

\section{RESULTADOS}

Os Institutos Federais (IFs) foram criados, em 2008, pela Lei de no 11.892 e são instituições de educação fundamentadas na organização pedagógica verticalizada da educação básica à superior, pluricurriculares e multicampi, especializados na educação profissional e tecnológica, com base na conjugação de conhecimentos técnicos e tecnológicos às suas práticas pedagógicas visando a inovação a partir da relação entre ensino técnico e científico articulado com o trabalho, a ciência e a cultura sob a perspectiva da emancipação humana (Brasil, 2008; Escott e Ramos, 2016).

Segundo Pacheco (2011, p.14)

[...] a estrutura multicampi e a clara definição do território de abrangência das ações dos Institutos Federais afirmam, na missão das instituições, o compromisso de intervenção em suas regiões, identificando problemas e criando soluções técnicas e tecnológicas para o desenvolvimento sustentável com inclusão social.[...] o que se propõe é uma formação contextualizada, banhada de conhecimentos, princípios e valores que potencializam a ação humana na busca de caminhos de vida mais dignos.

Sobre este panorama se consolida o Instituto Federal de Educação, Ciência e Tecnologia do Espírito Santo ou Instituto Federal do Espírito Santo (Ifes), com a integração do Centro Federal de Educação Tecnológica (Cefetes) e as Escolas Agrotécnicas de Alegre (EAFA), Colatina (EAFC) e Santa Teresa (EAFST) de forma que as Unidades de Ensino do Cefetes (Vitória, Colatina, Serra, Cachoeiro de Itapemirim, São Mateus, Cariacica, Aracruz, Linhares e Nova Venécia) e as Escolas Agrotécnicas (Alegre, Santa Teresa e Colatina) passaram a formar sua estrutura multicampi. Posteriormente, foram implementados mais oito campi (Vila Velha, Guarapari, Ibatiba, Venda Nova do Imigrante, Piúma, Montanha, Barra de São Francisco, CentroSerrano) além de um campus avançado (Viana), um Polo de Inovação e um Centro de Referência em Formação e em Educação a Distância (Cefor).

Os cursos de educação profissional tecnológica ofertados pelo Instituto Federal do Espírito Santo, carregam uma importante missão de oportunizar a milhares de estudantes a possibilidade de obterem uma formação profissional, desempenhando, com isso, a função social de promover a qualificação para o trabalho, o pleno desenvolvimento e a preparação para o exercício da cidadania destes sujeitos (DOMINGOS et al., 2019). Desde 2011, o instituto, têm implementado políticas de inclusão, buscando fortalecer ações de educação especial numa perspectiva inclusiva. Em 2017 foram aprovadas resoluções do Conselho Superior, que instituíram as diretrizes operacionais e os procedimentos de identificação, acompanhamento para o atendimento aos alunos com necessidades específicas no âmbito institucional.

A Resolução do Conselho Superior do Ifes № 55, de 19 de dezembro de 2017, institui os procedimentos de identificação, acompanhamento e certificação de alunos com Necessidades Específicas no Ifes e assegura, dentre outros direitos, a realização de intervenções e adaptações quanto à acessibilidade e aprendizagem, adaptações curriculares de pequeno e grande portes, atendimentos como assistência estudantil, monitoria, atendimento educacional especializado e apoios complementares, incluindo área, profissionais, modalidade, local, frequência (IFES, 2017). 
A CPPA-Pós elaborou documentos com recomendações relativas à reserva de vagas e acesso dos candidatos público-alvo das ações afirmativas nos processos seletivos para os cursos de Pós-graduação do Ifes, em cumprimento à Portaria Normativa MEC №13/2016. No documento de orientação №01/2017 foi apresentado: a reserva de vagas que deve ser adotada nos editais dos processos seletivos, bem como suas modalidades e forma de ocupação; um modelo padrão de documento de autodeclaração para PPI; a adoção de mecanismos para inibir fraudes nos casos de candidatos autodeclarados; a exigência de informações referentes ao laudo médico e requerimento de condições especiais para prova dos candidatos com deficiência; a exigência da publicação do edital em Libras. Posteriormente, a Diretoria de Pós-Graduação elaborou uma minuta de edital de processo seletivo, no qual constam as orientações e documentos propostos pela CPAA-Pós, em atendimento aos documentos elaborados.

As recomendações da CPPA-Pós sobre para a adoção de mecanismos para inibir a fraude nos casos de candidatos autodeclarados passou por análise da Procuradoria Federal do Ifes, em setembro de 2017, recebendo parecer favorável. Esta procuradoria recomendou a instalação de uma Comissão Especial para as denúncias de fraudes em autodeclarações, devendo esta comissão ser criada previamente e com um prazo de exercício definido, de maneira a tornar mais célere os procedimentos de análise das possíveis situações concretas que, porventura, possam ocorrer. No que tange os candidatos com deficiência, caso exista dúvida sobre a deficiência declarada pelo candidato, foi recomendado que a questão seja encaminhada para análise e parecer de um médico do Instituto. Este modelo adotado pelo Ifes acerca da presunção, reconhece a autodeclaração de forma relativa, pois ela poderá ser reavaliada por uma Comissão Especial, em casos de suspeita.

Em 2018, foi instituída no Ifes uma Comissão Institucional responsável pela elaboração do documento base dos critérios de verificação da veracidade na autodeclaração nos processos seletivo para discentes (Portaria do Reitor № 313, de 16 de fevereiro de 2018), composta por representantes de todas as Próreitorias do Ifes, inclusive de Pesquisa e Pós-graduação (Prppg) e CPAA-Pós. Esta Comissão, no intuito de validar o documento que estabelece e regulamenta os procedimentos e os critérios da verificação da veracidade da autodeclaração, buscou uma aproximação com a sociedade civil organizada, dando voz aos sujeitos de direito que farão uso das ações afirmativas no Ifes. Dessa forma, foram realizadas articulações junto ao Núcleo de Estudos Afro-Brasileiros e Indígenas (Neabi) para realização de encontros com lideranças indígenas regionais, com o Movimento Negro do Espírito Santo e com o Centro de Estudos da Cultura Negra do Espírito Santo. O documento foi apresentado e tais representações tiveram a oportunidade de tirar suas dúvidas, sugerir alterações e colaborar na construção do mesmo.

A partir da instituição da CPAA-Pós e da elaboração pela mesma do documento de orientações para processos seletivos discente da pós-graduação em outubro de 2017, todos os editais dos processos seletivos para os cursos de Pós-graduação lato sensu e stricto sensu passaram a contemplar a reserva de vagas para o público negro (pretos e pardos), indígenas e deficientes. A Comissão tem acompanhado o trabalho da Diretoria de Pós-graduação na revisão de editais dos processos seletivos, publicação destes no sítio institucional com tradução em Libras, adequações nos projetos pedagógicos e regulamentos de curso, além de assessorar as coordenações de curso sempre que necessário. Dos 15 cursos de Pós-graduação ofertados em 2018, em diferentes áreas de concentração, foram ofertadas um total de 627 vagas, sendo 427 para ampla concorrência (AC), 161 para reserva de vagas para pretos, pardos e indígenas (PPI), 39 para reserva de vagas para pessoas com deficiência (PcD). Após os processos seletivos, foram efetuadas 84 matrículas de reserva de vagas, sendo 76 estudantes PPIs e 08 PcDs.

\section{CONSIDERAÇÕES FINAIS}

Considerando todos os aspectos que gerenciam a criação e a implantação do Ifes, não se pode negar a defesa da inclusão social, na esfera da educação profissional e tecnológica, como possibilidade para qualificação profissional e como uma forma de garantia da educação como direito social de todos.

A criação e implantação de uma política de ações afirmativas na Pós-graduação do Ifes possibilitou ampliar o ingresso de pessoas negras, indígenas e com deficiência, bem como garantir a permanência qualificada desses estudantes na instituição, assegurando os seus direitos, assim como fortalecer linhas e grupos de pesquisas voltados para a sustentabilidade sociocultural, territorial, educacional, científica e tecnológica dos povos indígenas, da população afro-brasileira e das pessoas com deficiência. 


\section{REFERÊNCIAS}

[1] Brasil. Lei $n^{\circ}$ 11.892, de 29 de dezembro de 2008. Institui a Rede Federal de Educação Profissional, Científica e Tecnológica, cria os Institutos Federais de Educação, Ciência e Tecnologia, e dá outras providências. Brasília, 2008.

[2] Brasil. Lei $\mathrm{n}^{\circ}$ 12.711, de 29 de agosto de 2012. Dispõe sobre o ingresso nas universidades federais e nas instituições federais de ensino técnico de nível médio e dá outras providências. Brasília, 2012.

[3] Brasil. Ministério da Educação. Portaria Normativa n 13, de 11 de maio de 2016 - Dispõe sobre a indução de Ações Afirmativas na Pós-Graduação, e dá outras providências. DOU - Diário Oficial da União, Brasília, № 90, 12 de maio de 2016.

[4] Domingos, Leonardo Nunes et al. Educação Profissional Técnica Integrada ao Ensino Médio: que aluno(a) queremos formar? Proensino $\mathrm{n}^{\circ}$ 1, Vitória, 2019. Disponível em: <https://proen.ifes.edu.br/images/stories/Texto_Proensino_N_01.pdf>. Acesso em: 10 de abril de 2019.

[5] Escott, C. M.; Ramos, V. S. Contexto atual: IFRS como instituição inclusiva. In: Sonza, A. P.; Salton, B. P.; Strapazzon, J. A.; Lázaro, A.(orgs). Coleção Estudos Afirmativos 7 - Ações afirmativas: a trajetória do IFRS como instituição inclusiva. Rio de Janeiro: Flacso, GEA, UERJ, LPP, Capítulo 1, p. 13-20, 2016.

[6] IFES - Instituto Federal do Espírito Santo. Resolução do Conselho Superior №10 de 27 de março de 2017 Regulamenta a adoção de ações afirmativas nos cursos e Programas de Pós-graduação do Ifes, com foco na inclusão de negros (pretos e pardos), indígenas e pessoas com deficiência. Disponível em: <https://prppg.ifes.edu.br/comissao?showall=\&start=2>. Acesso em: 10 de abril de 2019.

[7] IFES. Instituto Federal do Espírito Santo. Resolução do Conselho Superior №55 de 19 de dezembro de 2017 Institui Procedimentos de Identificação, Acompanhamento dos Alunos Necessidades Específicas no Ifes - Alterada pela Resolução CS №19/2018. Disponível em: <https://ifes.edu.br/conselhos-comissoes/conselhosuperior?showall=\&start=10>. Acesso em: 10 de abril de 2019.

[8] IFES. Instituto Federal do Espírito Santo. Portaria do Reitor № 1613, de 13 de julho de 2017 - Composição da Comissão Permanente de Ações Afirmativas dos Programas de Pós-Graduação do Ifes. Disponível em: <https://prppg.ifes.edu.br/comissao?showall=\&start=2>. Acesso em: 10 de abril de 2019.

[9] IFES. Instituto Federal do Espírito Santo. Portaria do Reitor № 313, de 16 de fevereiro de 2018 - Composição da Comissão Institucional responsável pela elaboração do documento base dos critérios de verificação da veracidade na autodeclararão nos processos seletivos para discentes. Disponível em: <https://prppg.ifes.edu.br/comissao?showall=\&start=2>. Acesso em: 10 de abril de 2019.

[10] Oliveira, Amanda de; Veiga, João Marcos; Carrano, Paulo. Ações Afirmativas nos Programas de PósGraduação: experiências, a nova portaria do MEC e seus desdobramentos. Anped - Associação Nacional de PósGraduação e Pesquisa em Educação, 29 de julho de 2016. Disponível em: <http://www.anped.org.br/news/acoesafirmativas-nos-programas-de-pos-graduacao-experiencias-nova-portaria-do-mec-e-seus $>$. Acesso em: $10 \mathrm{de}$ abril de 2019.

[11] Pacheco, E. Institutos Federais: uma revolução na educação profissional e tecnológica. In: Pacheco, E. (org). Institutos Federais: uma revolução na educação profissional e tecnológica. Brasília, São Paulo: Editora Moderna, 2011.

[12] Ribeiro, S. M.; Almeida, M. T. C.; Maia, F. A.; Souza, F. A. Amaral, D. P. O.; Alves, M. R. Política de cotas no ensino superior: percepções de professores e estudantes. Revista Unimontes Científica, v. 18, n.1, p. 64-72, 2016.

[13] Venturini, A. N. Ações afirmativas para a pós-graduação: desenho e desafio de política pública. Anais do 41ํㅡ Encontro Anual da Associação Nacional de Pós-Graduação e Pesquisa em Ciências Sociais. Caxambu, 2017. Disponível em https://anpocs.com/index.php/papers-40-encontro-2/spg-4/spg27-1/11080-acoes-afirmativas-para-posgraduacao-desenho-e-desafios-da-politica-publica-1/file. Acesso em 20/04/2019. 


\section{Capítulo 11}

Educação especial: Inclusão Social e promoção de medidas de conscientização e combate à violência escolar

\section{Fernanda Lima Ferreira \\ Dulce Barbosa Lins \\ Larissa Kelly dos Santos Silva \\ Ozinaldo Oliveira dos Santos}

Resumo: A educação inclusiva é um tema muito pertinente nas áreas de pesquisa da educação. Com o avanço deste tema, as escolas foram se adaptando a receber alunos com necessidades especiais e que precisem de mais atenção na sala de aula. No entanto essa convivência escolar sem o acompanhamento correto, pode vir a gerar o tão comentado bullying. Essa pesquisa tem por objetivo investigar e apurar a incidência de bullying nas escolas, além de realizar um projeto de conscientização da escola e dos próprios alunos, e analisar a preparação das escolas para a recepção destes alunos. A escola foi visitada na manhã do dia 25/03/2019, crianças de 10 a 12 anos foram avaliadas, foi passado um questionário simples com perguntas especificas de "sim" ou "não" afim de verificar se eles tinham ciência do que é o bullying e se já tinha presenciado alguma situação desagradável na escola. Os resultados obtidos nesse questionaram mostraram que $45,83 \%$ das crianças já presenciaram algum caso de bullying, 20,08\% nunca presenciaram e 33,3\% não tem certeza, além disso outros dados como quantas crianças com deficiências eles conheciam também foram analisados. Esta pesquisa se torna importante a partir do momento em que é perceptível o número baixo de mátriculas no ensino regular de crianças com deficiência que pode ser associado ao bullying e a professores despreparados em sala de aula.

Palavras-chave: educação especial, bullying, educação regular, inclusão. 


\section{INTRODUÇÃO}

A luta pela inclusão e aceitação de pessoas com deficiência na sociedade tem início por volta do século XVIII, onde essas pessoas eram vistas como redentoras de alma e podiam frequentar, ou morar, em lugares especializados, como orfanatos e manicômios, onde podiam ser tratados e ensinados para desenvolver algumas habilidades, mas o marco da inclusão das pessoas com algum grau de deficiência ou algum tipo de transtorno no meio acadêmico foi por volta dos séculos XIX e XX onde teve a criação das primeiras escolas especiais, que tinham a visão de integrar essas pessoas a comunidade ao seu redor, mas não com o objetivo de igualar ao restante da sociedade. A partir de então estudos em várias áreas, como da saúde, educação e psicologia provaram que pessoas com deficiências e com transtornos globais eram capazes de aprender e se desenvolver no meio social.

A maior referência da conquista de espaço dessas pessoas para igualdade na sociedade foram as leis criadas para garantir seus direitos por toda vida acadêmica, garantindo uma qualificação para o meio de trabalho desejado e vida em sociedade. A partir da constituição federal de 1988 e da LDBEN (lei de diretrizes e bases da educação nacional) de 1996 , afirmando que educação de qualidade é direito de todos e dever do estado e da família, se é direito de todos, pessoas que tem alguma deficiência ou transtorno podem e devem ser educados em sociedade, respeitando suas diferenças e limitações, A LDBEN promove e deixa claro a inclusão da educação especial em institutos de ensino regulares criando assim a modalidade de educação especial oferecida em escolas regulares, com medidas que auxiliam alunos dessa modalidade em questões desde acessibilidade e locomoção, acompanhamento especializado para desenvolvimento das suas habilidades cognitivas até leis sobre criações de estratégias educacionais para melhor atender o público escolar, como medidas de prevenção a intimidação sistemática (bullying). 0 ministério da Educação aprovou, a partir de 2015, a sala de recursos multifuncionais, onde alunos com necessidades físicas ou mentais terão atendimento educacional especializado, seu funcionamento é oposto aos horários de aula. onde os alunos da modalidade poderão desenvolver em tempo regular as matérias padrões do ensino, e em horário oposto das aulas eles poderão desenvolver suas habilidades cognitivas e motoras diminuindo suas limitações.

Dentro das escolas ainda existe um hábito entre os alunos de promover e aplicar a intimidação, podendo passar despercebida pela área pedagógica da instituição e não ter as devidas medidas tomadas para sua solução, causando problemas para quem sofre a intimidação, como exemplo de afastamento social e depressão. Com a implantação da educação especial em escolas regulares, é percebido uma vulnerabilidade desses alunos no âmbito escolar, além da falta de uma boa infraestrutura para a locomoção dos mesmos, muitos sofrem com problemas de interações com os demais colegas e com o bullying, com isso focaremos em reconhecer essas vulnerabilidades nas dependências escolares para reportar a coordenação da escola e focar na prevenção do preconceito e bullying. Trabalhando através de conversas e dinâmicas a inclusão e interação entre os alunos reforçando a formação de valores e respeito, e a promoção de medidas de conscientização e combate à violência escolar, visando a conscientização dentro das salas de aula acerca do tema.

\section{METODOLOGIA}

A parte inicial do trabalho se deu a partir da leitura de artigos, teses e documentos que se tratam dos temas propostos. Documentos como a LDB (Lei de Diretrizes e Bases da Educação) e o PNE (Plano Nacional da Educação) foram usados como bases para a escrita do projetos e elaboração do mesmo, afim de entender mais o tema e o que deve ser esperado segundo a lei, desta maneira, poderia ser feito uma comparação como que é pedido no papel e o que se encontra da pratica do dia a dia das escolas. A leitura de artigos teses foi essencial para a base sociológica afim de entender como o deficiente é visto no meio escolar e na sociedade, desta maneira poderíamos compreender melhor a visão dos profissionais que lidam com essas situações, dos alunos que estão em contato com eles e do próprio deficiente que vivencia essa experiencia social.

Os dados recolhidos na pesquisa também tiveram fontes de sites fornecidos por órgãos do governo como o número de matrículas de deficientes nas escolas do estado de Alagoas e no Brasil e a quantidade de escolas disponíveis na região. A elaboração dos questionários foi feita baseada em uma tese, sofrendo algumas modificações. Tendo em vista que trabalharíamos com crianças de até 12 anos. Além da aplicação de questionários para as crianças, também tiveram momentos com os professores, onde eles explicaram a forma que conduzem a situação de uma turma que contém um deficiente. Foi conversado com a professora de educação física e a psicopedagoga que é responsável pela sala de recursos da escola. Desta maneira foi possível observar métodos e esquemas utilizados na prática da sala de aula. 


\section{DESENVOLVIMENTO}

A inclusão escolar, vem crescendo nas últimas décadas, desenvolvendo um movimento completo que tem a base a luta social das pessoas com deficiência e seus familiares para ter seus direitos básicos de desenvolvimento incluso na sociedade. A partir de 1970 começa se ter uma nova visão sobre a deficiência em meio a sociedade em contraposição ao que se acreditava historicamente ser o certo, essa visão vem alinhada com uma nova perspectiva social, mais abrangente e sistêmica (Secretaria municipal de educação, 2016) nessa nova perspectiva não se nega que pessoas com deficiências tenham suas limitações e precisem de atendimentos especializados, mas enfoca que a pessoa com algum tipo de transtorno não deve ser apenas integrada em volta da sociedade onde só enxergam suas limitações, ao invés de se ter uma verdadeira inclusão onde o deficiente consiga se desenvolver plenamente em seu dia a dia.

A escola historicamente se caracterizou pela visão da educação que delimita a escolarização como privilégio de um grupo, uma exclusão que foi legitimada nas políticas e práticas educacionais reprodutoras da ordem social. A partir do processo de democratização da escola, evidencia-se o paradoxo inclusão e exclusão quando os sistemas de ensino universalizam o acesso, mas continuam excluindo indivíduos e grupos considerados fora dos padrões homogeneizadores da escola. (MEC/SEESP, 2007) Com a nova visão global sobre as pessoas com deficiência leis tiveram que ser criadas para garantir seus direitos, perante a vida escolar para essas pessoas o Brasil deu um grande passo ao incluir e destacar em sua constituição e em leis federais e estaduais a educação especial como prioridade, direito e dever do estado e sociedade de cumpre-las. Na Própria LDBEN (Leis de diretrizes e bases da educação nacional) é garantido o direito de a educação especial ser inclusa em ensino regular com total inclusão do aluno nas atividades curriculares e sociais no meio escolar. A educação especial afirma também que qualquer aluno com necessidades físicas ou mentais, tem direito a atendimento educacional especializado e gratuito, com isso foi criado o projeto pelo ministério da educação onde está sendo implementadas nas escolas a sala de recursos multifuncionais para ajudar os alunos e professores na adaptação e convivência no dia a dia. Em Alagoas cerca de $50 \%$ a $69 \%$ das escolas já tem esse recurso. (fonte: MEC/secadi,2015). A partir de então as matriculas nessa modalidade em escolas regulares teve um aumento significativo, $82 \%$ dos alunos de 4 a 17 anos com deficiência, transtornos globais do desenvolvimento ou altas habilidades foram incluídos em classes comuns (senso escolar, 2016).

Com os avanços políticos sobre a inclusão nas escolas, novos desafios apareceram, com o aumento no fluxo de matriculas da modalidade especial, as escolas se viram despreparadas para atender esses novos alunos, tanto em infraestrutura e equipamentos como por falta de profissionais especializados para ajudar a esses alunos, um bom exemplo sobre a falta de preparação em escolas da rede pública para atender os alunos da educação especial, é que até 2016 os banheiros adequados a alunos com deficiência ou mobilidade reduzida estava disponível apenas em 33\% das escolas de anos iniciais, em $48 \%$ daquelas que oferecem os anos finais e em $58 \%$ nas de ensino médio (senso escolar, 2016). Onde se foi feita a pesquisa mesmo tendo uma boa mobilidade com rampas e corrimãos dentro da escola, para as pessoas com deficiências visuais não era oferecido o piso tátil para locomoção do aluno e não tinha equipamentos adequados para pratica esportiva inclusa, isso são apenas exemplos de como as escolas brasileiras não estão aptas para receber esses alunos. Uma grande dificuldade também relatada em grande parte das escolas brasileiras, é a violência escolar. A cultura do bullying tem ganhado força em ambiente escolar, e ao incluir a modalidade especial nas escolas regulares, os alunos ficaram vulneráveis, por falta de clareza e até de conscientização dos profissionais da educação, a um meio de práticas ofensivas, por parte dos outros alunos, que os ferissem emocionalmente. Isso mostra que mesmo com um aumento de $82 \%$ de matriculas desses alunos, por conta de dificuldades em sua mobilidade e acessibilidade a escola, e por não ter uma boa convivência social escolar, a frequência em sala de aula desses alunos acaba diminuindo, afetando seu desenvolvimento. Iniciativas de conscientização e prevenção ao bullying tem que estar sempre presente nas escolas, dinâmicas em sala de aulas e atividades que consigam incluir a todos é essencial para se criar um ambiente social igualitário onde pregue-se o respeito. A função da escola é de propiciar conteúdos e valores pautados na ética, que possui como elementos constitutivos o respeito mútuo, a justiça, o diálogo, a solidariedade, a cooperação, a sinceridade e a autenticidade (Rev. EF, 2010) e não de virar um ambiente onde alunos se sintam ameaçados e prefiram se afastar.

\section{RESULTADOS E DISCUSSÕES}

A escola foi visitada durante a manhã do dia 25/03/2019, o total de crianças entrevistadas foi de 24 , onde se obteve os seguintes resultados baseados no questionário aplicado: $70,8 \%$ das crianças conhecem alguma outra criança que esteja em idade escolar (5 - 17 anos) e tenha deficiência, 29,16\% não conhecem 
ninguém nesta situação nessa idade. Em relação ao bullying as crianças também informaram que 45,83\% já presenciaram algum caso de bullying, 20,8\% nunca presenciaram um caso de bullying e 33,3\% não tem certeza se já presenciaram algum caso de bullying. Além das pesquisa com as crianças foram entrevistados professores e profissionais da escola.

A coordenação passou alguns dados importantes à partir do inicio da introdução da educação especial na escola, como a iniciativa de convidar os pais para se conscientizar e passar a perceber sinais de que seu filhos possa ter traços que necessitem de acompanhamentos especializados. Um bom exemplo da escola sobre inclusão é a aula de educação fisica, onde a professora faz dinamicas que pregam a aceitação e o trabalho em grupo, no entanto a mesma informou que a maior dificuldade da escola é a grande quantidade de alunos por turma e a falta de equipamentos necessarios para trabalhar com esses alunos. Um comentario feito pela professora foi que em sua pratica esportiva ela nao presencia atos de desrespeito e bullying com frequencia, pelo contrario, os alunos se ajudam e a aula consegue fluir bem.

Além disso a escola oferece de recursos, onde tem atendimento duas vezes por semana, 1hr por dia, no periodo contrario a aula com acompanhamento de um profissional. Sobre essa sala foi conversado com a psicopedagoga responsável que deu as seguintes informações: quando ela foi encaminhada para o colégio em questão a sala estava fechada e ela teria recebido o desafio de reativa-la, em um ano ela conseguiu o apoio da coordenação e a presença ativa dos pais. Ela atende em torno de 10 crianças com diversas necessidades, entre elas cegos, surdos, transtornos mentais e autismo.

Outra coisa que também foi observada foi a adaptação da escola em relação as necessidades que alunos com deficiência, seja ela motora ou visual por exemplo, necessitam. A escola era bem adaptada para pessoas com deficiências motora, os banheiros eram amplo e tinham um banheiro em especial para cadeirantes. As salas eram bem adaptadas com rampas nas entradas para o acesso dos alunos, o refeitório tinha duas entradas, uma não necessitava de rampa, mas tinha a porta bem larga, a outra tinha a rampa de acesso. Locais como a entrada da escola, acesso ao pátio/ginásio e a área de educação infantil também tinham acesso facilitado. No entanto a escola não era bem adaptada aos deficientes visuais pois não tinham, por exemplo, pisos táteis para a melhor locomoção e orientação do aluno dentro da escola.

Os estudos realizados nessa área no estado de Alagoas apontam que as matrículas na modalidade da educação especial ainda estão baixas comparadas em geral. De 2017 para 2018 houve uma queda 27,07\% em média nas matrículas dos alunos da educação especial, esses dados estão disponíveis em sites do próprio governo. Esses números se dão devido a fatores como bullying, despreparo da escola e dos profissionais para recebê-los e até mesmo a falta de apoio dos pais.

Hoje o bullying se manifesta como espelho da falta de informação da escola para com os alunos e do despreparo dos pais para tratar isso dentro de casa, gerando problemas como a diminuição da frequência de alunos especiais na educação regular. Os estudantes com deficiência acabam se afastando da escola por não se sentirem seguros e a vontade no local escolar, gerando problemas maiores como dificuldade de socialização e isolamento daquele educando, podendo ocasionar problemas futuros na vida pessoal, acadêmica e profissional. Para incluir esses alunos na educação regular, as escolas têm que se adaptar não somente na estrutura física, mas sim no acolhimento e na conscientização da inclusão de alunos especiais nas atividades escolares.

A inclusão escolar deve ser praticada não só por alunos, mas também por professores, sabendo que a escola é obrigada por lei a aceitar os alunos especiais, se privadas, não cobrarem nenhum valor adicional por causa da condição do aluno. É uma realidade saber que nem todos os professores estão capacitados para receber e acolher alunos com necessidades variadas, isso dificulta uma boa adaptação do aluno em sala de aula. Esse tipo de pesquisa se torna importante a partir do momento que se tem o dever de acolher e alertar a aqueles que não acolhem, gerando uma sociedade sadia e de boa vivência para todos, não só para quem está no padrão.

\section{CONSIDERAÇÕES FINAIS}

Com esse projeto visamos a disseminação do respeito diante das individualidades dos indivíduos, reforçar a formação de valores nos estudantes e salientar o direito das pessoas inclusas na modalidade da educação especial. Além de observar e analisar a orientação que os professores têm para lidar com essas situações especificas. Esperamos deixar resultados de uma escola integradora e inclusiva, aberta a diversidade. E ainda analisar como a escola lida como um todo com essa situação, como está se adaptando e como reage a determinados momentos com essas crianças. Ser uma criança especial é ser uma criança diferente, e essa diferença está também no professor atuante na área, ou seja, fazer e ser a diferença. 


\section{REFERENNCIAS}

[1] Barros, P; Carvalho, J; Pereira, M. Um estudo sobre o bullying no contexto escolar. [S. I], 2009

[2] Brasil, Lei de diretrizes e bases da educação. 1996

[3] Brasil, Plano Nacional de Educação. 2014

[4] Casagrade, Ferdinando. A legislação educacional que trata da inclusão. Disponível em<https://novaescola.org.br/conteudo/1723/a-legislacao-educacional-que-trata-dainclusao?gclid=cjwkcaia45njbrbweiwasnzt5xuzqnck7q2c2proqvmtqv35cgglpavc4hsls7qtcjluf8eq47dj1roc_goqavd_b we> acesso em:13 de fev. de 2019

[5] Censo escolar 2016. Brasília, fevereiro de 2017, p. 15 e 16

[6] Combate ao bullying nas escolas. Revista EF - ano IX n.38- dezembro de 2010

[7] Dias, F; Pingoello, I. Bullying na educação inclusiva. [S. I], julho de 2016

[8] Franco, Simone. Lei Brasileira de Inclusão entra em vigor e beneficia 45 milhões de pessoas. Disponível em< https://www12.senado.leg.br/noticias/materias/2016/01/21/lei-brasileira-de-inclusao-entra-em-vigor-e-beneficia45-milhoes-de-brasileiros> acesso em: 13 de fev. de 2019

[9] Guia de educação especial para a inclusão na rede municipal de ensino de Maceió. Maceió: Viva Editora. 2016, p. 24 a 31

[10] Maia, Miranda. Um diagnóstico sobre a educação inclusiva: organização escolar, concepções de professores e desafios. 2014. 73f. Trabalho de conclusão de curso- Universidade Federal de Paraíba, João Pessoa, 2014

[11] Mec/Seesp. Política Nacional de Educação Especial na Perspectiva da Educação Inclusiva. 09 de outubro de 2007

[12] Mendanha, Soraya. Com avanços na educação, Lei Brasileira de Inclusão completa um ano. Disponível em <https://www12.senado.leg.br/noticias/materias/2016/07/05/com-avancos-na-educacao-lei-brasileira-de-inclusaocompleta-um-ano> acesso em 14 de fev. de 2019

[13] Menezes, Ebenezer. Necessidades educacionais especiais. Disponível em<http://www.educabrasil.com.br/necessidades-educacionais-especiais/> acessado em 14 de fev. de 2019

[14] Miranda, Fabiana. Educação especial em uma perspectiva inclusiva: Aspectos históricos. Revista educação especial em debate [online] - v. 2 n.04- dezembro de 2017

[15] Planalto. Constituição da república federativa do Brasil. 1988.

[16] Santos, A.; Kassar, M. Escolarização dos alunos da educação especial na política de educação inclusiva no Brasil. Alcalá-ES. 2018

[17] Zavareze, Taís. A construção histórico cultural da deficiência e as dificuldades atuais na promoção da inclusão. Santa Catarina. 2009 


\section{Capitulo 12}

\section{Relato de experiência: Intervenções de uma educadora física com jovem com paralisia cerebral}

\section{Priscila Figueiredo Brito de Azevedo \\ Francisca Maria Gomes Cabral Soares \\ Jordana Lorena Nogueira de Sousa}

Resumo: Este trabalho tem o objetivo de apresentar um relato de experiência sobre as intervenções de uma educadora física com um jovem com Paralisia Cerebral (PC), desenvolvida em uma instituição de performance na cidade de Mossoró-RN. Apresentaremos brevemente algumas informações acerca da paralisia cerebral e o que os estudos/pesquisas teóricos dizem, bem como, o percurso realizado em busca de estratégias de adaptação, estímulo sensorial e inclusivo, respeitando sempre os limites do aluno (motor e psicológico). Este estudo torna-se pertinente para a comunidade acadêmica, no sentido de abrir um leque de possibilidades e informações sobre como lidar com sujeitos com PC. Os resultados obtidos sinalizam melhorias significativas e superações dos obstáculos e ainda, a importância da Educação Física na socialização, autoestima e no desenvolvimento.

Palavras-chave: Ensino aprendizagem, desafios,TDAH, comportamento. 


\section{CONSIDERAÇÕES INCIAIS}

A Paralisia Cerebral é um distúrbio permanente, embora não variável do movimento e da postura, devido a efeito ou lesão não progressiva do cérebro no início da vida (Leite \& Prado, 2004). A Paralisia Cerebral pode ser classifica segundo dois critérios: pelo tipo de disfunção motora presente, que inclui os tipos atetóide, atáxico, misto e espático e pela topografia dos prejuízos, ou seja a localização do corpo afetado, que inclui tetraplegia ou quadriplegia, monoplegia, paraplegia, diplegia e triplegia (Ferrareto\&Sousa, 1998).

De acordo com Colledge (1999) dependendo da área de lesão do cérebro pode ocorrer alguns dos seguintes sintomas: rigidez muscular ou espasmos, persistência dos reflexos primitivos, dificuldades nas habilidades motoras grossas (como maninhar e correr, dificuldade na coordenação motora fina (como escrever e falar), sensações e percepções anormais. Essas alterações neuromotoras podem comprometer o desempenho funcional, ou seja, as tarefas do dia-a-dia, como por exemplo tomar banho e vestir-se.

Segundo Stainback\&Stainback (1990), a inclusão é uma consciência de comunidade, uma aceitação das diferenças e uma corresponsabilização para obviar ás necessidades de outros., com a ideia de incluir apenas as pessoas com deficiência em um determinado grupo /social e ou educacional.

É importante compreender que o processo de inclusão está vinculado a todos os âmbitos da sociedade, tais como, educação, esporte, lazer, religião, família, etc., e a todos os participantes da sociedade. independentemente de sua condição física, intelectual, sensorial, cultural, social ou econômica

0 número de pessoas portadoras de deficiência com um estilo de vida sedentário continua a ser considerável e a crescer (Zucheto \& Castro, 2002). A prática da atividade física tem um papel fundamental no desenvolvimento dos estilos de vida saudáveis e benéficos, promovendo a saúde e contribuindo para a prevenção de doenças. Para tal, o exercício deve ser realizado regularmente permitindo manter uma forma de vida independente e a superação dos problemas na realização das tarefas do quotidiano (Llano, Manz, \& Oliveira, 2004), funcionando assim como um modo de compensação ao decréscimo das habilidades funcionais nas pessoas com Paralisia Cerebral (Gallahue et al., 2003).

De acordo com Schwartzman (2004), todo o processo de reabilitação a que estas crianças e jovens são submetidas deve revestir-se de um carácter multidisciplinar.

0 relato de experiencia que apresentaremos a seguir traz a caminhada de um jovem portador de paralisia cerebral do qual superou os obstáculos da vida para alcançar seu único sonho: correr. Esse relato vem acompanho do depoimento da mãe do jovem

DESENVOLVIMENTO

\section{RELATO DA MÃE}

Meu filho nasceu em 23/07/1997 em Mossoró, aos 8 meses de gestação da mãe, prematuro, permaneceu na incubadora por 10 dias e foi vitima de uma parada cardiorrespiratória, possuía muito edema e em seu exame do pezinho foi diagnosticado com Hiperplasia Suprarrenal, uma doença congênita, além da Paralisia Cerebral ele teve Atáxia (perda do controle muscular durante movimentos voluntários), buscamos tratamento em cidades como Curitiba e Porto Alegre para realização de uma averiguação genética. Utilizamos um tratamento com Botox devido o encurtamento dos tendões para alongamento dos nervos, incialmente obtivemos bons resultados, cada aplicação tinha uma durabilidade de 6 meses, após a sétima aplicação a evolução não começou a ser mesma regredindo ainda mais.

Sua primeira cirurgia tendão e coxas foi aos 3 anos de idade, aos 4 anos ele passou novamente por mais duas cirurgias, aos 5 anos foram três cirurgias, sendo aos 7 anos de idade um dos maiores procedimentos já realizados sendo necessário utilização de gesso até a região umbilical, aos 8 anos de idade fez a cirurgia para correção das coxas pois elas estavam entrando para dentro .

Meu filho aos 3 anos de idade não andava, não tinha equilíbrio, pisava nas pontas dos pés, fazendo uso de tala e aparelhos, um deles segurava o corpo dele em pé e possuía uma trava no joelho, foi assim que nessa idade ele foi melhorando um pouco o equilíbrio para tentar uma melhor qualidade de vida. Uma das consequências foi a baixa visão, imaginávamos que esse fato se dava a algum problema de ordem de visão, mas em Porto Alegre se teve o diagnóstico de ordem neurológica

Na escola a rotina dele tentava se encaixar com sua realidade de vida, nas aulas de Educação Física ele era dispensado, não possuindo durante o período escolar uma vivência com a atividade desportiva. Foi nessa fase que nos deparamos com mais um ocorrido, uma queda, com fratura exposta em um braço precisando passar por 3 cirurgias de correção.

Meu filho ainda teve convulsões e epilepsias fazendo uso de vários remédios dentre eles antidepressivos 


\subsection{RELATO DO PAI}

Todos os dias meu filho estava na janela do seu quarto, olhando para um horizonte que eu não conseguia entender mais qual era, eu chorava no meu silêncio e me perguntava o que eu poderia fazer para retirar a tristeza daquele seu olhar

\subsection{RELATO PROFISSIONAL}

A mãe do jovem entrou em contato comigo por telefone agendando um horário para que pudéssemos conversar, incialmente mesmo de forma distante senti a aflição da mãe e ao mesmo tempo o desafio que estava bem na minha frente. Trabalhando com atividade física para performance nunca imaginei que depararia com algo que marcasse e me instigasse a poder fazer mais e mais por aquele jovem e sua família. No dia em que o conheci, percebi algumas características específicas dele, o uso constante de um boné, o olhar que não se direcionava a nossa fala, um alguém muito distante daquela realidade aos seus olhos não aos meus. Fui informada das condições físicas e cognitivas dele através de laudos médicos e a autorização dos mesmos para iniciarmos, então, em nosso primeiro contato perguntei qual era o seu sonho: ele me respondeu correr, mas ao mesmo tempo já colocou em sua fala o peso da negatividade de que nunca conseguiria, então, iniciamos os trabalhos em solo, inicialmente toda a parte de condicionamento físico se deu em solo com exercícios de rastejar, puxar, empurrar, de uma forma que pudesse obter melhoria da sua capacidade energética para desenvolvimentos de habilidade físicas, após 3 meses, iniciamos lentamente movimento de caminhar em esteira em velocidade muito baixa, logo começamos a nos deparar com dores na região da panturrilha o que aparentemente devido a realidade dele é extremamente normal, aumentamos a frequência semanal para que pudéssemos realizar o protocolo de prescrição de treinamento pois ele necessitava de um tempo maior para realização das suas tarefas. Aos poucos as caminhadas se tornaram trotes, até que conseguimos inserir neles atividades de fortalecimento de CORE com Levantamento de Peso Olímpico, com o aumenta da massa magra e diminuição da gordura corporal conseguimos completar o trabalho para desenvolvimento de habilidades de força e potência. 0 fortalecimento de CORE era essencial para ele, pois devido a desiquilíbrio toda e qualquer atividade em solo que tivesse irregularidade se tornava um risco. Após quase um ano de trabalho começamos a executar os trotes na rua em locais planos e fomos passando para ambientes irregulares, o boné ficou apenas para a lembrança de alguém que o tinha como proteção, seu convívio social com as pessoas a sua volta possibilitou que ele pudesse ter a oportunidade de conhecer pessoas e realizar a troca de experiencia, no ano de 2016 através de uma ligação minha para a mãe, consegui convencer a família a permitir que ele participasse da meia maratona do SESC , $5 \mathrm{~km}$ percorridos em $1 \mathrm{~h} 54 \mathrm{~min}$, e o pódio de um lugar do qual não foi sobre uma taça mas sim por uma escolha, e uma determinação de uma família que nunca desistiu e que passou o bastão para o grande autor desse diálogo.

Mesmo com o sonho de correr realizado, sabia que algo a mais era necessário, resgatar nele os momentos dos quais ele não viveu na sua vida escolar, participar de atividades desportivos e foi na Capoeira que ele continuou a escrever esse capítulo que nunca terá fim.

\section{CONSIDERAÇÕES FINAIS}

\subsection{RELATO DA MÃE}

Foi diante desse trabalho que pude ter a certeza da importância da Educação Física escolar na socialização, autoestima e no desenvolvimento da criança e do adolescente, as limitações existem pela forma como enxergamos o mundo, por um universo com mais ousadia, coragem e determinação. 


\section{REFERENCIAS}

[1] (Leite \& Prado, 2004).

[2] Leite, J. \& Prado, G. (s/d).(2004). Paralisia Cerebral Aspectos Fisioterapêuticos e Clínicos. Revista de Neurociências, 12

[3] (Ferrareto\&Sousa, 1998).

[4] Ferrareto, I., \& Souza, A.M.C. (1998). Paralisia cerebral: aspectos práticos. São Paulo: Frôntis Editorial.

[5] Colledge (1999)

[6] Stainback\&Stainback (1990), Stainback, W.; Stainback, S. Inclusão : um guia para educadores. Porto Alegre: Artes Médicas Sul, 1999._et al. A aprendizagem nas escolas inclusivas e o currículo? In: Inclusão: um guia para educadores . Porto Alegre : Artes Médicas Sul, 1990.

[7] (Zucheto \& Castro, 2002).

[8] Zuchetto A, Castro R. As Contribuições das Atividades Físicas para a Qualidade de Vida dos Deficientes Físicos. Kinesis 2002;26:52-68.

[9] (Llano, Manz, \& Oliveira, 2004)

[10] Llano, M.; Manz, M.; Oliveira, S. Guia prático de atividade física na terceira idade. 2. ed. Cacém: A. Manz Produções, 2004.

[11] (Gallahue et al., 2003).

[12] Gallahue, D. L; Ozmun, J. C. (2003) Compreendendo o desenvolvimento motor: Bebês, crianças, adolescentes e adultos. São Paulo: Phorte editora Ltda

[13] Schwartzman (2004), Schwartzman, S. As causas da pobreza. Rio de Janeiro: Fundação Getúlio Vargas. 2004 


\section{Capítulo 13}

\section{Elementos da gamificação aplicados a objetos de aprendizagem para treinamento de crianças com TDAH}

\section{Déverson Rogério Rando}

Gabriela da Silva Sacchelli

Resumo: Neste trabalho é proposto avaliar se alguns elementos selecionados da gamificação podem auxiliar crianças com TDAH a se manterem motivadas e engajadas durante a realização de tarefas do meio educacional. 0 experimento desta pesquisa consistiu no desenvolvimento de uma aplicação seguindo a metodologia desenvolvida, aliada com atividades que exercitam o raciocínio dos alunos. Para analisar os resultados foram utilizados dois tipos de questionário, um de observação respondido pelos observadores do experimento e o segundo de avaliação voltado a entender as sensações obtidas pelos alunos presentes no momento da aplicação, assim através da análise desses dados pode-se obter uma boa perspectiva, uma vez que todos os alunos concluíram as atividades propostas e os elementos cumpriram os resultados esperados.

Palavras-chave: Gamificação, Jogos, TDAH, Avaliação, Motivação 


\section{INTRODUÇÃO}

Atualmente percebe-se tanto uma preocupação dos profissionais das áreas da saúde e da educação, como também dos pais, em relação a desorganização, desempenho e falta de comprometimento escolar. Tal problema pode estar relacionado ao transtorno do déficit de atenção com hiperatividade (TDAH).

O TDAH é um transtorno neurobiológico, de causas genéticas, que aparece na infância e se caracteriza por uma combinação dos sintomas de desatenção, inquietude e impulsividade. Afeta aproximadamente $5 \%$ das crianças e adolescentes no mundo, independentemente do país no qual o portador vive (IBGE, 2013).

Dados do IBGE demonstram que no Brasil existe cerca de 912 mil crianças de 5 a 12 anos, portadoras do TDAH o que é equivalente a 3,3\% da população infantil, além de outros 625 mil menores que nem sabem que têm a doença, resultando em mais $2,3 \%$ do total. Estes dados demonstram que no mínimo $5 \%$ da população infantil é atingida pelo TDAH, assim como citado anteriormente. (IBGE, 2013).

Crianças com TDAH frequentemente são relatadas como desmotivadas, desligadas e aborrecidas ao realizar tarefas rotineiras. Além destas características é comum apresentarem outros sintomas como intolerância a frustrações, troca constante de atividades e dificuldade de organização, tais sintomas influenciam diretamente em seu desempenho escolar (Joselli, 2014, p. 30).

O TDAH influencia na capacidade de planejar e antecipar consequências, de controlar impulsos, de iniciar e terminar uma ação, de pensar estrategicamente e manter-se atento e motivado na realização das tarefas. Uma maneira de auxiliar no tratamento ao TDAH, é a utilização de jogos de estratégia e raciocínio lógico aplicados de uma maneira que motivem a criança a permanecer jogando e continuar aprendendo. (Barkley, 2014, p. 55).

Devido ao número crescente de pesquisas sobre gamificação em outras áreas, o interesse em seu emprego tem aumentado também no meio educacional. Tal crescente é explicado principalmente, pelo potencial da gamificação em influenciar, engajar e motivar pessoas. Neste contexto o desafio ao aliar gamificação e TDAH está relacionado ao ensino através da motivação ao portador. (Kapp, 2012, p. 11).

Esta pesquisa propõe um método para auxiliar nas dificuldades de concentração, motivação e no desenvolvimento do raciocínio lógico e cognitivo a crianças portadoras do TDAH, aplicando alguns elementos da gamificação para ensinar de forma lúdica, motivacional e engajadora.

\section{GAMIFICAÇÃO}

A gamificação é um tema atual, que se origina diretamente da popularidade dos games, e de suas características únicas de motivar a ação, resolver problemas e potencializar aprendizagens nas mais diversas áreas do conhecimento e da vida dos envolvidos. Com a popularização dos dispositivos móveis, podemos dizer que influência dessa forma de entretenimento é global e atinge praticamente todas as camadas da população.(Fardo, 2014, p. 9).

0 termo gamificação foi definido como a aplicação de elementos utilizados no desenvolvimento de jogos eletrônicos, tais como dinâmica, mecânica, componentes e em outros contextos não relacionados a jogos. (Kapp, 2012, P. 8).

Para solucionar determinados problemas por meio de seus elementos deve-se basicamente pensar como um game designer (desenvolvedor de jogos eletrônicos), uma vez que esse profissional geralmente possui uma excelente capacidade em produzir experiências que concentram a energia e o foco de muitos indivíduos para resolver problemas em mundos virtuais. (Fardo, 2014, p. 19).

Instigados pelo crescente número de pesquisas sobre gamificação em outras áreas, o interesse pela sua aplicação tem crescido cada vez mais também na área da educação. Esta crescente importância pode ser explicada, principalmente, pelo potencial da gamificação para influenciar, engajar e motivar pessoas. (Dominguez, 2013, p.7).

A gamificação originou-se dos games (jogos digitais), concedendo um meio composto por elementos relacionados que, ao se juntarem nos retorna um fenômeno maior do que a soma de todos os seus componentes. Portanto a utilização destes elementos pode ser desde uma parte reduzida, até uma parte mais abrangente de forma a produzir uma experiência próxima de um jogo completo. 
Dessa forma a intensidade que a gamificação será aplicada pode variar a partir da finalidade e resultado esperado no projeto em questão, pois podem ser aplicados apenas elementos básicos como pontos, medalhas e tabela de lideres (rankings), visando proporcionar uma mudança de comportamento através de recompensas convencionais, ou podemos inserir elementos mais complexos de maneira a atingir internamente os indivíduos a desempenharem suas ações da melhor maneira, a partir do contexto em que se encontram (Fardo, 2014, p. 20).

Assim a gamificação proporciona a capacidade de gerar envolvimento entre o indivíduo e a atividade, tornando-se um elemento cada vez mais popular em diferentes ambientes, como em redes sociais e na educação (Bertin, 2016, p. 11).

\subsection{ELEMENTOS DA GAMIFICAÇÃO}

Uma questão importante da gamificação está relacionada em entender como seus elementos foram divididos de forma que se inter-relacionam para criar um ambiente que atenda às necessidades do indivíduo.

Os elementos da gamificação são divididos em três partes: dinâmicas, mecânicas e componentes, como categorias aplicáveis aos estudos e desenvolvimento da gamificação. Estas categorias foram organizadas em ordem decrescente de abstração de modo que cada mecânica se liga a uma ou mais dinâmicas, e cada componente a uma ou mais mecânicas ou dinâmicas conforme a figura 2. (WERBACH \& HUNTER, 2012,p 30)

Figura 1 - Principais elementos da Gamificação.

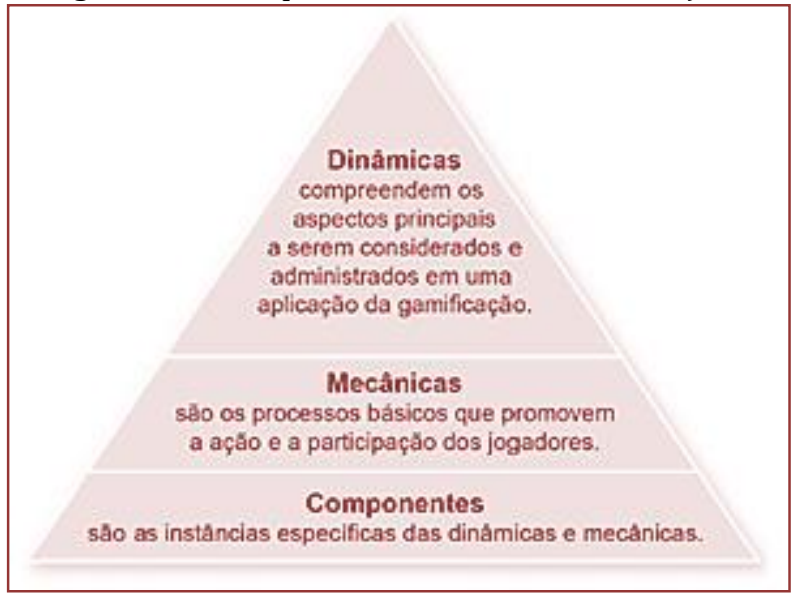

Fonte: Fardo, 2014, p. 43

Combinar as dinâmicas, mecânicas e componentes de forma que sejam efetivas para um determinado objetivo é a tarefa central de um projeto de gamificação. Essa combinação deve ser feita com base no que atende mais adequadamente as demandas de um determinado contexto. (WERBACH \& HUNTER, 2012,p 30)

\subsection{CONQUISTAS, NARRATIVA, NÍVEIS E PONTOS}

Existem vários elementos que constituem a gamificação, para que se tenha sucesso em aplicar elementos da gamificação voltados para a aprendizagem não basta colocar quaisquer e/ou inúmeros elementos e esperar que se tenha resultados positivos, pois muitos elementos podem acabar distraindo o indivíduo causando um resultado negativo, desta forma deve-se analisar o contexto em que será aplicado e os indivíduos que serão atingidos e então a partir daí selecionar os elementos que permitam alcançar os resultados esperados. (Deterding ET. AL., 2011, p. 20)

Desta forma, a seguir serão apresentados e descritos alguns elementos que podem influenciar positivamente sobre os sintomas que os indivíduos com TDAH apresentam. 


\section{Conquistas}

É um tipo de pontos em uma versão mais completa, pois se trata de uma representação gráfica de alguma façanha do usuário no jogo. Assim eles sempre querem receber medalhas dentro de um ambiente por diversos motivos, que vão desde uma experiência agradável de receber a medalha ou por colecionar medalhas.

\section{Narrativa}

A partir dela que é possível fazer com que o jogador tenha uma conduta esperado em um certo contexto. Sendo assim utilizadas para transmitir informações e guiar pessoas, criando uma experiência interativa que engaja o jogador.

\section{Níveis}

Os níveis apontam o progresso do usuário. Sendo diferenciados em três tipos de níveis que são apresentados a seguir (KAPP, 2012, p. 80):

- Níveis de jogo: Devem manter a percepção de que há progresso, aprimorar as habilidades dos indivíduos e motivar.

- $\quad$ Níveis de dificuldade: Um jogo que oferece apenas um nível de dificuldade pode causar uma objeção, pois se for muito fácil pode se tornar entediante, e se for difícil demais afastará as pessoas justamente pela dificuldade.

- Níveis de jogador: responsável por demonstrar a experiência do indivíduo, sendo atribuído de acordo com a realização de tarefas, missões ou desafios.

\section{Pontos}

Este sistema é responsável por motivar os usuários, para isso existem cinco tipos diferentes de pontuação, que serão apresentados a seguir. (Fardo, 2014, p. 23)

- Pontos de experiência: é considerado o mais relevante sistema de pontuação. Estes pontos não são utilizados em um sistema de troca, sua aplicação é através de pontos incrementáveis que conforme o jogador avança, os pontos são incrementados.

- Pontos resgatáveis: são pontos que podem ser trocados por itens de interesse do usuário. Assim conforme o usuário acumula pontos ele pode adquirir itens. Sempre que ocorrem movimentações seu saldo é atualizado, gerando assim uma espécie de comercio virtual.

- Pontos de habilidade: são concedidos a tarefas específicas, não estando relacionada com os principais objetivos.

- $\quad$ Pontos de carma: são pontos que pertencem ao usuário e que ele pode compartilhar com outra pessoa. Criando um senso de popularização e compartilhamento entre as partes

- Pontos de reputação: é aplicado quando há a necessidade de confiança entre duas ou mais partes.

\section{METODOLOGIA}

Existem vários elementos que constituem a gamificação, porém devemos selecionar apenas os elementos que permitam alcançar os resultados esperados, pois o uso de muitos elementos pode causar uma dispersão dos fatores predominantes. (Deterding ET. AL., 2011, p. 20).

Os principais sintomas do TDAH presentes em crianças em idade escolar são nos campos da atenção, concentração e impulsividade, o que acaba causando uma maior dificuldade de aprendizado, as deixando atrasadas em relação aos outros alunos. (Legnani ET AL., 2006, p. 8).

Desta forma, através da análise dos trabalhos correlatos e da definição dos elementos e benefícios da gamificação, foi observada uma possível relação entre a narrativa, as conquistas, os níveis e os pontos com os sintomas do TDAH. A seguir será realizada uma descrição dos meios em que os elementos devem ser inseridos. 
A conquista é um elemento responsável por motivar o usuário através da representação visual de medalhas e troféus, assim a conquista será utilizada para beneficiar a progressão do jogador ao concluir um objetivo dentro do sistema, sendo apresentada logo depois de concluída. Devido ao fato de que terá diversas conquistas no decorrer da aplicação, ao final deve ser possível que o jogador visualize todas as conquistas obtidas como uma forma de coleção de conquistas. Além disso, conforme obtêm as conquistas o jogador terá acesso a áreas e personagens anteriormente bloqueados. (Fardo, 2013, p. 10).

Já a narrativa consiste em transmitir informações e guiar o jogador, formando um significado, um maior aprofundamento e interação entre o narrador e o ouvinte. Ela será aplicada como uma forma de conduzir o jogador pelos objetivos e atividades através da formulação de uma história, que visa promover um sentido aos acontecimentos, sendo responsável por unir os outros elementos da gamificação, trazendo a sensação de avanço no jogo. (Kapp, 2012, P. 18).

Os níveis geram a percepção de que há progresso e proporcionam engajamento ao jogador. Existem vários tipos de níveis, porém será utilizado apenas os níveis de jogador que se relacionará diretamente com os pontos de experiência, onde conforme acumular uma quantia de pontos de experiência seu nível de jogador aumentará. (Fardo, 2014, p. 21).

0 último elemento selecionado foram os pontos, sendo ele o principal sistema responsável por motivar os jogadores. Como nos níveis os pontos também são divididos em diversas opções, assim foi escolhido apenas os pontos de experiência que consiste em contemplar o jogador com pontos conforme ele conclui os objetivos propostos, sendo que a quantidade de pontos que será atribuída se dará conforme o tempo e número de erros utilizados para realizar tal objetivo. Estes pontos estarão diretamente relacionados com os níveis do jogador, assim conforme um número de pontos seja atingido ele subirá de nível. (COSTA e MARCHIORI, 2015, p. 32).

\subsection{DESENVOLVIMENTO COGNITIVO}

Os jogos que obtiveram melhores resultados aplicados a crianças e jovens com TDA foram de potencialização da memória, solução de problemas e jogos que necessitavam de pensamento rápido. Desta forma será desenvolvido o protótipo de um objeto de aprendizagem(jogo) que terá como enredo a estória do livro "A Caverna Escura", escrita por um menino aos 8 anos de idade, diagnosticado com déficit de atenção.

Da história surgirão, como uma forma de desafio, as atividades de raciocínio matemático, raciocínio lógico, memória e visual, onde:

- a atividade de raciocínio matemático deverá conter expressões matemáticas e disponibilizar algumas respostas onde apenas uma estará correta e após um número de acerto se concluirá;

- a atividade de raciocínio logico se dará através de um jogo de quebra cabeça onde o jogador deve girar as imagens até formar a imagem final;

- $\quad$ a atividade de memória será através da formação de pares das cartas correspondentes;

- e por fim, a atividade visual estará na forma de um jogo dos 7 erros onde deve-se encontrar as diferenças entre duas imagens. (Rocha ET AL, 2014, P. 23)

Todas as atividades irão gerar um número de erros, acertos e o tempo necessário para realiza-la, além de contemplar o jogador com conquistas para mantê-lo motivado a continuar jogando.

\subsection{AVALIAÇÃO DO MODELO}

Para avaliar o jogo digital a ser desenvolvido utilizando, se faz necessário definir alguns parâmetros que serão analisados para identificar se o comportamento do usuário foi satisfatório na realização das atividades contempladas com a gamificação.

Uma forma de mensurar tal comportamento sugere a análise do tempo verificando tentativas sequenciais, rápidas e repetidas na tentativa de acertar uma questão, ou quando ele não sabe a resolução e clica repetidas vezes em alternativas aleatórias, além de verificar se todos os objetivos estão sendo cumpridos. Para análise e registro desse comportamento, foram propostas as seguintes variáveis: (Barker ET AL. 2008, P. 35). 
- Tempo para responder uma atividade: esta analise se inicia assim que o usuário recebe a atividade, até o momento em que ele escolhe uma alternativa.

- Contemplações: toda pontuação, nível e conquistas obtidas são armazenadas, até a conclusão do jogo.

- Quantidade de erros: toda vez que não é concluído uma atividade em um determinado tempo, é registrado o número de vezes necessárias para conclui-la.

- Tempo final: é registrado o tempo que foi utilizado para concluir todas as atividades necessárias para finalizar o jogo.

- $\quad$ Além deste modelo, também será utilizado o modelo estruturado com base em um questionário para coleta de dados através da percepção do usuário, avaliando os níveis de conhecimento, compreensão e aplicação. (Savi ET AL., 2010, p.9)

- $\quad 0$ questionário deve possuir variados aspectos de parâmetros, sendo apresentadas perguntas em forma de afirmações para que os usuários indiquem o quanto concordam com elas, levando em consideração como auxiliar de resposta uma escala de 1 a 5 pontos variando de "Discordo Totalmente" até "Concordo Totalmente". Assim seguindo estes modelos será possível identificar se a gamificação pode cumprir com os resultados esperados de manter o usuário focado e motivado durante a realização das atividades.

\subsection{EXPERIMENTO}

\subsection{DESCRIÇÃO E CONSTRUÇÃO}

Para realizar o experimento, foi necessário desenvolver um jogo e inserir os elementos da gamificação. Para isso foi escolhido entre as várias plataformas disponíveis a que apresenta um dos melhores índices de uso, os computadores, é um dos mais utilizados meios de entretenimento do mundo. (Pedro, 2016, p.9),

Entre os elementos selecionados se encontra a narrativa, que no jogo foi inserida em forma de textos e diálogos entre os personagens, sendo baseado em uma história escrita por uma criança com TDAH, nela existe um personagem principal que conforme avança pelo cenário encontra obstáculos e objetivos que resultam na aplicação das atividades, que podem ser dos tipos de raciocínio matemático, lógico, memória e visual.

Um detalhe importante é que o jogo seguiu uma estrutura linear em um plano 2D, além de limitar o movimento do personagem apenas ao eixo x, afim de que ele não realize movimentações desnecessárias que podem diminuir sua concentração.

As atividades inseridas através dos obstáculos no decorrer da história, foram desenvolvidas conforme descrito a seguir: o jogo dos sete erros apresenta duas imagens onde o jogador deve encontrar as diferenças entre elas, tendo como condições de vitória encontrar as sete diferenças em um tempo máximo de dois minutos e com um número de tentativas menor que 15.

Outro tipo de atividade desenvolvida foi um desafio matemático, onde eram geradas expressões matemáticas e o jogador deveria selecionar uma das três respostas possíveis, a fim de respondê-las, seu termo de vitória consiste em acertar o resultado de seis expressões em menos de dois minutos.

A terceira atividade é um tipo de quebra cabeça, onde o jogador deve girar várias imagens a fim de encontrar uma imagem final, seu estado de conclusão é atingido quando encontrada a imagem final em menos de dois minutos.

Por fim foi criada uma atividade de jogo da memória que apresentava dez cartas onde o jogador deve encontrar seus respectivos pares, sendo concluída quando encontrados em menos de dois minutos. Todas as atividades descritas utilizam de uma condição importante de não criar nenhum tipo de punição ou condição de derrota, tendo em vista que isso tenderia a desmotivar o jogador, assim quando não completa a atividade, a narrativa surge como uma forma de incentiva-lo a tentar concluir a atividade novamente.

Quando concluída o jogador é beneficiado com o desbloqueio de conquistas e recebe pontos de experiência que variam de acordo com o tempo, número de erros e número de acertos consecutivos. Onde a quantidade acumulada reflete no nível do jogador, a seguir é apresentado como foi definido os parâmetros de aumento de nível a partir da quantidade de pontos conquistados: 
Tabela 1 - Relação entre quantidade de pontos de experiência acumulados e o nível do jogador

\begin{tabular}{|c|c|}
\hline NÍVEL & QUANTIDADE PONTOS \\
\hline 1 & 0 à 100 \\
\hline 2 & 100 à 250 \\
\hline 3 & 250 à 450 \\
\hline 4 & 450 à 700 \\
\hline 5 & maior que 700 \\
\hline
\end{tabular}

Fonte: Autor

Na tabela 1, é demonstrado qual foi a condição de pontos de experiência a serem acumulados, para possibilitar que o nível do jogador seja incrementado em uma unidade conforme atingir tais quantidades pré-estabelecidas. Outro detalhe é que toda vez que sobe de nível o jogador é recompensado com uma conquista.

A representação gráfica do nível do jogador e pontos de experiência foi inserida de modo a ser visualizada em todos os ambientes do jogo, para que assim enfatize ao jogador seu progresso no jogo, o que gera a vontade de se conquistar mais pontos e consequentemente subir de nível.

Assim como nos pontos e níveis do jogador, as conquistas também são relacionadas com uma realização para desbloqueá-las, porém nesse caso são objetivos secundários. Lembrando que o principal atrativo das conquistas é a motivação que ela causa no jogador quando contemplado e o engajamento com a necessidade de desbloquear todas elas e finalizar o jogo por completo. Os requisitos estabelecidos para serem atingidos, também estão previamente definidos conforme a tabela abaixo.

Tabela 2 - Relação entre as conquistas desbloqueáveis e as ações necessárias para atingi-las

\begin{tabular}{|c|c|}
\hline CONQUISTA & REALIZAÇÃO \\
\hline Iniciou o jogo. & Ao iniciar o modo história o jogador receberá esta conquista. \\
\hline Coisas Estranhas. & $\begin{array}{c}\hat{E} \text { atribuída esta conquista, assim que encontrado o } \\
\text { primeiro desafio. }\end{array}$ \\
\hline Bem vindo a caverna. & $\begin{array}{c}\text { Assim que completa o primeiro desafio, é passado de fase } \\
\text { e liberada esta conquista. }\end{array}$ \\
\hline Amigo robô encontrado. & $\begin{array}{l}\text { Ao concluir o segundo desafio, é indicado está } \\
\text { conquista e desbloqueado o personagem robô. }\end{array}$ \\
\hline Senha do cadeado & Atribuída assim que concluído o terceiro desafio. \\
\hline O destruidor & Liberada quando atingido o quarto desafio. \\
\hline Saída Encontrada. & $\begin{array}{l}\text { Ao chegar no ultimo desafio está conquista é obtida, } \\
\text { e o personagem vampiro é desbloqueado. }\end{array}$ \\
\hline $\begin{array}{l}\text { Completou o } \\
\text { Modo Historia }\end{array}$ & $\begin{array}{c}\text { Assim que completa o modo história o jogador recebe } \\
\text { esta conquista, além de desbloquear a personagem } \\
\text { avó e o menu de desafios. }\end{array}$ \\
\hline Fácil demais & $\begin{array}{l}\text { Quando completado todos os desafios desbloqueados } \\
\text { no menu, é atingida esta conquista. }\end{array}$ \\
\hline
\end{tabular}

Fonte: Autor

Na tabela 2, é demonstrado qual foi a relação criada entre as conquistas e os objetivos necessários para obtê-las. Conquistas também exibem uma representação gráfica, porém elas são apresentadas somente quando o jogador atinge um determinado acontecimento, após isso caso queira verificar quais conquista desbloqueou, deve-se acessar a área de "Conquistas" presente no menu do jogo, onde são apresentadas as conquistas bloqueadas e as desbloqueadas.

Para finalizar, o uso da narrativa foi aplicado através dos diálogos entre os personagens e as atividades, bem como na contemplação dos acertos e no incentivo quando não concluído uma atividade. A narrativa é essencial para a gamificação, pois introduz um significado para o jogo, fornece um contexto e guia as ações dos jogadores por meio do seu enredo. Assim no meio educacional, a história pode ser elaborada como 
uma forma de ensinar ou apresentar lições. Visando um melhor entendimento de como foi realizado o controle da narrativa, das atividades, pontos e conquistas foi desenvolvido um fluxograma seguindo todos os conceitos e técnicas deste trabalho, tornando claro o meio em que foram empregados.

O fluxograma é uma excelente ferramenta para caracterizar um método ou procedimento, que utilizam uma combinação de processos.

Figura 2 - Fluxograma do Jogo

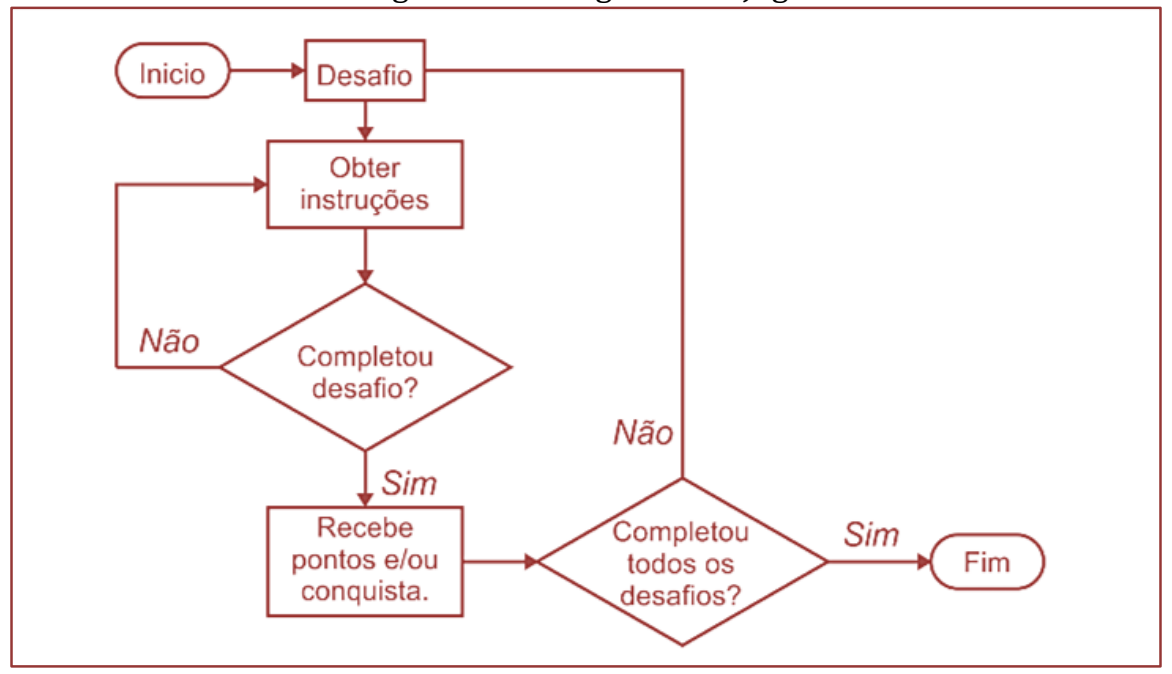

Fonte: Autor

A figura 3 apresenta um fluxograma, de como é realizada as tomadas de decisões e aplicação da metodologia dentro do jogo.

\subsection{QUESTIONAMENTOS E AVALIAÇÕES}

Visando avaliar o jogo e a metodologia proposta nesta pesquisa, foi conduzido um experimento na cidade de Apucarana, no estado do Paraná, nas dependências da FAP (Faculdade de Apucarana), que disponibilizou um laboratório de informática para receber um grupo de alunos.

No dia estava presente o professor Eduardo de Souza Hashimoto, coordenador do curso de psicologia da FAP, que auxiliou neste experimento, através da disponibilização de um grupo de três crianças, formado por meninos, com idades entre 9 e 10 anos, sendo todos estudantes do ensino fundamental.

Então foi aplicado o jogo desenvolvido a fim de se obter respostas para as seguintes perguntas.

- A Gamificação através dos pontos de experiência, níveis de jogador, conquistas e narrativa aumenta a motivação e ajudam a encorajar o aluno durante o uso do jogo?

- As mecânicas de jogos melhoram o desempenho dos alunos durante o uso do jogo?

- A pontuação e nível de experiências atingidas foram eficazes para motivar o aluno a jogar novamente?

- Os alunos se mantiveram focados no jogo durante a realização do experimento?

- Qual a porcentagem de alunos que completaram todas as atividades presentes no jogo?

- $\quad 0$ jogo foi bem recebido pelos alunos?

Para levantar dados de modo a responder tais perguntas foram utilizados os seguintes meios:

A primeira forma de dados foi obtida a partir dos resultados gerados pelo jogo, que conforme o aluno jogava e avançava, os dados eram armazenados na memória, o que gerou uma série de resultados em relação ao tempo, pontos, níveis e conquistas, atingidos por cada jogador e que serviram como uma forma de detectar os resultados desta metodologia. 
Para o segundo meio, foi elaborado um questionário de observação contendo 8 perguntas em relação ao comportamento das crianças durante o jogo, no qual este questionário foi aplicado ao professor e psicólogo Eduardo Hashimoto, e ao professor Déverson Rando, ambos presentes no momento da realização do experimento, onde por meio de suas observações, assinalaram que suas impressões em relação ao comportamento das crianças.

Assim a terceira e última etapa de aquisição de dados, foi através da aplicação de um questionário de avaliação, que consistiu em 10 questões, onde as 3 primeiras eram em relação ao gênero, idade e ao aspecto comportamental em relação a jogos, a fim de identificar se através destes fatores houve diferenças na percepção dos alunos e dos resultados. As outras sete questões eram em relação ao sentimento que os alunos obtiveram durante o uso do jogo.

Para cada pergunta do questionário era disponibilizado a opção de resposta em forma escalar de 1 a 5 , onde 1 representava "Não Gostei" e 5 "Gostei Demais". Através destes dados foram realizada uma serie de analises a fim de responder os questionamentos propostos neste trabalho. A seguir no próximo capítulo serão demostrado os resultados obtidos.

\section{RESULTADOS}

A tabela 3 apresenta os resultados gerados pelo elementos inseridos no jogo que cada aluno obteve, onde pode ser analisado que todos obtiveram uma boa pontuação e alcançaram um bom nível de jogador, outro detalhe importante é que todos os alunos concluíram as atividades e consequentemente o jogo, onde o tempo médio foi de cerca de10 minutos e 33 segundos.

Tabela 3 - Resultados

\begin{tabular}{|c|c|c|c|}
\hline & $\begin{array}{c}\text { TEMPO } \\
\text { FINAL }\end{array}$ & $\begin{array}{c}\text { PONTUAÇÃO } \\
\text { CONQUISTADA }\end{array}$ & $\begin{array}{c}\text { NÍVEL } \\
\text { ATINGIDO }\end{array}$ \\
\hline Aluno A & $8: 43 \mathrm{~s}$ & 716 & 5 \\
\hline Aluno B & $9: 24 \mathrm{~s}$ & 523 & 4 \\
\hline Aluno C & $14: 55 \mathrm{~s}$ & 384 & 3 \\
\hline
\end{tabular}

Fonte: Autor

Durante o experimento observou-se que os principais benefícios destes elementos, foram criar a motivação para que o aluno jogasse novamente com a intenção de melhorar seu o tempo, pontuação e nível.

A partir dos dados obtidos no questionário de avaliação respondido pelos alunos, foi realizada a análise dos resultados.

$\mathrm{Na}$ questão um, tratou-se de identificar se os alunos gostaram do meio em que a história, as atividades e a narrativa se complementaram. Os resultados foram nota 3 com 66,7\% e nota 4 com 33,3\%, assim percebese que os resultados deste meio não agradaram por completo.

Quanto ao envolvimento em relação aos pontos, níveis e conquistas foram realizadas três perguntas, mais especificamente as questões dois, três e quatro. Onde as respostas apresentaram uma boa nota, pois foram atribuídos os valores 4 e 5 em quase todas as respostas.

A pergunta cinco confirma esta observação, uma vez que ela questiona os alunos sobre a sensação de progresso, sendo bem avaliado com notas 4 e 5.

A pergunta sete que questionava sobre o fato de se jogar novamente o jogo apresentou um bom resultado uma vez que nenhum dos alunos escolheu a opção "não".

Em relação ao questionário de observação, mais precisamente nas questões um e dois, pode-se analisar que o comportamento dos alunos e do ambiente foi aceitável, onde os resultados das notas atribuídas foram 4 e 5 .

Analisando as questões três, cinco e seis, que eram voltadas a avaliar qual foi o resultado das conquistas, níveis e pontos, é possível visualizar que os efeitos podem ser considerados positivos, uma vez que as notas atribuídas foram maiores ou iguais a 4 . 
Sobre a questão quatro, no qual foi questionada sobre os resultados da narrativa inserida no jogo através de textos e diálogos, a nota atribuída por ambos os observadores foi 3 , tendo como justificativa a dificuldade apresentada por alguns alunos em ler e entender o contexto da história e das atividades.

As questões sete e oito avaliaram a possível eficácia do jogo em desenvolver o cognitivo dos alunos, bem como a recomendação dos observadores em relação ao jogo e metodologia desta pesquisa. Os resultados agradaram, uma vez que se obteve $100 \%$ de recomendação e nota 5 em uma possível melhora cognitiva.

\section{CONCLUSÃO}

A gamificação é um conceito que tem sido utilizada nas mais diversas áreas com intuito de, auxiliar na motivação e engajamento de pessoas no alcance de um objetivo específico. Na educação, a gamificação permite que o aluno se divirta enquanto aprende, tornando o processo de aprendizagem mais engajador e motivador para alunos e professores.

É dentro dessa área que esta pesquisa se insere, com intenção de auxiliar crianças com o diagnóstico de TDAH. Assim, neste trabalho foi proposto avaliar se o uso de elementos da gamificação inseridas em um jogo para o desenvolvimento cognitivo aumentam o engajamento e a motivação de seus usuários, uma vez que eles tenham TDAH, um transtorno que entre os principais sintomas estão a dificuldade de se concentrar e concluir uma determinada tarefa.

Conforme demonstrado existe uma grande quantidade de elementos da gamificação, porém os conceitos escolhidos levaram em consideração a sintonia entre os elementos e os sintomas apresentados pelos TDAH.

Os resultados obtidos com esta metodologia podem ser considerados satisfatórios conforme mostrados nos resultados deste trabalho, onde os pontos de experiência, os níveis de jogador e as conquistas, cumpriram seus respectivos papeis.

Já a narrativa em forma de texto não obteve um resultado expressivo e conforme analisado foi constatado uma dificuldade apresentada pelos alunos em ler e entender seu contexto e instruções, uma forma para tentar melhorar este resultado é acrescentar a narrativa em forma de áudio, o que facilitaria a imersão do aluno com a mesma.

Em relação aos experimentos realizados, apesar dos resultados terem sido positivos, uma melhoria seria a criação de um grupo de controle e de novos experimentos com um número maior de alunos a fim de se confirmar os resultados obtidos. Outra possível melhoria seria avaliar se há diferença nos resultados a partir do gênero do aluno.

Como trabalhos futuros é proposto melhorar os fatos acima mencionados, além de testar outros elementos da gamificação, como a aplicação de níveis de dificuldades nas atividades inseridas no jogo, e aplicar a interação social por meio de rankings, visando a motivação por meio da superação de resultados. Também se espera desenvolver novas atividades com base em inteligência artificial que comprovem o desenvolvimento cognitivo, o que consequentemente aumentaria a qualidade e o tempo necessário para se concluir as atividades.

\section{REFERÊNCIAS}

[1] Bertin, R. et al. Elementos de gamificação nos softwares de autoria. Caxias do Sul. 101 p., 2014. Monografia (Graduação) - Universidade de Caxias do Sul.

[2] Deterding, S. et al. From game design elements to gamefulness: defining gamification. In: ACM. Proceedings of the 15th international academic MindTrek conference: Envisioning future media environments. [S.l.], 2011. p. 9-15.

[3] Fardo, M. L. A gamificação como estratégia pedagógica: estudo de elementos dos games aplicados em processos de ensino e aprendizagem. Caxias do Sul, 104 p. 2014. Dissertação (Mestrado) Universidade de Caxias do Sul

[4] IBGE, I. B. d. G. e. E. Educação. [S.l.]: Instituto Brasileiro de Geografia e Estatística - IBGE, 2013. ISBN 15163296.

[5] Joselli, M. A ética e os games: “morais, imorais ou amorais?”. um estudo sobre a ética em games segundo aristóteles, santo agostinho e kant. In: Anais do Congresso da Sociedade brasileira de Computação, Brasília, DF, Brasil. [S.I.], 2014. 
[6] Barkley, R. A. Attention-deficit hyperactivity disorder: A handbook for diagnosis and treatment. [S.l.]: Guilford Publications, 2014. p. 30-45

[7] Kapp, K. The Gamification of Learning and Instruction: Game-based Methods and Strategies for Training and Education. Wiley, 2012. ISBN 9781118191989.

[8] Legnani, V. N. et al. Impasses na construção da noção de alteridade nos processos de subjetivação das crianças com o diagnóstico de transtorno de déficit de atenção e hiperatividade (tda/h). Colóquio do LEPSI IP/FE-USP, SciELO Brasil, v. 5, 2006.

[9] Pedro, L. Z. Uso de gamificação em ambientes virtuais de aprendizagem para reduzir o problema da externalização de comportamentos indesejáveis. São Paulo, 130 p. 2016. Tese (Doutorado) — Universidade de São Paulo.

[10] Rocha, P.; Filho, J. N.; ALVES, L. Jogos digitais e reabilitação neuropsicológica: delineando novas mídias. Anais do Seminário Tecnologias Aplicadas a Educação e Saúde, v. 1, n. 1, 2014.

[11] Savi, R. et al. Proposta de um modelo de avaliação de jogos educacionais. Renote, v. 8, n. 3, 2010.

[12] Werbach, K.; Hunter, D. For the win: How game thinking can revolutionize your business. [S.l.]: Wharton Digital Press, 2012. 


\section{Capítulo 14}

\section{Educação especial e a importancia do diagnóstico multidisciplinar e da intervenção cognitiva}

\section{Rosemeire Quilante Azevedo}

Angélica Biazus Mendonça da Fonseca

Marcos Magalhães Vasquez

Resumo: Introdução: 0 diagnóstico multidisciplinar permite uma visão ampla das dificuldades e potencialidades das crianças, pois se trata de um processo compartilhado de coleta de informações que poderão nortear as intervenções adequadas, e acesso ao currículo escolar. Objetivo: Realizar uma discussão sobre a avaliação diagnóstica multidisciplinar e a sua importância para a realização de intervenções eficazes que tragam melhorias para a capacidade adaptativa e cognitiva das crianças. Metodologia: Trata-se de uma pesquisa exploratória qualitativa em formato de estudo de caso. Foi realizada uma avaliação multidisciplinar e intervenção psicopedagógica e fonoaudiológica. Para a comparação dos resultados foi aplicada a Escala Wechsler de Inteligência para crianças - WISC- IV, antes e depois das intervenções. Resultados: A criança apresentou o coeficiente de inteligência aumentado de QI T 70 para QI T 89 e um substancial desenvolvimento na compreensão verbal, organização perceptual, mostrando que as terapias fonoaudiológica e psicopedagógica contribuíram para a modificabilidade cognitiva estrutural da criança.

Palavra chave: Educação especial; Aprendizagem; Intervenção cognitiva; Criança. 


\section{A INTRODUÇÃO}

Um dos grandes desafios da educação no Brasil é o diagnóstico e intervenção de crianças público alvo da Educação Especial.

Em alguns países da Europa, como Portugal e Espanha, o diagnóstico e a intervenção de crianças com necessidades especiais transcendem a área da educação e da saúde, pois são divulgados em nível nacional para melhorar a condição da criança com deficiência, através de ações também políticas e sociais. (ROYO,2012).

O diagnóstico multidisciplinar permite uma visão ampla sobre as necessidades educativas especiais das crianças, pois se trata de um processo compartilhado de coleta de informações que poderão nortear as intervenções adequadas, levando em conta as peculiaridades para o seu acesso ao currículo escolar.

Na literatura internacional existem estudos que descrevem o uso de programas eficazes de intervenção cognitiva e outras habilidades necessárias para o desempenho acadêmico. (ALMEIDA 2002)

A educação visa em todos os sistemas, o desenvolvimento das potencialidades dos alunos. Os indivíduos afetados por algum tipo de deficiência devem receber atendimento específico que ajudem no seu desenvolvimento. (ROYO, 2012)

A intervenção cognitiva, é um dos caminhos para melhorar a condição da criança, também contribui para encorajar o desenvolvimento de processos pedagógicos, como por exemplo, o de pensar em um plano de desenvolvimento individual, que permitam o acesso da criança ao currículo escolar.

Em casos de transtornos do processamento auditivo diagnosticados, são indicados programas baseados no treinamento auditivo, o emprego de estratégias de linguagem cognitivas e metacognitivas, os quais promoverão a plasticidade e a reorganização cortical (SALEMI,2009).

Partindo da concepção de Feuerstein (2014), a inteligência é modificável através da Experiência da Aprendizagem Mediada- EAM e tem uma visão otimista sobre a educação, quando ressalta que toda criança é capaz de aprender, independente da sua dificuldade ou deficiência, desde que sejam desenvolvidas as suas funções cognitivas.

Em 1980, o neuropsicólogo romeno criou a Teoria da Modificabilidade Cognitiva, que tem como suporte a neuroplasticidade cerebral e desenvolveu sua pesquisa com crianças vítimas do holocausto da Segunda Guerra Mundial. Atualmente neurociência traz evidencias da modificabilidade cognitiva e agindo no comportamento observável e na atividade e estrutura neurológica. (FEUERSTEIN,2014)

As funções cognitivas são responsáveis pelo ato mental. Um aluno com deficiência nas funções cognitivas terá dificuldade para assimilar conceitos, planejar estratégias para a solução de problemas, perceber dados relevantes e para elaborar o seu pensamento. (ALMEIDA 2002).

A eficácia da intervenção cognitiva em qualquer área de atuação, depende da qualidade da mediação, que garante uma intencionalidade, reciprocidade entre a criança e o especialista, que resultará em uma transcendência da aprendizagem para outros contextos.

Oferecer um diagnóstico para a criança não significa engessá-la numa definição de deficiência ou patologia, ao contrário, o diagnóstico multidisciplinar realizado por diferentes profissionais, permite uma visão ampla sobre as suas dificuldades específicas e pode diminuir efeitos secundários, quer no aspecto social, quer no aspecto cognitivo e afetivo.

\section{MÉTODOS}

Trata-se de um estudo de caso de uma criança de nove anos, encaminhado pela escola, com queixa de baixo rendimento escolar, para realizar uma avaliação multidisciplinar em consultório clínico.

A avaliação multidisciplinar consistiu em:anamnese, avaliações neuropsicológica, psicopedagógica e fonoaudiológica, Exame do Processamento auditivo Central - PAC e neurológicos.

Ao final de cada avaliação, em reunião multidisciplinar, discutiram-se aspectos relevantes da avaliação, formulando hipóteses baseados nos exames coletados e nos manuais médicos de diagnóstico DSM IV (APA, 2002) e CID 10 (OMS,2000). Em seguida, foi realizado um relatório contendo todas as informações e proposta de intervenção para serem explicadas na devolutiva à família e posteriormente à escola. 
Na devolutiva sugeriu-se o treinamento das funções cognitivas através do Programa de Enriquecimento Instrumental - PEI e o treinamento do Processamento Auditivo Central - PAC em sessões semanais de 50 min para cada intervenção.

Foi selecionada a Escala Wechsler de Inteligência para crianças - WISC-IV, para comparação dos resultados relacionados aos aspectos cognitivos, perceptivos, atencionais e de comunicação antes e depois das intervenções.

Esse estudo foi realizado após assinatura do Termo de Consentimento Livre e Esclarecido (TCLE) e atende às normas do Comitê de Ética em Pesquisa da Pontifícia Universidade Católica de São Paulo.

\section{PROCEDIMENTOS}

\section{Fase 1}

Coleta de dados através da anamnese e da entrevista com a escola e do exame trazidos pela mãe - PAC.

Avaliação multidisciplinar: neuropsicológica, fonoaudiológica e psicopedagógica.

Fase 2

Intervenção cognitiva através do Programa de Enriquecimento Instrumental: 50 sessões de 1 hora. Treinamento do Processamento Auditivo Central (16 sessões de $50 \mathrm{~min}$ )

Fase 3

Reaplicação da Escala Wechsler de Inteligência para crianças - WISC- IV para comparação do desempenho do paciente.

\section{Estudo de caso}

A entrevista de anamnese foi realizada com os pais seguindo um protocolo padronizado e elaborado pelo grupo. Esta anamnese continha questões referentes a identificação, histórico escolar, histórico médico.

Os dados relevantes coletados na anamnese referem-se ao Peri e pós-natal. A criança tem descendência japonesa. 0 paciente apresentou tremores e hipoglicemia após o nascimento, ficando internado para a realização de exames neurológicos. Falou com 4 anos e o desfralde também aconteceu neste período. Sempre foi dependente para as atividades de vida diária e interage com crianças mais novas.

Seu relacionamento com os pais e com os avós é de superproteção. Ainda dorme com a mãe.

"Meu filho não é uma criança competitiva, ele não se preocupa em ser o melhor, isto é, não se preocupa em perder" - sic mãe.

A mãe estuda com o filho e o ajuda nas lições de casa.

\section{- Queixa escolar}

Segundo o relato da coordenadora pedagógica e da professora, a criança não tinha iniciativa e apresentava dificuldade para compreender conceitos e estava defasado com relação aos conteúdos. 0 seu discurso era infantilizado prejudicando a sua interação com os colegas de sua idade. Apresentava dificuldades para compreender comandos e necessitava de apoio individual.

\section{- Avaliação fonoaudiológica}

A avaliação fonoaudiológica foi realizada com ênfase nos aspectos de linguagem e cognição. As sessões de avaliação foram gravadas em vídeo, para posterior análise.

Nas atividades referentes à criação de histórias, percebeu-se que ele apresentou dificuldade em marrá-las, e às vezes, não demonstrava coerência. 
No desenvolver da avaliação foram utilizados jogos, livros e materiais específicos levando-se em consideração os objetivos da avaliação. Ao jogar não conseguia manter-se concentrado por muito tempo, mesmo sem ter terminado, sempre escolhia outro jogo.

Foi observado que a criança apresentou pouca intenção comunicativa, e quase não possuía troca de turno com a avaliadora.

Nos jogos propostos, o qual tinha como objetivo analisar a compreensão da linguagem e habilidade de leitura e escrita, a criança apresentou dificuldade na leitura e na compreensão do que acabou de ler. Não mantinha a concentração na maioria das vezes, o que poderia influenciar todo o processo de aprendizagem.

Sua fala apresentava-se um pouco inteligível, não conseguindo expressar-se, ou seja, apresentou dificuldade em completar seu raciocínio, fugindo às vezes da realidade.

No que diz respeito ao exame de PAC, este demonstrou prejuízo em algumas habilidades, porém, talvez somente o exame não justificou todos esses comprometimentos de aprendizagem.

\section{- Análise dos profissionais}

\section{Psicopedagógica}

$\mathrm{Na}$ avaliação psicopedagógica foram observados os aspectos cognitivos relacionados a memória, comparação, classificação, percepção analítica e raciocínio lógico.

Foram aplicadas as provas operatórias de Jean Piaget e o Teste de Audibilização.

0 desempenho da criança nas provas operatórias foi classificado como nível 1 , correspondente à idade mental de 5 a 6 anos, demonstrando ausência da noção de conservação, da inclusão e intersecção de classes.

Nas provas de quantidade, a criança não conseguiu manter o critério da quantidade de fichas brancas e pretas, pois a sua percepção analítica encontrava-se em defasagem. Também não adquiriu, com propriedade, a noção de conservação de peso.

Nas provas de classificação e intersecção de classes não estabeleceu critérios que justificassem as suas respostas. Sentiu dificuldade para fazer pareamentos, isto é, para ordenar objetos do menor para o maior. Em atividades com jogos, a criança apresentou dificuldade de análise e síntese, pois não conseguia fazer antecipações, levantar hipóteses ou planejar estratégias, sem a ajuda da especialista e dificuldade para compreender conceitos. A criança se perdia ao contar ou registrar uma sequência de números menores que 10, pois confundia ordem, esquecia as informações anteriores.

Com relação a comunicação oral, a criança apresentou dificuldade para se expressar, pois suas frases eram desconexas e muitas vezes sem sentido ou sem lógica: "A cadeira está voando", e não parecia estar imaginado. Não conseguia manter um diálogo coerente, pois se perdia na sequência lógica dos fatos.

Diante disto, percebeu-se uma ausência de conduta comparativa e de comportamento exploratório, deficiência na compreensão de conceitos espaciais e temporais, deficiência na capacidade de conservar constâncias, certa tendência a focar apenas na aparência imediata do objeto, sem fazer relações, imprecisão na coleta de dados, e percepção confusa e superficial, que precisam ser trabalhados.

Em atividades como desenhos e criação de histórias, a criança apresentou pouca criatividade e um vocabulário bastante reduzido. Teve dificuldade para narrar uma história, pois apresentou uma percepção confusa e superficial da realidade.

No teste de audibilização a criança apresentou um prejuízo na memória de curto prazo, na percepção auditiva, na discriminação fonética e na conceituação e construção de frases.

Nas provas conceituais observou-se um baixo desempenho para conceituar objetos, identificar absurdos e relatar fatos em sequência. 


\section{Neuropsicológica}

Durante a aplicação da Escala Weschsler de inteligência para crianças: WISC- IV, observou-se muita dificuldade da criança em compreender as tarefas e precisou da mediação do especialista para que cada tarefa fosse executada. Os resultados estão expostos no quadro abaixo:

Resultados da primeira avaliação nos subtestes e índices avaliados

Quadro da Escala Weschsler de inteligência para crianças: WISC- IV

\begin{tabular}{|c|c|c|c|c|c|}
\hline & $\mathrm{CV}$ & $\mathrm{OP}$ & MO & VP & QIT \\
\hline Cubos & & 8 & & & \\
\hline Semelhanças & 5 & & & & \\
\hline Dígitos & & & 5 & & \\
\hline Conceitos & & 7 & & & \\
\hline Código & & & & 6 & \\
\hline Vocabulários & 4 & & & & \\
\hline SNL & & & 5 & & \\
\hline Raciocínio & & 10 & & & \\
\hline Compreensão & 4 & & & & \\
\hline Símbolos & & & & 7 & \\
\hline Figuras & & 5 & & & \\
\hline Aritmética & & & & & \\
\hline Cancelamento & & & & 9 & \\
\hline
\end{tabular}

O quadro acima relaciona a função testada em cada subtexto, levando em consideração que o padrão médio para a idade é 10.

- Dígitos: Avalia a capacidade de armazenamento de curto prazo (recordação e repetição imediata). Representa dois elementos básicos da atenção: rapidez e spam (quantidade do sistema de processamento). PONTUAÇÃO- 5

- Sequência de números e letras: Avalia a habilidade em perceber e organizar temporalmente diferentes categorias de estímulos verbais. PONTUAÇÃO- 8

- Cubos: Avalia o componente espacial da percepção em um nível conceitual e a habilidade construtiva. Avalia a organização perceptual e visual, a conceitualização abstrata (análise do todo em suas partes componentes) e a formação de conceito não verbal e visualização espacial. PONTUAÇÃ̃o- 8

- Compreensão:Avalia o raciocínio verbal, a memória remota, o julgamento, a abstração e a flexibilidade cognitiva (avaliação e uso de experiências passadas e conhecimento dos padrões convencionais de comportamento). PONTUAÇÃO- 4

- Procurar símbolos: Avalia atenção, memória de curto prazo, rapidez de processamento, precisão, discriminação perceptual e habilidade para explorar símbolos visuais. PONTUAÇÃO- 7

- Semelhanças: Avalia as funções executivas (comparações verbais abstratas, formação de conceitos e habilidade verbal geral). PONTUAÇÃO- 5

- Vocabulário: Avalia o desenvolvimento da linguagem e o conhecimento de palavras. PONTUAÇÃO-4

- Informação: Avalia memória retrógrada, memória semântica e habilidade verbal geral (aquisição de conhecimento e retenção). PONTUAÇÃO- 5

- Raciocínio Matricial: Avalia o processamento de informações visuais e raciocínio abstrato envolvendo quatro itens: padrões contínuos e discretos, classificação, raciocínio analógico e raciocínio em série, mede o raciocínio fluido ou a habilidade de apreender conceitos não- verbais (ou seja, formas, design, padrões viso-espaciais). A inteligência fluida também é usada em tarefas onde se deve projetar uma coisa (por exemplo, peças de máquinas) para atender a certos requisitos. PONTUAÇÃo-10

- Código: Avalia o desempenho psicomotor, a atenção seletiva, a atenção sustentada, avelocidade de res posta, a organização vasomotora envolvendo velocidade e acurácia na coordenação olho o/mão e a memória visual de curto prazo. PONTUAÇÃO- 6 
- Conceitos Figurativos- Avalia o nível de abstração e habilidade de raciocinar fazendo montagens conforme uma classe específica. PONTUAÇÃO - 7

De acordo com os itens avaliados, a criança apresentou um resultado abaixo da média esperada nas áreas da atenção, comunicação, memória, linguagem e fala além da organização do pensamento que apesar de demonstrar flexibilidade, é bastante imaturo e possui poucos recursos.

A criança apresentou dificuldades na compreensão e em estabelecer relações simples entre estímulos e elaboração das respostas que são deficitariamente percebidas formando ideias e conceitos idiossincráticos.

Apesar das dificuldades importantes que devem estar ligadas ao seu comportamento extremamente infantilizado, não foram encontradas dificuldades que indiquem necessariamente uma deficiência intelectual, mas sim um atraso significativo no desenvolvimento.

Analisando os resultados do WISC IV podemos observar que o paciente obteve desempenho global compatível com a linha limítrofe apresentando média de QI 70.

Observou-se que a criança apresenta um índice compreensão verbal abaixo do esperado para a idade. Também teve desempenho prejudicado quanto à organização perceptual (que mede a capacidade de interpretar e organizar material visual e para produzir e testar hipóteses relacionadas com a resolução de problemas), embora tenha sido esse o seu melhor desempenho entre todas as funções avaliadas.

0 seu desempenho foi inferior, nos testes que medem a velocidade de processamento (que mensura a capacidade de processar o material visualmente percebido rapidamente), ficando abaixo da linha média. Deve-se observar que a criança também teve desempenho abaixo da média nos testes que medem a Memória Operacional.

Gráfico dos resultados finais da avaliação Wisc IV da 1aa avaliação

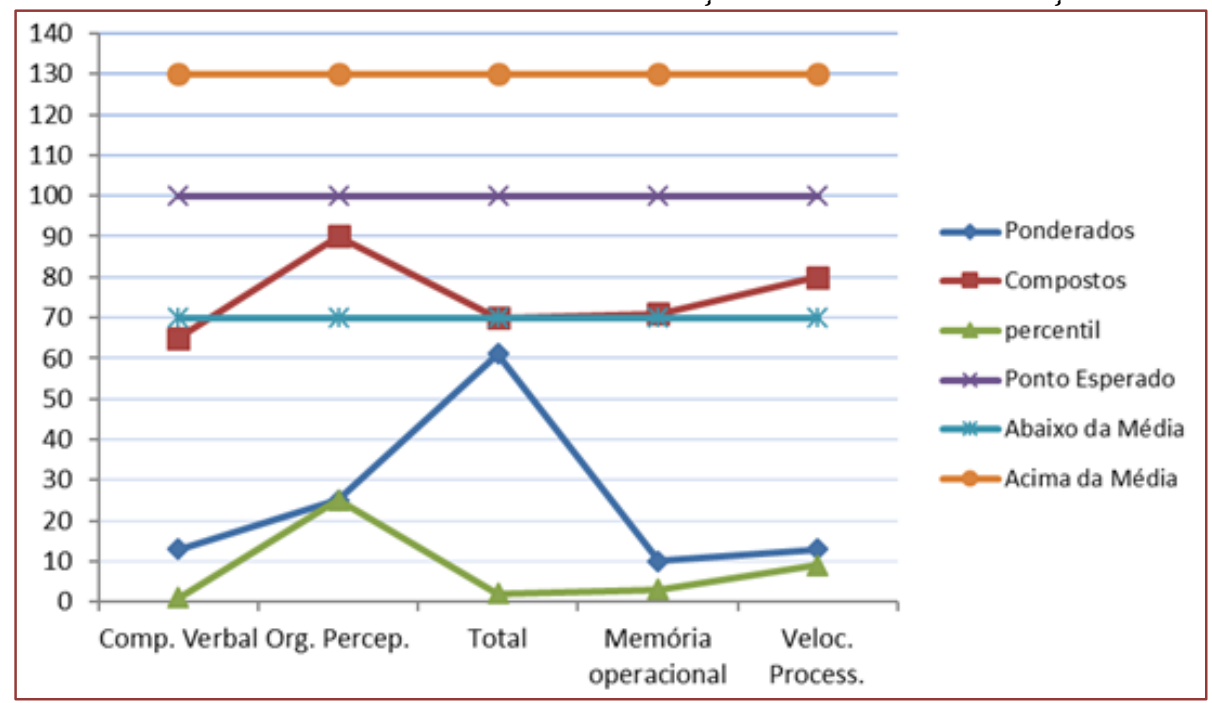

Diante dos aspectos observados, além do Distúrbio Processamento Auditivo Central, o paciente apresentou um QI 70, que o coloca na linha limítrofe e prejuízo nas funções cognitivas como, por exemplo, a dificuldade de análise e síntese, a ausência de comportamento exploratório e planejado, precariedade na elaboração. 0 analisado também apresentou uma conduta impulsiva e percepção confusa da realidade. Apresentou dificuldade na leitura e na interpretação de textos, seu discurso é desconexo e sua fala infantilizada.

A equipe multidisciplinar sugeriu o treinamento do Processamento Auditivo Central - PAC e a estimulação cognitiva pelo Programa de Enriquecimento Instrumental - PEI, que tem como objetivo para mediar a aquisição das funções cognitivas e aumentar a modificabilidade humana.

Na devolutiva com a escola foi sugerido um acompanhamento mais próximo e direcionado, que garantisse o seu acesso ao currículo. 


\section{Intervenção}

Nesta etapa foram utilizadas 50 sessões de aproximadamente uma hora, para a aplicação de algumas atividades do Programa de Enriquecimento Instrumental (PEI) e 16 sessões de Treinamento do PAC.

o Programa de Enriquecimento Instrumental é um instrumento de intervenção criado pelo neuropsicólogo Reuven Feuerstein, para aumentar a eficiência do processo de aprendizagem e corrigir as funções cognitivas deficientes.

O PEI é dividido em 7 categorias: Organização de pontos, Orientação espacial 1, Orientação espacial 2, Classificação, Comparação, Percepção analítica e Ilustração, destinados a melhorar as habilidades e estratégias cognitivas. A aplicação do programa segue uma ordem habitual de 1 sessão semanal, com 1 hora de duração. 0 aplicador apresenta os objetivos e os conteúdos e faz a mediação da aprendizagem ajudando a criança a organizar as estratégias de pensamento.

A escolha do instrumento PEI se justifica por permitir ao aplicador ou mediador utilizar-se de instrumentos cognitivos e afetivos para que as crianças desenvolvam suas competências em uma relação dinâmica, voltada para o processo e não para o resultado, no qual o diálogo tem a mesma importância do instrumento.

O treinamento do PAC foi organizado com base em estudos de diversos autores e envolveu além do treinamento auditivo, intervenções na escola e com todos os que convivem com a criança.

Os resultados obtidos podem ser vistos nos gráficos abaixo e na análise subsequente.

- Reavaliação Neuropsicológica realizada após as intervenções

Resultados da segunda avaliação nos subtestes e índices avaliados

Gráfico da Escala Weschsler de inteligência para crianças: WISC- IV

\begin{tabular}{|l|c|c|c|c|c|}
\hline \multicolumn{1}{|c|}{ CV } & \multicolumn{1}{c|}{ OP } & & & & \\
\hline Cubos & & 13 & & & \\
\hline Semelhanças & 9 & & & & \\
\hline Dígitos & & & 6 & & \\
\hline Conceitos & & 11 & & & \\
\hline Código & & & & 9 & \\
\hline Vocabulários & 6 & & & & \\
\hline SNL & & & 6 & & \\
\hline Raciocínio & & 10 & & & \\
\hline Compreensão & 10 & & & & \\
\hline Símbolos & & & & 96 & \\
\hline Figuras & & 6 & & & \\
\hline Aritmética & & & & & \\
\hline Cancelamento & & & & 10 & \\
\hline Somas ponderadas & $\mathbf{2 5}$ & $\mathbf{3 4}$ & $\mathbf{1 2}$ & $\mathbf{1 5}$ & $\mathbf{8 6}$ \\
\hline Índices convertidos & $\mathbf{9 1}$ & $\mathbf{1 0 8}$ & $\mathbf{7 7}$ & $\mathbf{8 6}$ & $\mathbf{8 9}$ \\
\hline Percentil & $\mathbf{2 1}$ & $\mathbf{7 0}$ & $\mathbf{6 6}$ & $\mathbf{1 8}$ & $\mathbf{2 3}$ \\
\hline Nível de confiança 90\% & $\mathbf{8 6 - 9 8}$ & $\mathbf{1 0 1 - 1 1 4}$ & $\mathbf{7 3 - 8 5}$ & $\mathbf{8 0 - 9 5}$ & $\mathbf{8 5 - 9 3}$ \\
\hline
\end{tabular}

Os resultados da tabela acima mostram um aumento da capacidade uma melhor desempenho das função cognitiva avaliada levando em consideração que o padrão médio para a idade é 10 . 


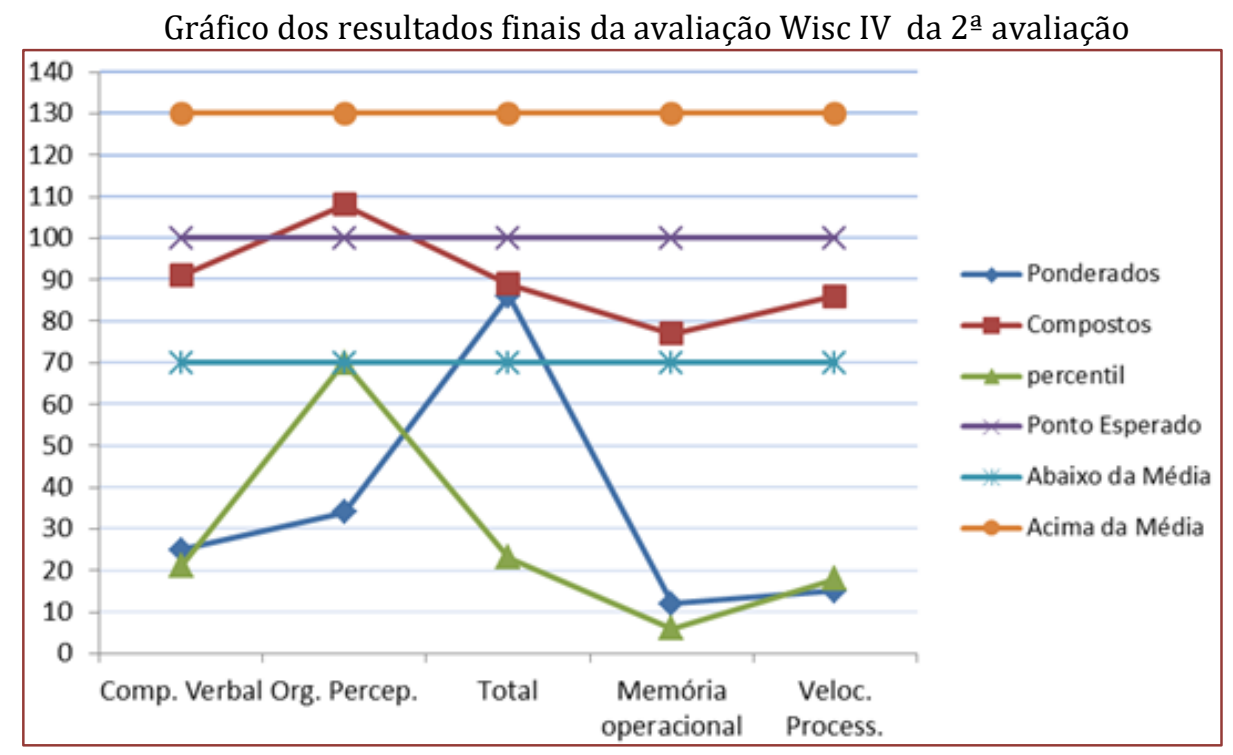

\section{Análise}

De acordo com os dados levantados na primeira e na segunda avaliação, a criança obteve um desempenho global aumentado substancialmente tendo QI total aumentado de QI T 70 para QI T 89. Apresentou um substancial desenvolvimento na compreensão verbal que estava rebaixada na primeira avaliação e na segunda aproximou-se da linha média. A criança também teve desempenho melhorado significativamente quanto à Organização Perceptual (que mede a capacidade de interpretar e organizar material visual e para produzir e testar hipóteses relacionadas com a resolução de problemas), estando acima da linha média. Em contrapartida, continua apresentando desempenho lento, com a velocidade de processamento (que mensura a capacidade de processar o material visualmente percebido rapidamente), ficando um pouco abaixo da linha média. Deve-se observar que a criança teve grande melhora no desempenho desta função, assim como houve melhora significativa (embora abaixo da média esperada) na Função Memória Operacional.

\section{CONCLUSÃO}

O trabalho multidisciplinar, envolvendo a escola os profissionais de apoio e a família, ajuda a compreender que cada sujeito, independentemente de limitações ou deficiências, é único, porque possui desenvolvimento, ritmo, características, necessidades e aprendizagens diferenciadas.

Os resultados apontam que a avaliação multidisciplinar possibilita uma melhor investigação de todos os aspectos envolvidos, evitando conclusões equivocadas, e um direcionamento mais individualizado e planejado, de acordo com as peculiaridades de cada caso.

Contrariando a ideia de que os testes serviriam para rotular a criança, na avaliação multidisciplinar a preocupação está em delimitar as dificuldades e identificar as competências pessoais, podendo assim, identificar as intervenções necessárias. Também se torna possível reavaliar a criança para identificar os resultados do trabalho, tendo assim um referencial quantitativo e qualitativo do desempenho.

O diagnóstico, nesta perspectiva, ajuda a conhecer as potencialidades da criança e investir nelas, criando estratégias de aprendizagem que permitam o acesso ao currículo. Em contrapartida, as dificuldades apresentadas no diagnóstico devem ser olhadas como um desafio à superação.

As proposições de Feurestein para o currículo escolar é que qualquer aluno independentemente de sua condição biológica, possui um potencial de aprendizagem que lhe viabiliza aprender e evoluir, desde que seja estimulado. 
Dessa forma, o olhar da escola para as potencialidades dos alunos é fundamental.

A parceria entre a família, escola e especialistas possibilita ações interventivas mais produtivas no âmbito escolar e familiar, garantindo uma maior independência e melhor desempenho acadêmico dos alunos que apresentam dificuldades escolares.

\section{REFERENCIAS}

[1] Almeida, Leandro S. Facilitar a aprendizagem: ajudar aos alunos a aprender e a pensar. Psicol. esc. educ., Campinas, v. 6, n. 2, p. 155-165, dez. 2002 Disponível em http://pepsic.bvsalud.org/scielo.php?script=sci_arttext\&pid=S1413-85572002000200006\&lng=pt\&nrm=iso>. Acessos em 04 mar. 2019.

[2] Brasil. Ministério da Educação. Secretaria de Educação Especial. Diretrizes Nacionais para a Educação Especial na Educação Básica. Brasília: Mec/Seesp, 2001.

[3] Feuerstein, R. Ontogeny of learning. In M.T.Brazier (Ed.), Brain Mechanisms in Memory and Learning. New York: Raven Press, 1979.

[4] Feuestein, R. Além da Inteligência: aprendizagem mediada e a capacidade de mudança do cérebro. RJ:Vozes, 2014.

[5] Fonseca, V. O Papel das funções cognitivas, conativas e executivas na aprendizagem: uma abordagem neuropsicopedagógica. Rev. psicopedag. vol.31 no.96 São Paulo 2014

[6] Oliveira, A.A.S. Ação avaliativa na área da deficiência intelectual: entre improvisos e incertezas. Revista Educação Especial | v. 31 | n. 63 | p. 981-994 | out./dez. 2018 Disponível em: https://periodicos.ufsm.br/educacaoeial.

[7] Royo, M.A.L. Bases Psicopedagógicas da Educação Especial. Petrópolis, RJ.: Vozes, 2012.

[8] Salami, Marcelo; Sarmento, Dirléia Fanfa. Interfaces conceituais entre os pressupostos de L. S. Vygotsky e de R. Feuerstein e suas implicações para o fazer psicopedagógico no âmbito escolar. Rev. psicopedag., São Paulo, v.28, n. 85, p. 76-84, 2011Disponível em <http://pepsic.bvsalud.org/scielo.php?script=sci_arttext\&pid=S010384862011000100008\&lng=pt\&nrm=iso>. Acessos em 04 mar. 2019.

[9] Samelli, A. G. Treinamento Auditivo para Transtorno do Processamento Auditivo: uma proposta de intervenção terapêutica. Cefac. São Paulo,2009. Disponível em : http://www.scielo.br/pdf/rcefac/2010nahead/1709.pdf acesso em 2009.

[10] Wechsler, D. (1991). Wechsler Intelligence Scale for Children- 3aㅡ ed. (WISC-III): Manual. San Antonio, TX: Psychological Corporation.

[11] Wechsler, D. (2002). Wisc-III- Escalas de Inteligência Wechsler para crianças- 3a ed. Adaptação e Padronização de uma amostra brasileira: Vera Lúcia Marques de Figueiredo. São Paulo, SP: Casa do Psicólogo.

[12] Wechsler, D. (2013). Escala Weschsler de inteligência para crianças: WISC- IV. Manual Técnico. Tradução do manual original Maria de Lourdes Duprat. (4. ed.). São Paulo: Casa do Psicólogo. 


\section{Capítulo 15}

\section{A sala de atendimento educacional especializado-AEE no desenvolvimento dos alunos com deficiência}

\section{Ana Paula Silva de Souza}

Genilda Mendonça de Souza Araújo

Márcia Gomes dos Santos Silva

Mônica de Fátima Guedes de Oliveira

Resumo: Este artigo tem com objetivo apresentar as Contribuições do Atendimento Educacional Especializado-AEE no desenvolvimento dos alunos com deficiência no Ensino Regular, desafios e perspectivas. Este trabalho está embasado com as leis e decretos que regem o AEE em nosso país e em autores que estudam o tema, tais como Gomes (2007), Ramos (2012), Santos (1999), Sartoretto (2010), Mantoan (2003), Figueira (2011) Correia (1999) dentre outros. 0 método utilizado foi o de pesquisa qualitativa de observação e vivência no espaço escola em que abordou a prática embasada nas teorias. 0 resultado do trabalho se concentra em reafirma a seguridade dos documentos oficiais onde se propõem a importância de fazer adequações aos métodos de ensino de maneira a eliminar barreiras que possivelmente estejam atrapalhando o desempenho escolar dos alunos com deficiência como também apresenta o trabalho realizado pelo professor do Atendimento Educacional Especializado por meio de anamneses, planejamento, produção de materiais, adequação de atividades e estratégias diversificadas.

Palavras-chave: Atendimento Educacional Especializado. Inclusão. Professor do AEE. Ensino Regular. 


\section{INTRODUÇÃO}

O tema inclusão é bastante abordado e debatido nos mais variados meios principalmente em eventos educacionais seja na esfera Municipal, Estadual ou Federal, especialmente no ambiente escolar, por se tratar de um tema importante e ao mesmo tempo complexo o que afligi diariamente os professores da sala regular. Por meio disso os debates têm ganhado cada vez mais proporções de estudos, busca de estratégias que de fato possa contribuir de forma relevante para a compreensão e o conhecimento dos profissionais do ensino de tal modo que os alunos com deficiência tenha o direito a um ensino com currículo e atividades adaptadas a suas peculiaridades em condições de igualdade para seu pleno desenvolvimento intelectual, físico, psíquico e social que de tal forma continuem aprendendo das mais diversas maneiras.

Este artigo tem como finalidade discorrer acerca das dificuldades e desafios enfrentados pelo professor do Atendimento Educacional Especializado-AEE na realização de suas as atividades cotidianas um exemplo dessas dificuldades é o contato como os professores do ensino regular, especialmente dos encaminhados de escolas adjacente, mais também apontar os benefícios que o trabalho realizado propõe aos educandos com deficiência no seu desenvolvimento acadêmico e social.

Para fundamentar teoricamente foram citados autores que prismam pelo processo educacional e se reportam de maneira clara e coerente com o que se vivencia no ambiente escolar e o que ainda é preciso refletir para melhorar o processo de ensino nas instituições públicas, seja ela Municipal, Estadual ou até mesmo Federal. Autores como Ribeiro (2003), Nunes (2019), Santos (2003), Santos (2017), Mantoan (2003), Figueira (2011), Lima (2016) e Paulo Freire (1987) foram autores citados dentro desse contexto da Educação Especial voltado para o Atendimento Educacional Especializado e sua oferta na Sala de Recurso Multifuncional, assim como os documentos oficiais. 0 texto decorre apontando desafios que os professores dos dois serviços sofrem, mais também perspectivas de melhoras que no decorrer dos anos vem acontecendo, a passos lentos mais que já faz uma diferença enorme no contexto educacional e para vida da pessoa com deficiência.

No desenvolver se descrever o que de fato é a de Sala de Recurso Multifuncional que hoje comumente é mais conhecido com Atendimento Educacional Especializado (AEE) e sua implantação como ocorreu, decretos que assegura esta "novidade" no cenário educacional, que ano aconteceu e o que se realiza durante a aula/atendimento. Nós pontuamos alguns desafios pelo quais o professor do AEE vivencia constantemente que vai desde barreiras arquitetônica há barreiras físicas que se direciona a falta de contato com o professor do ensino regular, onde de fato ambos necessitam trabalhar de forma integrada de modo realizar conjuntamente meios de sanar dificuldades essenciais. Toda via em meio a tais barreiras existenciais é inegável que o aluno que frequenta o AEE tem um desempenho significativo no seu processo de formação e aprendizagem, eu enquanto professora atuante no AEE, vejo quão é nítido e válido o desenvolver de atividades pensadas e voltadas para superar dificuldades apresentadas em sua vida escolar mais também social.

\section{METODOLOGIA}

A metodologia utilizada neste trabalho foi a pesquisa qualitativa de observação e vivência no espaço escolar, um olha direcionado para as contribuições que o Atendimento Educacional Especializado proporciona aos alunos com deficiência no seu desenvolvimento escolar, assim como apontar os desafios que os professores enfrentam diariamente para que ocorra um processo de inclusão colaborativo.

Por meio desse trabalho podemos enfatizar ação dinâmica que ocorre no AEE, pois é desenvolvido atividades diversificadas com intuito de garantir da melhor maneira possível a aprendizagem e o desenvolvimento dos educandos, mais que também há falta de compromisso de algumas famílias para como o trabalho realizado, e em alguns caso excepcionais se dar por causa do pensamento em recebimento do BPC (Benefício de Prestação Continuada) e diante desse fator se omitem em levar o aluno para as aulas como medo do filho avançar nos campos cognitivos e perder o benefício, por isso em alguns caso o professor do AEE retira o aluno da sala regular para poder aplicar seu trabalho para com o mesmo, pois há uma grande parcela de pais que não leva no turno oposto.

\section{A SALA DE RECURSO}

A sala de recurso é um ambiente ofertado preferencialmente na rede regular de ensino para o intuito de trabalhar habilidades nos educandos com deficiência que possibilite seu desenvolvimento social e escolar usando recursos de acessibilidade e materiais pedagógicos que auxiliaram sem dúvida na promoção da 
escolarização, eliminando barreiras que impedeçam sua plena participação, com a autonomia e independência, no ambiente educacional e social. Os estudantes público alvo da educação especial deve estar matriculado nas classes comuns, em uma das etapas, níveis ou modalidades da educação básica, sendo o AEE ofertado no turno oposto ao do ensino regular. A Sala de Recurso Multifuncional tem papel fundamental na criação de estratégias que são necessárias a adaptação da pessoa com deficiência, respeitando sempre a individualidade de cada aluno e suas necessidades específicas.

O Atendimento Educacional Especializado decorre de uma nova concepção da Educação Especial, sustentada legalmente, e é uma das condições para o sucesso da inclusão escolar dos alunos com deficiência. Esse atendimento existe para que os alunos possam aprender o que é diferente dos conteúdos curriculares do ensino comum e que é necessário para que possam ultrapassar as barreiras impostas pela deficiência (BRASIL, 2007, p.22).

Ou seja, temos no Atendimento Educacional Especializado, mais precisamente, na Sala de Recurso Multifuncional, um ambiente que servi de preparo para que o aluno com deficiência desenvolva habilidades, e de tal maneira consiga acompanhar a rotina da classe regular, mas também que aprenda coisas e vivencie situações que façam sentido para seu próprio universo, possibilitando uma aprendizagem voltada ao individual e não generalista, atendendo ao currículo demandado aos demais alunos do regular.

Aos gestores dos sistemas de ensino cabe definir quanto à implantação das salas de recursos multifuncionais, o planejamento da oferta do AEE e a indicação das escolas a serem contempladas, conforme as demandas da rede, para isso devem atender os seguintes critérios do Programa: A secretaria de educação a qual se vincula a escola deve ter elaborado o Plano de Ações Articuladas (PAR), registrando as demandas do sistema de ensino com base no diagnóstico da realidade educacional; A escola indicada deve ser da rede pública de ensino regular, conforme registro no Censo Escolar MEC/INEP (escola comum); A escola de ensino regular deve ter matrícula de aluno(s) público alvo da educação especial em classe comum, registrado(s) no Censo Escolar/INEP, para a implantação da sala Tipo I; E as escola de ensino regular que tem matrícula de aluno(s) cego(s) em classe comum, registrado(s) no Censo Escolar/INEP, recebem a implantação da sala de Tipo II; A escola deve ter disponibilidade de espaço físico para o funcionamento da sala e professor para atuação no AEE.

A Secretaria de Educação efetua a adesão, o cadastro e a indicação das escolas contempladas por meio do Programa no Sistema de Gestão Tecnológica do Ministério da Educação - SIGETEC, No ato de solicitação das salas, as secretarias de educação assumem o compromisso com os objetivos do Programa e realizam no SIGETEC os seguintes passos: adesão e cadastro do gestor do Município (Prefeito), Estado ou Distrito Federal (Secretário de Educação); Indicação das escolas conforme os critérios do Programa; Confirmação de espaço físico para a sala; Confirmação de professor para atuar no AEE. Após essa demanda os mesmos têm o deve de informar, monitorar, orientar, acompanha o trabalho desenvolvido assim como apoiar a participação dos professores nos cursos de formação para o AEE.

\subsection{DESAFIOS DA EDUCAÇ̃̃O E O PROFESSOR DA SALA MULTIFUNCIONAL}

Os desafios enfrentados para que a inclusão ocorra e cumpra seu papel são diversos e de maneira sucinta pode-se dizer que a eliminação das barreiras físicas e arquitetônicas são sem dúvida algo que pendura desde seu processo de surgimento, a necessidade e oferta de formação sistemática para os professores, e também demais funcionários da instituição de ensino, que atendem o público alvo da educação especial mais também inclusiva, a falta de comprometimento de algumas famílias, isso tudo é algo que aflige os profissionais mais também a família dos educandos, as dificuldades de saber recepcionar e saber como iniciar um trabalho de maneira a abonar as barreiras e peculiaridades que as deficiências apresentam são sem dúvida algo que dificultam muito.

O diz que:

A escola regular de qualquer nível ou modalidade de ensino, ao viabilizar a inclusão de alunos com necessidades especiais, deverá promover a organização de classes comuns e de serviços de apoio pedagógico especializado. Extraordinariamente, poderá promover a organização de classes especiais, para atendimento em caráter transitório. (RIBEIRO; BAUMEL, 2003, p.165).

Pois bem, o ensino se faz essencial para todo e qualquer indivíduo, seja ele com ou sem deficiência e a escola é o ambiente indispensável para promover o acesso ao conhecimento, a adequação de atividades 
necessária para a realidade de seu aluno, hoje não se admitir mais que a escola na pessoa do professor haja de maneira aquém a toda mudança que estamos vivenciados referente a inclusão do deficiente.

Na Lei Brasileira de Inclusão no Capitulo IV trata especificamente da educação e deixa bem explícito o direito que a pessoa com deficiência tem ao acesso no sistema educacional como também a propostas de adequação de planos e atividades que atenda as especificidades do educando sem que haja nenhuma forma de discriminação (BRASIL, 2015). Vejamos o que diz na LBI, cap. IV, art. 27:

A educação constitui direito da pessoa com deficiência, assegurados sistema educacional inclusivo em todos os níveis e aprendizado ao longo de toda a vida, de forma a alcançar o máximo desenvolvimento possível de seus talentos e habilidades físicas, sensoriais, intelectuais e sociais, segundo suas características, interesses e necessidades de aprendizagem. (BRASIL, 2015, p.1).

O professor da AEE sem sobra de dúvida lida com a barreira chamada falta de o contato com o professor do ensino regular, um planejamento específico e direto com os professores que estão diariamente com o aluno, acompanhando todas as peculiaridades que o mesmo apresenta.

Essa limitação se dar por conta da vida sobrecarregada que o profissional enfrenta, é muito comum muitos educadores no contra turno estarem em escolas distintas e o momento de contato para uma troca de ideias e sugestões as vezes pode acontecer de maneira breve em planejamentos que ocorrem para abordagem e resoluções de temais diversos, ou seja a aproximação entre esses professores torna-se um dos maiores desafios que a modalidade do ensino passa, outro ponto a ser exposto é assiduidade de uma parcela considerada dos alunos com deficiência, pois muitos tem um roteiro de atividades intenso e também a questão de locomoção para chegar até a escola de oferta do AEE porque as escolas que tem esse serviço são em minoria, infelizmente.

Outro entrave encontrado é a defasagem de recursos e assistência por parte dos gestores na esfera Municipal assim como infelizmente não há de fato um olhar mais direto e com preocupação efetiva em solucionar em tempo hábil os problemas de acessibilidade arquitetônica, materiais didáticos pedagógicos, atraso no iniciar das atividades da Sala de Recurso que só se inicia após aproximadamente um mês depois do início das aulas do ensino regular.

Há ainda muito o que enfrentar para que essa modalidade do ensino torne-se algo muito além do que hoje é, falta por parte de algumas famílias o comprometimento de levarem ao atendimento de forma assídua sem interrupções no desenvolver das atividades realizadas pelo professor no AEE, a indignação ainda é recorrente por que ainda nos deparamos com a falta de empatia e interesse de alguns profissionais que tira de sim a responsabilidade acerca do aluno com deficiência e transfere para o outro causando desmotivação, e desinteresse dos educando e de seus pais, com isso o profissional do AEE tenta combater e lança sempre ideias de positivismo mostrando os avanços atingidos que cada um é capaz, assim como dicas de que necessita fazer para continuar com o desempenho.

É, o processo inclusivo enfrenta este e outros desafios constantemente, pois muitos acreditam que o ensino escolar se dar apenas individualizado, sem nenhuma precaução com o diferente e que a responsabilidade é apenas de um professor, aquele em especial que atua no AEE e não se tocar da necessidade que se tem em criar parcerias como pais, professores e profissionais que atende o aluno.

\subsection{UM OLHAR PARA O ATENDIMENTO EDUCACIONAL ESPECIALIZADO (AEE)}

O Atendimento Educacional Especializado-AEE é uma modalidade de ensino que veio para ajudar no desenvolvimento escolar e social dos alunos deficientes que estão no processo de ensino aprendizagem nas escolas públicas Municipais/ Estaduais assegurados em todas as etapas e modalidades da educação básica, o mesmo é organizado para apoiar o desenvolvimento dos alunos, constituindo oferta obrigatória dos sistemas de ensino e o atendimento deve ser realizado no turno inverso ao da classe comum, na própria escola ou em outra que tenha estrutura e a oferta, assim como em centro especializado que realize esse serviço educacional.

Em Sapé-PB existem apenas três instituições de ensino que dispõem da oferta do AEE, onde as demais unidades se subdividir de acordo com a proximidade que melhor for para os pais levarem seus filhos, atendemos alunos com Deficiência Intelectual (maior demanda), Auditiva, Física e TEA (Transtorno do Espectro Autista) que está de acordo com As Diretrizes Operacional da Educação Especial para o Atendimento Educacional Especializado na Educação Básica onde considera-se público-alvo do AEE: a. Alunos com deficiência: aqueles que têm impedimentos de longo prazo de natureza física, intelectual, 
mental ou sensorial, os quais, em interação com diversas barreiras, podem obstruir sua participação plena e efetiva na sociedade em igualdade de condições com as demais pessoas. b. Alunos com transtornos globais do desenvolvimento: aqueles que apresentam um quadro de alterações no desenvolvimento neuropsicomotor, comprometimento nas relações sociais, na comunicação ou estereotipias motoras. Incluem-se nessa definição alunos com autismo clássico, síndrome de Asperger, síndrome de Rett, transtorno desintegrativo da infância (psicoses) e transtornos invasivos sem outra especificação. c. Alunos com altas habilidades/superdotação: aqueles que apresentam um potencial elevado e grande envolvimento com as áreas do conhecimento humano, isoladas ou combinadas: intelectual, acadêmica, liderança, psicomotora, artes e criatividade.

O AEE é de suma importância porque trabalha as reais necessidades do aluno, de acordo com seu ritmo de aprendizagem e suas peculiaridades individuais, de maneira que os alunos possa desenvolver sua autonomia, desprendimento, aprendizagem, facilitando também a aquisição de seus valores, além de favorecer a compreensão de conhecimentos relacionados à aplicação de situações de vida cotidiana, contribuindo assim para o desenvolvimento das potencialidades de cada aluno proporcionando a aquisição de habilidades inter e intrapessoais, contribuindo para que o aluno construa gradualmente os seus conhecimentos, pelos processos de avanços e recuos inerentes ao seu próprio ritmo, evoluindo a cada passo. Assim o AEE é

uma modalidade de ensino que perpassa todos os níveis, graus e etapas do percurso escolar e tem como objetivos, entre outros, identificar as necessidades e possibilidades do aluno com deficiência, elaborar planos de atendimento, visando ao acesso e à participação no processo de escolarização em escolas comuns, atender o aluno com deficiências no turno oposto àquele em que ele frequenta a sala comum, produzir e/ou indicar materiais e recursos didáticos que garantam a acessibilidade do aluno com deficiência aos conteúdos curriculares, acompanhar o uso desses recursos em sala de aula, verificando sua funcionalidade, sua aplicabilidade e a necessidade de eventuais ajustes, e orientar as famílias e professores quanto aos recursos utilizados pelo aluno. (SARTORETTO, 2010, p 2).

Como afirma Sartoreto (2010) o AEE é a etapa que está dentro de todas as demais, porém com uma função social enorme em trabalhar para que o aluno com deficiência possa vencer barreiras que o limita na sua vida escolar.

Em Sapé há um engajamento para atender a demanda expressada pelos professores que estão 4 horas por dia com o aluno, todos os dias da semana. No início do ano letivo a secretaria de educação Municipal solicita um levantamento dos alunos com deficiência matriculados nas instituições, indicando a deficiência apresentada e série a qual está matriculado no corrente ano letivo, solicita também em nome da coordenação de Educação Especial que os professores preencham um ficha de encaminhamento em que registre as dificuldades e características apresentadas durante a aula relacionadas a aprendizagem e socialização de seu aluno deficiente, este encaminhamento é destinado para o professor(a) do AEE de seu polo de apoio.

O objetivo é compreender o que de mais agravante o professor do ensino regular sente em relação a trabalhar com o aluno e diante desse fator o professor do AEE, elabora um plano de trabalho que atendar as necessidades apontadas e também que o mesmo percebeu.

O professor do AEE ao receber os encaminhamentos preenchidos pelos professores do ensino regular faz um estudo, entra em contato com os pais para preencher a anamnese acerca de cotidiano familiar e também atendimento multidisciplinar (médicos, fonoaudiólogos, FUNAD, CAPSi etc.), seguindo os protocolos marca se reunião com todos os pais para mostrar a proposta de trabalha do corrente ano. A dinâmica de trabalho ocorre em organizar os alunos de acordo com as necessidades relatadas pelos pais e professor em que dependendo do caso há agrupamentos de até 5 alunos e há outros casos que a necessidade é individualizada mediante isso a função do professor do AEE é o de identificar, elaborar e organizar recursos pedagógicos e de acessibilidade que eliminem as barreiras para a plena participação dos alunos, considerando suas necessidades específicas.

Aceitar trabalhar em uma Sala de Recursos Multifuncionais é deparar-se com a inovação.

Inovar não tem necessariamente o sentido do inusitado. As grandes inovações estão, muitas vezes na concretização do óbvio, do simples, do que é possível fazer, mas que precisa ser desvelado, para que possa ser compreendido por 
todos e aceito sem outras resistências, senão aquelas que dão brilho e vigor ao debate das novidades. (MANTOAN, 2003, p.81).

Realmente a inovação, a criatividade e empatia precisam estarem juntas em todos os momentos, principalmente quando você é professora da Educação Especial, pois lida com pessoas que em seu histórico de vida carregam enormes dificuldades desde sua estrutura familiar como também social, é impossível não destacar a inclusão como algo que muito tem tido avanços em todos os contextos, muitas batalhas vencidas, mais também inúmeras barreiras ainda a serem superadas, recentemente em 2015 foi publicada a Lei 13.146 Lei Brasileira de Inclusão documento que traz justamente abordagem e segurança em efeito de lei especificando a sua plena efetivação sem mais ou menos, forma de reafirma ainda mais o que os demais documentos norteadores traziam. Esta lei engloba diversos aspectos que envolvem desde as de vida cotidiana das pessoas com deficiência como sobre os mais variados direitos, tais quais: acessibilidade e educação reforçando direitos que já existiam em outras leis com: Constituição Federal, LDB, ECA, etc. (BRASIL, 2015).

Através das experiências inovadoras e dos desafios que se apresentaram no decorrer do percurso de minha prática pedagógica, observo quão grande importância de realizar um trabalho de cunho claro, dinâmico e planejado de modo a contribuir para obter uma educação especial de qualidade a partir de um atendimento especializado.

Desenvolver um bom trabalho requer muita empatia, paciência e perseverança, pois cada aluno é único independente de ter a mesma deficiência descrita em laudo médico com mesmo Cid ( Classificação Internacional de Doença) mais suas ações e reações se difere, seu processo de ensino e aprendizagem é diferente, as habilidades em muitos dos casos se distancia bastante um do outro e ai é pontual a destreza e o conhecimento que o professor precisa ter para conduzir uma proposta de trabalho a que longo, médio ou curto prazo terá resultados positivos. No caso do aluno com Deficiência Intelectual suas acentuadas dificuldades se dar no processo de aquisição da leitura, escrita, memória e racíocinio matemático para isso é elaborado um plano individual para cada um que apresenta esta deficiência, fazendo uso de uma dinâmica pedagógia lúdica e com recurso concreto para facilitar e mediar o processo de aquisição do conhecimento; Alunos com Deficiência Auditiva precisam de atividades que expresse sua comunicação através da Língua Brasileira de Comunicação assim com um adaptação de atividades e recursos que tragam explicitas a Libras, que de fato é sua língua materna de modo a sempre aprimora-la; Os alunos com Paralisia Cerebral (classificamos com D.Física) precisa de um trabalho que estimule a coordenação motora fina/ampla e viso-motora, memória, linguagem e dentre outras que se percebe e que estejam de acordo com as atribuições do AEE; O Autismo é um das deficiência que no ambiente escolar vai precisar de muitas adaptações como por exemplo comunicativa e social, se elabora pranchas para comunicação alternativa com AVDs (atividade de vida diárias), atividade para a coordenação motora, memória, estímulos sonoros, escrita, leitura, etc. Todas as situações vai depender de cada caso de autista seguindo do nível mais leve ao severo; no que diz respeito ao Deficiente Visual as atividades se focam no ensino do Sistema Braille mais também em trabalhos de estímulos aos demais sentidos e a sua autonomia de mobilidade no ambiente escolar.

O aprender com Paulo Freire (1987) afirma é aprende com as diferenças, no AEE procuramos sempre dar o melhor para que o aluno possa ter uma aprendizagem qualitativa de maneira a aflorar no seu contexto diário e no ensino regular, a aprendizagem dentro da sua maneira, pois cada um tem seu jeito de codificar as informações dadas. É dever do professor especialista fazer m estudo de caso para melhor entender as peculiaridades e assim elabora o PDI (Plano de Desenvolvimento Individual) que atendar as necessidades que o aluno com deficiência apresenta. Diante ao trabalho desenvolvido é perceptível a evolução que os educandos apresentam em seu aprendizado tanto em aspectos básico de leitura e escrita como também em fatores de socialização e autonomia, é um trabalho minucioso e o efeito acontece em detalhes que transborda na vivencia do mesmo.

Para Figueira (2011, p.47),

A Escola não é algo acabado, estático. Como todo segmento da sociedade, tem que estar em constante transformação, revendo suas ações pedagógicas, adaptando-se aos novos tempos para sempre somar e nunca excluir. Uma Escola realmente plural precisa ser um espaço comum de cidadania, livre exercício político e espaço público de manifestações das diferenças, incorporando todos os valores sem promover hierarquias.

Como Figueira (2011) retrata a Escola deve ser o ambiente que promova uma mudança de paradigmas, se mova em um sentido de propagar e respeitar as diferenças. 
Diante do que foi exposto podemos constatar que o professor da sala AEE contribui de forma significativa com a integração, inclusão e aprendizagem dos alunos com deficiência, quando o seu principal objetivo é o processo de aprendizagem do ser humano. Por tudo que aqui foi exposto, entendemos que a prática pedagógica de forma inclusiva precisa ser mais unificada, repensada e flexível para que realmente ocorra um trabalho mais unificado e que elimine as barreiras arquitetônicas, mais também social, levando em conta que cada ser humano tem um estilo de aprender diferente, isto é, somos seres heterogêneos e estamos diretamente ligados ao meio em que vivemos como também a comunidade a que pertencemos.

\section{CONCLUSÃO}

Através dessa pesquisa, podemos conhecer sobre as contribuições do trabalho do Atendimento Educacional Especializado para o aprendizado dos alunos deficiente na rede pública de ensino da cidade de Sapé, apontando como se direciona as atividades pedagógicas de modo a ajudar no processo de escolarização dos alunos com deficiência na Sala de Ensino Comum.

Através da vivencia no AEE, podemos perceber que na sala tem um acervo considerável de materiais, porém muitos desses materiais estão desgastados e não atende mais as dificuldades apresentadas pelos alunos. Nesse contexto de falta de material didático pedagógico para realizar atividades direcionada a dificuldade apresentada pelo aluno seja auditivo, cego, TGD (Transtornos Globais do Desenvolvimento) intelectual, autista, ou com Altas Habilidades/Superdotação fica sobre responsabilidade e atribuições do professor do AEE planejar, elaborar e confeccionar materiais que objetivem o desenvolvimento diante da necessidade apresentada. Percebeu-se também que não existe uma relação entre o professor do ensino regular e o professor do AEE para discutir as dificuldades dos alunos de forma que possa melhorar quantitativamente a aprendizagem dos educandos.

Sendo que é necessária uma formação continuada para os professores, podendo contribuir de maneira positiva e significativa na relação e aproximação com o profissional do AEE. Por meio de observação e vivencia podemos constatar que a sala do AEE mesmo tendo alguns recursos eles não são suficientes, levando em consideração cada deficiência, que o diálogo e planejamento professor Especialista e as professoras do Ensino Regular não ocorre com deveria acontecer de maneira a desenvolver metodologias mais adequadas às particularidades dos alunos. Quanto à estrutura da escola, a mesma possui características de acessibilidade, pois possui rampa e corrimão, para o público que frequenta, porém necessita de uma equipe multidisciplinar que atendar as necessidades existente no âmbito.

Enfim, podemos concluir que o ensino da Pessoa com Deficiência não acontece apenas colocando o aluno dentro da escola, ou seja, é necessário que aconteça todo um trabalho em equipe de maneira que ele seja recebido com respeito e sensibilização de causa, e o trabalho seja executado abordando suas peculiaridades para tanto é importante a presença da sala de AEE que apresente um trabalho diferenciado para realmente surtir os resultados esperados. Em outras palavras, é no ambiente da sala de AEE que vai ser trabalhado todas as dificuldades dos alunos deficientes e terá o objetivo de fazer com que aconteçam mudanças positivas durante o processo de aprendizagem na escolarização desses aprendentes.

\section{REFERÊNCIAS}

[1] Baia, Ineide Ferreira. O atendimento educacional especializado e as práticas educativas na perspectiva da inclusão na Escola Maria Rafols de Breves-PA. Especialização em educação especial e inclusiva, 2015. Disponível em: https://monografias.brasilescola.uol.com.br/educacao/o-atendimento-educacional-especializado-as-praticaseducativas-na-perspectiva-da-inclusao.htm\%2024/03/2019\%20as\%2020:20 Acesso em: 25 fev.2019.

[2] Brasil. Atendimento Educacional Especializado. Deficiência Mental. São Paulo: Mec/SEESP, 2007.

[3] Brasil. Decreto no 6571. Brasília, 2008.

[4] Brasil. Lei no 13.146, de 6 de julho de 2015. Institui a Lei Brasileira de Inclusão da Pessoa com Deficiência (Estatuto da Pessoa com Deficiência). Brasília, 2015.

[5] Brasil. Ministério da Educação. Lei de Diretrizes e Bases da Educação Nacional (Lei 9394/96), Brasília, 1996.

[6] Brasil. Ministério da Educação. Secretaria de Educação Especial. Decreto no 5.626, de 22 de dezembro de 2005. Regulamenta a Lei № 10.436, de 24 de abril de 2002 .

[7] Brasil. Resolução CNE/CEB no 2, de 11 de setembro de 2001. Diretrizes Nacionais para a Educação Especial na Educação Básica. 
[8] Educação Especial. Implantação das Salas de Recursos Multifuncionais. 2012. Disponível em: https://especialdeadamantina.wordpress.com/2012/11/12/implantacao-das-salas-de-recursos-multifuncionais/ Acesso em: 25 fev.2019.

[9] Figueira, E. A educação Inclusiva é o grande desafio do século XXI. In: Jornal O Globo. Caderno de Educação, Rio de Janeiro, em 24/06//2011. Disponível em: http://emiliofigueira.com/wp-content/uploads/2018/01/EmilioFigueira-Entrevistas-E-Artigos.pdf Acesso em: 30 mar. 2019

[10] Freire, Paulo. Pedagogia do Oprimido. 17. ed. Rio de Janeiro: Paz e Terra, 1987.

[11] Lima, Ananeri Vieira de; Carneiro, Ana Paula Lima. A importância da sala de atendimento educacional especializado - AEE. [Anais]. II Cintedi Congresso Internacional de educação inclusiva 16 a 18 de nov. 2016. Disponível em:https://editorarealize.com.br/revistas/cintedi/trabalhos/Trabalho_EV060_Md1_SA6_Id4216_23102016232252.p df Acesso em: 05 abr.2019.

[12] Macedo, Francisca Hilderlene Gonçalves de Oliveira. Contribuições do AEE no desenvolvimento escolar de três alunos NEE do ensino fundamental I, em uma escola municipal em Porto Nacional - TO. 2016. 47 f. Monografia (Especialização em Desenvolvimento Humano, Educação e Inclusão Escolar) - Universidade de Brasília, Universidade Aberta do Brasil, Porto Nacional-T0, 2015. Disponível em: http://bdm.unb.br/handle/10483/15723 Acesso em: 01 maio 2019.

[13] Mantoan, Maria Tereza Eglér. Todas as crianças são bem-vindas à escola. Universidade Estadual de Campinas / Unicamp Laboratório de Estudos e Pesquisas em Ensino e Reabilitação de Pessoas com Deficiência - Leped/ Fe/ Unicamp 1999. 2003.

[14] Nunes, Anna Paula de Paiva; Freitas, Polianny Ágne de. A importância e o papel do atendimento educacional especializado (AEE) e do auxiliar na educação de crianças com deficiência. [Anais] II Seminário Potiguar. Disponível em: http://www.uern.br/controledepaginas/edicao-atual/arquivos/36784_artigo_ii_semina\%C2\%A1rio_potiguar_(polianny_e_anna_paula).pdf Acesso em: 05 abr. 2019.

[15] Ribeiro, Maria Luísa Sprovieri; Baumel, Roseli Cecília Rocha de Carvalho. Educação Especial: do querer ao fazer. São Paulo: Avercamp, 2003.

[16] Santos, Euzimar Gregório dos. Educar na adversidade. João Pessoa: Libellus, 2017.

[17] Santos, Layla do Carmo Cruz dos. A Sala de Recursos Multifuncionais e seu papel na inclusão de crianças com Transtorno do Espectro Autista. Monografia (Licenciatura em Pedagogia) - Faculdade de Educação da Ufrj, Rio de Janeiro, 2017. Disponível em: https://pantheon.ufrj.br/bitstream/11422/2190/1/LCCSantos.pdf Acesso em: 23 mar. 2019. 


\section{Capítulo 16}

\section{Deficiência intelectual e aprendizagem: Estudos sobre inclusão no município de Ipojuca}

\section{Maria Rosemary de Brito \\ Edna Felix da Silva \\ Geany Carla Barros Silva \\ Kaltieli Gomes da Silva}

Resumo: 0 proposito deste trabalho é apresentar a temática de pessoas com deficiência intelectual no processo de desenvolvimento da aprendizagem; escolar de crianças e adolescente com deficiência intelectual que estudam na escola Municipal Santo Cristo Ipojuca - PE. Através de um rastreamento histórico da educação no contexto que nós estamos vivenciando nesse século XXI constatamos que Educação Especial é um grande avanço na sociedade brasileira, despontando com proposta educacionais inovadoras em prol das pessoas com deficiência intelectual e com novas abordagens e conceitos, tendo como consequência a reformulação cultura que conduz a integração na escola dos chamados excluídos. Onde a inclusão de alunos com necessidades educacionais especiais tem de um modo geral, aumentado gradativamente no sistema público brasileiro. Com um processo ensino-aprendizagem voltado a construção da cidadania ligado a uma prática pedagógica, que considere o respeito, as diferenças e 0 atendimento às necessidades individuais enquanto princípio de equidade.

Palavras-chave: Deficiência intelectual. Inclusão. Educação. Aprendizagem 


\section{INTRODUÇÃO}

Com base no conceito do tema, na visão de consagrados autores da atualidade: Almeida (2011), Vygotsky (1896-1934), Mazzotta (2005), Montoan (1997), Canguilhem (1965), entre outros grandes pensadores da educação, percebeu-se eles são contraditores aos pensadores da antiguidade que defendiam a teoria de que, a inserção das pessoas com deficiência intelectual era considerada uma ameaça à sociedade, porém, a perspectiva de inclusão proporcionava ao indivíduo com deficiência intelectual, a possibilidade de aprender e tornar-se melhor através do trabalho em grupo no ambiente escolar, buscando melhor prepara-los para a vida adulta em uma sociedade.

Ao longo do artigo propõe-se uma reflexão sobre as dificuldades encontradas pelas pessoas com deficiência intelectual no que diz respeito aos processos de ensino e aprendizagem.

Palavras-chave: Deficiência intelectual. Inclusão. Educação. Aprendizagem

\section{METODOLOGIA}

Este artigo compõe da dissertação de mestrado, é um subprojeto com propósito de compreender o processo de aprendizagem de crianças e adolescentes deficientes intelectuais. Para tal compreensão, fundamentou-se em análises bibliográficas. Trata-se de uma pesquisa qualitativa, dirigida à família, professores da educação especial e do ensino regular. Selecionou-se uma escola do município de Ipojuca que trabalha com alunos com deficiência intelectual comprovada. Usou-se um instrumento de investigação com questões abertas onde profissionais e familiares de crianças com Deficiência Intelectual responderam para entender como é realizada a inclusão destes alunos, conforme citaram Minayo e Deslandes (2002), buscar a compreensão ou explicação em profundidade dos valores, práticas, lógicas de ação, hábitos e atitudes, responde a questões muito particulares. Ela se ocupa, nas Ciências Sociais, com um nível de realidade que não pode ou não deveria ser quantificado. Ou seja, ela trabalha com o universo dos significados, dos motivos, das aspirações, das crenças, dos valores e das atitudes. Esse conjunto de fenômenos humanos é entendido como parte da realidade social, pois o ser humano se distingue não só por agir, mas pensar sobre o que faz e por interpretar suas ações dentro e a partir da realidade vivida e partilha com seus semelhantes, que será realizada através de dados coletados em uma entrevista. "Pesquisa de campo", realizada na Escola Santo Cristo, no município de Ipojuca, situado ao sul de Pernambuco.

\section{PROBLEMÁTICA E JUSTIFICATIVA}

Com o proposito de apresentar a temática de pessoas com deficiência intelectual no processo de desenvolvimento da aprendizagem, observou-se no contexto vivenciado nesse século XXI e constatou-se que Educação Especial é um grande avanço na sociedade brasileira, pois é o reconhecimento da cidadania e equidade, princípios dos direitos humanos, despontando com propostas educacionais inovadoras em prol das pessoas com deficiência intelectual e com novas abordagens e conceitos, tendo como consequência a reformulação cultura que conduz a integração na escola dos chamados excluídos.

Segundo Amaralian(1986), a discriminação e a marginalização acarretam problemas também na autoestima e no próprio ajustamento social do deficiente intelectual. os pressupostos metodológicos estão embasados na discussão e pesquisa de autores representantes da concepção histórico-cultural, mais especificamente Vygotsky (1896-1934), o qual defende a ideia de que a pessoa deficiente é diferente das pessoas consideradas normais, apenas é alguém que se desenvolve de outro modo.

Para tanto, é necessário que se faça uma breve exposição sobre o contexto mundial que proporcionou a atual evolução que assume uma perspectiva inclusiva na modalidade de ensino. A história da deficiência intelectual acompanha de perto a evolução da conquista e formulação dos "Direitos Humanos". A humanidade nos comprova que em todas as épocas pessoas nascem com deficiência intelectual e enfrentam dificuldades no convívio social e escolar, devido aos preconceitos. Desde a antiguidade existe a dificuldade em lidar e aceitar as diferenças entre as pessoas, a cada momento histórico os deficientes intelectuais são tratados de maneiras diversas, pois o conceito e os conhecimentos sobre essa deficiência mudam e multiplica-se em toda a história da humanidade. Nesta perspectiva, mostrar-se-á a trajetória da lida da sociedade com pessoas com deficiência intelectual, ao longo do tempo. 
A inclusão de alunos com necessidades educacionais especiais tem de um modo geral, aumentado gradativamente no sistema público brasileiro (Brasil, 2005). Promovendo a reflexão sobre as dificuldades encontradas pelas pessoas com deficiência intelectual, considerando sua maior complexidade principalmente, na organização das práticas pedagógicas para construção da cidadania, onde se elenca os fatores que dificultam ou criam obstáculos ao processo inclusivo.

Diante da pergunta norteadora: Quais os procedimentos que são desenvolvidos com os deficientes intelectuais para o melhor processo de aprendizagem? E do objetivo de analisar as principais metodologias e os procedimentos que os professores utilizam com o deficiente intelectual no processo de aprendizagem, analisa-se, a luz dos teóricos, o papel da família na educação e na inclusão social do deficiente intelectual;

\section{HISTÓRIA}

A evolução da educação especial segue segundo paradigmas sociais, que se desenvolvem a partir da concepção humana de sociedade e trabalho, vindoura de cada momento da história.

Segundo Mazzotta (1996), conforme citado em apud RECIFE (2015, p 23), "tais concepções relacionadas às pessoas com deficiência, até o século XVIII, eram basicamente ligadas ao misticismo e ocultismo, não havia base científica para o desenvolvimento de noções realísticas." Normalmente esses indivíduos eram abandonados à própria sorte e enfrentam dificuldades no convívio social devido aos preconceitos. Desde a antiguidade existe a dificuldade em lidar e aceitar as diferenças entre as pessoas. Essas pessoas mostravam-se dependentes, por esse motivo, eram abandonadas.

Esse afastamento, remota a segregação e a discriminação daqueles que figuram de alguma forma aos padrões estéticos, comportamentais ou de saúde, essa era a visão que a sociedade tinha com relação ao deficiente intelectual.

Durante a revolução industrial a descriminação passou a ser mais presente. Ao defender que não havia espaço para os considerados improdutivos. No nosso país, o reconhecimento da educação especial se deu primeiramente, com a criação do instituto de Meninos Cegos, em 1854, atualmente chamado Instituto Benjamim Constant. Posteriormente, o Instituto de Surdos-Mudos, atualmente conhecido como Instituto Nacional de Educação de Surdos (INES), em 1874. Após essas instituições, outras surgiram com o modelo assistemático, e esse tipo de assistência perpetuou-se a partir daí.

Como falado por Recife (2015, p 23), "No tocante às pessoas com deficiência intelectual, a psicóloga e educadora russa Helena Antipoff, organizou a sistematização da educação, por meio da Fundação Sociedade Pestalozzi, atuando na formação profissional deste segmento."

Em sequência, foi criada a Associação de Pais e Amigos dos Excepcionais (APAE), providenciando o atendimento e colaboração para indivíduos com necessidades especiais, de forma assistencialista, onde, a legislação vem acontecendo para apoiar a educação especial.

É importante ressaltar que a educação especial é apoiada nas legislações, que tem como princípio defender a equidade social, ou seja, a igualdade de oportunidades para todos os indivíduos, independentemente de suas características. Em 2015, foi criada a LBI, também chamada de Estatuto da Pessoa com deficiência. Que traz inovações acerca das leis elaboradas pela jurisprudência.

\section{LEIS DE INCLUSÃO DE DEFICIENTES}

O conceito de inclusão surgiu através de movimentos mundiais e tem sua própria história, nos países mais desenvolvidos, abrangendo também países em desenvolvimento.

Segundo o documento da Declaração de Salamanca, "o princípio fundamental da escola inclusiva é o de que todas as crianças deveriam aprender juntas, independentemente de quaisquer dificuldades ou diferenças que possam ter. Onde a educação inclusiva fundamentam-se nos direitos humanos reafirmados no art.1, da convenção internacional sobre os direitos das pessoas com deficiência, com o propósito de "promover, proteger e assegurar o exercício pleno e equitativo de todos os direitos humanos e liberdades fundamentais para todas as pessoas com deficiência e promover o respeito pela sua dignidade inerente"(Brasil,2007,p.17).

Uma Assembleia Geral da Organização das Nações Unidas (ONU) adotou o texto da Convenção sobre os direitos das pessoas com deficiência. Como afirma-se no Dereto 6949/09: 
a) 0 pleno desenvolvimento do potencial humano e do senso de dignidade e autoestima, além do fortalecimento do respeito pelos direitos humanos, pelas liberdades fundamentais e pela diversidade humana;

b) 0 máximo desenvolvimento possível da personalidade e dos talentos e da criatividade das pessoas com deficiência, assim como de suas habilidades físicas e intelectuais;

c) Adaptações razoáveis de acordo com as necessidades individuais sejam providenciadas;

d) As pessoas com deficiência recebam o apoio necessário, no âmbito do sistema educacional geral, com vistas a facilitar sua efetiva educação;

e) Medidas de apoio individualizadas e efetivas sejam adotadas em ambientes que maximizem o desenvolvimento acadêmico e social, de acordo com a meta de inclusão plena.

A conquista do modelo da inclusão escolar foi bastante defendida e solidificada a partir de movimentos de diferentes nacionalidades, da legislação e da elaboração dos planos gerais de educação. Onde a escola inclusiva deve reconhecer e responder às necessidades diversas de seus estudantes, acomodando ambos os estilos e ritmos de aprendizagem e assegurando uma educação de qualidade a todos através de um currículo apropriado, arranjos organizacionais, estratégias de ensino, usam de recursos e parcerias com as comunidades.

Inclusão e participação são essenciais à dignidade humana e ao gozo e exercício dos direitos humanos no campo da educação, também considera a deficiência como uma necessidade especial, e valorizar as diferenças e a heterogeneidade como forma de crescimento para todos. (SANTOS, 1993, p.16).

A educação inclusiva tem sido conceituada como um processo de educar conjuntamente e de maneira incondicional, nas classes de ensino regular, estudantes ditos "normais" com estudantes deficientes, se apoiando na afirmação de que a inclusão beneficia a todos; uma vez que, sentimentos de respeito à diferença de cooperação e a solidariedade podem se desenvolver plenamente numa sala de aula. Segundo Fonseca (1989), "se não há nenhuma razão para segregar os seres humanos, à base da idade, sexo, cor da pele e religião, também não deve haver a base da capacidade da aprendizagem".

Guiando-se nos documentos internacionais, o Ministério da Educação (MEC) estabelece a Política nacional de educação especial na perspectiva da educação inclusiva em 2008. Nela estão determinadas as diretrizes de ação para a concepção de políticas públicas locais e práticas pedagógicas voltadas à inclusão escolar. Uma das principais contribuições dessa medida foi reformular o papel da educação especial por meio do estabelecimento do atendimento educacional especializado (AEE). Ela também foi a grande norteadora da meta 4 do Plano nacional de educação (PNE) estabelecido em 2013. Em 2014, foi promulgado o Plano nacional de educação (PNE), que prevê a universalização do acesso à educação básica e ao AEE para o público-alvo da educação especial até 2024. Em 2015, finalmente, foi aprovada a Lei brasileira de inclusão (LBI), que traz uma série de inovações, como a proibição da negação de matrícula e de cobrança de taxas adicionais em casos de estudantes com deficiência.

Reconhecendo que a deficiência é um conceito em evolução e que a incapacidade resulta na interação entre pessoas com déficit e as barreiras devidas às atitudes e ao ambiente que impedem a plena e efetiva participação dessas pessoas na sociedade em igualdade de oportunidades com as demais pessoas;

De acordo com Vygotsky (2010, p. 65) "Basta mudar o meio social para que se mude incontinenti o comportamento do homem". Assim sendo, a cultura é responsável pelo processo evolutivo da humanidade, que parte da concepção do homem para uma percepção bem mais complexa que envolve os aspectos sociais, influenciado por ações que determinam a convivência entre os indivíduos e suas regras.

Apresentando todas essas conquistas legais, historicamente construídas, se percebe como esse público cresceu, amadureceu e conquistou espaço, nunca visto. É importante destacar que cabe a educação conscientizar os deficientes desses direitos, para que exerçam efetivamente sua cidadania, por meio de seus responsáveis.

\section{CONSIDERAÇõES FINAIS}

A efetivação de uma prática educacional inclusiva não será garantida por meio de leis, decretos ou portarias que obriguem as escolas a aceitarem os estudantes com deficiências, ou seja, a presença física desses estudantes deficientes nas classes regulares não é garantia de inclusão. 
A escola precisa estar preparada para trabalhar com os estudantes independentemente de suas diferenças ou características individuais.

Somente a partir da transformação dos sistemas educacionais, da redefinição dos conceitos, atitudes e práticas poderão ser construídas redes de relações de promoção da participação, e do incentivo a construção coletiva da identidade escolar e da valorização da diversidade no contexto educacional.

\section{REFERÊNCIAS}

[1] Almeida, A. L. J. A pessoa com deficiência em Portugal e Brasil: desafios para ações em saúde. Hygéia, v. 2, n. 3, p. 47-56, 2011.

[2] _ _ _ Fundamentos de educação especial. 2 Ed.São Paulo: Pioneira, 2005.

[3] Montoan, Maria Teresa. Compreendendo a deficiência Mental, novos caminhos Educacionais. Rio de Janeiro. Ed. Scipione,1992.

[4] Paganelli, Raquel. Eleição. 2018: Como fica a educação das crianças com deficiência?2018.

[5] Recife, Secretaria de Educação, Educação Inclusiva: múltiplos olhares / in: Barros, J M L B; Souza, K M. Politica de ensino da rede municipal do Recife. v.5, p. 23, 2015.

[6] Sassaki, Romeu Kazumi. O direito à educação inclusiva, segundo a ONU, 2013.

[7] Santos, Martinha Clarete Dutra. Marcos legais da educação infantil inclusiva,2016.

[8] Equipe Diversa, Convenção sobre os direitos das pessoas com deficiência e inclusão escolar no Brasil,2018.https://www.educabrasil.com.br/declaracao-de-salamanca/ 


\section{Capítulo 17}

Inclusão socioeducacional da pessoa com deficiência através da atividade física, do turismo social e de eventos socioculturais - um relato de experiência

\section{Izabeli Sales Matos}

\section{Artur José Braga de Mendonça}

Resumo: 0 presente trabalho relata a experiência do Projeto Sesc Ativo - Núcleo Pessoa com Deficiência, que emergiu a partir de uma pesquisa qualitativa, do tipo estudo de caso. O estudo teve como objetivo investigar as contribuições das atividades psicomotoras aquáticas para o desenvolvimento da pessoa com surdocegueira. Por intermédio desta pesquisa, evidenciou-se a relevância da prática da atividade física para a mobilidade, comunicação e o desenvolvimento do surdocego, contribuindo significativamente para o seu processo de inclusão sócio educacional. Tendo como premissa o resultado dessa investigação, foi implantado o Projeto Sesc Ativo - Núcleo Pessoa com Deficiência, uma parceria entre as instituições Associação de Cegos do Ceará e Serviço Social do Comércio - Fortaleza. 0 citado projeto, em seu primeiro ano, contava com 36 alunos - incluindo pessoas com deficiência visual, surdocegueira e múltipla deficiência (com déficit visual) - e desenvolvia atividade aquática e musculação. Atualmente atende a 300 alunos, disponibilizando as modalidades de musculação, ciclismo indoor, ginástica funcional, natação, hidroginástica e psicomotricidade aquática, além do turismo social e da participação em eventos socioculturais e esportivos. Também contribui para a difusão de saberes e pesquisas na área da educação especial e inclusão da pessoa com deficiência e atividade física adaptada.

Palavras-chave: Pessoa com deficiência; Inclusão; Atividade física. 


\section{INTRODUÇ̃̃O}

Com o presente relato, tratamos de socializar a experiência de um projeto que se tornou referência para outras instituições que buscam efetivar a inclusão social como prática do cotidiano, no Brasil. O Projeto Sesc Ativo - Núcleo Pessoa com Deficiência foi implementado a partir de uma pesquisa realizada através do curso de especialização em Psicomotricidade da Universidade Estadual do Ceará (UECE). A citada pesquisa, de cunho qualitativo, do tipo estudo de caso, investigou as contribuições das atividades psicomotoras aquáticas para o desenvolvimento da pessoa com surdocegueira, deficiência que apresenta comprometimentos psicomotores, de comunicação e de socialização advindos das perdas sensoriais (audiovisuais), o que, como consequência, afeta o processo de inclusão socioeducacional dessa pessoa.

Apoiamo-nos em reflexões teóricas de estudiosos como: Bueno e Martín (2003), Costallat (2002) e Fonseca (1995), que tratam dos aspectos conceituais e estruturais da psicomotricidade; Gutierres Filho (2003), que nos alerta sobre a atividade aquática realizada de forma lúdica; além de Amaral (2002), Arias (2004) e Cormedi (2005), que abordam temas relacionados ao desenvolvimento e ao atendimento educacional da criança surdocega. Baseados nesses autores, estudamos acerca da psicomotricidade, da atividade física e das relações interpessoais em meio aquático, ademais de contemplar aspectos inerentes ao indivíduo surdocego e suas implicações diante das perdas auditivas e visuais.

Por intermédio desta investigação, verificamos que "[...] é possível facilitar o processo de comunicação, promovendo a melhoria das relações socioafetivas e o desenvolvimento geral da pessoa com surdocegueira" (MATOS, 2006, p. 76). Identificamos que as práticas psicomotoras contribuem significativamente para o desenvolvimento da pessoa surdocega, favorecendo o seu processo de inclusão, por influenciar positivamente na comunicação do indivíduo surdocego, público-alvo da investigação.

Tendo em vista os resultados desta pesquisa, acreditamos na importância de dar prosseguimento a esse trabalho de estimulação aquática, de tal forma que a sociedade, na prática, fosse beneficiada com o resultado da pesquisa. Em razão disso, surgiu a ideia de juntar as partes: por um lado, o Serviço Social do Comércio (Sesc) - Fortaleza, por ter uma infraestrutura adequada e um olhar diferenciado para a prática da inclusão social, e, por outro lado, a Associação de Cegos do Estado do Ceará (ACEC), com seus usuários que ali buscam melhorar a qualidade de vida e serem partícipes de uma sociedade, como todo cidadão.

Por conseguinte, da união de esforços entre os pesquisadores e as instituições SESC e ACEC surgiu o Projeto Sesc Ativo - Núcleo Pessoa com Deficiência, que deu amplitude para que suas ações não somente atendessem a pessoas com surdocegueira, mas também a indivíduos com outras deficiências, especialmente pessoas com deficiência visual.

Assim, ao final do primeiro ano, 2007, contemplamos a Escola de Ensino Fundamental Instituto dos Cegos do Ceará e ampliamos o quantitativo de alunos assistidos, incluindo pessoas com deficiência visual, surdocegueira e múltipla deficiência, além dos familiares destes, totalizando 36 alunos. Nesse período, o SESC nos disponibilizou uma equipe de colaboradores composta por três profissionais de Educação Física e um estagiário da mesma área, o que favoreceu a realização de um trabalho de qualidade. Quanto às modalidades desenvolvidas, contávamos com atividades na piscina (psicomotricidade, natação e hidroginástica) e musculação. Essas atividades eram de livre escolha dos discentes, respeitando suas particularidades e individualidades, e os programas eram elaborados de forma personalizada e aplicados em pequenos grupos.

Com o passar dos anos, o Projeto Sesc Ativo - Núcleo Pessoa com Deficiência foi se tornando referência no tocante à trilogia atividade física, pessoa com deficiência e inclusão socioeducacional; diante da crescente demanda, fomos impelidos a ampliar nossos limites, diversificando nossas modalidades de atendimento e ainda mais nosso público-alvo. Em 2010, diante das mudanças advindas do constante movimento rumo à inclusão educacional da pessoa com deficiência no Brasil, como reflexo também do movimento mundial para esse fim, o Ceará instituiu o Centro de Referência em Educação e Atendimento Educacional Especializado do Ceará (CREAECE), equipamento que abrange o atendimento a pessoas com deficiência, além de alunos com altas habilidades e superdotação. Nesse período, o Núcleo Pessoa com Deficiência ampliou seus serviços e passou a atender educandos também do CREAECE, bem como de outras instituições de atendimento especializado a pessoas com deficiência. 
Assim, conforme referimos, com base nos estudos de Matos (2006), que afirmam as contribuições da prática da atividade física realizada de forma lúdica para o desenvolvimento social e psicomotor de pessoas com surdocegueira, o Projeto Sesc Ativo - Núcleo Pessoa com Deficiência vem se firmando ao longo dos anos, delineando sua proposta, ampliando e diversificando sua clientela e atividades desenvolvidas. Atualmente disponibilizamos das modalidades de musculação, ciclismo indoor, ginástica funcional, natação, hidroginástica e psicomotricidade aquática, além do turismo social e da participação em eventos socioculturais e esportivos. As práticas são desenvolvidas de forma lúdica e criativa em detrimento dos exercícios repetitivos.

Como nos ensina Gutierres Filho (2003, p. 15), “[...] não se trata de ensinar exercícios ou práticas natatórias, como ensino tradicional, mas apenas deixar a criança apropriar-se da água, conhecer a sua natureza e perceber seu contato para desfrutar de todas as brincadeiras". Buscamos, por intermédio da atividade física, em meio aquático ou não, ampliar o espaço de vivências corporais, priorizando as relações interpessoais e com o meio, visando à melhoria da comunicação e interação social entre os envolvidos no projeto. Disponibilizamos a pessoas com surdocegueira, deficiência visual, auditiva, física e intelectual, com múltipla deficiência, bem como a sujeitos com altas habilidades e superdotação, a prática sistemática da atividade física de forma lúdica, favorecendo as relações interpessoais e afetivas e o desenvolvimento psicomotor. Vale ressaltar que temos como meta incentivar a prática consciente e permanente da atividade física de modo prazeroso, através da ação educativa, prepositiva e transformadora, fortalecendo a capacidade de os indivíduos buscarem, eles mesmos, a melhoria de sua qualidade de vida, o que contribui diretamente para o processo de inclusão educacional e social do aluno assistido pelo projeto.

Quanto ao turismo social, trata-se de aulas de campo nas quais promovemos o lazer e o turismo acessível a pessoas com deficiência, altas habilidades e superdotação, público-alvo atual do projeto, em diversos espaços da cidade de Fortaleza e municípios vizinhos, considerando seu expressivo acervo de bens naturais, culturais e sociais. 0 turismo social possibilita o conhecimento de pontos turísticos e históricos (praias, parques, resorts, exposições, cidades históricas e outros), gerando o sentimento de pertencimento ao ambiente visitado, utilizando o conhecer e o experimentar como forma de ampliar experiências e contribuir para a inclusão social.

Nessa mesma proposta, evidenciamos os eventos socioculturais e esportivos disponibilizados, que em geral ocorrem anualmente, sendo parte do calendário de eventos do SESC, como a Caminhada Louis Braille, que, além de celebrar o Dia Nacional do Braille, conclama a sociedade ao cumprimento e ao respeito dos direitos do cidadão, e mais especificamente, da pessoa com deficiência visual.

Por ocasião dessa Caminhada, são evidenciadas a relevância das atitudes cidadãs a pessoas com deficiência, nas ruas e estabelecimentos, como oferecer cardápio em Braille em restaurantes, ajudar na mobilidade de pessoas, informar obstáculos na via, oferecer apoio para atravessar a rua e subir em transportes coletivos. São lembrados também os recursos de acessibilidade previstos na Lei Brasileira de Inclusão da Pessoa com Deficiência, como implantação de passarelas, pisos táteis ou linhas-guia em trechos estratégicos na área urbana.

Desta forma, esse evento configura-se como importante espaço de reivindicações políticas de cidadania das pessoas com deficiência visual, em Fortaleza, no qual conclamamos a sociedade para disponibilizar mecanismos favoráveis à acessibilidade diante das pessoas com deficiência visual, além de outras deficiências.

Destacamos também o Circuito de Corridas e o Dia do Desafio, que têm como objetivo motivar a população à prática da atividade física de forma sistemática e propositiva, bem como o Festival de Quadrilha e o Palco Giratório, este último constitui um relevante projeto de difusão das artes cênicas que visa em especial à formação de plateias a partir da circulação de espetáculos em vários estados brasileiros (capitais e interiores).

\section{CONSIDERAÇÕES FINAIS}

Com efeito, convém mencionar que atualmente contamos com o público-alvo de 300 alunos (pessoas com deficiência, altas habilidades e superdotação), sendo priorizadas pessoas comerciárias, seus dependentes, alunos ou egressos da rede pública de ensino. Para atender a esse contingente, disponibilizamos de 17 professores de Educação Física, dois supervisores do Sesc Fortaleza e uma coordenadora pedagógica cedida pela ACEC. 
Acresce referir que o projeto tem sido, com frequência, espaço de novos estudos através da formação continuada que é ofertada aos professores. Essas são extremamente importantes, considerando sua necessidade em virtude da diversidade dos estudantes, além das constantes reflexões acerca dos saberes e práticas pedagógicas relacionadas à inclusão socioeducacional da pessoa com deficiência. Outrossim, pela razão citada, somos constantemente solicitados por universidades e alunos como campo de investigação, possibilitando estudos e aprofundamentos na área da educação especial, inclusão e atividade física. 0 Projeto Sesc Ativo - Núcleo Pessoa com Deficiência também tem sido procurado por unidades do SESC de municípios do Ceará e de outros estados do Brasil, servindo como referência para novas experiências de trabalho de inclusão da pessoa com deficiência nessas unidades.

Vale ressaltar que, dentre outros eventos científicos e acadêmicos, esse estudo foi apresentado por ocasião do I Congresso Internacional da Deficiência Visual e II Congresso da Associação de Cegos e Amblíopes de Portugal (ACAPO), intitulado "Sociedade Inclusiva + Participação Responsável = Cidadania Plena". Esses foram realizados na Fundação Calouste Gulbenkian, em Lisboa, Portugal, no período de 11 a 13 de abril de 2019, tendo sido patrocinado pela Sua Excelência o Presidente da República.

Ante o exposto, esta experiência nos permite ratificar a relevância da prática da atividade física como estratégia pedagógica facilitadora do processo de inclusão socioeducacional da pessoa com deficiência. Dessa forma, pretendemos continuar contribuindo com esse processo, sendo também uma fonte de pesquisa e suporte para a prática perante o grande desafio da inclusão social e educacional da pessoa com deficiência.

\section{REFERÊNCIAS}

[1] Amaral, Isabel. A educação de estudantes portadores de surdocegueira. In: Masini, Elcie Aparecida Fortes Salzano (Org.). Dos sentidos... pelos sentidos... para os sentidos: sentidos das pessoas com deficiência sensorial. São Paulo: Vetor, 2002. p. 121-144.

[2] Arias, Márcia Helena Ramos. Perfil clínico social do indivíduo surdocego. 2004. 87 f. Dissertação (Mestrado em Saúde Coletiva) - Programa de Pós-Graduação em Saúde Coletiva, Universidade Estadual de Campinas, Campinas, 2004.

[3] Bueno, Salvador Toro; Martín, Manuel Bueno. Deficiência visual: aspectos psicoevolutivos e educativos. São Paulo: Santos, 2003.

[4] Cormedi, Maria Aparecida. Referências de currículo na elaboração de programas educacionais individualizados para surdocegos congênitos e múltiplos deficientes. 2005. 216 f. Dissertação (Mestrado em Psicologia do Desenvolvimento) - Programa de Pós-Graduação em Distúrbios do Comportamento, Universidade Mackenzie, São Paulo, 2005.

[5] Costallat, Dalila de. A psicomotricidade otimizando relações humanas. São Paulo: Arte e Ciências, 2002.

[6] Fonseca, Vítor da. Manual de observação psicomotora: significação psiconeurológica dos fatores psicomotores. Porto Alegre: Artmed, 1995.

[7] Gutierres Filho, Paulo. A psicomotricidade relacional em meio aquático. Barueri: Manole, 2003.

[8] Masini, Elcie Aparecida Fortes Salzano (Org.). Dos sentidos... pelos sentidos... para os sentidos: sentidos das pessoas com deficiência sensorial. São Paulo: Vetor, 2002.

[9] Matos, Izabeli Sales. Atividades psicomotoras aquáticas no desenvolvimento da pessoa com surdocegueira. Fortaleza: Premius, 2006. 


\section{Capítulo 18}

O atendimento educacional especializado para cursos de nível médio técnico em uma instituição da rede federal de educação: Possibilidades rumo à institucionalização

Cláudia Terra do Nascimento Paz

Cláudia Medianeira Alves Ziegler

Resumo: Este trabalho objetiva visibilizar as ações desenvolvidas rumo à institucionalização do Atendimento Educacional Especializado em uma Instituição da Rede Federal de Educação, que atua com cursos técnicos de nivel médio. A Instituição prevê reserva de vagas para o ingresso de alunos com necessidades educacionais específicas. Apesar do direito de ingresso, ainda está-se lutando pelas garantias legais à permanência desses alunos. Inicialmente, os Núcleos de Atendimento às Pessoas com Necessidades Educacionais Específicas surgiram como garantia à educação inclusiva. No entanto, o que se observa é que, por vários motivos, tais expectativas acabam frustradas. A exemplo disso, temos o Atendimento Educacional Especializado, que ainda não foi institucionalizado. Como possibilidade, em um de seus Campi, está-se desenvolvendo ações que poderão servir de base para esse intento. Rumo à institucionalização, a fundamentação teórica fica por conta da legislação vigente (Lei 9.394/1996; Lei 13.409/2016; Decreto 7.611/2011) e de autores, tais como Mantoan (2007); Moysés (2014); Marchesi e Pérez (2004). Tais ações iniciaram através de um projeto de ensino e, em 2019, através de um curso de extensão, com matrícula no contra turno e cômputo da carga horária docente. Os atendimentos individuais, foram realizados por professora efetiva, com formação específica, através da metodologia do estudo de caso. Como resultados conseguiu-se garantir um espaço de acolhimento e atendimento aos alunos, bem como a visibilização da importância do Atendimento Educacional Especializado na Instituição, iniciando um movimento em prol da institucionalização do mesmo.

Palavras-chave: Atendimento Educacional Especializado; Educação inclusiva; Educação profissional, técnica e tecnológica. 


\section{INICIANDO A REFLEXÃO}

Muito se discute atualmente acerca das necessidades educacionais específicas. Tenta-se, através de várias vertentes teóricas, algumas tradicionais outras críticas, chegar a um entendimento acerca dos conceitos envolvidos nessa trama, suas principais características e etiologias. Assim, para as correntes tradicionais, o aluno é o responsável único pelo seu insucesso na escola, independentemente de quaisquer fatores. Já para as correntes críticas, a escola e o ensino devem estar acrescidos na equação que tenta desvendar esse fenômeno (MARCHESI e PÉREZ, 2004).

Uma das pesquisadoras mais conhecidas no meio acadêmico brasileiro a questionar a perspectiva tradicional de entendimento foi Maria Helena de Souza Patto, que no final da década de 1980 lançou a obra "A Produção do Fracasso Escolar", demonstrando o quanto trajetórias estudantis consideradas fracassadas, porque demarcadas por necessidades educacionais específicas, explicadas até então como fenômenos individuais, poderiam ser produzidas institucionalmente. Para tanto, Patto (1999) fez uma revisão crítica da literatura sobre as causas das desigualdades educacionais na sociedade brasileira e analisou as raízes históricas das concepções sobre o fracasso escolar, partindo do pressuposto de que um modelo positivista de produção de conhecimento não consegue explicar a complexidade da escola (PATTO, 1999).

Em nosso entendimento, estudantes com necessidades educacionais específicas são aqueles que passam a ser considerados especiais porque exigem respostas educacionais específicas e adequadas às suas necessidades individuais (CRUZ, 2009). Nesse sentido, concordamos com Mantoan (2007) de que é a escola que deve adaptar-se às diferenças e não o contrário, proporcionando a todos os alunos condições favoráveis ao processo de aprendizagem, em iguais condições. Esta compreensão parece ser de difícil entendimento e execução dentro das instituições de ensino e foi justamente o que Patto (1999) encontrou em suas pesquisas.

Uma das explicações possíveis para essa realidade, talvez seja o fato de que, de acordo com Moysés (2014), as necessidades educacionais específicas foram transformadas em doença na escola, seja pelos interesses de funcionamento da ciência, seja pela incompetência que temos em trabalhar com a diferença, nesse caso, com a diferença no processo de aprendizagem. Muitas vezes, esses são sujeitos marcados pela reprovação e pelo preconceito em circulação na sociedade e na própria escola.

Como afirma a autora, esses são sujeitos que "conquistaram o direito de entrar pelos portões da escola, mas ainda não conseguiram, apesar de toda sua resistência, de sua teimosia em querer aprender, derrotar o caráter excludente da escola brasileira" (MOYSÉS, 2014, p. 09). Nesse sentido, parece haver uma invisibilidade desses alunos, que não são considerados nos planejamentos de ensino e avaliativos.

O Estatuto da Pessoa com Deficiência (Lei n ${ }^{\circ} 13.409$ de 2016), que assegura o direito à educação dentro de um sistema inclusivo, pode ser citado, conjuntamente com a Constituição Federal (1988) e da Lei de Diretrizes e Bases da Educação Nacional (1996), como importantes legislações sobre o tema. A perspectiva da educação inclusiva prevê ainda que as possibilidades de permanência desses alunos sejam consideradas, tal qual resume a Nota Técnica $n^{\circ} 106$ do MEC/SECADI/DPEE (MEC, 2013), que orienta a implementação da Política Institucional de Acessibilidade na Rede Federal de Educação Profissional, Científica e Tecnológica. O Decreto $\mathrm{n}^{\circ} 7.611$ (BRASIL, 2011) trata especificamente do AEE, reafirmando sua importância enquanto garantia legal a uma educação verdadeiramente inclusiva.

Tais legislações consideram que a inclusão não implica apenas no ingresso do aluno, este já garantido pela Instituição de Ensino através de reserva de vagas, mas em ações que se revertam na permanência desses estudantes na Instituição, até a diplomação. No caso específico do estudo em questão, estamos tratando de uma Instituição da Rede Federal de Educação Profissional e Tecnológica, que atua com estudantes de nível médio técnico, que ainda não possui o AEE institucionalizado. Ou seja, os estudantes de nível médio, pertencentes a cursos técnicos integrados ao ensino médio, mesmo quando entram por reserva de vagas para alunos com necessidades educacionais específicas, ficam sem o atendimento especializado, no contra turno das atividades escolares regulares.

A inexistência do AEE impacta, portanto, na ausência de atendimento pedagógico específico aos estudantes e auxílio especializado aos docentes da sala de aula regular em seus processos de reflexão e organização das adaptações curriculares para esses alunos. 0 referido Instituto Federal em questão regrou recentemente, através de resolução própria a realização de Planos Educacionais Individualizados (PEI) para estudantes de inclusão que demandam de adaptações curriculares.

Nesse momento, torna-se importante salientar que o Plano Educacional Individualizado apareceu no cenário nacional como uma possibilidade de instituir as adaptações curriculares para cada estudante, a 
partir de suas demandas individuais, possibilitando uma avaliação processual das aprendizagens. No entanto, a inexistência do AEE pode impactar, inclusive, na organização desses PEIs e das adaptações curriculares como um todo, pois, nesses casos, os professores da sala de aula regular ficam sem orientação especializada de como proceder com o aluno em sala de aula.

Já sabemos que parece existir uma linha colaborativa muito importante entre os professores da sala de aula regular e o professor especialista de AEE na construção de processos educativos inclusivos (PAZ, 2018). Desta forma, a inexistência desse serviço ou de qualquer alternativa pedagógica ao mesmo implica na ausência de uma política institucional que trabalhe em prol da permanência desses estudantes, tendo como consequência imediata dificuldades institucionais na concretização até mesmo de adaptações curriculares abrangentes para esse público.

Outro ponto a ser considerado, relaciona-se à quase total inexistência de publicações científicas sobre a realização de AEE para alunos de cursos técnicos de nível médio. Quase toda a experiência relatada cientificamente sobre AEE refere-se ao ensino fundamental. No entanto, alunos de nível médio também são sujeitos da educação básica, e, nesse sentido, têm o mesmo direito à educação inclusiva e ao AEE. Menos relatada ainda, são experiências exitosas de alunos de inclusão em cursos técnicos de nível médio.

Para se ter uma ideia da questão aqui relatada, o número de alunos com alguma deficiência cursando o ensino médio triplicou na última década. Atualmente, eles representam 0,8\% do total de matrículas neste nível de ensino, de acordo com o Censo Escolar do MEC de 2015. Assim, temos, atualmente, cerca de 62 mil estudantes com alguma deficiência matriculados no ensino médio, frequentando as salas de aula regular, números absolutos que computam os alunos da rede federal de educação profissional e tecnológica (INEP, 2015).

Como alternativa a esta realidade, está-se desenvolvendo em um Campus da rede de Institutos Federais, da região sul do país, uma experiência alternativa, que trata do desenvolvimento de ações pedagógicas especializadas, voltadas para alunos de cursos técnicos integrados de nível médio ${ }^{13}$ do referido Instituto, que possuam necessidades educacionais específicas. A partir de avaliação pedagógica inicial, as atividades são planejadas e executadas individualmente com os alunos, a partir do modelo de estudos de caso, buscando orientar a equipe de professores quanto as adaptações curriculares, elaboração de materiais didáticos e avaliativos, bem como ofertando um espaço onde os alunos possam ser acolhidos e ouvidos. Nesse contexto, este trabalho tem como objetivo visibilizar tais ações, que são desenvolvidas visando a institucionalização do Atendimento Educacional Especializado (AEE) junto à Instituição e Ensino

\section{UMA EXPERIÊNCIA ALTERNATIVA}

A rede federal de educação encontra-se composta pelas universidades federais, que atuam prioritariamente com o ensino de nível superior, graduações e pós-graduação, e pelos institutos federais, que atuam com educação superior, básica e profissional, pluricurricular e multicampi, especializados na oferta de educação profissional e tecnológica nas diferentes modalidades de ensino.

Se a rede de universidades federais é bastante conhecida no país, já que é centenária, o mesmo não se pode dizer dos institutos federais, que possuem pouco mais de uma década de existência formal, nesse modelo. Esses últimos foram criados através da Lei no 11.892, de 29 de dezembro de 2008, a qual estabeleceu, no âmbito do sistema federal de ensino, a Rede Federal de Educação Profissional, Científica e Tecnológica, vinculada ao Ministério da Educação (BRASIL, 2008).

A presença de vários campi em vários municípios, atendendo a diferentes realidades produtivas locais e comunidades com necessidades específicas, torna cada Instituto em uma instituição com o desafio de ser um dos protagonistas do desenvolvimento socioeconômico da comunidade na qual está inserida, a partir da educação pública, gratuita e de excelência.

A diversidade de valores e necessidades na área educacional a que se propõe, busca valorizar a educação em todos os seus níveis, contribuindo com o desenvolvimento do ensino, da pesquisa e da extensão, oportunizando de forma expressiva a educação pública de excelência e fomentando o atendimento das demandas locais, com atenção especial às camadas sociais que carecem de oportunidades de formação e de incentivo à inserção no mundo do trabalho.

\footnotetext{
${ }^{13}$ Cursos técnicos integrados de nível médio, também chamados de ensino médio técnico, oferecem a formação geral de forma integrada à formação profissional. A duração é de três ou quatro anos, dependendo de cada curso e o aluno precisa ter o ensino fundamental completo para cursá-lo.
} 
Nesse contexto, de municípios e realidades locais tão distintas, desde sua criação várias redes de Institutos Federais optaram por destinar 5\% de suas vagas para o ingresso de alunos com necessidades educacionais específicas através da reserva de vagas, tal qual propõe a Lei no 12.711 (BRASIL, 2012). Atualmente, o Instituto Federal em questão conta com mais de 400 estudantes nessa condição.

Tem-se a ciência de que diante do princípio constitucional do direito de educação para todos, legitimado a partir de extensa legislação que efetiva a educação inclusiva no Brasil, discussões sobre as premissas dessa educação têm sido ampliadas, apontando que é a instituição que deve adaptar-se às demandas e necessidades de aprendizagem dos alunos e não o contrário.

No entanto, apesar de o ingresso estar garantido, quando pensamos na permanência, a realidade é diferente, pois ainda não se conseguiu institucionalizar o Atendimento Educacional Especializado (AEE), mesmo sendo esse um dos principais dispositivos legais de garantia à educação inclusiva no país, juntamente com as adaptações curriculares.

Assim sendo, este estudo busca apresentar uma experiência alternativa, que está sendo implementada em um Campus de um Instituto Federal do Região Sul do país, em busca da institucionalização do AEE na referida instituição de ensino, cientes de que a educação inclusiva é um dos princípios que rege a criação da própria rede de Institutos Federais, conforme preconiza a sua lei de criação, Lei no 11.892/2008.

Buscando trazer essa temática para o mundo visível, o Campus em questão, com apoio da própria Reitoria do Instituto, organizou um projeto de ensino, que busca subsidiar o exercício da docência numa perspectiva inclusiva, objetivando conhecer e auxiliar os alunos em suas dificuldades e potencialidades, oportunizando aos mesmos um momento de desenvolvimento de suas habilidades cognitivas e metacognitivas, bem como ofertando um espaço onde os alunos possam ser acolhidos e ouvidos em suas necessidades de aprendizagem.

O primeiro desafio consitutiu-se em organizar o próprio espaço, onde as atividades seriam desenvolvidas. Nesse sentido, a sala contou com uma organização diferente daquela prevista nos documentos do MEC, pois a demanda do público adolescente, pertencente aos cursos técnicos integrados de nivel médio, assim carecia. Buscou-se uma organização que privilegiasse a utilização de recursos digitais, através de aplicativos e de objetos de aprendizagem. Outro desafio foi localizar instrumentos pedagógicos especializados que fossem adequados para o público em questão.

O referido projeto, então, além de trazer uma opção de trabalho e aporte pedagógico especial para alunos com necessidades educacionais específicas, possibilitou o aprofundamento de estudos acerca das temáticas da educação inclusiva, constituindo-se em um momento importante para a consolidação de ações desse tipo no referido Instituto Federal. Também auxiliou a equipe de professores nas suas ações didático-pedagógicas, na medida em que subsidiou possíveis adaptações curriculares, bem como elaboração de materiais didáticos e avaliativos.

No ano de 2019, o projeto de ensino foi transformado em curso de extensão, buscando-se dar mais um passo em direção à institucionalização do AEE na Instituição. Com esta nova configuração, os alunos foram matriculados no curso, junto ao SISTEC, bem como junto ao sistema acadêmico do campus. Graças a esses registros, os alunos tiveram a dupla matrícula e a carga horária docente foi computada como hora-aula, um grande passo rumo à institucionalização das atividades.

\section{METODOLOGIA: O ESTUDO DE CASO}

0 trabalho apresentado caracteriza-se pelo desenvolvimento de atendimento pedagógico especializado, dirigido caso a caso, a partir das demandas e necessidades vivenciadas pelos sujeitos que participam do mesmo, com necessidades educacionais específicas. Assim, os sujeitos desta ação são os estudantes do próprio IFRS, especificamente do Campus Farroupilha, que apresentarem necessidades educacionais específicas. 
Nesse sentido, as ações são planejadas e desenvolvidas a partir da metodologia do estudo de caso. 0 estudo de caso é um método qualitativo que consiste em uma forma de aprofundar a análise de uma unidade individual. Conforme Yin (2001) o estudo de caso é uma estratégia de pesquisa que compreende analisar em profundidade uma situação específica, em seu contexto. De acordo com Ponte (2006, p. 2):

É uma investigação que se assume como particularística, isto é, que se debruça deliberadamente sobre uma situação específica que se supõe ser única ou especial, pelo menos em certos aspectos, procurando descobrir o que há nela de mais essencial e característico e, desse modo, contribuir para a compreensão global de um certo fenômeno de interesse.

Essa abordagem metodológica é adequada quando procuramos compreender e descrever contextos complexos, nos quais estão envolvidos diversos fatores. Yin (2001) afirma que essa abordagem se adapta à investigação em educação, quando o investigador é confrontado com situações complexas de ensinoaprendizagem. Neste caso específico, serve como horizonte metodológico, para a compreensão de demandas, planejamento e execução de ações pedagógicas especializadas voltadas para cada estudante, em suas especificidades de aprendizagem.

Cabe ressaltar que o planejamento e a execução dos atendimentos são elaborados e estudados caso a caso, conforme a demanda de aprendizagem específica de cada estudante. Esses estudantes são indicados para participação a partir de seu ingresso na Instituição, quando este se der pela reserva de vagas ou seguindo fluxo institucional definido no ano de 2017, junto à Direção de Ensino do Campus.

Cada aluno participante tem ciência e assinatura da família do Termo de Consentimento Livre e Esclarecido. Os atendimentos ocorrem uma vez por semana para cada estudante, individualmente, no contra turno de suas atividades escolares regulares, com professora efetiva do Campus, que possui formação específica para esta atuação.

Inicialmente se procede à realização de avalação pedagógica especializada, buscando-se alcançar o máximo de conhecimentos possível acerca de como cada aluno aprende, suas potencialidades e também dificuldades nesse processo. No momento seguinte, orientam-se os professores da sala de aula regular, quanto ás necessidades de adapações curriculares e procedem-se aos atendimentos semanais individualizados, buscando-se colaborar com o processo de aprendizgem dos estudantes.

Até o momento já foram atendidos, desde o ano de 2017, cerca de dezoito (18) estudantes de cursos técnicos integrados de nível médio, com os mais variados quadros. Dentre eles destacam-se o autismo, a adeficiência intelectual, a deficiência física, a discalculia, o TDA/H, dentre outros.

\section{OS AVANÇOS OBTIDOS: PRINCIPAIS RESULTADOS}

Os principais avanços obtidos até o momento, graças a visibilização da necessidade de institucionalização do AEE, relacionam-se a ações institucionais que estão sendo gestadas em parceria com a Reitoria do Instituto Federal. As principais são:

- Estudo para utilização de códigos de vagas docentes para professor de AEE, associado ao estudo para cômputo de carga horária docente para esse profissional;

- Encaminhamento para aprovação de uma Resolução Institucional, que trata da criação da política de AEE na Instituição.

Especialmente este último ponto merece detalhamento em relação às ações que deverão ser desenvolvidas, quando da aprovação da Resolução, a qual já está tramitando, em cada um dos Campi do Instituto:

- Elaboração de critérios para distribuição de vagas docentes de AEE, bem como elaboração dos requisitos mínimos para o edital de contratação desses docentes.

- $\quad$ Registro de carga horária docente em AEE, considerando que o AEE deve ser desenvolvido por docente especialista. A identificação do profissional que atua no AEE como sendo um professor é feita na Política Nacional de Educação Especial na perspectiva da Educação Inclusiva (MEC, 2008), que traz em seu texto a figura do professor para designar esse profissional, relacionando, inclusive, sua formação específica para tal atuação. Também a Resolução CNE/CEB no 04 de 2009 (MEC, 2009), no Art. 12, remetese à figura do professor, para se referir ao profissional que atua no AEE. 
- Acrescentar nos Projetos Pedagógicos dos Cursos de Nível Médio o AEE, garantindo sua institucionalização. Essa demanda está expressa na LDB (BRASIL, 1996), no Art. 12, o qual define que, entre as atribuições de uma instituição de ensino está "elaborar e executar sua proposta pedagógica". Além da LDB, essa demanda também está expressa na Resolução CNE/CEB no 04 de 2009 (MEC, 2009), em seu Art. 10, que afirma que o Projeto Político Pedagógico deve institucionalizar a oferta do AEE. Também o Decreto no 7611 de 2011 (BRASIL, 2011), Art. 2ํ, que regra o AEE, faz essa previsão, afirmando que "o AEE deve integrar a proposta pedagógica da escola".

- Estudar e implementar uma proposta que dê conta da realidade da educação superior, que é desenvolvida junto à Instituição, oportunizando aos alunos deste nível de ensino, um modelo que garanta a escuta desses estudantes em suas demandas e expectativas, bem como que auxilie os professores da sala de aula regular em suas propostas de adaptações curriculares, através de avaliações especializadas dos processos de aprendizagem e das necessidades de acessibilidade dos estudantes.

- Elaborar projeto para organização da Sala de Recursos Multifuncional (SRM) em cada Campus, a qual deve ter espaço próprio e contemplar infraestrutura mínima para a realização de atendimentos individuais e em pequenos grupos, bem como dar conta da demanda específica de materiais didáticos adaptados para o ensino médio técnico, tais como Objetos de Aprendizagem já disponíveis e Aplicativos Adaptados, voltados para o ensino médio, construindo um banco virtual de material digital o qual poderá, inclusive, auxiliar nas adaptações curriculares do professores da sala de aula regular.

- Elaborar o Plano de AEE em cada Campus, o qual deverá contemplar os elementos considerados indispensáveis pela Política Nacional de Educação Especial na Perspectiva da Educação Inclusiva, de modo que sirva de sugestão para os demais Campi.

\section{CONSIDERAÇÕES FINAIS}

Diante do objetivo de visibilização da necessidade de institucionalização do AEE em nossa Instituição de Ensino, tem-se a ciência de que o mesmo vem sendo cumprido em nosso fazer cotidiano, através de cada atendimento realizado, de cada componente curricular ministrado, de cada evento em que nossa atuação é visibilizada.

Temos a convicção de que o AEE é resposta institucional significativa em prol de uma educação verdadeiramente inclusiva no referido Instituto Federal, tal qual pontam nossos princípios institucionais. E, como consequência última desta ação, a referida instituição de ensino poderá, finalmente, pensar em uma política institucional sólida de inclusão, a partir de uma perspectiva crítica de entendimento.

Crítica porque deve permanecer como um horizonte aberto de possibilidades para entendimento dos desafios reais que interferem nos processos de aprendizagem dos sujeitos humanos e, ao invés de olhar para as necessidades educacionais específicas, dedicando aos estudantes toda a responsabilidade neste processo, faríamos a opção consciente de olhar para esse fenômeno a partir de outro lugar, buscando entender as trajetórias dos estudantes na Institutição.

E para finalizar este trabalho, em relação as nossas expectativas para o futuro próximo, podemos afirmar que, diante da perspectiva da aprovação da Resolução que criará a política de AEE na Institutição, estamos otimistas, aguardando a oportunidade de fazermos a diferença em prol do princípio consittucional do direito de todos à educação. As sementes deste projeto já foram plantadas e temos certeza de que estão germinando em terra fértil!

\section{REFERÊNCIAS}

[1] Brasil. Constitutição Federal da República Federativa do Brasil. Presidência da República, Casa Civil: Brasília, 1988.

[2] Brasil. Decreto no 7611, de 17 de novembro de 2011. Dispõe sobre a educação especial, o atendimento educacional especializado e dá outras providências. Presidência da República, Casa Civil: Brasília, 2011.

[3] Brasil. Lei № 13.409 de 28 de dezembro de 2016. Altera a Lei no 12.711 , de 29 de agosto de 2012, para dispor sobre a reserva de vagas para pessoas com deficiência nos cursos técnico de nível médio e superior das instituições federais de ensino. Presidência da República, Casa Civil: Brasília, 2016.

[4] Brasil. Lei no 12.711 de 29 de agosto de 2012. Dispõe sobre o ingresso nas universidades federais e nas instituições federais de ensino técnico de nível médio e dá outras providências. Presidência da República, Casa Civil: Brasília, 2012. 
[5] Brasil. Lei no 11.892 de 29 de dezembro de 2008. Institui a Rede Federal de Educação Profissional, Científica e Tecnológica, cria os Institutos Federais de Educação, Ciência e Tecnologia, e dá outras providências. Presidência da República, Casa Civil: Brasília, 2008

[6] Brasil. Lei oo 9.394 de 1996. Lei de Diretrizes e Bases da Educação Nacional. Brasília: 1996.

[7] Cruz, Vítor. Dificuldades de Aprendizagem Específicas. Lidel, Portugal: 2009.

[8] Inep. Censo Escolar 2015. Brasília: 2015.

[9] Mantoan, M. T. E. Inclusão escolar: o que é? Por quê? Como fazer? 2ª ed., São Paulo: Moderna, 2007.

[10] Marchesi, Á.; Pérez, C. H. G. Fracasso Escolar: uma perspectiva multicultural. Porto alegre: Artmed, 2004.

[11] Mec. Nota Técnica Mec/Secadi no 106 de 19 de agosto de 2013. Orienta a Implementação da Política Institucional de Acessibilidade na Rede Federal de Educação Profissional, Científica e Tecnológica. Mec/Secadi: Brasília, 2013.

[12] Mec. Política Nacional de Educação Especial na Perspectiva da Educação Inclusiva. Mec/Secadi: Brasília, 2008.

[13] Mec. Resolução Cne/Ceb no 04 de 02 de outubro de 2009. Institui Diretrizes Operacionais para o Atendimento Educacional Especializado na Educação Básica, modalidade Educação Especial. Conselho Nacional de Educação: Brasília, 2009.

[14] Moysés, M. A. A. A Institucionalização Invisível: crianças que não-aprendem-na-escola. Campinas, 2ª ed., Mercado das Letras: 2014.

[15] Patto, M. H. S. A Produção do Fracasso Escolar: histórias de submissão e rebeldia. São Paulo: Casa do Psicólogo, 1999.

[16] Paz, C. T. N. A importância da avaliação pedagógica especializada de alunos com dificuldades de aprendizagem em Matemática: um estudo de caso. Revista Eletrônica da Matemática - Remat. IFRS, Bento Gonçalves, RS, Brasil, v. 4, n. 2, p. 01-05, dezembro de 2018.

[17] Ponte, J. P. Estudos de caso em educação matemática. Bolema: 2006.

[18] Yin, Roberto K. Estudo de caso: planejamento e métodos. 2a Ed. Porto Alegre. Editora: Bookmam. 2001. 


\section{Capítulo 19}

\section{Ensino de ciências com a abordagem da química verde na educação inclusiva}

\section{Monique Gonçalves \\ Fábio Dias de Oliveira Junior}

Resumo: A busca pela inclusão de alunos com Necessidades Educacionais Especiais (NEE) no sistema regular de ensino está em pauta nas diretrizes das políticas públicas em diversos níveis educacionais, sendo de suma importância que a aprendizagem se dê de forma total e ampla. A abordagem de trabalho com esses estudantes deve ser bem planejada e acompanhada, de modo a facilitar o ensino logo nos anos iniciais de escolarização.

Neste contexto, o professor e a escola tem grande importância, pois podem identificar estratégias metodológicas que garantam a aprendizagem do estudante, adaptando às características de cada um.

No entanto, ainda há docentes com dificuldades em lidar com essa questão em sala de aula; alguns reconhecem sua limitação, bem como a tendência involuntária em homogeneizar os alunos pelas práticas mais tradicionais de ensino. Essa é uma das razões pelas quais se deve investir na formação continuada do docente, bem como no preparo dos estudantes de licenciatura nos cursos de graduação por todo o Brasil.

Este trabalho foi desenvolvido por um licenciando em química em sua monografia, que se dedicou na elaboração de uma atividade lúdica destinada a um aluno com paralisia cerebral (PC). Buscou-se apresentar o ensino de Química pela abordagem da "Química Verde", com o tema transversal Meio Ambiente.

Foram usados como ferramenta pedagógica materiais recicláveis, propiciando uma prática sustentável, visando aprendizado prazeroso e abrangente entre os diferentes perfis de estudantes.

Palavras-chave: Educação inclusiva; Ensino de Ciências; Química Verde. 


\section{INTRODUÇÃO}

A educação inclusiva é frequentemente associada à participação de crianças com deficiência na escola regular, bem como aos alunos rotulados com necessidades educacionais especiais. Entretanto, o conceito de educação inclusiva é muito mais amplo do que a integração, e segundo a Organização das Nações Unidas, de forma geral, uma educação inclusiva e de qualidade baseia-se no direito que todos têm de receber uma educação que gere a aprendizagem ao longo da vida. "Um sistema educacional é de qualidade quando dá atenção aos grupos marginalizados e vulneráveis e procura desenvolver o seu potencial". (ONU, 2017)

A Organização das Nações Unidas para a Educação, a Ciência e a Cultura (UNESCO, 2017) define a educação inclusiva como um processo de identificação e resposta à diversidade das necessidades de todos os alunos através de uma maior participação na aprendizagem, culturas e comunidades, e reduzindo a exclusão na educação. Envolvem mudanças e modificações nos conteúdos, abordagens, estruturas e estratégias, com uma visão comum que inclui todas as crianças da faixa etária apropriada e a convicção de que é responsabilidade do sistema regular de ensino educar todas as crianças.

A Lei de Diretrizes e Bases da Educação, de 1996, em seu artigo 4º, inciso III dispõe ser dever do Estado dispor de uma educação escolar pública efetiva através da garantia de atendimento "educacional especializado gratuito aos educandos com deficiência, transtornos globais do desenvolvimento e altas habilidades ou superdotação, transversal a todos os níveis, etapas e modalidades, preferencialmente na rede regular de ensino" (BRASIL, 1996). Esse estudo se baseará na educação inclusiva para alunos com necessidades educacionais especiais (NEE).

A busca pela inclusão de alunos com NEE no sistema regular de ensino está na pauta das diretrizes das políticas públicas nos diversos níveis educacionais. São nítidas as implicações dessas políticas com a ampliação do acesso e inserção dos alunos com necessidade especiais em escolas regulares. Porém, alguns pontos devem ser levantados em relação a esse aumento no acesso à escola inclusiva, como a estrutura das escolas que recebem o aluno; a organização pedagógica, a disponibilidade de um intérprete e tutores, a preparação de professores e funcionários, entre outros. Mas é possível observar o ganho de espaço e priorização nos debates, trabalhos acadêmicos e a fortificação que esse tema tem tido ainda mais entre muitos educadores para que a verdadeira inclusão seja realizada. (BRASIL, 1996; RADMANN; PASTORIZA, 2016)

A LBI (Lei Brasileira de Inclusão), que entrou em vigor em julho de 2015, considera pessoa com deficiência aquela que tem impedimento de longo prazo de natureza física, mental, intelectual ou sensorial, o qual, em interação com uma ou mais barreiras, pode obstruir sua participação plena e efetiva na sociedade em igualdade de condições com as demais pessoas. (BRASIL, 2015)

As estratégias para a aprendizagem de uma pessoa com NEE devem ser planejadas e trabalhadas de modo a facilitar o ensino logo nos primeiros anos de escolarização, bem como deve ser acompanhando todo seu desenvolvimento. Por isso é importante ressaltar a grande importância do professor e da escola no desenvolvimento desse aluno, identificando as estratégias metodológicas que a instituição deve desenvolver para aprendizagem do estudante, pois o desafio é adaptar o ensino às características e necessidades de cada aluno.

Apesar da evolução, ainda é comum a inexistência de discussões a respeito da "necessidade dos docentes em lidar com essa nova questão em sala de aula, o que termina por levá-los a homogeneizar os alunos de maneira involuntária, apenas por não conhecer a necessidade educacional do seu aluno, provocando muitas vezes prejuízo ao seu aprendizado". (LIPPI; CAMARGO, 2009, p. 134)

É muito comum observarmos em sala de aula alunos descontentes com a maneira como as disciplinas de ciências são ensinadas. Os discentes afirmam ser de difícil entendimento, muito complexas e "fora da realidade".

Por esta razão defendemos que é de suma importância a preparação e formação de excelencia dos futuros profissionais da educação, abordando sempre nesse processo a importância da educação inclusiva e a formação continuada ao longo da vida profissional, tendo por base a realidade concreta onde se dão as aprendizagens. (VELTRONE, 2007, p. 52). Professores de alunos NEE apontam como principais dificuldades para a realização da inclusão escolar a falta de formação especializada durante a graduação, e de apoio técnico no trabalho. 
A química, enquanto uma disciplina das ciências naturais encontra-se inserida nesse contexto, com os alunos reclamando da grande dificuldade de entender o que é ensinado. Então, no caso particular do ensino de química e da Educação Inclusiva há muitos pontos de interseção:

"existem muitos aspectos de cunho teórico e metodológico a serem explorados, considerando a especificidade dos conteúdos ensinados, das suas formas de abordagem e da linguagem química, de modo a incluir efetivamente os alunos com necessidades especiais". (SCHUINDT et. al., 2016, p. 2).

Dentro desse contexto podemos explorar o coceito da Química Verde, uma nova forma filosófica de se pensar e fazer química definida por Anastas e Warner (1998), que aborda um conjunto de princípios que reduz ou elimina o uso ou a geração de substâncias perigosas na concepção, fabricação e aplicação de produtos químicos. A química verde segundo a American Chemical Society (2017) se liga ao conceito de química ecológica, uma ideia relativamente nova, que se desenvolveu nas comunidades empresariais e reguladoras como uma evolução natural das iniciativas de prevenção dos recursos naturais e redução da poluição. Em nossos esforços para melhorar a proteção de culturas, produtos comerciais e medicamentos, também causamos danos não intencionais ao nosso planeta e à espécie humana.

Assim, a Química Verde anda de mãos dadas com a Educação Ambiental, e na atual conjuntura de problemas ambientais que tem acontecido no mundo, cujo impacto das ações do homem tem grande parcela de culpa, torna-se fundamental promover junto aos alunos uma visão abrangente sobre essa situação, e ajudá-los a entender os assuntos abordados nas aulas de química, e suas relações com o meio ambiente. Através dos estudos dos fenômenos químicos e físicos ocorridos na natureza como processos endotérmicos e exotérmicos, mudanças de estados físicos da matéria, evapotranspiração e fotossíntese é possível apontar onde a química verde pode ser inserida dentro do contexto do ensino da química de forma continuada". (MARQUEZ; SILVA, 2008, p. 1)

A partir do que foi exposto, surge o seguinte questionamento:

Qual a possível abordagem e contribuição da química verde no ensino das ciências dentro da educação inclusiva?

Buscando responder essa pergunta, o presente trabalho, fruto do trabalho de conclusão de curso de um estudante de licenciatura em química, tem como principal objetivo apresentar o ensino de Ciências com a abordagem da Química Verde na Educação Inclusiva. Para isso, será abordado a Educação Inclusiva e o papel do educador frente aos alunos com NEE.

Esse trabalho se justifica pela relevância do tema para a sociedade, para a pessoa com algum tipo de deficiência e para o professor que trabalha com a inclusão desses alunos. A educação inclusiva ao acolher a pessoa com deficiência, reconhecendo todas as suas possibilidades, está ajudando a preparar uma futura emancipação que trará benefícios para todos.

\section{OBJETIVOS}

\subsection{OBJETIVO GERAL}

Apresentar o ensino da Química Verde, na educação inclusiva, sua ligação com a educação ambiental e sua importância, utilizando como tema transversal o Meio Ambiente.

\subsection{OBJETIVOS ESPECÍFICOS}

Abordar a aplicação da Química no cotidiano, a fim de que o aluno se interesse mais pela disciplina e pela ciência, em geral, adquira conhecimento a partir daquilo que ele já conhece.

Aproximar os alunos de temas que tangem diversas disciplinas a partir do Ensino de Química de modo interdisciplinar.

Mostrar que a inclusão é possível, e para isso o uso do método lúdico no ensino de ciências apresenta-se como um auxiliador, pois é uma ferramenta rica que propicia um aprendizado prazeroso. 


\section{FORMACTÃO CONTINUADA DO PROFESSOR DE CIÊNCIAS}

Com a implantação da atual Lei de Diretrizes e Bases, e a clara intenção do princípio inclusivo que fundamenta a adoção e a implementação de currículos abertos e flexíveis, que atendam à diversidade do alunado presente na escola, passou a ser objeto de discussão nas diretrizes curriculares e nos cursos de formação continuada dos sistemas de ensino o conceito da Escola Inclusiva.

Conforme as Diretrizes Curriculares Nacionais para Educação Especial (MEC/SEESP, 1998), implica uma nova postura da escola comum, que propõe no projeto político pedagógico, no currículo, na metodologia de ensino, na avaliação e na atitude dos educandos, ações que favoreçam a integração social e sua opção por práticas heterogenias. A escola capacita seus professores, organiza-se e adapta-se para oferecer educação de qualidade para todos. Inclusão, portanto, não significa simplesmente matricular os educandos com NEE na classe comum, - ignorando suas necessidades especificas, mas significa dar ao professor e a escola o suporte necessário à sua ação pedagógica.

Sendo assim, a educação especial e inclusiva já não é mais concebida como um sistema educacional paralelo ou segregado, mas como um conjunto de medidas que a escola regular põe ao serviço de uma resposta adaptada à diversidade dos alunos. Neste contexto, a instituição escolar passa a ser alvo de questionamentos e de conflitos, provavelmente, por expor a diversidade e o compartilhamento de interesses, contradições, expectativas e identidades. Muitas são as ansiedades que movimentam as transformações em busca do que se julga ser o ideal, correspondendo às necessidades específicas de todos. Para atender esta demanda a escola deve promover mudanças, de modo que consiga possibilitar a todos um ensino de qualidade que respeite as diferenças e especificidades do ser humano, ou seja, na perspectiva da inclusão não é o aluno que se adapta ao ensino e sim a escola que deve promover meios para que este aluno acesse ao conhecimento. (RETONDO, 2008)

\section{QUÍMICA VERDE}

A química verde surgiu de uma variedade de ideias existentes no período precedente a década de 1990, sob o contexto da crescente atenção aos problemas de poluição química e depleção de recursos. 0 desenvolvimento da química verde na Europa e nos Estados Unidos foi vinculado a uma mudança nas estratégias ambientais de resolução de problemas, através de um movimento de controle e redução obrigatória de emissões industriais para a prevenção ativa de poluição por meio do design inovador das próprias tecnologias de produção. (CLARK, 2012)

Química verde refere-se a um plano de ação, que pensa produtos e procedimentos químicos que diminuem ou extinguem o uso de substâncias nocivas. É uma linha de raciocínio que tem se difundido cada vez mais, a fim de fazer com que a química se torne uma aliada ao meio ambiente. A ampliação de novos compostos sintéticos, por meio de reações químicas, trouxe uma nova forma de viver, porém trouxe diversas implicações, como impactos ambientais irreversíveis, pois muitos dos produtos desenvolvidos são de difícil decomposição, além de causar danos à saúde do ser humano. (CLARK, 2012)

Também chamada de "Química sustentável", pode ser entendida pela gestão de impactos ambientais, sociais e econômicos ocasionados pela atividade química no meio ambiente, na qual todas as partes envolvidas se beneficiam e os recursos naturais suprem as necessidades atuais e futuras da humanidade. Assegurar a qualidade de vida em todo o planeta também é uma das principais filosofias da química verde, que acredita que devem ser criados padrões para reduzir ou eliminar o uso e a geração de substâncias nocivas. Segundo Anastas, P. T. e Warner, J., (2000), os doze princípios básicos da química verde ou sustentável são:

1. é melhor prevenir que tratar ou limpar resíduos de processos químicos depois de formados;

2. métodos sintéticos devem ser projetados para maximizar a incorporação de toda a massa dos reagentes no produto, minimizando os rejeitos;

3. as metodologias utilizadas devem usar e gerar substâncias o menos tóxicas possíveis à vida humana e ao ambiente;

4. os produtos químicos devem ser projetados de forma a ter maior eficiência e menor toxidez;

5. o uso de substâncias como solventes, deve, sempre que possível, ser desnecessário ou inofensivo quando usado; 
6. as exigências energéticas devem ser reconhecidas por seus impactos ambientais e econômicos e precisam ser minimizadas. Métodos sintéticos devem, sempre que possível, ser conduzidos em temperatura e pressão ambientes;

7. a matéria-prima deve ser proveniente de fontes inesgotáveis (renováveis);

8. deve-se desenhar a metodologia de modo a não precisar de derivatizações como grupos de proteção;

9. reagentes catalíticos são sempre superiores a reagentes estequiométricos;

10. os produtos químicos devem ser desenhados de tal maneira que, depois de terem sido usados, eles não persistam no ambiente e que seus produtos de degradação sejam inócuos;

11. métodos analíticos devem ser desenvolvidos para monitorar o processo em tempo real controlado, a priori, a formação de substâncias perigosas;

12. as substâncias e a forma como são usadas no processo químico devem minimizar o potencial de acidentes.

A química verde se concentra em abordagens tecnológicas para prevenir a poluição e reduzir o consumo de recursos não renováveis. Sobrepõe-se a todas as subdisciplinas de química, mas com um foco particular na síntese química, química de processo e engenharia química, e em aplicações industriais. Em menor grau, os princípios da química verde também afetam as práticas nos laboratórios. 0 mais importante é saber que a busca pela sustentabilidade é uma solução para amenizar a escassez de alguns recursos naturais, melhorar a qualidade de vida e garantir que o planeta ofereça condições de sobrevivência por várias gerações.

\subsection{ENSINO DA QUIMICA VERDE NA EDUCAÇÃO INCLUSIVA}

O planeta Terra passou por várias reações químicas, as naturais e as causadas pela intervenção do homem, conhecidas como antrópicas. Obviamente, esses fenômenos ocasionam vários resultados e muitos deles são prejudiciais, como, por exemplo, a poluição do ar, da água e do solo; o aquecimento global, as mudanças na camada de ozônio e diversas ações que alteraram o ciclo natural do meio ambiente.

Essas questões ambientais fazem parte das notícias na televisão, jornal, rádio e internet, e tornaram-se cada vez mais alarmantes cotidianamente na vida da população. Muitas pessoas percebem que a química e a indústria química estão envolvidas nessa situação que é prejudicial ao meio ambiente, a "química e o meio ambiente estão intimamente ligados, uma vez que o planeta vem sendo atingido por vários problemas que correspondem a esse campo do conhecimento". (PARANÁ, 2008, p. 55)

No entanto, novos avanços e pesquisas científicas no campo da química estão ajudando a desenvolver materiais e aplicações mais amigáveis a o ambiente. E nesse contexto tem-se a química verde, que é considera sinônimo de sustentabilidade, onde se busca encontrar novas maneiras de se obter produtos menos agressivos o meio ambiente.

A química verde é uma importante ferramenta para que o aluno compreenda os conceitos científicos, possa entender o mundo e mudar a sua atitude diante dele. Nesse sentido, e da perspectiva dos processos didáticos inerentes ao ensino da química, é possível detectar as dificuldades em seus ensinamentos, o que provoca desinteresse e certas atitudes negativas dos estudantes em relação ao estudo da disciplina. Isso está relacionado aos modelos de ensino tradicionais que indicam concepções dogmáticas sobre ciência e descontextualizados com temas de interesse atual.

No ensino elementar os Parâmetros Curriculares Nacionais de Ciências Naturais indicam como eixos temáticos Vida e Ambiente; Tecnologia e Sociedade, que apresentam uma variedade de conteúdos que podem auxiliar na introdução de diversos conceitos de química. No eixo Vida e Ambiente, observam Silva; Núñes podem ser trabalhados os seguintes conteúdos:

"estabelecimento de relações entre fenômenos da fotossíntese, da respiração celular e da combustão para explicar os ciclos do carbono e do oxigênio de forma integrada ao fluxo unidirecional de energia do planeta; - investigação dos fenômenos de transformação de estados físicos da água ocorridos em situações de experimentação e na natureza, em que há alteração de pressão e temperatura, compreendendo o ciclo da água em diferentes ambientes e o modo como os mananciais são reabastecidos; • investigação de alterações de determinados ambientes 
como resultado da emissão de poluentes, compreendendo os processos de dispersão no planeta e os aspectos ligados à cultura e à economia para valorizar medidas de saneamento e de controle da poluição". (2007 apud BRITO, 2014, p. 19)

Observa-se que alguns desses conteúdos podem ser relacionados com a química verde, que tem como proposta apresentar soluções técnicas e científicas para os problemas ambientais, como por exemplo, o controle da poluição. A química verde é de muita importância, pois busca eliminar "os riscos ao meio ambiente e aos seres humanos, quando ocorre o uso de substâncias e processos químicos que possuem potencial poluente ou risco ambiental". (BRITO, 2014, p. 22)

Um dos maiores obstáculos no ensino de química para alunos com deficiência, além da falta de professores com formação adequada, é que as asserções educacionais se baseiam no referencial perceptual da visão e são acompanhadas da ausência de estímulos, da falta de acessibilidade nos laboratórios, de recursos didáticos ineficazes e pela escassez de informações que acentuam a passividade desses alunos nas aulas. (BRITO, 2014, p. 25)

Uma das formas de ensinar a química verde aos alunos com deficiência é através dos jogos didáticos. 0 uso do lúdico nos ensinos Fundamental e Médio são práticas excelentes para auxiliar uma educação que visa o desenvolvimento pessoal do aluno, despertar seu interesse em sala de aula, ajudar no aprendizado, criar uma ligação com o professor e os demais alunos. 0 jogo pode ajudar significativamente no processo de construção do conhecimento de química para o aluno, transformando-o em mediador da própria aprendizagem, além de ser uma fonte de prazer e descoberta. (MELO, 2011)

\section{METODOLOGIA - JOGO DIDÁTICO: "OBSERVE, MIRE E PENSE"}

A ideia do jogo "Observe, Mire e Pense" surgiu a partir de um vídeo disponibilizado no Youtube, que traz um trabalho elaborado por um grupo de estudante do curso de Ciências Biológicas da Universidade Estadual do Ceará para a disciplina Ecologia. O grupo propôs o jogo Trampolim da poluição ambiental para ser utilizado no 7o ano do ensino fundamental, tratando de questões sobre poluição. Após ver o vídeo, observei que com as adaptações corretas o jogo poderia ser utilizado por alunos com necessidades especiais.

O objetivo do jogo é incentivar a reflexão e a discussão sobre temáticas ambientais de forma lúdica. 0 jogo atinge a diferentes públicos, sua adaptação é feita para atender aos alunos com as deficiências: físicas, visual e auditiva. Tendo por base a temática sustentabilidade, a proposta do jogo é de conscientizar e testar os saberes dos alunos sobre os assuntos previamente trabalhados em sala de aula. Ele traz em sua essência todo o conceito, importância e conscientização da sustentabilidade, desde a confecção de seu tabuleiro.

Foram utilizados materiais reciclados na confecção do jogo, mostrando que existe a possibilidade de criar a partir de algo que iria para o lixo, e então estimular o instinto de criatividade em projetos futuros na vivência escolar. Os materiais utilizados na confecção do jogo foram: caixa de ovos, EVA, cola, bolinha de ping pong, arroz, papelão, tampinha de garrafa.

A caixa de ovos se transforma no tabuleiro do jogo, e as fichas são feitas de EVA colorida no intuito de prender a a atenção do aluno. Os números e símbolos presentes nas fichas foram feitas em alto relevo e em braile e a cada número corresponde uma pergunta previamente definida pelo professor sobre um assunto que já tenha sido tratado em aula. 
Figura 3: Jogo "Observe, Mire E Pense".

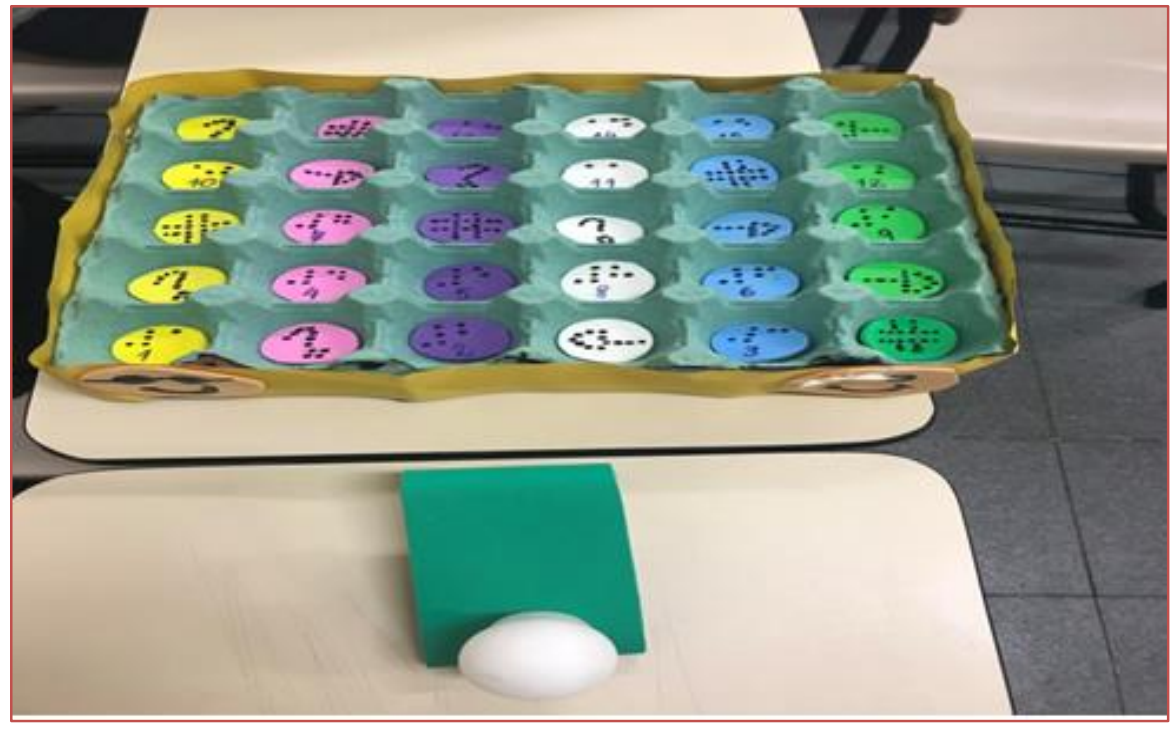

Fonte: Autor, 2017.

Figura 4: Jogo “Observe, Mire E Pense”.

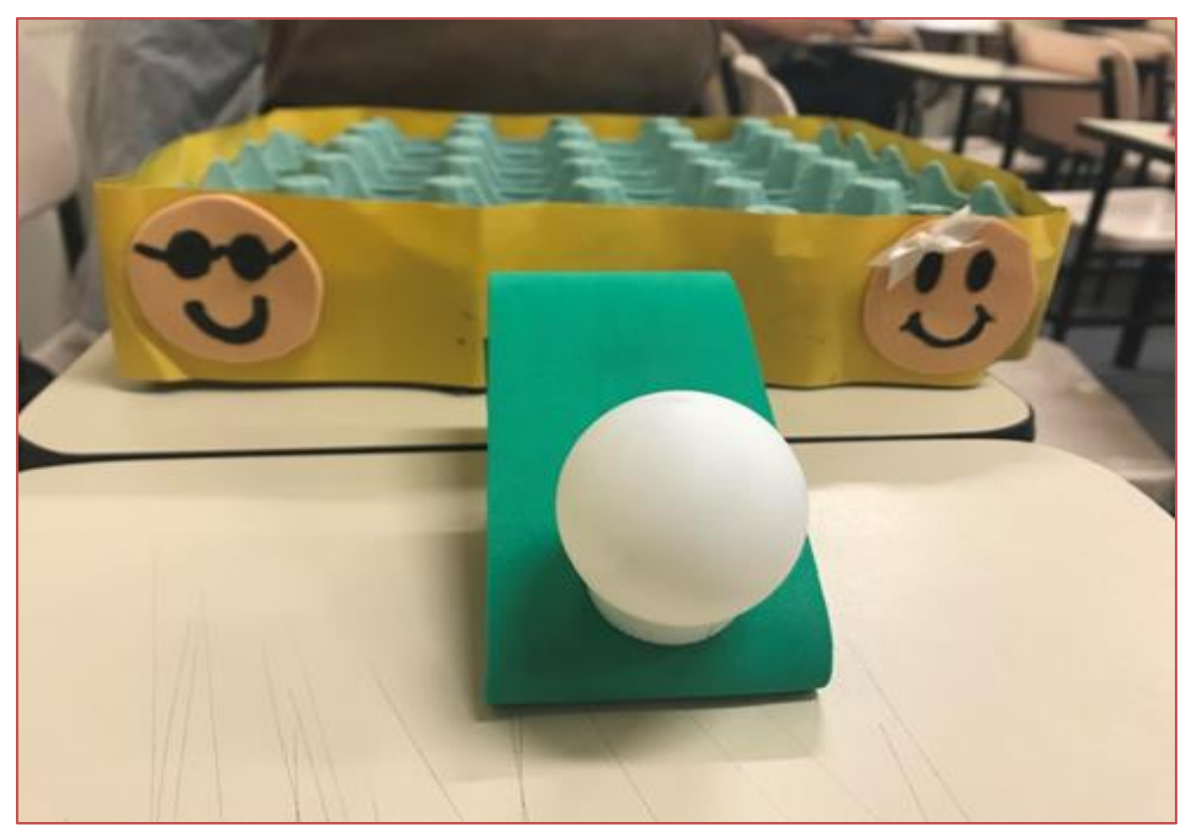

Fonte: Autor, 2017.

\section{RESULTADOS E DISCUSSÕES}

O jogo começou com a divisão da turma em grupos de no máximo 5 alunos. Ao posicionar a "gangorra" com a bolinha de ping pong em sua extremidade, o aluno pressiona a gangorra e a bolinha pega impulso e se direciona em direção ao tabuleiro; neste há espaços com números ou símbolos. A bolinha deverá cair em algum desses espaços e o mediador da atividade irá verificar onde a bolinha caiu. Se tiver caído sobre um número a pergunta correspondente ao número será feita ao aluno. As perguntas são retiradas do conteúdo já ministrado anteriormente em aula. Ao acertar a pergunta o aluno retira a ficha do tabuleiro e soma a pontuação da ficha.

Os símbolos: 
As setas significam passar a vez. Quando o participante jogar a bolinha e esta cair nesta casa da seta, ele deverá passar a vez para outro aluno do grupo.

\# - 0 jogo da velha significa que o participante deve ficar uma rodada sem jogar. Se a bolinha cair na casa do jogo do velho, o aluno fica a próxima rodada sem jogar.

? - O símbolo interrogação significa alguma atividade sugerida pelo mediador (professor), pode ser um desafio, um mico, uma dança, etc.

Seguiu-se padrões de adaptação para atender a qualquer aluno com as necessidades visuais, físicas e auditivas. $\mathrm{O}$ tabuleiro foi adaptado para alunos com deficiência visual (todas as peças com símbolos ou números em braile, feito com cola de alto relevo). 0 fato de o tabuleiro ter sido transformado através de uma caixa de ovos, também foi pensado para que o aluno deficiente visual pudesse usufruir do tato para sentir todo e qualquer formato dos materiais. Com relação a bolinha de ping-pong, foi colocado dentro dela grãos de arroz, para que ela pudesse ter som e assim ser acessível ao aluno deficiente visual.

O jogo foi aplicado em uma exposição de trabalhos, realizada no Curso de Pedagogia na Faculdade Souza Marques. Uma das alunas do curso de Pedagogia participou da atividade e jogou o "Observe, Mire e Pense", conseguindo realizar todos os procedimentos do jogo. A aluna possui limitações físicas e motoras, porém conseguiu compreender todas as regras e participar do jogo proposto.

Figura 5: Aluna jogando "Observe, Mire E Pense”.

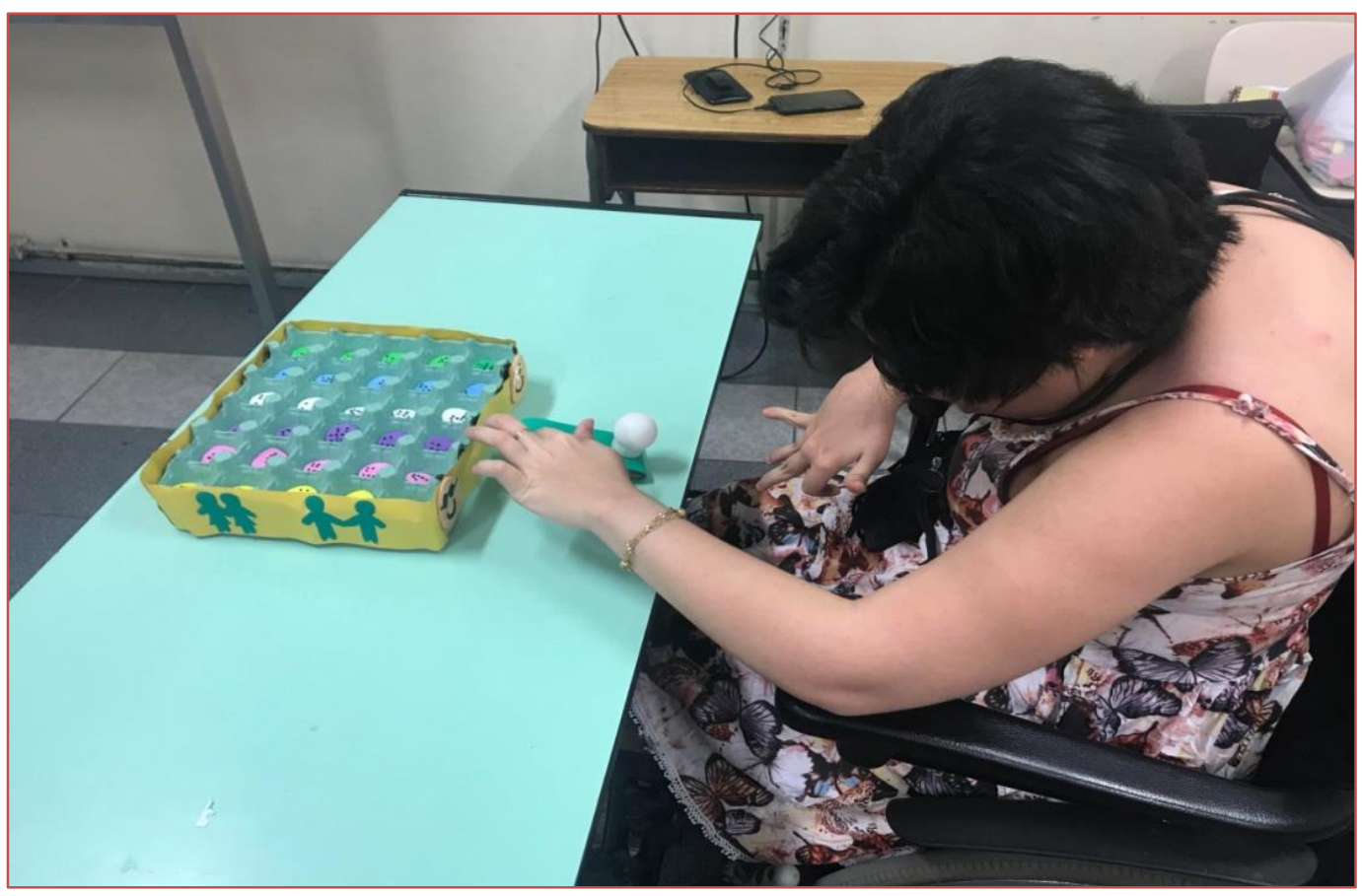

Fonte: Autor, 2017. 
Figura 6: Aluna jogando "Observe, Mire E Pense".

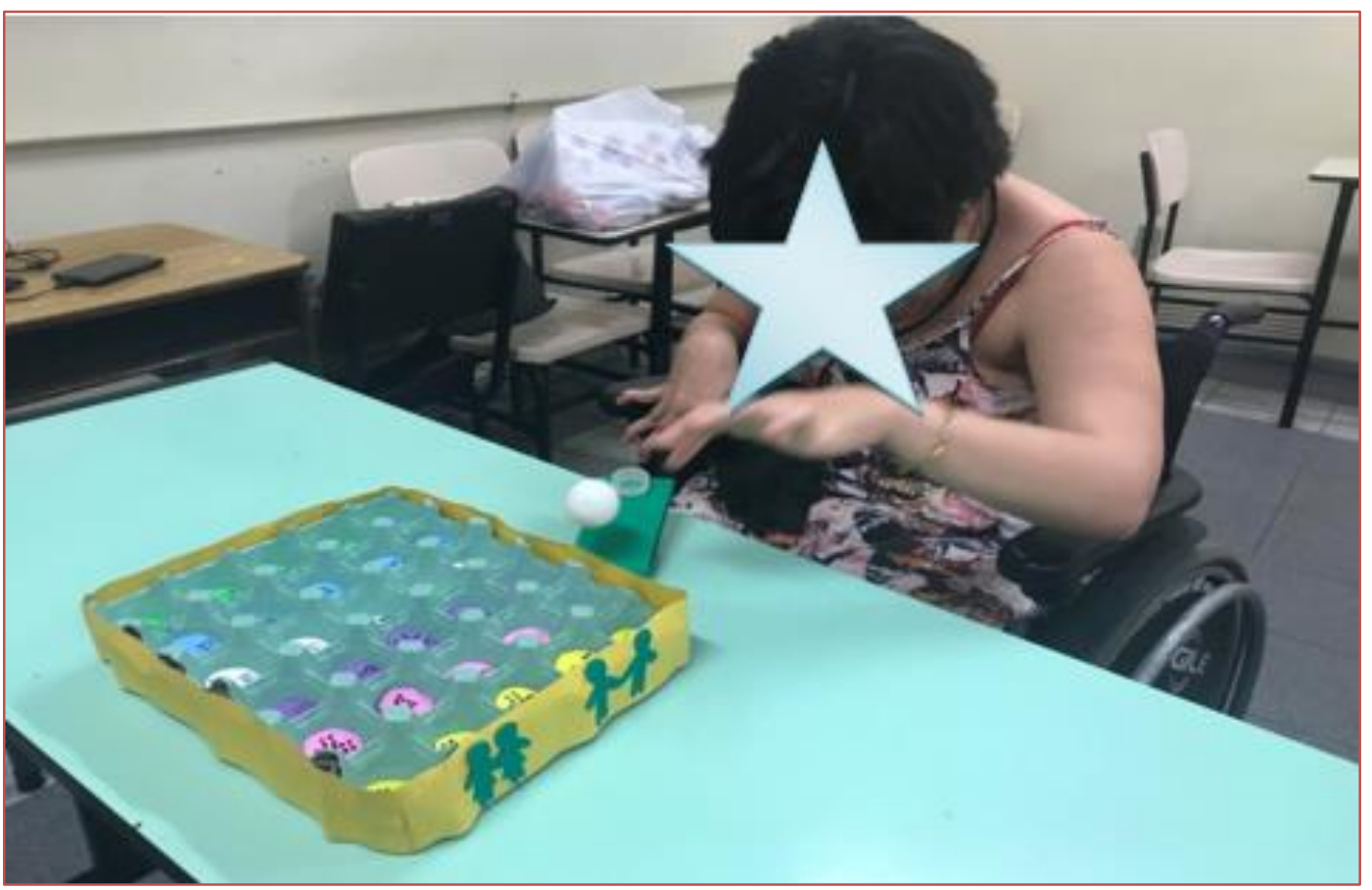

Fonte: Autor, 2017

\section{CONCLUSÃO}

O estudante com NEE têm muito a aprender, e muito a nos ensinar. Desde que saibamos trabalhar o potencial que eles possuem, pode-se realizar um trabalho gratificante e adequado. Conforme o que fora exposto na presente pesquisa, faz-se necessário administrar a prática de tal forma que a ação pedagógica não acentue a incapacidade de quem não aprende, mas que se encontre uma maneira adequada de aprender a singularidade de cada um.

Estudantes com dificuldades de aprendizagem apresentam baixa autoestima, se sentem incapazes. Portanto, é necessário trabalhar com entusiasmo e ter a clareza daquilo que precisa para sentir-se capaz de entender. Esses alunos são capazes de expandir sua aprendizagem e seu potencial cognitivo. É imprescindível que as pessoas envolvidas em seu processo de aprendizagem não desistam de encontrar maneiras de ensinar.

Com o desenvolvimento da pesquisa foi verificado o quanto é importante o professor ter uma formação mais completa, uma especialização, para melhor atender seus alunos, e reafirma que as instituições devem estar preparadas para receber alunos com NEE.

A ideia da atividade lúdica é aproximar o aluno da realidade com a proposta do conteúdo programático trabalhado. Trabalhar a disciplina química com o tema meio ambiente é uma forma interdisciplinar de conduzir os conteúdos e mostrar que a atividade lúdica pode ser abordada em qualquer disciplina no ambiente escolar. A utilização do tema "meio ambiente" pode ser interligado e associado de várias formas dentro dos conteúdos programáticos no ensino de química.

A busca pela inclusão foi realizada em todas as etapas da atividade, focando a concentração dos alunos, independente de limitações existentes em alguns alunos desta sala de aula, mostrando que todos são capazes de realizar as atividades e assimilar o conteúdo posposto pela atividade lúdica. Também trouxe para o aluno que não possui NEE uma experiência diferente, desenvolvendo o respeito mútuo no ambiente escolar, realizando assim, da forma mais proveitosa possível, a inclusão educacional. 


\section{REFERENNCIAS}

[1] AMERICAN CHEMICAL SOCIETY What is green chemistry?, 2017. Disponível em:< https://www.acs.org/content/acs/en/greenchemistry.html>.

[2] ANASTAS, P. T.; WARNER, J. Green Chemistry: Theory and Practice. Oxford University Press: Oxford, 1998, $160 \mathrm{p}$.

[3] ANASTAS, P. T.; WARNER, J. C. Green Chemistry: Theory and Practice. Oxford University Press: Great Britain, cap. 9, p. 94-95, 2000.

[4] BATISTA, C. A. M. e MANTOAN, M. T. E. Atendimento educacional especializado em deficiência mental. In: GOMES, A. L. L. et. al. Deficiência mental. São Paulo: MEC/SEESP, 2007.

[5] BENITE, A.M.C.; PEREIRA, Jorge. Formação do professor e docência em química em rede social: estudos sobre inclusão escolar e o pensar comunicativo. Tese do Programa Multiinstitucional de Doutorado em Química UFG/UFU/UFMS - Goiânia, GO, Brasil.

[6] BRASIL, Ministério da Educação Secretaria de Educação Fundamental. Programa de desenvolvimento profissional continuado: alfabetização, 1999.

[7] __. Lei no 9.394, de 20 de dezembro de 1996. Estabelece as diretrizes e bases da educação nacional. Diário Oficial da União, Brasília, DF, 21 dez. 1996.

[8] ___ Lei no 13.146, de 06 de julho de 2015. Institui a Lei Brasileira de Inclusão da Pessoa com Deficiência (Estatuto da Pessoa com Deficiência). Diário Oficial da União, Brasília, DF, 07 jul. 2015.

[9] ___. Secretaria Especial de Dos Direitos da Pessoa com Deficiência. Legislação. 2017.

[10] BRITO, Soraia. Ensino de ciências na educação fundamental. Rio de Janeiro: Editora Unirio, 2014.

[11] CLARK, J. H.; LUQUE, R.; MATHARU, A. S. "Green Chemistry, Biofuels, and Biorefinery, 2012.

[12] ESTADO DO PARANÁ. Química Verde - uma temática ambiental no ensino de Química. 2008.

[13] LIPPE, Eliza Márcia Oliveira; CAMARGO, Eder Pires de. 0 ensino de ciências e seus desafios para a inclusão: o papel do professor especialista. In: NARDI, R. (Org.). Ensino de ciências e matemática, I: temas sobre a formação de professores. São Paulo: Editora UNESP; São Paulo: Cultura Acadêmica, 2009.

[14] MARQUEZ, K. S. G.; SILVA, P. C. da. A importância dos conceitos de química verde no ensino de química. In: Encontro Nacional de Ensino de Química. Curitiba: UFPR, 2008.

[15] MELO, Edina Souza de. Atividades experimentais na escola. Revista Virtual P@rtes, fev. 2011. <http://www.partes.com.br/educacao/experimentais.asp>.

[16] MEC/SEESP, 1998, http://portal.mec.gov.br/

[17] ORGANIZAÇÃO DAS NAÇÕES UNIDAS. Educação inclusiva. 2017. < https://nacoesunidas.org/tema/ods4/>.

[18] ORGANIZAÇÃO DAS NAÇÕES UNIDAS PARA A EDUCAÇÃO, A CIÊNCIA E A CULTURA. Educação inclusiva.

2017.

[19] RADMANN, T.; PASTORIZA, B, S. Educação Inclusiva no ensino de Química. In: XVIII Encontro Nacional de Ensino de Química. 2016, Florianópolis.

[20] RETONDO, C. G.; SILVA, G. M. Ressignificando a formação de professores de Química para a educação especial e inclusiva: uma história de parcerias. Revista Química Nova na Escola, n.30, p. 27-33, nov. 2008.

[21] SCHUINDT et. al., 2016. A educação inclusiva e a dificuldade de aprendizagem no ensino de ciências/química. ACTIO, Curitiba, v. 2, n. 1, p. 282-303, jan./jul. 2016.

[22] UNESCO, 2017, https://nacoesunidas.org/agencia/unesco/

[23] VELTRONE, Aline. A formação docente na perspectiva da inclusão. IX Congresso Estadual Paulista sobre Formação de Educadores. Universidade Estadual Paulista (UNESP), São Paulo, 2007. 


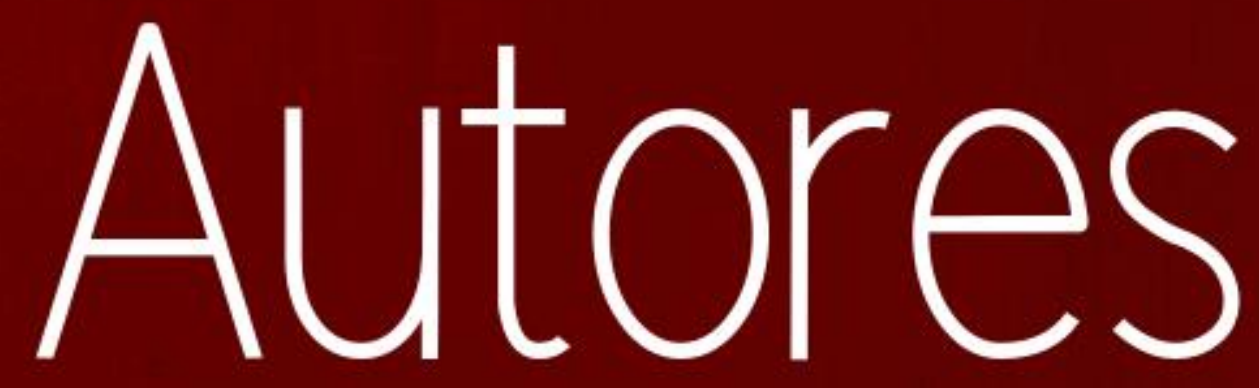




\section{ADRIANA PIRES DE AREZZO}

Possui Mestrado em Sociologia pelo Instituto Universitário de Pesquisas (IUPERJ), Graduação em Ciências Sociais pela Universidade Federal Fluminense (UFF) e em Ciências Biológicas pela Faculdade Pedro II (FAHUPE). Cursou pós graduação em Planejamento Ambiental e Metodologia do Ensino Superior pela Universidade Federal Fluminense (UFF). Atualmente é professora assistente no Centro Universitário La Salle/RJ, nos cursos de Direito, Pedagogia e Sistemas de Informação; e professora do Ensino Médio no ensino Público e privado do município de Niterói. Desenvolve pesquisas nas áreas de sociologia da educação; sociologia jurídica; metodologias de ensino em ciências naturais; educação ambiental e formação de professores.

\section{ALAIM SOUZA NETO}

Pós-Doutorado e Doutorado em Educação pela UFSC e UDESC. Professor do Departamento de Ciências Exatas e Educação, do Programa de Pós-Graduação em Métodos e Gestão em Avaliação (PPGMGA) e do Programa de Mestrado Profissional em Letras (PROFLETRAS) da UFSC. É líder do Grupo de Pesquisa Observatório de Práticas Curriculares, relacionando os campos do Currículo, Formação Docente e Tecnologias, além de membro pesquisador do Grupo OPE - Observatório de Práticas Escolares da UDESC. Suas pesquisas têm sido voltadas para o campo do Currículo, Formação de Professores, Avaliação e Gestão da Educação, Cultura Digital e Inovação Pedagógica, problematizando a Integração de Tecnologias na Cultura Escolar.

\section{ANA CAROLINA SALES OLIVEIRA}

Graduada em Fonoaudiologia pela Pontifícia Universidade Católica de Campinas (2005) e em Pedagogia pela Universidade Paulista (2014). Tem Especialização em Linguagem pela Faculdade de Ciências Médicas da Santa Casa de São Paulo, Especialização em Informática em Educação pela Universidade Federal de Lavras, Especialização em Libras pela Faculdades Integradas de Jacarepaguá, Especialização em Audiologia pelo CEFAC e Especialização em Neuropsicopedagogia pelo Centro Universitário Leonardo Da Vinci. É Mestra e Doutora em Ciências da Linguagem (CAPES 4) pela Universidade do Vale do Sapucaí. É professora das disciplinas de Libras, Filosofia da Educação e Linguagem e Comunicação na Universidade Federal de Itajubá. Tem experiência nas áreas de ensino inclusivo e Libras.

\section{ANA PAULA SILVA DE SOUZA}

Graduada em Ciências Agrárias pela Universidade (2014) Federal da Paraíba, e em Pedagogia pela Universidade Estadual da Paraíba-UEPB(2019). Atuo como professora de sala de AEE nos municípios Sapé e Mari-PB. Especialização em Psicopedagogia Clínica e Institucional. Estou em constante formação para assim melhor atender os alunos. Cursos na área de deficiência, Braille(2019) Libras em 2010, Atendimento Educacional Especializado para professores(2016) Buscando competências para Incluir (2013), oferecidos pela FUNAD- PB, Curso de extensão Educação em TEA- Transtorno do Espectro Autista (UFRJ, 2019), Atendimento Educacional Especializado em Altas Habilidades/Superdotação (FACED da UFU-MG, 2015), Curso de Língua de Sinais Brasileira- Libras na perspectiva da Educação Bilíngue (ILEEL da UFU-MG, 2018) Atualmente estou cursando Especialização em Libras pelo IFPB-PB.

\section{ANNA LÚCIA SAMPAIO MARCHESINI}

Psicóloga formada pela Escola Bahiana de Medicina e Saúde Pública (2005). Mestre em Psicologia Clínica pela PUC/SP (2010). Docente nos cursos de Graduação e Pós - graduação e Psicóloga atuante em clínica e educação. 


\section{ARTUR JOSÉ BRAGA DE MENDONÇA}

Graduado em administração, Especialização em Orientação e Mobilidade e em Docência do Ensino Superior. 23 anos de dedicação à Inclusão de Pessoas com Deficiência. Experiência em elaboração, execução e gestão de projetos de acessibilidade voltados ao segmento de Pessoas com Deficiência. Professor Braillista (ensino do Sistema Braille) e professor especialista de Orientação e Mobilidade (para pessoas com deficiência visual). Atuação em Docência - 9 anos - (pós-graduação, graduação, nível técnico e EAD). Na pós-graduação ministro as disciplinas relacionadas à inclusão de pessoas com deficiência. Atuo como Professor especialista de Orientação e Mobilidade desde 1998 e desde 2015 estou como voluntário no Instituto de Cegos do Recife/PE prestando serviços como professor de Orientação e Mobilidade. Coordenei alguns projetos de Acessibilidade entre eles: "Pesquisa sobre calçadas" - para o Instituto de Pesquisa Maurício de Nassau/PE; "Inclusão profissional e acessibilidade" - para a Superintendência Estadual de Apoio à Pessoa com Deficiência do Governo do Estado de Pernambuco; "Pesquisa sobre Acessibilidade nos Parques" - para a Prefeitura do Recife/PE; "Cão Guia" - para o KENNEL Clube de Pernambuco; "Levantamento das condições de inacessibilidade em hotéis, pousadas e similares"; "Diagnóstico de acessibilidade em Instituição de Ensino Superior"; e outros. Experiência em coordenação e ensino nos cursos de formação para o atendimento à pessoa com deficiência visual. Tenho experiência profissional de 32 anos em Gestão Pública.

\section{CAIO VINICIUS DOS SANTOS}

Discente, nível mestrado, do Programa de Pós-Graduação em Educação Escolar da Faculdade de Ciências e Letras (FCL) da Universidade Estadual Paulista (UNESP), Campus de Araraquara. Possui graduação em História/Licenciatura pela Universidade Federal de Mato Grosso do Sul (UFMS). Atua na linha de pesquisa Formação de Professor, Trabalho Docente e Práticas Pedagógicas. Participa do Grupo de Estudos e Pesquisas na Educação Básica- Educação Especial - GEPEB- EDESP, desenvolvendo pesquisas voltadas a formação inicial de professores e a temáticas sobre Educação Especial.

\section{CIBELE MOREIRA MONTEIRO}

Graduada em Letras (2001) pelo Centro Universitário de Itajubá, mantido pela Fundação de Ensino e Pesquisa de Itajubá - Fepi, mestra em Estudos Literários (2004) pela Universidade Estadual Paulista Júlio de Mesquita Filho - Unesp e doutoranda em Educação pela Universidade São Francisco - USF. É professora da Universidade Federal de Itajubá - Unifei e membro do Grupo de Pesquisa Relações de Ensino e Trabalho Docente da USF.

\section{CLÁUDIA MEDIANEIRA ALVES ZIEGLER}

Pedagoga e psicopedagoga. Atualmente é técnica pedagoga junto do IFRS, Campus Farroupilha.

\section{CLÁUDIA TERRA DO NASCIMENTO PAZ}

Professora pedagoga, educadora especial e psicopedagoga, doutora em educação pela UFRGS. É docente efetiva do IFSC, Campus Tubarão, atuando nas áreas de psicopedagogia, educação especial e processos de ensino e aprendizagem. 


\section{DÉVERSON ROGÉRIO RANDO}

Mestre em Ciência da Computação pela Universidade Estadual de Maringá (UEM), Especialista em Engenharia de Software pela Universidade Norte do Paraná, Graduado em Geografia pela Universidade Estadual de Londrina, tecnólogo em Análise e Desenvolvimento de Sistemas pelo CESUMAR e bacharel em Sistemas de Informação pela FAP. Coordenador do Curso de Bacharelado em Sistemas de Informação da FAP-Faculdades Aoucarana, professor do curso de Ciência da Computação na UNESPAR Apucarana e professor dos cursos de Técnico em Redes e Informática respesctivamente no SENAC e SENAI nas disciplinas de Banco de Dados, Análise Estruturada e 00, Organização e Arquitetura de Computadores, Computação Gráfica, IHC, Algorítmos, Linguagens de Programação, Sistemas de Informações Geográficas, Trabalho de Conclusão de Curso, Circuitos Digitais, Automação e Robótica, Sistemas Microcontrolados, Projeto e Análise de Algoritmos (PAA)

\section{DULCE BARBOSA LINS}

Graduanda em ciências biológicas licenciatura pela universidade federal de Alagoas.

\section{EDNA FELIX DA SILVA}

Graduada em Pedagogia, Universidade Estadual Vale do Acaraú em 2010. Pós-graduada em Psicopedagogia pela faculdade Escritor Osmar Lins em 2011. Pós-graduanda em Pesquisas Avançadas (ALPHA) 2019. Mestrando ciências da educação (EAD-ATENAS) 2019.

\section{ERLANDO DA SILVA RESES}

Professor Associado da Faculdade de Educação (FE) da Universidade de Brasília (UnB) e Docente do Programa de Pós-Graduação em Educação (PPGE). Pós-doutorando na Universidade de Londres (SOAS-Faculdade de Estudos Orientais e Africanos) e Doutor em Sociologia com pesquisa na área de Sociologia do Trabalho e da Educação. Mestre em Sociologia com pesquisa na área de Sociologia no Ensino Médio. Bacharel em Sociologia com estudo na área de Sociologia Política e Licenciado em Ciências Sociais, todos os títulos pela Universidade de Brasília (UnB).Foi professor de Sociologia na Educação Básica na Secretaria de Educação do Distrito Federal (SEDF). Líder do Grupo de Estudos e Pesquisas sobre Materialismo Histórico-Dialético e Educação (CONSCIÊNCIA). Membro do Grupo de Estudos e Pesquisas sobre o Trabalho (GEPT) do Instituto de Ciências Sociais (ICS)/Departamento de Sociologia da UnB. Coordenador de Programas de Extensão de Democratização do Acesso à Educação Superior: FORMANCIPA (Formação Integrada e Emancipadora de Acesso à Educação Superior) e Pós-Populares - Democratização do Acesso à Universidade Pública pelo Chão da Pesquisa. Coordenador de Projeto de Extensão sobre Democratização do Acesso ao Livro e a Leitura (LeiA - Leitura e Ação Lúdico-Pedagógica com Crianças). Coordenador de Programa de Extensão sobre Preservação da Memória da Educação de Jovens e Adultos (Centro de Memória Viva Documentação e Referência em Educação de Jovens e Adultos, Educação Popular e Movimentos Sociais do DF). Tem experiência na área de Sociologia; Políticas Públicas de Educação; Currículo; Epistemologias; Formação de Professores; Educação de Jovens e Adultos; Educação Popular; Ensino de Sociologia; Ensino Médio; Metodologia da Pesquisa; Educação em Direitos Humanos, Educação em Prisões, Gênero, Raça e Classe. 


\section{EVELIN OLIVEIRA DE REZENDE PIZA}

Doutoranda pelo Programa de Pós-Graduação em Educação Escolar da Universidade Estadual Paulista "Júlio de Mesquita Filho" (FCLCAr/ UNESP/ Campus Araraquara), Mestre (2013) pelo Programa de Pós-Graduação em Educação Especial da Universidade Federal de São Carlos (UFSCar). Especialista em Educação Infantil, a Escola de Nove Anos, Pesquisas e Gestão Escolar (2011) pela Universidade Federal de São Carlos (UFSCar). Pedagoga (2008) pela Universidade Estadual Paulista Júlio de Mesquita Filho (FCLCAr/UNESP). Atuou na Tutoria Virtual no Curso de Licenciatura em Pedagogia na modalidade a distância da Universidade Aberta do Brasil - Universidade Federal de São Carlos (UAB/UFSCar), na Educação Infantil, como Professora orientadora de TCC de cursos de Especialização da UNIARA, como docente no Ensino Superior em outras instituições. Atualmente dedica-se a pesquisa referente ao doutorado. Tem experiência no Ensino Superior, na tutoria virtual, na Educação Infantil e nos Anos Iniciais do Ensino Fundamental de I Ciclo. Atua principalmente nas seguintes áreas de investigação: Educação especial; Transtorno do Espectro Autista; Formação de professores; cursos de Pedagogia; Políticas públicas.

\section{FÁBIO DIAS DE OLIVEIRA JUNIOR}

Graduação em Licenciatura em Química pela Fundação Técnico-Educacional Souza Marques (FTESM), em 2017.

\section{FERNANDA LIMA FERREIRA}

Graduanda em Ciências Biológicas Licenciatura pela Universidade Federal de Alagoas.

\section{FERNANDA VAZ TORRES}

Psicóloga formada pela UNIFACS (2019). Pós graduanda em Neuropsicologia e estudante de Pedagogia.

\section{FRANCISCA MARIA GOMES CABRAL SOARES}

Graduação em Pedagogia pela Universidade do Estado do Rio Grande do Norte (UERN), mestrado em Educação pela Universidade Federal do Rio Grande do Norte (UFRN), doutorado em Educação pela Universidade do Estado do Rio de Janeiro (UERJ). Líder do grupo de estudos e pesquisas Memórias, Auto(biografia) e Inclusão (GEPEMABI) . Atualmente é professora adjunto IV da UERN. Pró-Reitora Adjunto da Pró- Reitoria de Ensino de Graduação da UERN, pessquisadora institucional do Programa de Pós-Graduação em Educação (POSEDUC-UERN), coordenadora do GT 15 - Educação Especial da Regional Nordeste da ANPEd. Tem experiência na área de Educação, com ênfase em Educação, atuando principalmente nos seguintes temas: formação docente, educação inclusiva, prática pedagógica, autismo, linguagem, os processos de ensino e aprendizagem e alfabetização na infância.

\section{GABRIEL DOMINGOS CARVALHO}

Professor do Instituto Federal de Educação, Ciência e Tecnologia do Espírito Santo (Ifes - Campus Piúma), possui Graduação em Medicina Veterinária pela Universidade Federal do Espírito Santo (Ufes), Mestrado e Doutorado em Medicina Veterinária pela Universidade Federal de Viçosa (UFV). Especialista em Práticas Pedagógicas para Professores (Ifes) com aperfeiçoamento em Formação Docente para Educação a Distância (Ifes) e aperfeiçoamento em Inclusão e Educação Especial (Ifes). Atua na Rede Federal de Educação Profissional, Científica e Tecnológica há 10 anos e, no Ifes, além das suas atividades docentes, atua como Coordenador do Curso de Pós-Graduação em Controle de Qualidade e Segurança de Alimentos, e é membro do Núcleo de Atendimento a Pessoas com Necessidades Específicas - Napne e membro da Comissão Permanente de Ações Afirmativas na PósGraduação do Ifes. 


\section{GABRIELA DA SILVA SACCHELLI}

Possui graduação em Pedagogia e Sociologia. É especialista em Educação Especial pela ESAP, Especialista em Gestão Escolar pela UNICENTRO e Especialista em Mídias na Educação pela UNICENTRO. É Mestre em Educação pela UEM - Universidade Estadual de Maringá e participa do grupo de estudos e pesquisas História da Educação, Intelectuais e Instituições Escolares. Atualmente é Professora no Curso de Pedagogia na UNESPAR campus Apucarana e na FAP - Faculdade de Apucarana, onde também atua no Núcleo de Apoio Psicopedagógico.

\section{GEANY CARLA BARROS SILVA}

Graduada em Pedagogia na Faculdade da Escada-FAESC. Pós-graduada em recursos humanos pela Faculdade Joaquim Nabuco.Pós-graduanda em Pesquisas Avançadas (ALPHA) 2019. Mestrando ciências da educação (EAD-ATENAS) 2019.

\section{GENILDA MENDONÇA DE SOUZA ARAÚJO}

Graduada em Pedagogia e Geografia pela Universidade Estadual da Paraíba-UEPB(2019). Especialista em Ciências Ambientais pela FIP. Formação em Braille, tradução em braille pela FUNAD,e Educação especial e Inclusiva, pela SEAD-Secretaria de Apoio à Pessoa com deficiênca. Professora do município de Guarabira de braille.

\section{IVANI SOARES}

Mestre em Políticas Públicas e Gestão Educacional pela Universidade Federal de Santa Maria. Especialista em Direito Tributário e em Educação, Diversidade e Cidadania. Possui graduação em Letras (Português e Inglês - 1997) e graduação em Direito (2002), ambas pela Universidade Regional Integrada do Alto Uruguai e das Missões. É Revisora de Textos. Atualmente é Secretária Executiva da Universidade Federal do Pampa em atuação na Unidade de Auditoria Interna. É integrante do Grupo de Estudos e Pesquisa Dialogus: Educação, Formação e Humanização com Paulo Freire e dos Projetos de Extensão Hora do Conto: lendo o mundo e auto(trans)formando realidades e de Pesquisa: humanização e cidadania com professores.Tem experiência na área de Letras, com ênfase em Secretariado/Revisor de Texto, atuando principalmente nos seguintes temas: Educação de Jovens e Adultos, acesso e permanência no Ensino Superior, políticas públicas, pedagogia dialógica e auto(trans)formação.

\section{IZABELI SALES MATOS}

Mestra em Educação pelo Programa de Pós-Graduação em Educação da Universidade Estadual do Ceará (UECE). Educadora Física pela Universidade de Fortaleza (UNIFOR). Especialista em Atendimento Educacional Especializado (AEE) pela Universidade Federal do Ceará (UFC); em Formação de Professores na Área da Deficiência Visual pela Sociedade de Assistência aos Cegos; em Psicomotricidade pela Universidade Estadual do Ceará (UECE); e em Lazer pela Universidade Federal de Minas Gerais (UFMG). Docente da Associação de Cegos do Estado do Ceará (ACEC), no AEE e Orientação e Mobilidade. Docente do curso de Especialização em Orientação e Mobilidade do Instituto Federal de Educação, Ciências e Tecnologia do Ceará (IFCE), e do curso de Especialização em Orientação e Mobilidade pela Faculdade ALPHA (Recife - PE). 


\section{JORDANA LORENA NOGUEIRA DE SOUSA}

Graduada em Pedagogia pela Universidade do Estado do Rio Grande do Norte - UERN (2017.2), com estudos voltados para o Bilinguismo, como proposta para a educação de surdos.Especialista em Educação: diálogo entre as linguagens para a construção da cidadania /DE/FE/UERN. Mestranda do Programa de Pós-Graduação em Educação (POSEDUC) da Universidade do Estado do Rio Grande do Norte (UERN) - 2018.2. Intérprete da Língua Brasileira de Sinais - LIBRAS pela Diretoria de Políticas e Ações Inclusivas (DAIN) da Universidade do Estado do Rio Grande do Norte (UERN), turma 2017.2. Aluna Especial do mestrado do Programa de Pós-graduação em Educação (POSEDUC/UERN) , na disciplina Tópicos Especiais em Educação I : Gestão educacional e perspectivas epistemológicas contemporâneas (2018.1). Possuo experiência profissional na Educação Infantil/ Fundamental/Nível Superior e capacitação profissional na área da educação especial/inclusiva. Estudante no grupo de pesquisa Grupo de Estudos e Pesquisas em Educação, Memórias, (Auto) Biografias e Inclusão - GEPEMABI, da Universidade do Estado do Rio Grande do Norte (UERN). Supervisora Pedagógica SESI/RN

\section{JULIO CESAR MELLO D'AMATO}

Possui graduação em Psicologia pela Faculdade de Biologia e Psicologia Maria Theresa (1994), graduação em Direito pela Universidade Federal do Rio de Janeiro (1983), mestrado em Psicologia pela Universidade Federal do Rio de Janeiro (2003) e doutorado em Psicologia pela Universidade Federal do Rio de Janeiro (2006). Atualmente é técnico-administrativo da Universidade Federal Fluminense atuando na Divisão de Prevenção e Promoção da Saúde da Coordenação de Saúde e Qualidade de Vida. 'Professor adjunto da UNILASALLE RJ. Tem experiência na área de Psicologia, com ênfase em: Educação, Jurídica, Organizacional e Psicanálise.

\section{KALTIELI GOMES DA SILVA}

Graduada em Pedagogia pela Universidade Estadual Vale do Acaraú em 2012. Pós-graduanda em Psicopedagogia Clínica e Institucional pela FEPAM em 2014, Pós-graduanda em Pesquisas Avançadas (ALPHA) 2019. Mestrando ciências da educação (EAD-ATENAS) 2019

\section{LARISSA KELLY DOS SANTOS SILVA}

Graduanda em ciências biológicas licenciatura pela universidade federal de Alagoas

\section{LENILDA DAMASCENO PERPÉTUO}

Professora da Educação Básica da Secretaria Estadual de Educação do Distrito Federal, Mãe, Mulher trabalhadora, militante da Educação popular, pública transformadora e de qualidade, da Educação de Jovens e adultos (EJA), alfabetizadora popular, pesquisadora em acampamentos ciganos Calon, autora da dissertação sobre Processo de Escolarização da Comunidade Cigana Calon - publicada: http://repositorio.unb.br/handle/10482/31549. Sempre militando em defesa dos direitos humanos, diversidade, igualdade racial, causas relativas às lutas de classes, ao proletariado oprimido e as desigualdades sociais que infelizmente na nossa sociedade capitalista insiste em acentuar cada vez mais esse abismo social. Licenciada em Ciências Biológicas pela Universidade Estadual do Maranhão UEMA (1998), Especialista em docência do Ensino Superior , pela FENOM, , Instituto Prominas (2004), Especialista em Educação na Diversidade e Cidadania com Ênfase na Educação de Jovens e Adultos EJA pela Faculdade de Educação da UnB( 2014). Mestre em Educação pela Faculdade de Educação da Universidade de Brasília UnB(2017), na linha de Políticas Públicas POGE. doutoranda em Educação POGE pela UnB (2019), Pauto minha trajetória acreditando numa educação libertadora que emancipa os seus sujeitos e sujeitas e os retiram do lugar "comum" para a conquista de espaços de fortalecimentos, de fala e de escuta crítica consciente, numa perspectiva freireana onde a práxis e a dialética cumprem o seu papel no movimento. Durante minha vida profissional trabalhei em todos os níveis de Escolarização: Educação Infantil, Ensino Fundamental (anos iniciais e finais), Ensino Médio, Educação de Jovens e adultos EJA e Alfabetização de adultos trabalhadores. 


\section{LUCI PASTOR MANZOLI}

Mestrado em Educação Especial pela Universidade de Boston (Boston University - USA) e Doutorado em Educação pela Faculdade de Educação da Universidade de São Paulo - USP-SP. É professora assistente doutora na Faculdade de Ciências e Letras da Universidade Estadual Paulista Júlio de Mesquita Filho, Campus de Araraquara. Credenciada no Programa de Pós-Graduação em Educação Escolar (FCLAr/UNESP) como docente e orientadora. Líder do Grupo de Estudos e Pesquisa no Ensino Básico e Educação Especial. Atuou como professora do ensino fundamental 1a a 4⿳亠丷a série e também na área de Educação Especial. Desenvolve trabalhos com as temáticas: surdez, deficiência intelectual, aprendizagem de leitura e escrita, adaptação curricular, formação de professores e inclusão escolar.

\section{LUCIANE MARIA RIBEIRO DA CRUZ SANTOS}

Doutoranda em Educação pela Pontifícia Universidade Católica de Minas Gerais iniciado em 2017. Mestre em Educação pela Pontifícia Universidade Católica de Minas Gerais (2012). Participou do Grupo de Pesquisas Tecnologias Digitais em Educação entre 2010 e 2013. Especialista em Psicopedagogia e em Coordenação e Supervisão Pedagógica. Professora no Projeto de Leitura Palavras Livres do Presídio de Itabira desde 2014. Atuou como Secretária Municipal de Educação entre 2013 e 2016, período em que coordenou a execução do Programa Prefeito Amigo da Criança e coordenou e executou o programa de Capacitação de Professores e Gestores das escolas municipais. Participou da fundação do Território de Cooperação Educacional do Médio Piracicaba e atuou como presidente nos anos de 2015 e 2016. Atuou como orientadora acadêmica da Fundação Comunitária de Ensino Superior de Itabira, professor municipal da Prefeitura Municipal de Itabira. Coordenou o grupo de trabalho do Projeto Atitude Ambiental de 2010 a 2012. Tem atuando principalmente nos seguintes temas: formação e coordenação pedagógica de professores, educação ambiental, tecnologias digitais na educação, centros de custos de educação básica, investimento na escola e educação integral, gestão da educação.

\section{MÁRCIA GOMES DOS SANTOS SILVA}

Mestre em Ciências da Educação pela Universidad Autônoma de Assuncion (2016). Graduada em Pedagogia, tem experiência como Coordenadora Pedagógica da Educação Infantil e como professora de Educação Básica na rede pública e privada no município de Mogeiro. Especialista em Psicopedagogia com Ênfase na Docência, doutoranda em Ciências da Educação pela Universidad Autónoma de Asunción-PY. Experiência como Professora do Magistério Superior na Universidade Estadual da Paraíba- UEPB na área de Estágio Supervisionado e Fundamentos da Educação Infantil.

\section{MARCOS MAGALHÃES VASQUEZ}

Psicoterapeuta com especialização em fenomenologia existencial formado pela PUC-SP, neuropsicólogo clinico pós graduado pelo Instituto Lev Vygotsky. Atualmente trabalha com crianças com dificuldade em aprendizagem e adolescentes em orientação vocacional.

\section{MARIA JULIA PEDROSO}

Formada no ensino médio e técnico, na área de Química, pelo Instituto Federal de Santa Catarina Campus Gaspar. Discente do curso Licenciatura em Química na Universidade Federal de Santa Catarina, Brasil. Participou do grupo de pesquisa OPC - Observatório de Práticas Curriculares na UFSC - Blumenau, foi bolsista no projeto de extensão "Escola, Currículo e Tecnologias: integração didático-interdisciplinar sobre os usos de tecnologias nas práticas docentes", orientado por Alaim Souza Neto e participou do livro "Ensino de ciências, currículo e inclusão: diálogos interdisciplinares. 


\section{MARIA ROSEMARY DE BRITO}

Graduada em pedagogia, especialista em educação especial, mestranda em ciências da educação. Atua na Área da educação a 35 anos, atualmente é coordenadora de uma escola do campo no município de Ipojuca-PE.

\section{MELINA ROSA DA SILVEIRA FRANCO}

Possui graduação em Pedagogia (2006). Pós graduada em Psicopedagogia abordagem clínica dos problemas de aprendizagem (2008) e Práticas de alfabetização e Letramento (2010). Realizou trabalho de tutoria de cursos on-line pelo site Companhia da Educação. Atuou como Psicopedagoga Clínica de 2008 à 2013 e lecionou como professora de Educação Básica - Anos Iniciais do Ensino Fundamental durante o mesmo período. Em 2014 desenvolveu atividade profissional como vicediretora de escola. Trabalhou com Formação de Professores, sendo Coordenadora do Núcleo Pedagógico da Diretoria de Ensino - Região de Araraquara na área de Tecnologia. Atualmente é Diretora de Escola. Mestre pela Faculdade de Ciências e Letras da Universidade Estadual Paulista Júlio de Mesquita Filho, Campus de Araraquara sob orientação da Professora Doutora Luci Pastor Manzoli. Membro do Grupo de Estudos e Pesquisa no Ensino Básico e Educação Especial tendo como líder a Professora Doutora Luci Pastor Manzoli. Tem experiência na área de Educação, com ênfase em Educação.

\section{MÔNICA DE FÁTIMA GUEDES DE OLIVEIRA}

Doutoranda em Ciencias da Educação pela UAA_Universidade Autonoma de Assunção -PY. Mestre em Educação pela Universidade Federal da Paraíba. Especialista em Supervisão Escolar-UFPB. Graduada em História e Pedagogia -UFPB. Professora da Universidade Estadual da Paraíba do Departamento de Educação - $\mathrm{CH}$. Coordenadora Adjunta do Curso de Pedagogia da UEPBUniversidade Estadual da Paraíba, Campus III. Professora da Área de Instrumentação das Práticas Pedagógicas

\section{MÔNICA DE FÁTIMA GUEDES DEOLIVEIRA}

Doutoranda em Ciencias da Educação pela UAA_ Universidade Autonoma de Assunção -PY. Mestre em Educação pela Universidade Federal da Paraíba. Especialista em Supervisão Escolar-UFPB. Graduada em História e Pedagogia -UFPB. Professora da Universidade Estadual da Paraíba do Departamento de Educação - CH. Coordenadora Adjunta do Curso de Pedagogia da UEPBUniversidade Estadual da Paraíba, Campus III. Professora da Área de Instrumentação das Práticas Pedagógicas.

\section{MONIQUE GONÇALVES}

Doutoranda em Engenharia de Processos Químicos e Bioquímicos na Escola de Química (EQ) / UFRJ (2018). Mestre em Química pelo Departamento de Química Orgânica do Instituto de Química da UFRJ (2007). Pós-graduação Lato Sensu em Educação Especial e Inclusiva (2019). Especialização em "Processos de Escolarização de Alunos com Necessidades Educacionais Especiais" (2018). Graduação em Química pelo IQ / UFRJ (2004) e Licenciatura em Química pelo IQ/UFRJ (2005). Experiência na área de Química, com ênfase em Química Orgânica, atuando principalmente nos seguintes temas: Planejamento e desenvolvimento de pesquisa de novos compostos orgânicos, incluindo novos fármacos com potencial atividade biológica. Atualmente é docente em Química no Instituto Superior de Educação do Rio de Janeiro (ISERJ), concursada 40h, a partir de fevereiro de 2014, regime ESTATUTÁRIO. Docente no Ensino Superior na Fundação Técnico Educacional Souza Marques (FTESM), a partir de setembro de 2010, nas disciplinas Análise Orgânica, Química Orgânica I, III e IV. Professora de química no Colégio Cruzeiro Centro, a partir de fevereiro de 2015. 


\section{NAHYME ZAHIA AMARAL MOHANA}

Bacharel em Ciências Econômicas - Universidade da Amazônia - Belém-PA -1991 Especialização Lato-Sensu em Biodiesel - das Oleaginosas, à produção e análise - Avaliação do Potencial da Pupunheira para a Produção de Biodiesel - IF Goiano - Campus Morrinhos - 2008/2009 Mestranda pela Universidade Federal Rural do Rio de Janeiro, UFRRJ, Brasil. Título: Políticas Públicas de Educação Inclusiva: Desafios à Escolarização Profissional do PúblicoAlvo da Educação Especial do IF Goiano - 2018, em andamento Servidora Pública Federal, lotada no Instituto Federal de Educação, Ciência e Tecnologia Goiano Goiânia-GO. Coordenadora de Execução Orçamentária e Financeira Substituta, lotada na PróReitoria de Administração.

\section{NEUSA APARECIDA MENDES}

Doutora e Mestre em Educação Escolar pela Universidade Estadual Paulista - UNESP - Campus de Araraquara (2014), especialista em Pedagogia do Movimento pela Universidade Estadual de Campinas - UNICAMP (2002) e licenciada em Educação Física pela Pontifícia Universidade Católica de Campinas - PUCCAMP (1996). Atualmente é PEB II - Educação Física do Governo do Estado de São Paulo e Tutora semipresencial na Faculdade Anhanguera. Tem experiência na área de Educação Física, com ênfase em Educação Física Escolar, Educação Física Adaptada, atuando principalmente nos seguintes temas: educação física escolar, educação inclusiva, educação a distância - EAD e gestão educacional.

\section{NICOLY LONGARETTI DE SOUZA}

Discente do curso Licenciatura em Matemática na Universidade Federal de Santa Catarina. Participou do grupo de pesquisa OPC - Observatório de Práticas Curriculares na UFSC - Blumenau, foi bolsista no projeto de extensão "Escola, Currículo e Tecnologias: integração didáticointerdisciplinar sobre os usos de tecnologias nas práticas docentes", ambos com orientação do Prof. Dr. Alaim Souza Neto.

\section{OZINALDO OLIVEIRA DOS SANTOS}

1. Mestre em Saúde Pública. USP. 2003. 2. Doutor em Saúde Pública. USP. 2013. 3.Prof. Doutor e Pesquisador. UFAL. 1993 a 2020.

\section{PRISCILA FIGUEIREDO BRITO DE AZEVEDO}

Licenciatura e Bacharelado em Educação Física pela Universidade Paranaense. Mestranda em Educação pela Universidade do Estado do Rio Grande do Norte. Participou como estagiária entre 2005 a 2008 no Projeto Recreação e Lazer da Universidade Paranaense - Unipar. Atuou como estagiária 2006 a 2008 no Projeto Dançaterapia para terceira idade da Universidade Paranaense Unipar . Foi atleta profissional de Voleibol pelo BCN Osasco, Seleção Paranaense . Atuou no NUPEA da Faculdade Nova Esperança de Mossoró- FACENE/RN. Idealizadora e Personal da Overall Training. Certificação em Levantamento de Peso Olímpico pela Faculdade de Educação Física do Exército Brasileiro - RJ. Certificação na Metodologia CORE 360 1,2,3 e 4. Certificação em treinamento para cadeirantes pelo CORE 360. Personal Trainner para grupos especiais. Formação em Crossfit e Gymnastics. Atuou como Educadora Física da Clínica Cardiológica de Mossoró 2014 a 2015. Atua no Núcleo de Pesquisa e Desenvolvimento do Colégio Mater Christi com experiencia na área de Educação, com ênfase em Educação , atuando nos seguintes temas: gestão, formação docente, desenvolvimento de projetos inovadores para Educação do Século XXI, educação inclusiva, práticas pedagógicas ,psicomotricidade, esporte e educação física 


\section{RENATA GANDRA DE MELO}

Mestranda em Educação Profissional e Tecnológica pelo Instituto Federal de Educação, Ciência e Tecnologia do Espírito Santo (Ifes), a autora é Assessora Pedagógica na Diretoria de Pós-graduação da Pró-reitoria de Pesquisa e Pós-graduação, Reitoria, do Ifes. Recentemente tem adquirido experiência em gestão de projetos e políticas públicas educacionais, implantação de políticas afirmativas e inclusão.

\section{ROSEMEIRE QUILANTE AZEVEDO}

Pedagoga formada pela Faculdade Campos Salles, psicopedagoga clínica formada pela PUC - SP, Professora Mediadora do Programa de Enriquecimento Instrumental de Reuven Feuerstein, mestranda de fonoaudiologia pela PUC - SP e professora de Atendimento Educacional Especializado - AEE.

\section{SIMONE GARRIDO ESTEVES CABRAL}

Doutora em Letras - Estudos de Literatura pela PUC-Rio (2010); Mestrado em Letras - Estudos de Literatura pela Pontifícia Universidade Católica do Rio de Janeiro (2004) e Graduação em Letras Português Literaturas - pela Universidade Federal do Rio de Janeiro (1987). Atualmente é professor titular - Centro Universitário La Salle - UNILASALLE-RJ, professor docente dos cursos de Pedagogia e Ciências Contábeis, Administração e Sistemas de Informação; Instituto Maia Vinagre, Coordenadora do EF II e do EM; Secretaria de Estado de Educação, professor docente, coordenadora do EM, diretora adjunta, aposentada. Tem experiência na área de Letras, Pedagogia e demais cursos de graduação com ênfase em Literatura Brasileira, Leitura e Produção de Textos e Língua Portuguesa, atuando principalmente nos seguintes temas: literatura, língua portuguesa, alfabetização e letramento e metodologia.

\section{SUZANA ARLENO SOUZA SANTOS}

Possui graduação em Física pela Universidade Federal de Sergipe, mestrado em Ciências dos Materiais pelo Instituto Militar de Engenharia (2011) e doutorado em Ciências dos Materiais pelo Instituto Militar de Engenharia (2015). Atualmente é professor horista da Universidade Estácio de Sá, professor horista da Universidade Veiga de Almeida, professor horista da Universidade Castelo Branco e professor horista do Centro Universitário La Salle - Niterói. Tem experiência na área de Física, com ênfase em Física, atuando principalmente nos seguintes temas: sol-gel, ciências dos materiais, bioplásticos,, comportamento mecânico e carbeto de silicio.

\section{WALACE ROZA PINEL}

Mestre e Doutorando em Educação pela Universidade de Brasília na linha de pesquisa em Políticas Públicas e Gestão da Educação. Atualmente professor de Educação Básica na Secretaria de Estado de Educação do DF. Especialista em Psicopedagogia e Licenciado em Pedagogia. Pesquisador do Grupo de Pesquisas (CAPES/CNPq) Consciência e Pós-Populares - Democratização do Acesso à Universidade Pública pelo Chão da Pesquisa (FE/UnB). Foi professor EBTT no Instituto Federal de Goias em 2018. Foi bolsista CAPES/CNPq no Proeja-Transiarte em 2016 junto ao IFB - São Sebastião. Professor Tutor em EaD no IFB nos anos de 2017 e 2018 atuando junto ao PRONATEC; Professor Tutor na UniLasalle do curso de Pedagogia em 2018. Professor nos cursos de Pedagogia, Administração na FASOL em 2019. Tem experiência em: EaD; Educação Profissional; Educação de Jovens e Adultos; Educação em Prisões; Educação Popular; Materialismo Histórico Dialético; Metodologia da Pesquisa; Educação e Trabalho; e Educação em Direitos Humanos. 


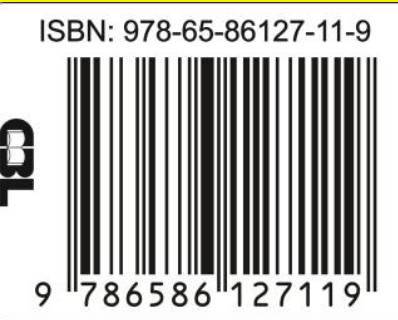

